Manuela Grill Rodrigues

Juventudes e Escolas: clima escolar, mobilização, participação e autoeficácia

Dissertação de Mestrado

Dissertação de mestrado apresentada como requisito parcial para obtenção do grau de Mestre em Educação pelo programa de Pós-graduação em Educação, do Departamento de Educação da PUCRio.

Orientadora: Cynthia Paes de Carvalho Co-orientadora: Karina Carrasqueira 


\title{
Manuela Grill Rodrigues
}

\author{
"Juventudes e Escolas: clima escolar, \\ mobilização, participação e \\ autoeficácia"
}

Dissertação apresentada como requisito parcial para obtenção do grau de Mestre pelo Programa de Pós-graduação em Educação do Departamento de Educação do Centro de Teologia e Ciências Humanas da PUC-Rio. Aprovada pela Comissão Examinadora abaixo assinada.

Prof ${ }^{a}$. Cynthia Paes de Carvalho

Orientadora

Departamento de Educação - PUC-Rio

Profa. Karina Carrasqueira Lopes

Co-orientadora

Departamento de Educação - PUC-Rio

Profa. Ana Cristina Prado de Oliveira

UNIRIO

Prof. Pedro Pinheiro Teixeira

Departamento de Educação - PUC-Rio

Profa. Monah Winograd

Coordenadora Setorial do

Centro de Teologia e Ciências

Humanas

PUC-Rio 
Rio de Janeiro, 18 de fevereiro de 2021. Todos os direitos reservados. É proibida a reprodução total ou parcial do trabalho sem autorização da universidade, da autora e do orientador.

\section{Manuela Grill Rodrigues}

Graduou-se em Pedagogia pela Universidade Federal do Rio de Janeiro (UFRJ) em 2018. Durante a graduação atuou no Laboratório de Estudos e Pesquisas em Educação Superior (LEPES), investigando evasão e permanência no ensino superior. Na PUC-Rio, integra o grupo de pesquisa Gestão e Qualidade na Educação (GESQ), coordenado pela Prof. Cynthia Paes de Carvalho. Interessa-se pelos temas de democratização da educação, políticas educacionais, gestão educacional e gestão escolar.

Ficha Catalográfica

Rodrigues, Manuela Grill

Juventudes e escolas: clima escolar, mobilização, participação e autoeficácia / Manuela Grill Rodrigues; orientadora: Cynthia Paes de Carvalho; co-orientadora: Karina Carrasqueira. - 2021. $180 \mathrm{f.} ; 30 \mathrm{~cm}$

Dissertação (mestrado) - Pontifícia Universidade Católica do Rio de Janeiro, Departamento de Educação, 2021.

Inclui bibliografia

1. Educação - Teses. 2. Juventude. 3. Escola. 4. Clima escolar. 5. Participação. 6. Autoeficácia. I. Carvalho, Cynthia Paes de. II. Carrasqueira, Karina. III. Pontifícia Universidade Católica do Rio de Janeiro. Departamento de Educação. IV. Título. 


\section{Agradecimentos}

Primeiramente, agradeço à minha orientadora, Cynthia Paes de Carvalho, pela parceria e pelos ensinamentos nos últimos dois anos. Sou grata pelas oportunidades concedidas e que foram de fundamental importância para o meu crescimento acadêmico e pessoal. Agradeço também à minha co-orientadora, Karina Carrasqueira Lopes, por todo tempo e ajuda disponibilizada, além das ricas contribuições que foram essenciais para a realização deste trabalho.

Aos professores, Ana Cristina Prado de Oliveira, Pedro Pinheiro Teixeira e Naira da Costa Muylart Lima, por contribuírem de forma significativa com este estudo desde a qualificação do projeto de pesquisa até a defesa. Agradeço também à professora Prof ${ }^{a}$ Eliane Ribeiro de Andrade pelo tempo dedicado à leitura deste trabalho.

À CAPES, FAPERJ e PUC- Rio, pelos auxílios concedidos para a realização desta pesquisa.

Ao GESQ, grupo de pesquisa que me acolheu com tanto carinho e que contribuiu de tantas formas para a realização deste trabalho. Em especial, ao colega João Carlos Gino, pela disposição em ajudar a realizar o trabalho de campo desta pesquisa.

Aos jovens maranhenses e cariocas que concordaram em participar deste estudo em meio a uma pandemia mundial. Sem vocês nada disso seria possível!

À minha família que, mais uma vez, me concedeu todo apoio e amparo emocional para seguir meus sonhos e concluir a minha jornada acadêmica na PUC-Rio. Ao meu companheiro, Leonardo, por ser meu porto seguro no Rio de Janeiro e por estar ao meu lado nos momentos que mais precisei. E, por fim, à Clara Bousada, amiga com quem compartilhei todas as angústias e vitórias ao longo desses dois anos e que foi um dos melhores encontros que o mestrado me proporcionou. 


\section{Resumo}

Rodrigues, Manuela Grill; Paes de Carvalho, Cynthia; Carrasqueira, Karina. Juventudes e escolas: clima escolar, mobilização, participação e autoeficácia. Rio de Janeiro, 2021. p. 177. Dissertação de Mestrado Departamento de Educação, Pontifícia Universidade Católica do Rio de Janeiro.

Tendo em vista a literatura que discute os desafios enfrentados pelos jovens ao longo da sua trajetória escolar e a influência de determinadas características instituicionais no enfrentamento dessas adversidades, o presente estudo busca conhecer quais as relações que os jovens de escolas públicas e privadas estabelecem com sua escola e com o seu processo de escolarização. Para isso, construímos um questionário com itens que buscavam mensurar a mobilização dos jovens em relação à escola e para a aprendizagem, as suas percepções sobre o clima escolar e a participação discente e, por fim, as suas crenças de autoeficácia acadêmica. $\mathrm{O}$ instrumento foi testado e aplicado a uma amostra de 224 jovens de $9^{\circ}$ ano do Ensino Fundamental de duas escolas públicas e três escolas privadas localizadas em São Luís (MA) e no Rio de Janeiro (RJ). Posteriormente, o instrumento foi validado a partir da construção de índices que buscaram mensurar alguns aspectos da escola na visão dos jovens. Os resultados do estudo apontam que os alunos das escolas privadas presentes em nossa amostra percebem um clima mais positivo nas suas escolas em quase todas as dimensões analisadas e possuem níveis mais altos de autoeficácia. Por outro lado, os jovens das escolas públicas se sentem mais mobilizados para irem à escola pela aprendizagem e acreditam que participam mais das decisões da escola. Por fim, discute-se até que ponto essas diferenças de percepções encontradas podem interferir na trajetória escolar e de vida dos jovens pesquisados.

Palavras-chave: juventude; escola; clima escolar; participação; autoeficácia. 


\begin{abstract}
Rodrigues, Manuela Grill; Paes de Carvalho, Cynthia; Carrasqueira, Karina. Youth and schools: school climate, mobilization, participation and selfefficacy. Rio de Janeiro, 2021. p. 177. Dissertação de Mestrado Departamento de Educação, Pontifícia Universidade Católica do Rio de Janeiro.
\end{abstract}

Considering the literature that discusses about the challenges faced by adolescents throughout their school life and the influence of some institutional characteristics facing these adversities, this study seeks to understand which relations public and private school students have with their schools and their schooling process. Therefore, we developed a questionnaire with items that could measure the mobilization of youngsters in relation to the school and for learning, such as their perceptions about school climate, student participation and, finally, their beliefs of academic self-efficacy. The questionnaire was tested and applied to a sample of 224 students of the $9^{\text {th }}$ year of schooling from São Luís (MA) and Rio de Janeiro (RJ) from public and private schools. Subsequently, the instrument was validated from the development of indexes that measured some school aspects from the students' point of view. The results indicate that the private school students who participated in this study perceive a more positive school climate in almost all analyzed dimensions and have higher levels of self-efficacy. On the other hand, the public school students feel more motivated to go to school due to the learning process and believe they play a more important role in the school decisions. In conclusion, it is discussed how far these differences in perception can interfere in school trajectory and in personal life of the surveyed students.

Key-words: youth; school; school environment; participation; self-efficacy. 


\section{Sumário}

1 - Introdução.......................................................................................................................... 15

2 -A juventude e os jovens brasileiros ................................................................ 19

2.1 - Juventude ou Juventudes? As perspectivas sociológicas sobre o tema .. 20

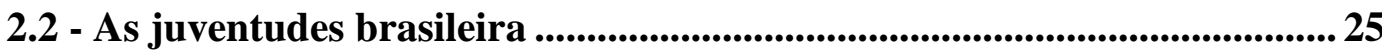

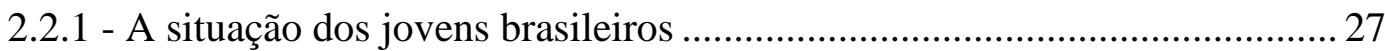

2.3. - Os desafios à escolarização ............................................................................... 34

3 - Os jovens no ambiente escolar: clima escolar, participação discente e autoeficácia............................................................................................................ 38

3.1 - Juventude e Clima Escolar ................................................................................. 38

3.1.1 - As pesquisas brasileiras sobre clima escolar............................................ 40

3.1.2 - Os estudos internacionais sobre clima escolar ....................................... 44

3.2 - Juventude e Participação...................................................................................... 49

3.2.1 - Os estudos brasileiros sobre juventude e participação.............................. 49

3.2.2 - Os estudos internacionais sobre juventude e participação ......................... 54

3.4 - Juventude e Autoeficácia ...........................................................................56

3.4.1 - Os estudos sobre autoeficácia e juventude no Brasil ............................... 58

3.4.2 - Os estudos internacionais sobre autoeficácia e juventude ........................ 60

4 - A construção do questionário "Jovens e escolas: quais as relações?" ......62

4.1 - Os questionários já existentes sobre juventude e escola ............................ 64

4.2 - Procedimentos metodológicos para a construção de um novo questionário

66

4.2.1 - Identificação dos conceitos primários e secundários e sua operacionalização 66

4.2.2 Especificação dos itens que irão compor o questionário. 69

4.3- Validação do instrumento................................................................................ 79

4.3.1- A validação dos pares - Grupo de pesquisa .............................................. 80

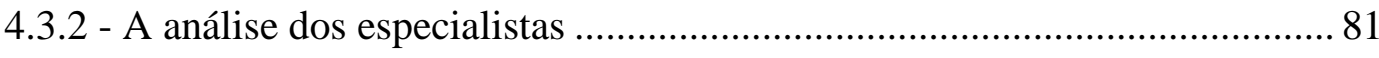


5 - Os caminhos de pesquisa em meio a pandemia da covid 19 ......................... 85

5.1 - A escolha dos jovens e das escolas .............................................................. 85

5.2 - Os desafios na aplicação do questionário no contexto da pandemia ...... 87

5.2.1 - Os jovens e as escolas em São Luís do Maranhão .................................... 89

5.2.2- Os jovens e a escola no Rio de Janeiro (RJ) ............................................. 93

5.3 - A Validação empírica do questionário ..................................................... 94

5.3.1 - Índices de mobilização em relação à escola.............................................. 96

5.3.2 - Índices que compõem a medida de clima escolar .................................... 99

5.3.3 - Índice de participação discente ............................................................. 104

5.3.4 - Índices de autoeficácia dos jovens....................................................... 105

6 - O que dizem os jovens sobre as suas escolas................................................... 108

6.1 - Perfil dos participantes ......................................................................................... 109

6.1.1 - Indicadores sociais e econômicos dos jovens pesquisados ...................... 109

6.1.2 - Os jovens e as suas trajetórias escolares............................................... 113

6.1.3 - Outros tipos de atividades realizadas pelos jovens .............................. 117

6.2 - A mobilização dos alunos em relação à escola e a importância do que

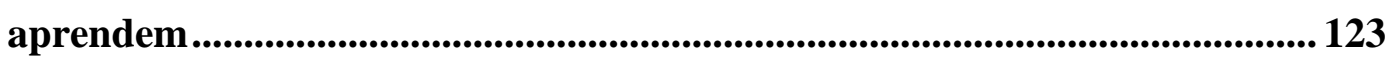

6.3 - A percepção dos jovens sobre o clima escolar ......................................127

6.3.1 - A percepção dos jovens sobre a dimensão infraestrutura ........................ 127

6.3.2 - A percepção dos jovens sobre as relações interpessoais do ambiente escolar 128

6.3.3 - A percepção dos jovens sobre o clima acadêmico 131

6.3.4 - A percepção dos jovens sobre o bullying e a discriminação no ambiente escolar 134

6.3.5 - Percepção dos jovens sobre a regras e sanções da escola 137

6.3.6 - O sentimento de pertencimento dos jovens em relação ao ambiente escolar 138 
6.4 - A percepção dos alunos sobre a participação discente no espaço escolar 140

6.5 - Crenças de autoeficácia dos jovens participantes da pesquisa 144

7- Considerações Finais............................................................................. 148

8 - Referências bibliográficas.............................................................................. 153 


\section{Lista de quadros}

Quadro 1 - Temas, conceitos e suas classificações ...............................68

Quadro 2 - Relação com a escola e com a aprendizagem: especificação

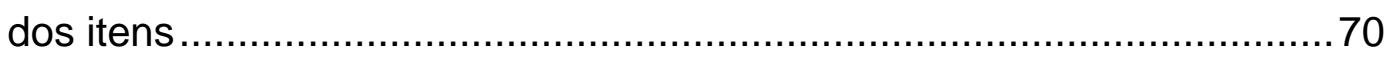

Quadro 3 - Clima escolar: especificação dos conceitos secundários .......71

Quadro 4 - Participação: especificação dos conceitos secundários ..........74

Quadro 5 - Autoeficácia: especificação dos conceitos secundários .........75

Quadro 6 - Hábitos juvenis: especificação dos conceitos secundários ....76 Quadro 7 - Caracterização sociodemográfica: especificação dos conceitos

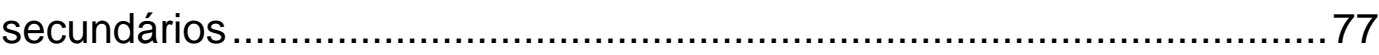

Quadro 8 - Índice de percepção dos alunos sobre as relações interpessoais no espaço escolar. 168

Quadro 9 - Índice de percepção dos alunos sobre a segurança física e emocional na escola. 168

Quadro 10 - Valores para categorização do Índice de mobilização em relação à escola. 169

Quadro 11 - Valores para categorização das dimensões do Clima Escolar

Quadro 12: Valores para categorização da percepção dos alunos sobre a participação discente no espaço escolar. 169 Quadro 13: Valores para categorização das crenças de autoeficácia do jovens. 169

Quadro 14 - Respostas do item "Na sua opinião qual o grau de importância do que você aprende por dependência administrativa. 170 


\section{Lista de Tabelas}

Tabela 1 - Resultado da análise fatorial e do teste de confiabilidade interna para o índice de mobilização do aluno para a aprendizagem.

Tabela 2: Resultado da análise fatorial e do teste de confiabilidade interna para o Índice de mobilização do aluno para projetos futuros.

Tabela 3: Resultado da análise fatorial e do teste de confiabilidade interna para o índice de mobilização do aluno para socialização. 99

Tabela 4: Resultado da análise fatorial e do teste de confiabilidade interna para o índice de percepção dos alunos sobre a infraestrutura 100

Tabela 5: Resultado a análise fatorial e do teste de confiabilidade interna para o Índice de percepção dos alunos sobre o compromisso do professor com a aprendizagem. 101

Tabela 6: Resultado da análise fatorial e do teste de confiabilidade interna para o índice de indisciplina em sala de aula. 102

Tabela 7: Resultado a análise fatorial e do teste de confiabilidade interna para o índice de percepção dos alunos sobre a sua relação de pertencimento ao espaço escolar.

Tabela 8: Resultado a análise fatorial e do teste de confiabilidade interna para o Índice de percepção dos alunos sobre as regras da escola. 103 Tabela 9: Resultado a análise fatorial e do teste de confiabilidade interna para o Índice de participação discente na vida escolar. 104

Tabela 10: Resultado a análise fatorial e do teste de confiabilidade interna para o Índice de autoeficácia acadêmica dos alunos. 105

Tabela 11: Resultado a análise fatorial e do teste de confiabilidade interna para o Índice de autoeficácia para cooperação escolar. 106

Tabela 12 - Mobilização dos jovens participantes em relação à escola 124 Tabela 13 - Percepção dos jovens sobre a infraestrutura da escola .....128 Tabela 14 - Percepção dos jovens sobre o compromisso dos professores com a aprendizagem

Tabela 15 - Percepção dos jovens sobre o clima disciplinar da sala de aula 
Tabela 16 - Percepção dos jovens sobre a justiça e clareza das regras e sanções

Tabela 17 - Nível de pertencimento dos alunos em relação às suas escolas 139

Tabela 18 - Percepção dos alunos sobre o nível de participação discente

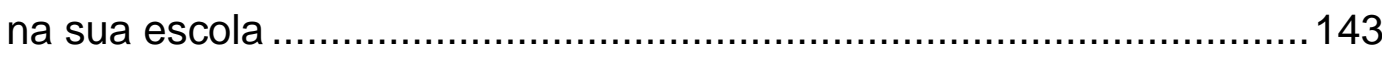

Tabela 19 - Nível de autoeficácia dos jovens por tipo de instituição .....145 


\section{Lista de gráficos}

Gráfico 1 - Percentual da população de 15 a 17 anos de idade que frequentava o Ensino Médio ou havia concluído a educação básica, por Brasil e grande região - 2012 - 2019 30 Gráfico 2 - Percentual da população de 15 a 17 anos de idade que frequentava o Ensino Médio ou havia concluído a educação básica, por sexo - Brasil - 2012 -2019

Gráfico 3 - Percentual da população de 15 a 17 anos de idade que frequentava o Ensino Médio ou havia concluído a educação básica, por cor/raça - Brasil - 2012 -2019.

Gráfico 4 - Sexo dos jovens participantes 110

Gráfico 5 - Cor/raça dos jovens participantes 111

Gráfico 6 - Escolaridade das mães dos jovens participantes. 112

Gráfico 7 - Situação de trabalho dos jovens participantes. 113

Gráfico 8 - Início da escolarização dos jovens participantes 114

Gráfico 9 - Pausa nos estudos pelos jovens participantes 115

Gráfico 10 - Histórico de reprovação dos jovens pesquisados 115

Gráfico 11 - O que os jovens pretendem fazer após terminar o $9^{\circ}$ ano 116 Gráfico 12 - O que os jovens da pesquisa se imaginam fazendo em 5 anos.

Gráfico 13 - Frequência que os jovens leem livros em geral 118

Gráfico 14 - Tempo de realização de tarefas doméstica pelos jovens ..119 Gráfico 15 - Tipos de participação social exercida pelos jovens

Gráfico 16 - Frequência em que os alunos são incentivados a participarem de ações fora da escola (projetos sociais, trabalhos em ONG'S, movimentos sociais).

Gráfico 17 - Percepção dos jovens das escolas privadas sobre a qualidade das relações interpessoais 129

Gráfico 18 - Percepção dos jovens das escolas públicas sobre a qualidade das relações interpessoais 129

Gráfico 19 - Eu nunca presenciei situações de discriminação na escola 
Gráfico 20 - Eu nunca presenciei situações de bullying na minha escola 135

Gráfico 21 - Os alunos devem participar das decisões da escola que dizem respeito a eles?

Gráfico 22- Opinião dos jovens sobre o seu nível participação nas decisões da escola que dizem respeito a eles.

Gráfico 23 - Existe grêmio estudantil ou outras formas de participação estudantil na sua escola? 142

Gráfico 24 - Percepção dos alunos sobre a sua capacidade de pensar em soluções para os problemas da escola 
1.

\section{Introdução}

A definição do termo "juventude" é um debate que permeia diversas áreas de conhecimento e que permanece em disputa em diferentes campos, como os da Saúde, Antropologia, Psicologia Social e Sociologia. A diversidade de abordagens e as diferentes conceituações em relação a um único termo aponta para a complexidade do tema. De acordo com Pereira (2009), a dificuldade na definição do conceito é justificada pelo fato do próprio objeto ser instável e descontínuo. A juventude está sempre em mudança, dependendo do contexto, do tempo e do local em que está situada, sendo, portanto, uma categoria em constante transformação.

Dias e Souza (2015) apontam que uma grande mudança na compreensão da juventude foi ocasionada pelo alvorecer da instituição escolar nas sociedades europeias, entre os séculos XV e XVII. De acordo com os autores, a partir da presença da juventude na escola, a família deixa de ter um controle hegemônico sobre a formação dos jovens e eles passam a ter mais contato com outras culturas, fortalecendo o surgimento de grupos juvenis que funcionavam como ponte para o desenvolvimento da autonomia do jovem na sociedade e promovia a sua independência diante da família. Contudo, até o século XIX, a escolarização foi privilégio somente para uma parte dos jovens pertencentes a classe burguesa e, apenas a partir do século XX, a escola passa a abranger os demais segmentos sociais e a ter um papel importante na formação dos jovens do continente europeu. No Brasil, esse processo ainda foi mais lento e as camadas mais populares só passaram a estar mais presentes no espaço escolar recentemente, com a expansão da escolarização na década de 1990.

Atualmente, quando falamos de juventude no Brasil, a instituição escolar possui um papel central na compreensão desse grupo etário, tendo em vista que boa parte do tempo da juventude é vivido dentro do espaço escolar. Todavia, a expansão tardia da escolarização e os desafios presentes em um país com enorme desigualdade social fazem com que a permanência com qualidade desse grupo no espaço escolar ainda seja um desafio. Os índices educacionais dos anos finais do Ensino Fundamental e do Ensino Médio, assim como a literatura que discute a trajetória escolar dos jovens brasileiros, apontam os obstáculos ainda presentes quando falamos sobre juventude e escola. No que se refere aos índices educacionais 
das etapas que abrangem a população juvenil do nosso país, os dados divulgados pelo Instituto Nacional de Pesquisas Educacionais Anísio Teixeira (INEP) apontam que a taxa de evasão escolar dos alunos matriculados na primeira série do ensino médio entre 2014 e 2015 foi de 12,7\% e 12,1\% dos matriculados na segunda série do mesmo segmento (BRASIL, 2017). Em relação a aprendizagem, os resultados da Prova Brasil ${ }^{1}$ de 2017 apontam que apenas 1,62\% dos estudantes da última série do Ensino Médio alcançaram níveis de aprendizagem considerados adequados na avaliação de Língua Portuguesa (BRASIL, 2019a).

Os resultados do segundo segmento do ensino fundamental também apresentam desafios. Os dados do Censo da Educação Básica de 2018 apontam que as maiores taxas de distorção idade-série estão no $6^{\circ}, 7^{\circ}$ e $8^{\circ}$ ano: $29,2 \%, 29,6 \%$ e 27\%, respectivamente (BRASIL, 2019b). Em relação a aprendizagem, de acordo com os resultados da Prova Brasil, $81,4 \%$ dos alunos do $9^{\circ}$ ano alcançaram o nível básico ou insuficiente ${ }^{2}$ na avaliação de Matemática. Em Língua Portuguesa, os resultados foram um pouco melhores, mas ainda preocupantes: apenas 39,6\% dos alunos alcançaram um nível adequado de aprendizagem (BRASIL, 2019a).

Esses índices e a literatura que trata dos desafios que os jovens enfrentam para continuidade e prolongamento da trajetória escolar, revelam a necessidade de compreender melhor as relações da juventude com as escolas. Pesquisas no campo da Sociologia da Educação, realizadas desde a década de 1960, apontavam a origem socioeconômica como fator determinante para a trajetória escolar dos jovens estudantes. Nesse cenário, as relações que os jovens estabelecem com as escolas seriam marcadas, fundamentalmente, por sua origem socioeconômica, em detrimento das características das instituições escolares.

Em contrapartida, a partir dos anos 1970, novos estudos, identificados como pesquisas sobre eficácia escolar, surgem para confrontar os estudos anteriores e afirmar que a escola também tem um peso importante no sucesso ou fracasso escolar dos alunos (BROOKE e SOARES, 2008; SAMMONS, 1999 e RUTTER et al. 1979). Autores do campo da eficácia escolar afirmam que existem fatores intraescolares que fazem diferença nas trajetórias dos alunos e que podem

\footnotetext{
1 Avaliação censitária, em larga escala, aplicada no último ano de cada segmento do Ensino Fundamental $\left(5^{\circ}\right.$ e $9^{\circ}$ ano) e, desde 2017, também no último ano do Ensino Médio $\left(3^{\circ}\right.$ ano $)$, com o objetivo de avaliar a qualidade do ensino oferecido pelo sistema educacional brasileiro. (fonte: http://portal.mec.gov.br/prova-brasil).

${ }^{2}$ Classificação qualitativa definida por SOARES (2009) com base na escala do SAEB.
} 
minimizar as desigualdades extraescolares. A partir dessas pesquisas, as práticas de ensino na sala de aula e as políticas específicas dos estabelecimentos escolares começaram a ser mais valorizados nas pesquisas educacionais, como parte do esforço para entender o que se passa dentro da escola e a influência desses fatores na trajetória dos alunos. Considerando esses estudos, a presente pesquisa entende que as práticas existentes no ambiente escolar interferem na forma como os grupos experienciam suas trajetórias escolares e influenciam sua permanência com qualidade.

Tomando como base as considerações destacadas até aqui, o principal objetivo deste estudo é, a partir da construção e aplicação de um questionário destinado aos alunos, compreender as relações que os jovens estabelecem com a escola e seu processo de escolarização. Nesse sentido, nos interessa conhecer como os jovens se mobilizam para ir à escola e aprender, quais são as suas percepções sobre os diferentes aspectos da sua escola, como avaliam as suas capacidades de executar tarefas dentro do espaço escolar e se existem diferenças nas relações que os jovens de escolas públicas e privadas estabelecem com a escola. Para responder a essas questões, além desta introdução, o trabalho contempla outros cinco capítulos. No capítulo 2, apresentamos uma breve revisão das teorias da juventude dentro do campo da Sociologia a partir da visão de Luís Antonio Groppo (2017) e, em seguida, fazemos uma análise da juventude brasileira a partir dos dados da PNAD (Pesquisa Nacional por Amostra de Domicílios) do ano 2019 e da literatura brasileira que trata dos desafios da juventude à escolarização (CHARLOT, 1996; TOMAZETTI et al., 2011; DAYRELL, REIS e LEÃO, 2011; PEREIRA e LOPES, 2016 e outros).

A partir da revisão de literatura sobre juventude e escola no Brasil, foi possível perceber que o clima escolar, a participação discente e a autoeficácia apareciam como importantes componentes para pensar a trajetória escolar dos jovens e a relação que eles estabelecem com as instituições. Sendo assim, no capítulo 3, apresentamos uma revisão dos estudos nacionais e internacionais publicados nos últimos anos sobre os três temas (clima escolar, participação discente e autoeficácia) e como eles se relacionam com a experiência escolar da juventude. Alguns dos estudos apresentados apontam que há relações significativas entre esses aspectos e o desenvolvimento cognitivo e socioemocional dos alunos no espaço escolar (CANDIAN e RESENDE, 2012ab; MELO e MORAIS, 2019; 
KLEIN, CORNELL e KONOLD, 2012; KIRK et al. 2017; MITRA, 2009; THOMPSON, 2009; OLIVEIRA e SOARES, 2011; HERRERA e MORENO, 2017, entre outros).

As revisões de literatura apresentadas nos capítulos dois e três foram essenciais para a realização de outra etapa desta pesquisa: a construção de um questionário. A leitura e análise dos estudos produzidos nos últimos anos apoiaram a elaboração dos itens que estão presentes no instrumento "Jovens e escolas: quais as relações?" que será apresentado no capítulo 4. Além da apresentação do questionário, o quarto capítulo traz uma análise dos instrumentos de pesquisa já existentes que tratam da relação da juventude com a escola, a identificação dos conceitos primários e secundários que estão no instrumento desenvolvido bem como a sua operacionalização e a construção dos itens que medem cada um dos conceitos.

No capítulo 5 exibimos a validação teórica do questionário desenvolvido e discorremos acerca dos caminhos de pesquisa traçados em meio à pandemia da Covid-19 e que motivou um esforço importante de mudança de planos e estratégias para realizar a presente pesquisa com qualidade. A escolha dos jovens e das escolas e os desafios vividos na aplicação dos questionários, online e presencial, são expostos ao longo desse capítulo. Em um segundo momento, apresentamos todo o processo de validação empírica do questionário a partir da técnica de análise de fatores (CAZELLI, 2005; OLIVERA, 2015) que orientou a verificação da eficácia e da confiabilidade do instrumento desenvolvido.

O sexto capítulo apresenta as análises dos dados obtidos através da aplicação dos questionários para 224 jovens de escolas localizadas em São Luís (MA) e do Rio de Janeiro (RJ). O capítulo foi dividido em seções que apresentam o perfil dos jovens presentes na amostra, suas motivações para irem à escola, suas percepções sobre o clima escolar, sobre a participação discente e sobre a autoeficácia. Analisamos esses fatores por dependências administrativas das instituições pesquisadas (públicas e particulares) com o intuito de compreender como os jovens pertencentes a diferentes grupos sociais e estudantes de organizações escolares distintas se relacionam com a escola. Por fim, no último capítulo deste trabalho, trazemos algumas reflexões sobre os principais resultados obtidos na nossa pesquisa e as contribuições deste trabalho para a pesquisa no campo da educação. 


\section{2.}

\section{A juventude e os jovens brasileiros}

Em 1985, por ocasião do Ano Internacional da Juventude, a Assembleia Geral da Organização das Nações Unidas (ONU) definiu pela primeira vez a juventude, considerando jovens aqueles indivíduos que possuíam entre 15 a 24 anos de idade. A entrada na juventude, aos 15 anos, significava o amadurecimento das funções sexuais e reprodutivas, que interferiam nas dinâmicas físicas, biológicas e psicológicas dos indivíduos. A saída da juventude, aos 24 anos, significava a conclusão do ciclo de educação formal e a entrada no mercado de trabalho, seguido da constituição das próprias famílias (CAMARANO et. al., 2014). Atualmente, no Brasil, de acordo com o Estatuto da Juventude sancionado pela lei $\mathrm{n}^{\mathrm{o}} 12.852$ de 5 de agosto de 2013, considera-se jovem todo cidadão com idade entre 15 e 29 anos (BRASIL, 2013, Art. $1^{\circ}$ ).

As referências etárias são importantes para o reconhecimento das necessidades desse grupo e para a elaboração de políticas públicas para o segmento. No entanto, diversos estudiosos do tema defendem que a entrada e a saída da juventude não devem ser entendidas como fenômenos homogêneos, vividos de forma semelhante em todos os segmentos sociais. Ao contrário, o pertencimento a esse grupo está diretamente relacionado com as experiências e condições vividas pelos jovens, não sendo incomum a transição para a vida adulta seja feita precocemente, principalmente nas camadas mais desfavorecidas da sociedade (BARCELLOS, 1990; BOURDIEU, 1996; SPOSITO, 2005; DAYRELL, 2015).

Levando em conta essas diferentes formas de enxergar a juventude, o presente capítulo será divido em dois momentos. No primeiro momento analisamos o conceito de juventude a partir das diferentes correntes sociológicas com o intuito de apresentar as possibilidades de se pensar o conceito da juventude a partir de alguns autores desse campo. No segundo momento, apresentamos algumas características da juventude no Brasil, a partir dos dados da PNAD Contínua de 2019 e, posteriormente, discutimos a relação da juventude com a escola no Brasil, apresentando uma revisão bibliográfica dos estudos desenvolvidos nos últimos dez anos sobre os desafios referentes à escolarização dessa população. 


\section{1. Juventude ou Juventudes? As perspectivas sociológicas sobre o tema}

Tratar da juventude a partir de um recorte geracional ou social e econômico é uma discussão que feita há muitos anos por diferentes estudiosos. Quando descrevemos a juventude a partir do seu recorte geracional estamos evidenciando que um determinado grupo de pessoas era jovem quando certos acontecimentos vieram à tona, no entanto, isso não significa que os sujeitos pertencentes a esse grupo vivenciaram esses acontecimentos da mesma forma. Apesar do contexto político, social e econômico influenciar a forma como a juventude vive essa etapa da vida, diversos estudos vêm apontando que gênero, raça, cor, origem socioeconômica, local de moradia e diversos outros fatores influenciam fortemente o modo de ser jovem.

Luis Antonio Groppo (2017) em sua análise das concepções sobre juventude elaboradas pela Sociologia e, baseando-se nas ideias de Tomaz Tadeu da Silva (2010) para as teorias do currículo, agrupa os principais paradigmas e referenciais teóricos em três conjuntos: teorias tradicionais, teorias críticas e teorias pós-críticas.

As teorias tradicionais, de acordo com Groppo (2017), emergem na primeira metade do século passado nos Estados Unidos e estão preocupadas com a integração das novas gerações, ou dos grupos juvenis, na sociedade moderna. De acordo com essas teorias, a juventude “(...) é concebida como uma faixa etária ou categoria etária mais ou menos evidente, natural e universal, quase que determinada biopsicologicamente, cabendo apenas ao meio social reconhecer as propriedades intrínsecas deste momento do curso da vida" (GROPPO, 2017, p. 10). Além disso, é o momento em que se completa a socialização primaria vivenciada na infância com a família, e se inicia a socialização secundária, em que os indivíduos são conduzidos pelos valores e rotinas das instituições sociais que transcendem a vida privada e familiar. Para os defensores das teorias tradicionais, a juventude interessa menos pelo o que ela é e mais pelo que vai ser quando os membros se tornarem adultos. Segundo Groppo (2017), o marco teórico mais influente desta perspectiva foi o estrutural-funcionalismo de Talcott Parsons e o mais importante livro da tendência foi escrito por Shmuel Noah Eisenstadt, em 1976, intitulado "De geração a geração". 
Já as teorias críticas emergem na segunda metade do século XX e tratam da possibilidade das novas gerações contribuírem para a reforma ou transformação do sistema social (GROPPO, 2016). Duas tendências principais marcam as teorias críticas: a corrente geracional e a corrente classista. Em relação a primeira, de acordo com Pais (1990), a principal questão discutida no âmbito desta corrente está relacionada com a continuidade/descontinuidade dos valores intergeracionais. Segundo o autor, quando há uma socialização contínua, os jovens são socializados a partir dos valores e normas já existentes e predominantes nas gerações mais velhas. Em contrapartida, a descontinuidade da socialização ocorre quando há uma tensão, confrontação e ruptura com as normas e valores já estabelecidos. Nesse último caso, os jovens criam entre eles uma consciência geracional muito própria, rompendo com os padrões das gerações mais antigas.

Num como noutro caso, para a corrente geracional, a renovação e a continuidade da sociedade dependeriam da relação entre as gerações, dialeticamente submetias a uma outra forma de tensão. Para esta corrente, os indivíduos experimentariam o seu mundo, as suas circunstâncias e os seus problemas, como membros de uma geração, e não como membros de uma classe social (como é defendido pela corrente classista). Isto é, para a corrente geracional, as experiências de determinados indivíduos são compartilhadas por outros indivíduos da mesma geração, que vivem, por esse facto circunstâncias semelhantes e tem problemas similares (PAIS, 1990, p. 154).

Dessa forma, para essa vertente da Sociologia, a problemática da juventude está relacionada com a continuidade e descontinuidade intergeracionais, dilema vivido pela juventude como um todo, independentemente da classe social. Karl Mannheim é o principal representante dessa perspectiva. De acordo com o autor, a juventude compartilha a função de agente revitalizador - por ainda não estar totalmente comprometido com o status quo e nem ter seus interesses entrelaçados com a ordem social, tem a possibilidade de se organizar para promover mudanças na sociedade. A juventude é o momento em que o sujeito começa a sair do seio familiar e a estabelecer vínculos mais autônomos com a sociedade, passando a questionar a ordem já existente que, na maioria das vezes, se confronta com os seus movimentos dinâmicos.

Em contrapartida, a segunda vertente, denominada corrente classista, concentra-se em compreender a juventude a partir da sua diversidade. Para os 
autores dessa corrente, a diversidade se sustenta, principalmente, nas questões de classe social.

A juventude como um conjunto social necessariamente diversificado, em razão das diferentes origens de classe, que apontam para uma diversidade das formas de reprodução social e cultural. As culturas juvenis seriam sempre culturas de classe. Como produto das relações sociais antagônicas, expressariam sempre um significado político de resistência, ganhando e criando espaços culturais. (PAIS, 1993 p. 21-22).

Sendo assim, para essa vertente, a diferença entre as juventudes está relacionada, principalmente, com o pertencimento a determinada classe social, que determinaria o tipo de juventude vivenciada por esses sujeitos. Um jovem de origem popular experimenta essa fase da vida de forma diferente dos jovens de classes mais privilegiadas, que têm acesso a outros meios culturais e sociais. Por esse motivo, não seria possível compreender o termo juventude de forma homogênea, associada apenas a uma fase da vida.

Bourdieu (1983) em entrevista intitulada "Juventude é apenas uma palavra" discute sobre as disputas em relação ao que é ser jovem em cada sociedade e aponta que a experiência juvenil não se apresenta para todos da mesma forma, pois o sentido de ser jovem varia de acordo com a classe social, econômica, gênero e raça. Sendo assim, construir uma definição homogênea de juventude limita as possibilidades de análise e desconsidera a realidade da sociedade.

Barcellos (1990) dialoga com as reflexões apresentadas por Bourdieu e utiliza o conceito de "Juventudes", no plural, para enfatizar as diversas formas de experimentar o "ser jovem", considerando todos os cenários socioculturais. Para o autor, a noção de juventude varia não apenas de sociedade para sociedade, mas dentro da mesma sociedade, ao longo do tempo e de acordo com suas estratificações internas. De acordo com Abramo (2005), falar em "juventudes", no plural, revela uma mudança importante no termo que permite entender os diferentes modos como essa condição pode ser vivida. Sendo assim, "a juventude, mesmo que não explicitamente, é reconhecida como uma condição válida, que faz sentido para todos os grupos sociais, embora apoiada sobre situações e significações diferentes" (ABRAMO, 2005, p. 44).

Por fim, as teorias pós-críticas que surgem no final do século XX têm em comum o fato de considerarem que a sociedade moderna foi superada, totalmente 
ou em parte, e que a juventude, como foi tradicionalmente concebida pela Sociologia, também sofreu rupturas. Segundo Groppo (2017) essa teoria se apresenta em duas correntes: pós-moderna/pós-estruturalista e segunda modernidade.

A primeira corrente das teorias pós-críticas, denominada de pós-moderna ou pós-estruturalista, defende que já vivemos em um mundo pós-moderno. De acordo com Groppo (2017), nesta perspectiva se destaca a noção de "juvenilização" derivada da obra de Jean Baudrillard, que seria uma transformação da juventude em valor-signo, que pode ser comprado por quem deseja ostentar a valiosa juventude e tem recursos para tanto. Outra noção presente nessa corrente é a de tribos juvenis, defendida por Michel Maffesolli. Para ele, a pós-modernidade é marcada pela multiplicação dos tipos de sociabilidades, a formação de tribos efêmeras (com relações emotivas e intensas) e o enfraquecimento das relações sociais institucionalizadas em troca da inserção em tribos identitárias.

A segunda corrente das teorias pós-críticas, denominada segunda modernidade, ganhou mais espaço nos últimos trinta anos, tendo sido inclusive usada como referência para a elaboração de várias políticas públicas no Brasil. De acordo com Groppo (2017, p. 11), esta seria responsável por "relativizar a concepção de socialização e de categorias etárias oriundas da primeira modernidade, propondo que as juventudes contemporâneas efetuam múltiplas e ativas socializações”. Para os principais defensores dessa teoria - Anthony Giddens, Ulrich Beck, Zygmunt Bauman, José Machado Pais e Helena Wendel Abramo - os marcadores tradicionais da entrada na idade adulta implodiram, o processo de transição para a vida adulta não é mais linear e as socializações são múltiplas e ativas. Dessa forma, sair da casa dos pais, casar-se, ter filhos, entrar no mercado de trabalho, são eventos que podem acontecer em sequências variadas e com arranjos múltiplos, sem uma ordem necessária.

Além disso, para os defensores da teoria há um rompimento com a noção tradicional de socialização como via de mão única, conforme apontado por Durkheim (1978), em que as gerações adultas educariam as mais novas. Nesse mundo contemporâneo, as transformações econômicas, tecnológicas, políticas e culturais são tão rápidas que impedem a cristalização de distintas identidades geracionais. Dessa forma, jovens e adultos experimentam os mesmos desafios e aprendem uns com os outros, rompendo com o modelo de socialização no qual as 
gerações mais velhas transmitiam suas experiências às mais novas (GROPPO, 2017).

Abad (2003) - em pesquisa sobre políticas públicas para a juventude na Colômbia - sugere a distinção entre condição e situação. A condição jovem estaria relacionada a uma dimensão histórica geracional, expressando o modo como a sociedade compreende e atribui significado a essa etapa de vida, relacionada ao modo como ela é vivenciada pelos jovens, levando em consideração as suas diferenças sociais de classe, gênero, cor etc. Nesse sentido, quando falamos da juventude do século XV ou dos anos 2000, por exemplo, estamos falando de uma condição (esses indivíduos são jovens no momento marcado por transformações históricas, políticas e sociais), no entanto, a forma como cada indivíduo vai vivenciar essa condição dependerá das suas especificidades econômicas, sociais, de gênero e etnia, ou seja, da sua situação.

Esta breve revisão sobre as diferentes correntes da Sociologia da Juventude sugere que elas podem ser consideradas, em certa medida, como perspectivas complementares para pensar sobre a juventude em seus múltiplos aspectos. Nessa pesquisa, especificamente, privilegiamos um recorte geracional e classista, por entendermos que existem aspectos comuns a diferentes juventudes que são compartilhados por todos que se inserem dentro de determinada faixa-etária, mas que as especificidades desse grupo estão presentes quando consideramos suas características do ponto de vista racial, socioeconômico e de gênero. Como apontado por Bernard Charlot (2006, p. 2):

É inegável que se encontram vários tipos de jovens, bastante diferentes entre eles. Todavia é difícil descartar a ideia de que há elementos comuns entre eles, por mais diferentes que sejam. Além da "cultura jovem", ou melhor, dos traços comuns às várias "culturas jovens", sempre há pelo menos características comuns a todos, inclusive na abordagem de Bourdieu: esses jovens são considerados jovens pelos adultos e por si mesmos. Portanto, quando se pensa em juventude e jovens, não se pode renunciar nem ao plural, nem ao singular. Os jovens são diferentes, mas têm em comum o fato de serem considerados jovens e terem que lidar com os adultos. Essa relação entre gerações é fundamental para entender como são os jovens e o que é juventude em um determinado lugar e momento da história.

Além das especificidades relacionadas ao momento em que a juventude é vivida e a situação socioeconômica em que está inserida, é importante frisar que o 
modo de ser e viver dos jovens também se altera a partir do contexto local em que está inserida. A juventude do século XIX na Europa não era a mesma do Brasil na mesma época, os acontecimentos e movimentos que eclodiam em determinado momento lá, não aconteceram simultaneamente aqui, sendo assim, as demandas e sentimentos da juventude estão muito relacionadas as trajetórias especificas de cada país. Portanto, além de "quando" é preciso perguntar "onde" estava a juventude de cada tempo. É fato que com o advento das novas tecnologias e meios de comunicação, isso mudou e torna-se cada vez mais fácil identificar homogeneidades nas identidades juvenis, mas ainda são grandes as diferenças entre os jovens de diferentes lugares do mundo. Na próxima seção traçamos um desenho da situação da juventude no Brasil utilizando dados estatísticos divulgados pelo Instituto Brasileiro de Geografia e Estatísticas (IBGE) e pesquisas brasileiras sobre o tema, com o intuito de compreender as especificidades de ser jovem no Brasil no século XXI.

\section{2.}

\section{As juventudes brasileiras}

Até os anos 1960, a visibilidade da juventude brasileira ficou restrita aos jovens escolarizados de classe média e aos seus papeis na continuidade ou transformação do cenário social e político herdados das gerações anteriores (ABRAMO, 2005). Apesar do cenário de desigualdades que o Brasil vive desde os seus primórdios, a preocupação com os grupos de jovens em situação de vulnerabilidade e risco tem crescido apenas nos últimos trinta anos (PEREIRA e LOPES, 2016). De acordo com Abramo (2005), a visibilidade desse grupo emerge por duas questões:

Em certa medida, como ampliação da preocupação vigente com a adolescência, na "descoberta" de que os problemas de vulnerabilidade e risco não terminam aos 18 anos, mas muitas vezes se intensificam a partir daí. Mas também pelo aparecimento de novos atores juvenis, em grande parte dos setores populares, que vieram a público, principalmente por meio de expressões ligadas a um estilo cultural, colocar questões que os afetam e preocupam, diferentes daquelas colocadas pelas gerações juvenis precedentes, e para as quais não havia nem mesmo formulações elaboradas no plano da política. (p.39) 
Sendo assim, os grupos juvenis de origem popular que até outrora eram excluídos dos debates acerca da juventude, desde os anos 1990, têm ocupado um lugar central não apenas nos debates acadêmicos do campo mas também nas agendas dos governantes do país. Algumas das principais ações que caracterizaram essa virada em relação a visibilidade da juventude menos favorecida foram a criação da Lei $\mathrm{n}^{\circ}$ 11.129, de 30 de junho de 2005 que originou a Secretaria Nacional da Juventude (SNJ), a fundação do Conselho Nacional da Juventude (Conjuve) e a elaboração do "Programa Nacional de Inclusão de Jovens", mais conhecido como "Projovem". Outra medida que merece destaque é a promulgação do Estatuto da Juventude, na Lei ${ }^{\circ} 12.852$, em 05 de agosto de 2013, que dispõe sobre os direitos dos jovens, os princípios e diretrizes das políticas públicas de juventude e o Sistema Nacional de Juventude - SINAJUVE.

Outro ponto a ser considerado em relação à visibilidade dos jovens é o crescimento de estudos sobre o perfil da juventude brasileira, que têm se mostrado de extrema importância para o entendimento da realidade do país e, posteriormente, para elaboração de políticas para esse grupo da população. Nos últimos anos podemos enumerar diversos estudos desenvolvidos em escala nacional acerca das características e vivências da juventude no Brasil, tais como: Perfil da Juventude Brasileira (2003), desenvolvida pelo Instituto Cidadania; Juventudes Brasileiras, realizada em 2004 pela UNESCO; Juventudes sul-americanas: diálogos para a construção da democracia regional, feito em 2008 pelo Ibase e pelo Instituto Pólis e a pesquisa Agenda Juventude Brasil (2013) elaborada pelo Observatório Participativo da Juventude. Como apontado por Novaes e Venturi (2016), estudos como esses são relevantes não apenas para traçar um perfil da juventude brasileira, mas, principalmente, para "acompanhar as tendências de comportamento e opinião dos jovens, identificar as demandas por políticas públicas e aferir a ressonância de algumas respostas em curso" (p.9).

De acordo com Sposito, Souza e Silva (2017), a compreensão do perfil da juventude brasileira através de pesquisas quantitativas ainda se mostra importante pois possibilita a problematização e a abertura de um leque de questões que demandam novas investigações.

Consideramos que os dados quantitativos apresentam um conjunto de temas capazes de estimular a reflexão, de modo a nutrir a pesquisa qualitativa com novos problemas e, sobretudo, ampliar a produção de conhecimentos sobre os jovens no Brasil" (SPOSITO, SOUZA e SILVA, 2017, p. 3). 
Acreditamos que compreender o perfil e as demandas da juventude brasileira, utilizando dados mais recentes será muito importante para o presente estudo, podendo contribuir para novas reflexões acerca da relação das juventudes com os espaços escolares, os seus hábitos e experiências, assim como para a formulação dos itens do questionário que fará parte desta pesquisa.

\subsection{1.}

\section{A situação dos jovens brasileiros}

A Pesquisa Nacional por Amostra Domiciliar Contínua (PNAD Contínua) ${ }^{3}$ de 2019 (edição mais recente disponível) descreve a situação da juventude brasileira nos seguintes aspectos: educação e trabalho, acesso a tecnologias e outras formas de trabalho. O Instituto Brasileiro de Geografia e Estatísticas (IBGE) define como jovem a população entre 15 e 29 anos de idade. Para o presente estudo, no entanto, entendemos que esta é uma faixa bem ampla e que, por mais que todos sejam considerados jovens, existem algumas especificidades relacionadas a cada fase da juventude. Dessa forma, como o foco deste estudo é a juventude em processo de escolarização, priorizaremos, quando possível, um recorte de até 24 anos, entendendo que apesar dessa faixa-etária não ser idealmente a que está presente na escola, ainda existe um percentual significativo dessa juventude em instituições de ensino, como os dados a seguir apontam.

\subsubsection{1}

\section{Educação e trabalho}

A inserção da juventude na escola é um fenômeno novo no Brasil e apesar dos avanços ocorridos nas últimas três décadas, por muito tempo a escola não fez a juventude e o trabalho era central na vida desse grupo (DAYRELL, 2007). O aumento tardio, mas expressivo, da juventude brasileira nas instituições escolares foi oportunizado pela expansão do sistema educacional do país na década de 1990, que resultou em um aumento significativo do número de alunos matriculados em todos os segmentos da educação básica.

\footnotetext{
${ }^{3}$ A PNAD Contínua é uma pesquisa nacional que busca acompanhar as alterações trimestrais e a evolução, no curto, médio e longo prazos, da força de trabalho e outras informações necessárias para o estudo do desenvolvimento socioeconômico do país (habitação, característica gerais dos moradores, acesso à televisão e à internet, educação, entre outros aspectos). Fonte: https://www.ibge.gov.br/estatisticas/sociais/trabalho/17270-pnad-continua.html?=\&t=o-que-e
} 
De acordo com Oliveira e Araújo (2005), apesar da multiplicidade de significados do que seria qualidade na educação, no Brasil, três indicadores perpassam os discursos quando se fala em um sistema de ensino de qualidade: acesso, fluxo e desempenho. A partir do final da década de 1990, em que pese o acesso praticamente universalizado ao ensino fundamental, os desafios para a garantia de uma educação de qualidade no país continuaram sendo a melhoria do fluxo e do desempenho dos alunos. De acordo com os autores, a ampliação das oportunidades de escolarização não foi acompanhada por uma preocupação com a qualidade do ensino que seria oferecido nas escolas e o acesso de um público até então excluído da escola à educação básica foi seguido por altas taxas de evasão, repetência e ampliação da distorção idade-série, logo visibilizado como baixo desempenho nas avaliações de larga escala implementadas nacionalmente através do $\mathrm{SAEB}^{4}$ a partir de 1995. Sendo assim, “os obstáculos à democratização do ensino foram transferindo-se do acesso para a permanência com sucesso no interior do sistema escolar" (OLIVEIRA e ARAÚJO, 2005, p. 10).

Os dados da PNAD Contínua de 2019 sobre a educação revelam como os desafios de atraso e evasão dos alunos ainda são latentes no Brasil. A pesquisa utiliza dois indicadores principais para retratar a situação da educação no país: a taxa de escolarização, que revela a proporção de estudantes de determinada faixaetária em relação ao total de pessoas dessa mesma faixa-etária no país, e a taxa ajustada de frequência escolar líquida, que retrata a proporção de estudantes com idade prevista para estar cursando a uma determinada etapa de ensino e a população total dessa mesma faixa-etária (IBGE, 2020).

Em relação a primeira, os dados apontam uma taxa de escolarização da juventude de 15 a 17 anos de 89,2\%, apenas um ponto percentual acima de 2018 . Apesar do modesto aumento, a taxa ainda é inferior à meta de universalização prevista pela Lei de Diretrizes e Bases de 1996 (Lei n. 9.394, de 20.12.1996) e pelo Plano Nacional de Educação (PNE) de 2014 que definiu a universalização do ensino para estudantes de 15 a 17 anos até 2016. Já entre a juventude que compreende a faixa-etária de 18 a 24 anos, que idealmente já estaria fora da educação básica, o

\footnotetext{
${ }^{4}$ O Sistema de Avaliação da Educação Básica (Saeb) é um conjunto de avaliações externas em larga escala que permite realizar um diagnóstico da educação básica brasileira e de fatores que podem interferir no desempenho do estudante. Fonte: https://www.gov.br/inep/pt-br/areas-deatuacao/avaliacao-e-exames-educacionais/saeb. Acesso em: 19 de janeiro de 2021.
} 
levantamento aponta que $11 \%$ ainda estavam frequentando esse espaço no ano de 2019 (IBGE, 2020).

No que se refere a taxa de frequência escolar líquida, os resultados são mais preocupantes. De acordo com os dados da PNAD Contínua 2019, enquanto as séries iniciais do ensino fundamental atingiram a taxa de 95,8\% de alunos na série adequada, nos anos finais desse mesmo segmento, que concentra alunos de 11 a 14 anos, o percentual foi de $87,5 \%$, havendo uma melhora de apenas 0,8 pontos percentuais em relação a 2018 (IBGE, 2020). Isto significa que 12,5\% dos indivíduos de 11 a 14 anos não estão frequentando as séries finais do Ensino Fundamental, como seria o previsto.

Outro fato importante é que a análise das taxas de frequência escolar líquida para os anos finais do Ensino Fundamental considerando as diferentes regiões do país e o sexo e a cor dos estudantes, evidencia as desigualdades presentes no país. Os dados apontam que o Centro-Sul do país registrou taxas de frequência escolar líquida acima de $89 \%$ enquanto as regiões Nordeste e Norte ficaram abaixo da média nacional, respectivamente, $83,4 \%$ e $81,2 \%$. Em relação ao sexo, entre os homens de 11 a 14 anos, 85,8\% estavam, pelo menos, frequentando o ensino fundamental e entre as mulheres, essa proporção foi de 89,3\%. Por fim, no que tange o fator cor, entre os jovens de cor branca, 90,4\% estavam na idade série adequada e entre os jovens de cor preta ou parda essa taxa foi de 85,8 (IBGE, 2020).

Além da cor e raça, os dados da Pnad Contínua 2020 apontam que a situação econômica vivida pelo jovem também possui impacto na sua trajetória escolar. Como mostram os dados do relatório divulgado no ano de 2020, a maior distância percentual dos jovens que concluíram o Ensino Fundamental até os 16 anos é entre os $25 \%$ mais pobres e os $25 \%$ mais ricos (26 pontos).

Como os dados apontam, o atraso escolar se acentua nos anos finais do ensino fundamental quando $12,5 \%$ dos estudantes de 11 a 14 anos já possuíam uma defasagem idade-série de dois anos ou mais, número que aumenta quando consideramos a determinadas características socioeconômicas dos alunos. Esse atraso na conclusão do ensino fundamental se reflete negativamente nas taxas de frequência escolar líquida do ensino médio, que deveria abranger todos os alunos de 15 a 17 anos.

Apesar da meta definida pelo Plano Nacional de Educação (PNE, 2014) prever o alcance de $100 \%$ do atendimento escolar para adolescentes entre 15 e 17 
anos até 2016 e elevar, até 2024, a taxa líquida de matrículas dessa faixa etária no ensino médio para $85 \%$, o relatório do $3^{\circ}$ Ciclo de Monitoramento das Metas do PNE (INEP, 2020) indica que nenhuma das metas foram alcançadas. De acordo com o documento, ainda havia 680 mil jovens de 15 a 17 anos fora da escola em 2019 - déficit que deveria ter sido sanado três anos antes. Além disso, a taxa líquida de matrículas dessa faixa etária no ensino médio ficou em 73,1\% em 2019, longe da meta estipulada (INEP, 2019).

Entre as regiões, a diferença das taxas líquida de matrícula vem persistindo ao longo dos últimos anos (2012-2019), como mostra o gráfico abaixo.

\section{Gráfico 1 - Percentual da população de 15 a 17 anos de idade que frequentava 0 Ensino Médio ou havia concluído a educação básica, por Brasil e grande região - 2012 - 2019}

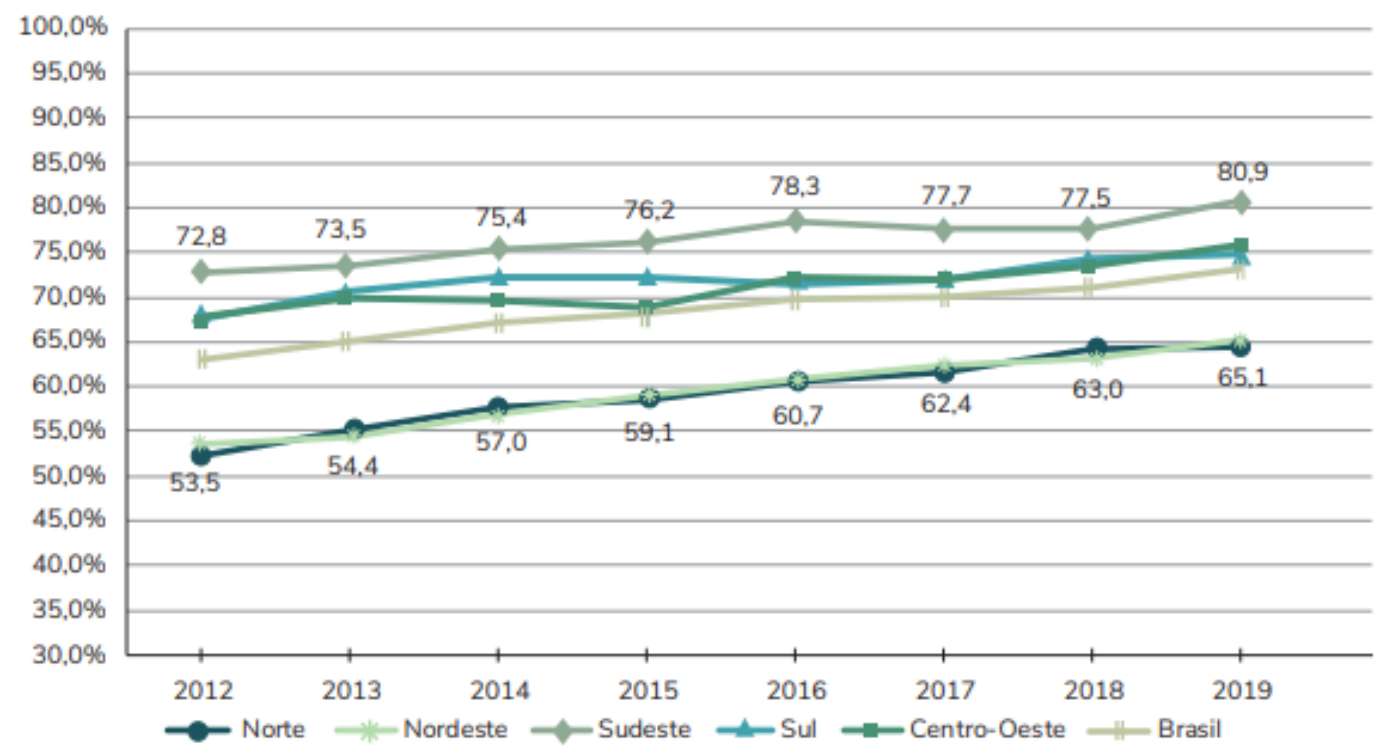

Fonte: Elaborado pela Dired/Inep com base nos dados da Pnad Contínua (2012-2019)

As regiões Norte e Nordeste apresentaram as menores taxas de frequência escolar líquida: $64,6 \%$ e 65, 1\%, respectivamente. Em contrapartida, o Sudeste é a região que vem mantendo, desde 2012, as melhores taxas. Além das regiões, também há diferenças de gênero e de cor nos percentuais de jovens de 15 a 17 anos que estão no Ensino Médio ou já finalizam o Ensino Fundamental. Os gráficos abaixo apontam que o acesso ao Ensino Médio é mais recorrente para as meninas e para os jovens brancos. 
Gráfico 2 - Percentual da população de 15 a 17 anos de idade que frequentava o Ensino Médio ou havia concluído a educação básica, por sexo - Brasil - 2012 -2019.

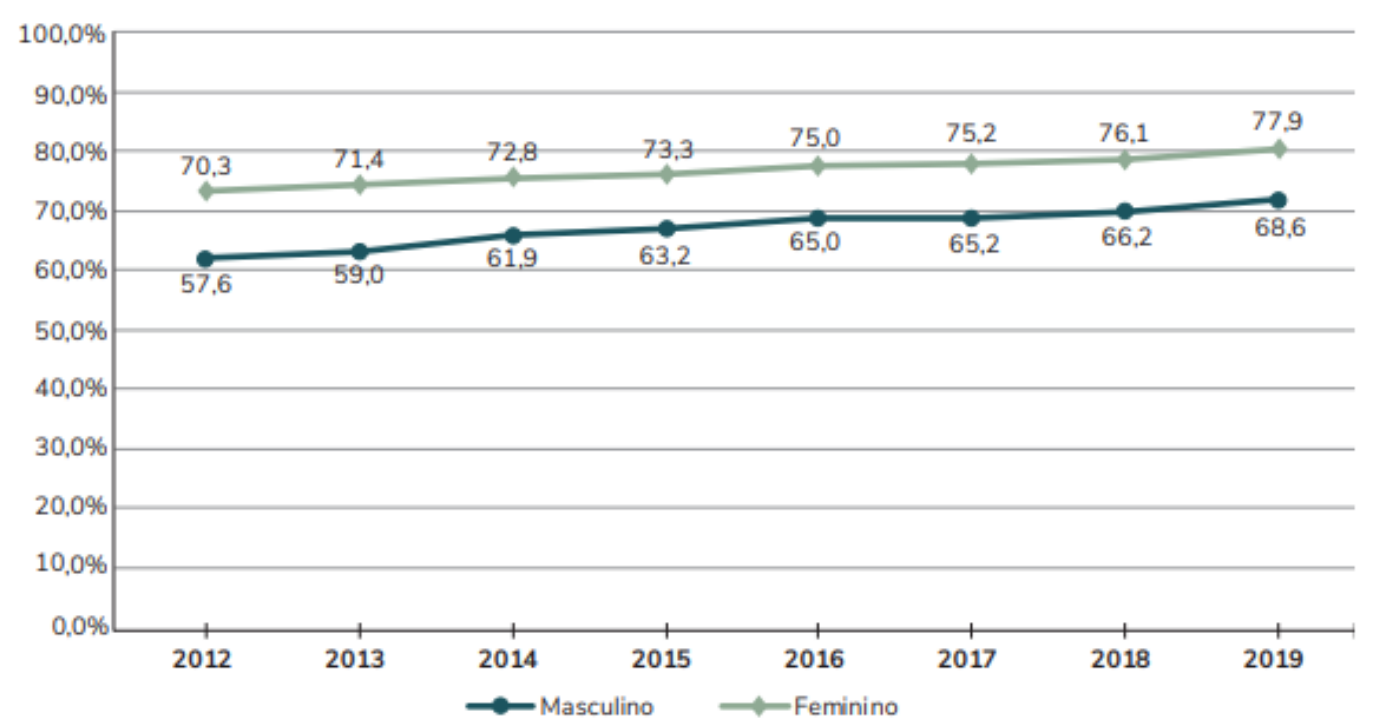

Fonte: Elaborado pela Dired/Inep com base nos dados da Pnad Contínua (2012-2019).

Gráfico 3 - Percentual da população de 15 a 17 anos de idade que frequentava 0 Ensino Médio ou havia concluído a educação básica, por cor/raça - Brasil - 2012 2019.

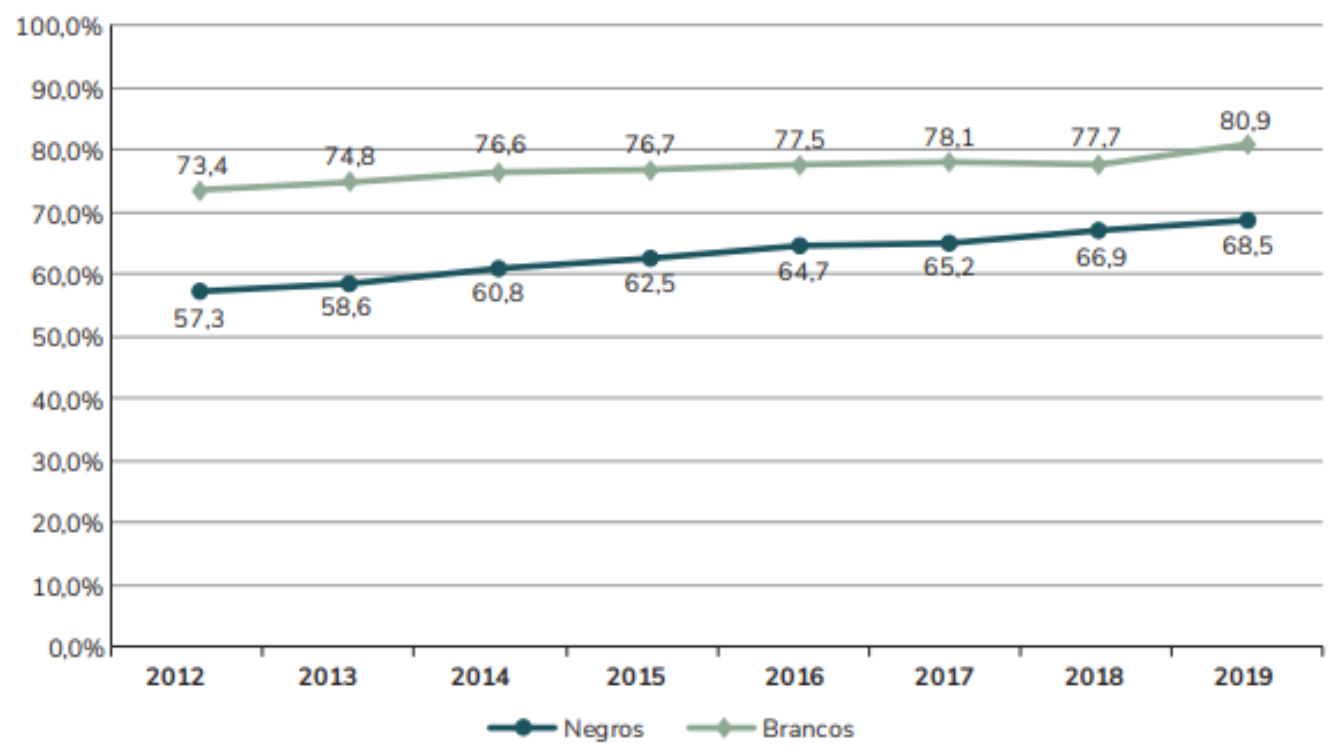

Fonte: Elaborado pela Dired/Inep com base nos dados da Pnad Contínua (2012-2019).

Diante desses dados, podemos concluir que um dos os maiores desafios da escola brasileira seria buscar a universalização da escolarização básica com qualidade e equidade, ou seja, garantido que todos permaneçam e concluam os seus estudos com domínio dos conhecimentos historicamente produzidos e com 
formação para a participação na vida social e produtiva, independentemente de origem socioeconômica, cor ou sexo.

Em relação à tríade juventude, educação e trabalho, outro levantamento importante feito pela Pesquisa Nacional de Amostra Domiciliar Contínua (IBGE, 2019) revela que, em $2019,39,1 \%$ dos jovens indicaram que o principal motivo de terem abandonado o estudo ou nunca terem frequentado a escola era a necessidade de trabalhar. Entre os homens, esse percentual foi de $50 \%$ e entre as mulheres foi de 28,8\% (IBGE, 2020).

Como os dados e as pesquisas no campo da juventude indicam, educação e trabalho são caminhos que se entrecruzam na trajetória dos jovens, principalmente em determinadas categorias sociais e econômicas. Educação e trabalho são peçaschave para compreender a realidade da juventude no Brasil. Apesar da crescente centralidade da escola, principalmente para os jovens de 15 a 17 anos, como destacado por Dayrell (2007), a condição juvenil muitas vezes só é vivenciada através do trabalho, que garante o mínimo de recursos para o lazer, namoro e consumo, dimensões que também perpassam a experiência juvenil.

Além das formas de trabalho para ocupação, a Pesquisa Nacional de Amostra por Domicílios Contínua (PNAD Contínua) também analisa outras formas de trabalho que foram definidas pela $19^{\mathrm{a}}$ Conferência Internacional do Trabalho em 2013, são elas: afazeres de casa, o cuidado de pessoas, o trabalho voluntário e a produção para o próprio consumo (IBGE, 2019). No âmbito deste estudo, decidimos analisar a frequência dos jovens nos "afazeres de casa" e no "cuidado de pessoas" tendo em vista os estudos que discutem a influência dessas atividades na escolarização dos jovens (VENDRAMINI et al., 2017; BRUSCHINI, 2006). Nessa direção, a PNAD Contínua para Educação de 2019 apontou que, entre as mulheres, a necessidade de realizar afazeres domésticos e cuidados de pessoas foi alegada por 38,7\% delas como principal motivação para não seguir estudando ou ampliando a sua qualificação. Esse dado também demonstra como essas categorias de trabalho estão diretamente relacionadas as questões de gênero. Um retrato disso é que, entre os homens, apenas $0,9 \%$ não seguiram estudando ou ampliando a sua qualificação devido a necessidade de realizar afazeres domésticos ou cuidar de pessoas. 


\subsubsection{2 \\ Acesso à internet e a televisão e Posse de telefone celular para uso pessoal}

Além da situação de estudo e trabalho dos jovens, há pelo menos três décadas, o acesso às tecnologias e aos demais meios de comunicação digitais tornaram-se um dos preditores para a compreender a realidade de cada país. No Brasil, apesar da maioria da população ter acesso à internet e à televisão, a exclusão digital ainda se faz presente, principalmente quando analisamos determinados fatores sociais como cor, classe econômica e lugar de moradia. Se há muito esse tema já possuía uma relevância central, no contexto atual, tornou-se ainda mais necessário debater sobre o assunto. A pandemia da Covid-19 iniciada em 2020 trouxe imensos desafios que desnudaram ainda mais as desigualdades presentes no país, algumas delas relacionadas à educação e ao acesso às TIC (Tecnologias da Informação e Comunicação).

A Pesquisa Nacional de Amostra por Domicílios Contínua (PNAD Contínua) de 2018 (a mais recente que analisa essa categoria), investigando o acesso à internet e à televisão e a posse de telefone celular no Brasil, confirma esse quadro. Em relação à existência de televisão no domicílio, em 2018, 96,4\% dos domicílios possuía esse tipo de ferramenta digital. No que se refere a existência de microcomputador ou tablet no domicílio, os dados demonstram que, em 2018, 41,7\% dos domicílios possuíam computador e 12,5\% possuíam tablets (IBGE, 2018). A diferença do rendimento médio per capita domiciliar em relação à existência desses equipamentos no domicílio foi o mais marcante: nas residências em que não havia nem computador e nem tablet o rendimento foi de $\mathrm{R} \$ 957 \mathrm{e}$ naquelas em que havia pelo um deles o valor subiu para $\mathrm{R} \$ 2.404$ (IBGE, 2018).

Sobre a utilização da Internet no domicílio, em 2018, 79,1\% dos brasileiros utilizavam a rede no país. Entre aqueles que não utilizavam, 24,3\% alegaram que o não uso se dava pelo alto preço da internet (IBGE, 2019). Por fim, no que se refere à posse de telefone celular para uso pessoal entre a população de 10 anos ou mais, os dados da PNAD Contínua de 2018 apontam que 79,3\% das pessoas possuem essa ferramenta. Em relação as regiões do país, a Região Norte e Nordeste possuíram os menores percentuais, sendo $67,4 \%$ e $70,7 \%$, respectivamente.

Os dados apresentados nesta subseção mostram as desigualdades presentes no acesso as tecnologias no Brasil, sendo as regiões Norte e Nordeste e as famílias 
de nível socioeconômico mais baixo as mais prejudicadas (IBGE, 2020). Nas demais categorias analisadas (educação, trabalho e outras formas de trabalho) essas desigualdades sociais e econômicas também estão presentes e retratam a os desafios enfrentados pela juventude no Brasil. No próximo capítulo, será feita uma discussão mais aprofundada acerca da relação da juventude com a escola, tendo em vista os trabalhos publicados nos últimos 10 anos sobre o tema, nas principais revistas e plataformas de pesquisa do país.

\section{3. \\ Os desafios à escolarização}

Além dos dados da PNAD Contínua de 2019 sobre a juventude brasileira, os resultados da Prova Brasil ${ }^{5}$ revelam que a questão da aprendizagem é mais um desafio a ser enfrentado pelo sistema educacional brasileiro. Em relação ao Ensino Médio, os dados apontam que apenas $1,62 \%$ dos estudantes da última série do Ensino Médio alcançaram níveis de aprendizagem classificados como adequados na avaliação de Língua Portuguesa (BRASIL, 2019a). Já nos anos finais do Ensino Fundamental, $81,4 \%$ dos alunos do $9^{\circ}$ ano alcançaram o nível básico ou insuficiente $^{6}$ na avaliação de Matemática e em Língua Portuguesa, os resultados foram um pouco melhores, mas ainda preocupantes: apenas 39,6\% dos alunos alcançaram um nível adequado de aprendizagem (BRASIL, 2019a). As razões para esses resultados são complexas e múltiplas, podendo ser explicadas por fatores de ordens distintas, sendo extra ou intraescolares.

Como defendido por Bernard Charlot (1996), ainda que não seja possível desconsiderar as razões socioeconômicas dessa realidade, não faria sentido pensar que a escola não tem qualquer influência nesse contexto. Diversos estudos sobre a relação da juventude com a escola vêm apontando que os jovens conferem diferentes significados ao fato de ir à escola e ao aprender. Charlot (1996) ao tentar compreender o motivo dessa diferença, utiliza os termos "mobilização em relação à escola" e "mobilização na escola" para discorrer sobre os processos que estruturam os distintos significados dados ao processo de escolarização. Segundo o

\footnotetext{
5 Avaliação censitária, em larga escala, aplicada no último ano de cada segmento do Ensino Fundamental ( $5^{\circ}$ e $9^{\circ}$ ano) e, desde 2017, também no último ano do Ensino Médio $\left(3^{\circ}\right.$ ano), com o objetivo de avaliar a qualidade do ensino oferecido pelo sistema educacional brasileiro. (fonte: http://portal.mec.gov.br/prova-brasil).

${ }^{6}$ Classificação qualitativa definida em (SOARES, 2009).
} 
autor, enquanto a "mobilização na escola" seria o investimento no ato de estudar, a "mobilização em relação à escola" se refere ao investimento no fato de ir à escola e aprender coisas. Neste estudo buscamos seguir esta perspectiva na elaboração do instrumento de pesquisa.

Durante a revisão das pesquisas brasileiras produzidas sobre o tema nos últimos 10 anos buscamos artigos científicos nas plataformas Google Acadêmico, Portal de Periódicos da CAPES, Scielo e nos portais dos Observatórios da Juventude da Universidade Federal Fluminense e da Universidade Federal de Minas Gerais. As palavras-chave utilizadas para a busca foram: juventude + escola; juventude + saber escolar; juventude + escolarização. Os achados dessa revisão, apresentados a seguir, apoiaram a elaboração dos itens do questionário desenvolvido neste estudo para aferir as mobilizações dos alunos em relação à escola e a importância que dão para o que aprendem nesse espaço.

Em nossa busca, encontramos onze artigos que discutiam as percepções e expectativas dos jovens sobre a escola, sendo que oito utilizam abordagens qualitativas (DAYRELL, REIS e LEÃO, 2011; BRENNER e CARRANO, 2014; RAMOS e SALVA, 2014; DAYRELL e MARTINS, 2015; STOSKI e GELBCKE, 2016; SANTOS, NASCIMENTO e MENEZES, 2012; ANDRADE, 2017; REIS, 2014) e três abordagens quantitativas em suas análises (TOMAZETTI et al., 2011; PEREIRA e LOPES; 2016; FREITAS, BATISTA e MELLO, 2017). Além disso, com exceção de um dos estudos (ANDRADE, 2017) todos os outros foram realizados com estudantes do Ensino Médio, o que demonstra uma escassez de pesquisas que contemplem os anseios de jovens estudantes de outras etapas de ensino.

No que se refere aos estudos que buscam aferir o que mobiliza os jovens a irem para escolar e estudar, foi possível perceber que todos eles indicam que os jovens, em sua maioria, vão para a escola pois desejam ingressar no ensino superior e conseguir uma boa posição no mercado de trabalho (TOMAZETTI et al., 2011; DAYRELL, REIS e LEÃO, 2011; PEREIRA e LOPES, 2016; FREITAS, BATISTA e MELLO, 2017; ANDRADE, 2017). Dessa forma, na visão dos jovens participantes das pesquisas, a escola seria um espaço privilegiado para a realização dos sonhos da juventude. Alguns autores, como Pereira e Lopes (2016), discutem que a razão para o deslocamento do sentido da escola para o futuro pode estar relacionada ao fato dos conteúdos da escola estarem distantes do interesse e do 
cotidiano dos jovens, como relataram os estudantes entrevistados em sua pesquisa. De acordo com os autores, os jovens afirmaram que o foco demasiado nos conteúdos do vestibular tornava o dia a dia maçante e tirava o prazer da descoberta e da aprendizagem.

Assim como a pesquisa de Pereira e Lopes (2016), outros estudos também buscam compreender o que afasta a juventude do seu processo de escolarização e o que faz com que os jovens permaneçam no ambiente escolar. Dentre os aspectos intraescolares mais destacados pelas pesquisas como motivos para que os jovens abandonem o espaço escolar estão a falta de diálogo dos saberes escolares com o cotidiano e interesse dos jovens (SANTOS, NASCIMENTO e MENEZES, 2012; BRENNER e CARRANO, 2014; DAYRELL e JESUS, 2015; ANDRADE, 2017), as metodologias mais tradicionais e não dialógicas utilizadas pelos professores (RAMOS e SALVA, 2014; DAYRELL e JESUS, 2015; STOSKI e GELBCKE, 2016), a falta de comunicação dos alunos com os professores (RAMOS e SALVA, 2014; DAYRELL, REIS e LEÃO, 2011; STOSKI e GELBCKE, 2016) e o fato das aulas serem chatas e cansativas (DAYREL e JESUS, 2015; ANDRADE, 2017).

Por outro lado, os principais aspectos mencionados pelos jovens como sendo responsáveis por eles gostarem e permanecerem no espaço escolar foram a existência de relações interpessoais de qualidade (RAMOS e SALVA, 2014; DAYRELL e JESUS, 2015; STOSKI e GELBCKE, 2016; SANTOS, NASCIMENTO e MENEZES, 2016) e a utilização de metodologias ativas e dialógicas durante as aulas (SANTOS, NASCIMENTO e MENEZES, 2012; RAMOS e SALVA, 2014; STOSKI e GELBCKE, 2016).

Mais uma vez, é importante frisar que não desconsideramos o fato de que a condição social e econômica vivenciada pelos jovens brasileiros sejam as principais causas dos desafios enfrentados pelos jovens ao longo das suas trajetórias de escolarização, no entanto, acreditamos que existem fatores dentro do ambiente escolar que influenciam essas trajetórias. A tese de doutoramento de Roseli Reis (2014) é um exemplo de estudo que mostra como a desmobilização em relação à escola e à aprendizagem não está presente apenas nas camadas mais pobres da sociedade. Através de entrevistas semiestruturadas, a pesquisa da autora apontou que mesmo os jovens de elite manifestavam relações diferenciadas frente ao conhecimento escolar. 
Por fim, a partir da revisão de literatura apresentada nesta seção, podemos aferir que grande parte dos estudos desenvolvidos no campo da juventude e da escola no Brasil utiliza a abordagem de pesquisa qualitativa, com a entrevista como método principal de coleta de dados (DAYRELL, REIS e LEÃO, 2011; DAYREL e MARTINS, 2015; STOSKI e GELBCKE, 2016; ANDRADE, 2015; REIS, 2014). Além disso, há uma predominância de estudos que investigam os jovens estudantes do ensino médio, sendo o estudo de Andrade (2017) o único que investigou alunos do Ensino Fundamental II. Ambos os fatos reafirmam a importância do presente estudo que utiliza a metodologia quantitativa, com aplicação de questionário, para investigar a relação jovens do $9^{\circ}$ ano do Ensino Fundamental com a escola, etapa pouco pesquisada no campo da juventude e da educação no país.

No próximo capítulo, analisaremos outros componentes que perpassam a trajetória dos jovens no ambiente da escola: o clima escolar, a participação e o sentimento de autoeficácia. Como veremos a seguir, esses componentes se relacionam fortemente com os sentidos dado à escola e ao saber pela juventude, portanto, as discussões estabelecidas no tópico seguinte serão centrais para aprofundarmos as reflexões já realizadas ao longo desta seção. 


\section{3. \\ Os jovens no ambiente escolar: clima escolar, participação discente e autoeficácia}

Durante a leitura e análise dos estudos que tratam sobre juventude e escola no campo educacional, três aspectos apareceram de forma recorrente como intermediadores das relações estabelecidas entre os jovens e as escolas: o clima escolar, a participação discente e as crenças de autoeficácia. Sendo assim, dedicamos esse capítulo para apresentação de uma revisão das pesquisas brasileiras e internacionais que discutem sobre como esses três aspectos (clima escolar, participação discente e autoeficácia) perpassam a vida escolar dos jovens.

\section{1.}

\section{Juventude e Clima escolar}

Tendo em vista a falta de consenso sobre a definição de clima escolar e sobre quais dimensões devem ser analisadas para a avaliar a atmosfera de uma instituição, apresentaremos nesta seção apenas duas abordagens sobre o tema, uma internacional (THAPA et al., 2013) e uma nacional (VINHA et al., 2017), como forma de esclarecer o conceito e justificar a utilização de determinadas dimensões na elaboração do nosso instrumento de pesquisa.

Thapa et. al (2013), referência internacional, realizou uma importante revisão de literatura sobre clima escolar que incorporou cerca de 206 trabalhos - dentre eles, estudos experimentais, estudos correlacionais, revisões de literatura e outros estudos descritivos sobre o tema. A partir deste levantamento, os autores elencaram cinco dimensões como sendo essenciais para medir o clima de uma escola: 1) Segurança (regras e normas, segurança física, segurança emocional); 2) Relações interpessoais (respeito à diversidade, engajamento/conexão com a escola, apoio social, liderança, relações entre raça e etnia dos alunos e suas percepções sobre o clima escolar); 3) Ensino Aprendizagem (aprendizado social, emocional, ético e cívico, serviços de aprendizagem; apoio acadêmico, suporte para relacionamentos profissionais, percepção dos professores e alunos sobre o clima da escola); 4) Ambiente institucional (a estrutura física, recursos e suprimentos) e; 5) Processo de melhoria da escola (os esforços dos atores escolares no processo de melhoria da instituição). A partir da revisão elaborada, Thapa et al. (2013) destacaram como 
estudar e pensar em ações para a construção de um clima positivo na escola pode ser uma estratégia viável de melhoria escolar, tendo em vista a capacidade desse componente em prover escolas mais seguras, mais solidárias e mais cidadãs, auxiliar na prevenção do bullying, melhorar o desempenho acadêmico e aumentar as taxas de retenção dos professores.

No Brasil, um estudo que reuniu pesquisadores e pós-graduandos da Faculdade de Educação da Unicamp e do Grupo de Estudos e Pesquisas em Educação Moral (GEPEM) da Unesp/Unicamp resultou na elaboração de questionários para diretores, professores e alunos sobre clima escolar adaptado à realidade brasileira (VINHA et al., 2017). De acordo com os autores o clima escolar pode ser definido como:

(...) o conjunto de percepções e expectativas compartilhadas pelos integrantes da comunidade escolar, decorrente das experiências vividas, nesse contexto, com relação aos seguintes fatores inter-relacionados: normas, objetivos, valores, relações humanas, organização e estruturas física, pedagógica e administrativa, os quais estão presentes na instituição educativa. $\mathrm{O}$ clima corresponde às percepções dos docentes, discentes, equipe gestora, funcionários e famílias, a partir de um contexto real comum, portanto, constitui-se por avaliações subjetivas. Refere-se à atmosfera psicossocial de uma escola, sendo que cada uma possui o seu clima próprio. Ele influencia a dinâmica escolar e, por sua vez, é influenciado por ela e, desse modo, interfere na qualidade de vida e na qualidade do processo de ensino e de aprendizagem. (VINHA et. al., 2017, p. 8).

Os autores elencaram oito dimensões como fundamentais para avaliar o clima das escolas: 1. As relações com o ensino e com a aprendizagem; 2. As relações sociais e os conflitos na escola; 3 . As regras, as sanções e a segurança na escola; 4. As situações de intimidação entre alunos; 5. Família, escola e comunidade; 6. A infraestrutura e a rede física da escola; 7. As relações com o trabalho; 8. A gestão e a participação.

Apesar de não haver uma definição global sobre o tema, as similitudes nas definições de diversos autores (THAPA et al., 2013; VINHA et al., 2017; COHEN et al., 2009; CLARO, 2013) possibilitam o entendimento do clima como sendo um resultado das características individuais de cada instituição, sejam elas objetivas ou subjetivas, e da percepção dos atores acerca dessas características. O clima da escola tende a ser positivo quando os sujeitos que fazem parte da instituição estão de acordo com as práticas daquele ambiente e compartilham com os valores e 
normas presentes na instituição. Por outro lado, um clima negativo pode ser presenciado quando os atores escolares não se identificam com a perspectiva educacional que a instituição adota.

Como muitos estudos apontam (THAPA et. al., 2013; VINHA et. al., 2017; CANGUÇU, 2015; MELO e MORAIS, 2019) a falta de consenso tanto em relação à definição de clima escolar quanto às dimensões que devem ser analisadas, reverbera em limitações nas pesquisas e dificulta a construção de instrumentos confiáveis para analisar o clima. Por outro lado, a importância de estudar e medir esse aspecto dentro das escolas vêm se tornando cada vez mais evidente e os estudos apontam resultados impressionantes associados a um clima escolar positivo, como veremos mais adiante.

\subsection{1.}

\section{As pesquisas brasileiras sobre clima escolar}

Nesta seção será feita uma revisão empírica das pesquisas realizadas nos últimos 10 anos no Brasil que articulam juventude e clima escolar. Para essa revisão, realizamos um levantamento nas plataformas de pesquisa Google Acadêmico, Portal de Periódicos da CAPES e Scielo, utilizando as palavras-chave "clima escolar", "jovens" e "estudantes" com diferentes combinações entre os descritores. A partir da busca realizada foi possível encontrar onze estudos nacionais produzidos nos últimos dez anos sobre o tema. É importante frisar que consideramos como pesquisas associadas à juventude aquelas que envolveram estudantes a partir do Ensino Fundamental II e excluímos as desenvolvidas com alunos do Ensino Fundamental I. Em relação à metodologia, dos onze estudos encontrados, oito são quantitativos (CANDIAN e REZENDE, 2013; REZENDE e CANDIAN, 2013; MELO e MORAIS, 2019; CUNHA, 2014; SILVA e COSTA, 2016; ALCANTARA et al., 2019; COELHO e DELL'AGLIO, 2019; VINHA et al., 2017), dois são qualitativos (DUARTE e OLIVEIRA, 2017; BASTOS, 2019) e um utiliza a abordagem mista (OLIVEIRA, 2015).

Para uma melhor organização dessa revisão, os estudos serão apresentados através de uma categorização dos resultados das pesquisas, sendo assim, primeiramente serão apresentados os estudos que associam o clima escolar com o desempenho do aluno, em segundo lugar, os estudos que associam o clima escolar 
com a segurança da escola e, por fim, os estudos que associam o clima escolar com a satisfação do aluno.

\subsubsection{1.}

\section{Clima Escolar e Desempenho Acadêmico}

O estudo sobre clima escolar teve um grande impulso a partir das pesquisas em eficácia escolar que surgiram em meados dos anos 1970 e buscavam associar as variáveis intraescolares ao desempenho escolar dos alunos (RUTTER et al., 1979; ZULLIG et al., 2010; CANGUÇU, 2015). Cinquenta anos depois, grande parte dos estudos sobre clima seguem buscando comprovar a associação entre clima e desempenho, e a revisão empírica elaborada para esta pesquisa é um exemplo disso: cinco entre os onze estudos selecionados abordavam a relação entre esses dois fatores (CANDIAN e REZENDE, 2013; REZENDE e CANDIAN, 2013; DUARTE e OLIVEIRA, 2017; OLIVEIRA, 2015; MELO e MORAIS, 2019). A razão desse achado pode estar relacionada, também, aos baixos desempenhos acadêmicos dos estudantes brasileiros nas avaliações de larga escala e a preocupação dos pesquisadores em buscar estratégias que possam minimizar esses resultados negativos.

De forma geral, as pesquisas produzidas no Brasil e analisadas nesta seção vêm mostrando que o clima escolar positivo é um grande aliado na melhora do desempenho dos alunos (CANDIAN e REZENDE, 2013; REZENDE e CANDIAN, 2013; DUARTE e OLIVEIRA, 2017; MELO e MORAIS, 2019). O único estudo em que não foi possível encontrar uma associação positiva entre clima e desempenho dos jovens foi o desenvolvido por Oliveira (2015). A autora encontrou associações positivas apenas entre o clima e o desempenho dos alunos do $5^{\circ}$ ano. As hipóteses levantadas por Oliveira (2015) para esse resultado foram de que as características escolares testadas na pesquisa se associavam menos aos resultados dos alunos mais velhos e de que o tamanho reduzido da amostra não revelou a magnitude das relações testadas.

Através da revisão também foi possível observar que algumas dimensões do clima se mostraram mais relacionadas com o desempenho dos alunos do que outras, são elas: Ensino aprendizagem (MELO e MORAIS, 2019; DUARTE e OLIVEIRA, 2017), Normas e regras (MELO e MORAIS, 2019; CANDIAN e REZENDE, 2013; 
DUARTE e OLIVEIRA, 2017) e Segurança (MELO e MORAIS; 2019; DUARTE e OLIVEIRA, 2017).

Por fim, o estudo de Melo e Morais (2019) revelou que o clima escolar não só proporciona melhor qualidade de vida aos membros da escola, mas pode ser um importante aliado na diminuição do impacto da realidade socioeconômica na trajetória escolar dos estudantes. $\mathrm{O}$ estudo das autoras mostrou que escolas com baixo INSE (Indicador de Nível Socioeconômico) tendem a ter um desempenho acima do esperado através da manutenção do clima escolar positivo.

\subsubsection{2.}

\section{Clima Escolar e Segurança}

A relação entre clima escolar positivo e segurança na escola também tem sido amplamente discutido no campo da educação e da saúde. A razão para esse fato pode ser encontrada na amplificação das situações de violência dentro dos espaços escolares nos últimos anos (CHARLOT, 2002). Em nossa busca foram encontrados três artigos publicados nos últimos dez anos no país que tratam sobre a temática, todos utilizando a abordagem quantitativa com aplicação de questionários (CUNHA, 2014; SILVA e COSTA, 2016; ALCANTARA et al., 2019).

Alguns resultados importantes foram encontrados na revisão desses estudos. Nas pesquisas de Silva e Costa (2016) e de Alcantara et al. (2019), o clima escolar positivo foi associado a menores chances de ocorrência de bullying e violência na escola. Além disso, outras pesquisas mostraram que nas escolas em que o bullying, a violência física, o uso de drogas e de bebidas alcóolicas é recorrente, o clima era percebido pelos alunos como negativo (CUNHA, 2014; ALCANTARA et al., 2016). Por fim, outro resultado importante destacado pela pesquisa de Cunha (2014) foi que os jovens negros, do sexo masculino e com menor nível socioeconômico foram os que mais relataram situações de violência e, consequentemente, perceberam o clima como mais negativo dentro da instituição (CUNHA, 2014).

Como constatado nas pesquisas analisadas no tópico anterior, as consequências de pertencer a um lugar inseguro e, por conseguinte, com clima escolar hostil, podem estar relacionadas não apenas a questões socioemocionais, mas também, de desempenho, tendo em vista que escolas com clima escolar negativo tendem a ter resultados inferiores nas avaliações de larga escala. 


\subsubsection{3. \\ Clima escolar e satisfação do aluno}

Também foram encontrados três estudos que buscavam verificar a relação entre um clima escolar positivo e a satisfação do aluno em estudar na sua escola (COELHO e DELL'AGLIO, 2019; VINHA et al., 2017 e BASTOS, 2019). Sobre a metodologia utilizadas nas pesquisas, duas são de caráter quantitativo (COELHO e DELL'AGLIO, 2019; VINHA et al., 2017) e uma qualitativa (BASTOS, 2019).

No que se refere aos resultados dos estudos, a pesquisa de Coelho e Dell'Aglio (2019) apontou que a dimensão "Relacionamento professor-estudante" explicou $25 \%$ da variação do clima escolar, na visão dos alunos. Em contrapartida, as dimensões "Bullying", "Segurança na escola" e "Engajamento estudantil" não se mostraram tão significativos para explicar a satisfação do aluno em relação ao ambiente escolar.

No que se refere à pesquisa de Vinha et al. (2017) os autores buscaram verificar quais eram as percepções dos alunos sobre oito dimensões do clima escolar. Os resultados apontaram que a dimensão "As situações de intimidação entre alunos" foi a que teve uma avaliação mais positiva pelos alunos, seguida por "As regras, sanções e a segurança na escola”, “As relações sociais e os conflitos na escola" e "As relações com o ensino e a aprendizagem". Em contrapartida, as dimensões que tiveram as piores avaliações foram "A família, a escola e a comunidade" e "A infraestrutura e a rede física da escola". No estudo de Bastos (2019) que avaliou as mesmas dimensões de Vinha et al. (2017), mas em uma escola considerada democrática, apenas as dimensões "A relação da família com a escola" e "A infraestrutura e rede física da instituição" foram avaliadas de forma negativa pelos atores escolares. Bastos (2019) concluiu que, nessa escola pesquisada, a existência de um modelo de gestão democrática se relacionava com um clima escolar positivo.

As pesquisas analisadas nesta subseção são importantes pois indicam quais dimensões do clima escolar vêm sendo avaliadas pelos alunos como mais positivas ou negativas em suas escolas. Mais adiante, será possível contrastar esses achados com os obtidos através da aplicação do nosso instrumento. 


\subsection{2.}

\section{Os estudos internacionais sobre clima escolar}

Tendo em vista o pioneirismo nos estudos americanos e europeus sobre clima escolar e, portanto, a vasta quantidade de pesquisas internacionais sobre o tema, optamos por selecionar onze pesquisas publicadas nos últimos dez anos, número semelhante à revisão nacional. Para a busca utilizamos os descritores "school climate", "youth", "students" nas plataformas de pesquisa Google Acadêmico, Scielo e Portal de periódicos da CAPES. Para a seleção dos estudos no Google Acadêmico, plataforma de pesquisa que encontramos mais resultados, ordenamos as pesquisas pelo filtro "mais relevantes", analisamos os resumos dos artigos que apareceram até a página cinco da plataforma e selecionamos aqueles que dialogavam com aspectos da vida escolar também vistos na literatura brasileira (como desempenho e segurança) e outros inéditos (como empoderamento e evasão). Nas demais plataformas de pesquisa, Scielo e Portal de periódicos da CAPES, utilizamos os filtros "mais relevantes" e "mais citados" e utilizamos os mesmos critérios de seleção.

A revisão, assim como na seção anterior, será apresentada por temática: clima escolar e desempenho, clima escolar e diferenças socioeconômicas, clima escolar e segurança, clima e empoderamento e clima escolar e evasão.

\subsubsection{1.}

\section{Clima escolar e desempenho}

Os dois estudos selecionados para esta subseção utilizam a abordagem quantitativa para as suas análises e discutem a centralidade do papel do diretor na construção de um clima escolar positivo e na melhora do desempenho dos alunos (MACNEIL, PRATER e BUSCH, 2009; QUIN et al., 2015). Em ambos os estudos, o clima escolar foi medido através da aplicação de questionários aos atores escolares.

MacNeil, Prater e Busch (2009) buscaram investigar se escolas com desempenhos diferentes na avaliação nacional do Texas diferiam em termos de clima escolar. Os resultados do estudo apontam a influência do diretor na construção do clima positivo e, consequentemente, na melhora dos resultados dos alunos. Nesta pesquisa os autores encontraram que, quando os diretores interagem 
com o clima da escola criando metas claras para a instituição e mantendo a estabilidade enquanto responde às demandas do ambiente externo, o aprendizado dos alunos tende a melhorar (MACNEIL, PRATER E BUSCH, 2009).

Outro estudo desenvolvido por Quin et al. (2015) buscou encontrar as correlações entre as práticas de liderança do diretor, cultura escolar e desempenho dos alunos. Os autores utilizam o termo "cultura escolar" em seu estudo, no entanto, como mencionado anteriormente, a falta de definição sobre o que seria "clima escolar" e as suas dimensões faz com que muitos autores utilizem outros termos, como o caso da cultura, para falar sobre o que entendemos como clima. Os resultados da pesquisa apontaram que havia uma correlação significativa entre as práticas de liderança do diretor e todos os aspectos da cultura escolar avaliados no estudo. Além disso, foi encontrada uma correlação positiva e significativa entre o clima escolar e o desempenho dos alunos, principalmente na dimensão "parceria de aprendizagem", que se refere ao trabalho em conjunto dos diretores, professores e pais, para a melhoria da performance e desempenho dos alunos.

\subsubsection{2. \\ Clima escolar e características socioeconômicas dos alunos}

As pesquisas discutidas nesse tópico buscam analisar as relações entre clima escolar e características socioeconômicas. Em geral, elas buscam aferir se há diferenças na percepção sobre o clima escolar entre os distintos grupos socioeconômicos. Os dois estudos encontrados sobre a temática utilizam a metodologia quantitativa, com aplicação de questionário aos jovens participantes (DE PEDRO, GILREATH e BEKOWITZ, 2016; SHUKLA, KONOLD e CORNELL, 2016).

A pesquisa desenvolvida por De Pedro, Gilreath e Berkowitz (2016) apontou que os estudantes não-brancos eram aqueles que percebiam o clima como mais negativo nas dimensões avaliadas pelo estudo (qualidade nos relacionamentos, conexão com a escola, segurança e participação). De acordo com os autores, uma razão para esse achado pode estar relacionada com o fato dos estudantes negros estarem mais frequentemente em escolas e distritos públicos com recursos pessoais e financeiros limitados, que impedem a implementação de programas de clima escolar. Além disso, como mostraram algumas pesquisas, as comunidades escolares 
de negros e latinos têm, em média, taxas significativamente mais altas de rotatividade de professores e diretores, de suspensão e expulsão, de evasão escolar e de participação em gangues, fatores que afetam o clima da escola (DE PEDRO; GILREATH; BERKOWITZ, 2016).

Outro resultado importante apontado pela pesquisa foi que estudantes de níveis mais altos de ensino tendem a ter percepções mais negativas sobre o clima escolar e isso, de acordo com os autores, pode ser explicado pela própria estrutura das escolas de ensino médio que tendem a ter um número maior de professores lecionando as disciplinas e ambientes mais amplos, fatores que dificultam a construção de relações mais profundas com os demais atores escolares (DE PEDRO; GILREATH; BERKOWITZ, 2016).

Outro estudo desenvolvido por Shukla, Konol e Cornell (2016) converge com os achados de De Pedro, Gilreath e Berkowitz (2016) e apontam que há distinção na percepção sobre o clima entre os alunos de diferentes grupos sociais. Sendo assim, estudantes afro-americanos e com pais menos escolarizados tendiam a ter percepções mais negativas sobre o clima escolar. Além disso, o estudo constatou que os alunos com percepções mais positivas sobre o clima escolar também tiveram notas mais altas nos exames e maiores aspirações acadêmicas, já os estudantes com percepções mais negativas obtiveram maiores taxas de porte de arma, brigas, tentativas de suicídio e uso de álcool e maconha.

Estudos como esses elaborados por Shukla, Konold e Cornell (2016) e De Pedro, Gilreath e Berkowitz (2016) são de extrema importância pois, grande parte dos estudos, apenas avaliam o clima escolar através da média das percepções dos atores sobre a instituição e não se atentam para a especificidade de cada aluno e para os padrões dessas percepções, fato tão importante para pensarmos em ações e políticas mais direcionadas para as necessidades de cada grupo.

\subsubsection{3.}

\section{Clima escolar e segurança}

Nessa seção analisamos os estudos que buscaram relacionar o clima escolar com as situações de violência (física e emocional) nas instituições. No total, foram selecionados quatro estudos para esta subseção. Todos os estudos utilizaram métodos quantitativos para a análise dos resultados obtidos através da aplicação de 
questionários aos alunos (FERRÁNS, 2014; KLEIN, CORNELL e KONOLD, 2012; BECERRA, MUNOZ e RIQUELME, 2015; MATA et al., 2015).

No que se refere aos resultados das pesquisas, Klein, Cornell e Konold (2012) encontraram uma associação entre clima escolar positivo e níveis mais baixos de envolvimento dos alunos em comportamentos de risco, como fazer bullying e protagonizar agressões (KLEIN, CORNELL e KONOLD, 2012). O estudo de Mata et al. (2015) salientou a influência do clima escolar na dimensão "relações interpessoais" no desenvolvimento de emoções mais positivas ou negativas dentro do ambiente de sala de aula. Por fim, os estudos de Ferrans (2014) e Becerra, Munoz e Riquelme (2015) destacaram a importância de os alunos participarem ou estarem a par da criação e estabelecimento das regras da escola para a diminuição das situações de violência na escola, tendo em vista a importância do compartilhamento dos valores para a criação de um clima escolar mais saudável.

\subsubsection{4. \\ Clima escolar e empoderamento}

O único trabalho encontrado sobre o tema foi elaborado por Kirk et al. (2017) e buscou analisar como determinadas características do ambiente escolar e da sala de aula podem facilitar o empoderamento dos estudantes. O empoderamento, segundo Kirk et al. (2017, p. 829), “é um processo pelo qual os alunos ganham poder necessário para atender suas necessidades individuais (por exemplo, aprendizagem, relações sociais, diploma) e trabalhar com os outros (alunos, professores, administradores) para atingir objetivos coletivos (um ambiente escolar seguro e positivo) ".

A partir de um estudo de caso, Kirk et al. (2017) encontraram cinco dimensões do clima de sala de aula que colaboravam para o empoderamento dos alunos: a crença do professor no sucesso dos alunos, sentido de comunidade na sala de aula, papeis equitativos entre professores e alunos, práticas envolventes em sala de aula e tomada de decisão compartilhada. No que se refere às características do ambiente escolar, sete dimensões do clima foram identificadas: tradições positivas (identificação com as tradições e as práticas da escola), valorização da liderança estudantil, acolhimento da diversidade cultural, recursos adequados, capacitação de professores (enfatizando a voz do professor e criando oportunidades de influência) 
e sentido de comunidade na equipe. Dessa forma, a pesquisa reafirmou que ambientes seguros e de apoio, nos quais há participação significativa e poder compartilhado, são mais capazes de criar oportunidades para que os jovens controlem o processo da sua educação.

\subsubsection{5.}

\section{Clima escolar e evasão}

Orpinas et al. (2016) em um estudo longitudinal que abrangeu 638 estudantes da Geórgia (EUA) buscou analisar a relação do clima escolar e a decisão, por parte dos alunos, de abandonar a escola. Os resultados da pesquisa apontam que havia diferenças significativas acerca da percepção sobre o clima escolar entre aqueles que permaneceram na escola e os que optaram por evadir da instituição. Como os autores esperavam, em comparação com os alunos que não evadiram, os alunos que evadiram relataram vivenciar maior vitimização (aberta e relacional), relacionamentos menos positivos com seus pares, menor conexão com a escola, menos interação com os adultos da escola e uma participação menos significativa no espaço escolar. Após uma análise de regressão realizada pelos autores, foi constatado que as variáveis que mais se apresentaram estatisticamente significativas para explicar o abandono escolar foram: ser menino, sofrer vitimização relacional, ter menos conexão com a instituição e ter menos adultos atenciosos na escola (ORPINAS et. al, 2016).

Através das pesquisas discutidas ao longo desta seção, foi possível perceber como o clima escolar é capaz de influenciar na trajetória escolar dos alunos, inclusive na sua decisão em abandonar ou prolongar seus estudos (ORPINAS et. al, 2016). Na próxima seção deste capítulo, discutimos a relação dos jovens com a escola no que se refere à participação desse grupo no ambiente escolar. Alguns estudos trabalhados ao longo desta seção apontaram que a participação pode estar relacionada ao clima de diferentes formas: como uma dimensão dentro do construto (CADIAN; REZENDE, 2013b; DUARTE; OLIVEIRA, 2017; MELO; MORAIS, 2019) ou como um fator que gera determinado tipo de clima dentro das instituições (KIRK et al., 2017). No presente estudo, decidimos analisar a participação e o clima escolar separadamente, por razões explicitadas a seguir. 


\section{2. Juventude e Participação}

Os estudos sobre clima escolar e participação discente estão muitas vezes conectados e interligados por uma rede de causa e efeito, por esse motivo, muitos estudos que tratam sobre clima escolar consideram a participação como uma das dimensões chave para medir a atmosfera da escola (CADIAN e REZENDE, 2013; DUARTE e OLIVEIRA, 2017; MELO e MORAIS, 2019). Apesar disso, no presente estudo e para a construção do questionário, decidimos analisar os dois conceitos separadamente, com o intuito de olhar para cada um deles de forma mais aprofundada e, posteriormente, desenvolver análises relacionando os dois construtos.

Na revisão bibliográfica desta seção buscamos analisar os estudos nacionais e internacionais elaborados nos últimos dez anos que tratam sobre a participação da juventude na escola. A revisão foi realizada nas plataformas de pesquisa Google Acadêmico, nos sites do Observatório Jovem da UFF (Universidade Federal Fluminense) e do Observatório da Juventude da UFMG (Universidade Federal de Minas Gerais), no Portal de Periódicos e de dissertações da CAPES e no Scielo. No contexto brasileiro, foram utilizadas as palavras-chave: juventude + escola + participação; participação discente e, no contexto internacional, utilizamos os descritores student voice; student participation; school leadership + youth. Os resultados da pesquisa serão apresentados a seguir.

\subsection{1.}

\section{Os estudos brasileiros sobre juventude e participação.}

No Brasil, os termos "participação" e "protagonismo juvenil" são os mais utilizados nas pesquisas que tratam as práticas de inclusão dos alunos nas tomadas de decisões sobre aspectos da vida escolar. O termo "protagonismo juvenil" está presente como um princípio fundamental nas Diretrizes Curriculares Nacionais para o Ensino Médio, com o objetivo de destacar a importância da participação dos jovens no desenvolvimento das atividades escolares, atribuindo ao professor a função mais de orientar o aluno do que propriamente ensinar. Por outro lado, esse mesmo termo vem sofrendo críticas de alguns pesquisadores, que afirmam que ele estaria associado a políticas neoliberais que transferem para as crianças e para os jovens a responsabilidade de superação das suas adversidades e desloca para a 
sociedade civil funções que cabem ao Estado (FERRETTI, ZIBAS E TARTUCE, 2004). No caso desta pesquisa, optamos por utilizar o termo "participação" por entender que ele se adequaria mais a nossa proposta de pesquisa e que os estudos brasileiros que utilizam o termo conversam mais com o nosso objeto de estudo.

Durante a nossa revisão foram encontrados seis estudos nacionais publicados nos últimos dez anos que tratam da participação da juventude no espaço escolar, sendo quatro qualitativos (MARTINS e DAYRELL, 2013; CORTI, CORROCHANO e SILVA, 2016; CATININI e MELLO, 2016; ARELARO, JACOMIE e CORNEIRO, 2016), um quantitativo (DAYRELL, GOMES e LEÃO, 2010) e um com abordagem mista (ROMANCINI e CASTILHO, 2017).

Sobre a temática dos estudos, podemos dizer que eles discutem, principalmente, o papel formativo dos espaços de participação presentes nas escolas e os obstáculos ainda existentes para a efetivação desses mecanismos de participação no ambiente escolar. Dentre os principais obstáculos mencionados pelos autores estão a falta de reconhecimento das oportunidades de aprendizagem que estão presentes nos espaços de participação, os padrões hierárquicos já estabelecidos e naturalizados que ocasionam estranhamentos quando os alunos protagonizam determinados movimentos, e a noção de tempo da escola, sempre rígida e programada, que destoa da lógica da participação dos jovens (DAYRELL, REIS e LEÃO, 2010; MARTINS e DAYRELL, 2013; CANTINI e MELO, 2016). De acordo com Dayrell, Gomes e Leão (2010), o afastamento da juventude dos espaços de participação social e política nos âmbitos extraescolares pode ser justificada pela ausência de oportunidades oferecidas pela escola nas quais eles possam vivenciar a experiência participativa e reconhecer os resultados da ação coletiva.

Por outro lado, a importância de existir espaços de participação no ambiente escolar está relacionada às oportunidades para o exercício do diálogo, da escuta, do respeito à opinião do outro e da responsabilidade para a juventude. De acordo com os autores que discutem sobre o tema, os momentos de tensões e conflitos que ocorrem quando os estudantes não convergem sobre as decisões que devem ser tomadas são ricos para o desenvolvimento do senso crítico e de aprendizagem sobre a vida em sociedade (MARTINS e DAYRELL, 2013; CORROCHANO e SILVA, 2016; CANTINI e MELO, 2016). 
Outro tema encontrado em nossa revisão foi a discussão sobre os movimentos de ocupações dos estudantes secundaristas que ocorreu em 2015 e que se tornou um marco na luta estudantil que parecia estar adormecida há algum tempo (ROMANCI e CASTILHO, 2017; CORTI, CORROCHANO e SILVA, 2016; CANTINI e MELO, 2016; ARELARO; JACOMI e CARNEIRO, 2016).

O movimento de ocupações de escolas da rede pública de Ensino Médio realizadas pelos estudantes em 2015, que tiveram início em São Paulo e se propagaram em 2016 para outros estados brasileiros, tinha como principal objetivo questionar as decisões de política educacional dos estados, sobretudo no que dizia respeito ao fechamento de unidades escolares no bojo de propostas de racionalização da gestão educacional. O estopim para o início da luta dos secundaristas foi o fechamento imediato de quase cem escolas do Estado de São Paulo, impactando mais de 310 mil alunos. De acordo com os secundaristas, essa reorganização do ensino levaria à super lotação das salas de aulas, dificultaria o acesso dos estudantes às escolas mais próximas das suas residências e romperia o vínculo criado com o espaço escolar. A força da luta dos estudantes resultou na suspensão da política de reorganização escolar e no afastamento do Secretário de Educação do governo, Herman Voorwald (CATINI e MELO, 2016; CORTI, CORROCHANO e SILVA, 2016).

Dada a relevância e abrangência das ocupações estudantis de 2015, no ano de 2016 a Revista Educação e Sociedade de Campinas organizou dossiê denominado "Políticas Educacionais e Resistência Estudantil" que reuniu pesquisas de diversos autores acerca dos movimentos de ocupação dos jovens secundaristas. Para a elaboração desta revisão, foram lidos três estudos que compõem esse dossiê, sendo todos eles pesquisas qualitativas que utilizaram como fonte de coleta de dados alguns jornais, revistas, documentos legais, publicações em redes sociais, entrevistas com secundaristas, observações das ocupações e trabalhos acadêmicos já publicados.

O primeiro artigo, de Arelaro, Jacomini e Carneiro (2016), buscou analisar o histórico jurídico-político da gestão democrática e as políticas de educação implementadas no Estado de São Paulo desde 1995. Ao longo do trabalho, os autores discutiram como caminho para a democratização dos espaços escolares ainda é longo no Brasil. De acordo com os autores, a falta de objetividade e clareza na redação das leis sobre quais seriam os princípios e obrigações de uma gestão 
escolar democrática é o principal empecilho para a execução desse modelo de gestão nos espaços institucionais.

Os dois outros trabalhos publicados no dossiê "Políticas Educacionais e Resistência Estudantil" da Revista Educação e Sociedade de Campinas foram elaborados por Corti, Corrochano e Silva (2016) e Cantini e Melo (2016). Ambos os estudos destacaram a importância dos atos no processo de formação política e social dos secundaristas. Em primeiro lugar, a autogestão dessas ocupações foi apontada como sendo potencialmente educativa para os jovens. Os estudantes criaram comissões responsáveis pelo cotidiano das ocupações que realizavam tarefas de alimentação, limpeza, comunicação externa e interna, planejamento de assembleias, gestão de conflitos, entre outras categorias que tornavam a vivência dentro das ocupações mais democráticas (CORTI; CORROCHANO; SILVA, 2016; CANTINI e MELO, 2016). Outro ponto destacado pelos autores foram os relatos de alguns jovens que declararam terem aprendido mais em alguns dias de ocupação do que em anos dentro da sala de aula. A agenda cultural das ocupações que continham desde aulas públicas, oficinas, cursinhos pré-vestibular até shows e saraus, demonstraram o desejo dos jovens por uma escola e por uma aula com formatos diferenciados do tradicional. De acordo com Corti, Corrochano e Silva (2016),

As ocupações trouxeram materialidade às críticas e frustrações que vêm sendo documentadas pela literatura a respeito da relação dos jovens com a escola. A pouca resposta das políticas educacionais aos anseios juvenis - e a presença crescente desse público nas escolas - deve ter colaborado para a eclosão do conflito. As imagens oferecidas pelos jovens nas ocupações atuando, discursando, cozinhando e limpando - contrastam com as imagens tradicionais de estudantes calados e enfileirados nas salas de aula.

Outro ponto que foi considerado nos trabalhos de Corti, Corrochano e Silva (2016) e Cantini e Melo (2016) foram as novas formas de organização e mobilização da juventude no contexto atual, caracterizadas por um movimento híbrido, que se inicia nas redes sociais, mas não se afasta do real. Dessa forma, os jovens de hoje tendem a utilizar a internet para manifestarem os seus posicionamentos e lutas, mas isso não significa que eles estão afastados dos espaços físicos de reinvindicação, como as ruas e as próprias instituições de ensino. 
Essa forma de manifestação da juventude contemporânea também foi bem explorada pelo trabalho produzido por Romancini e Castilho (2017). Nesse estudo, os autores buscaram analisar o uso das mídias no contexto das ocupações estudantis do estado de São Paulo através de uma abordagem quantitativa (quantidade de postagens, localização) e qualitativa (análise de conteúdo, grupos focais e entrevistas). Romancini e Castilho (2017) destacaram ao longo do trabalho a importância de a escola promover e estimular a política participativa, pois, dessa forma, é possível qualificá-la e contornar os possíveis limites e riscos dessa participação (como o envolvimento apenas dos estudantes das camadas mais privilegiadas, a expressão de ideias incoerentes e o uso de discursos de ódios nas manifestações).

Por fim, como estamos falando do Brasil, é importante considerar que a participação, ou não, dos jovens nas decisões da escola também está relacionada com outros aspectos da relação da juventude com o espaço escolar. Ainda que a escola ofereça espaços de participação, a vontade de participar e se engajar nas questões da vida escolar perpassa fatores intra e extraescolares.

Em relação aos fatores extraescolares, eles estão relacionados ao contexto social e econômico dos jovens que estão presentes nas instituições de ensino público do país. Como já citado, a entrada da juventude menos favorecida na escola ainda é recente e apresenta muitos desafios para o ensino público brasileiro. Grande parte dos jovens, principalmente dos últimos anos do Ensino Fundamental e do Ensino Médio, têm outras ocupações para além da vida de estudante, como o trabalho e o cuidado da família. Participar mais ativamente nas decisões e na vida escolar requer uma disponibilidade de tempo que muitos jovens não têm, já que possuem demandas extraescolares. Esse limite para a participação pesa mais quando percebemos, como apontado em alguns trabalhos (MARTINS; DAYRELL, 2013; LEÃO e SANTOS, 2018), que a escola estigmatiza os alunos que participam desses coletivos, não disponibiliza tempo para as reuniões e não oferece espaços atrativos para que os estudantes sintam vontade de participar.

Além disso, as tensões que se referem ao sentido dado à escola pelos jovens e a distância dos conteúdos escolares do interesse do jovem, aspectos tratados no capítulo 2, também podem afastar e inibir a vontade do jovem participar mais ativamente do espaço escolar. Afinal, querer mudar e melhorar o ambiente em que estuda pode estar vinculado a um sentimento de pertencimento e valorização desse 
espaço. Por outro lado, os movimentos de ocupação presenciados nos últimos anos cultivam a esperança da juventude ter interesse em se engajar nas causas da educação pública e lutar pelos direitos que são, indiscutivelmente, seus.

\subsection{2.}

\section{Os estudos internacionais sobre juventude e participação}

$\mathrm{Na}$ literatura internacional, os estudos e pesquisas que tratam sobre a participação da juventude no espaço escolar também vêm ganhando espaço nos últimos anos, principalmente no que se refere à literatura que trabalha com o conceito de "student voice". Traduzindo para a língua portuguesa, student voice seriam as iniciativas por parte da escola de amplificar a voz do aluno e dar oportunidade para que eles possam colaborar com as decisões da escola que dizem respeito a eles e aos seus colegas. De acordo com Dana Mitra, uma das principais autoras do campo e fundadora do International Jornal of Student Voice, essas iniciativas são muito importantes para que os jovens aprendam princípios democráticos, compartilhando as suas opiniões e melhorando as condições escolares para si e para os outros (MITRA e GROSS, 2009).

Ao longo da nossa revisão de literatura internacional, foram encontrados sete estudos empíricos que discutiam a questão da participação discente no espaço escolar, com predominância de estudos qualitativos (MITRA, SERRIERE e STOICOVY, 2012; THOMPSON, 2009; KANE e CHIMWAYANGE, 2014; ROBINSON e TAYLOR, 2013), seguido por estudos com abordagem quali-quanti (MITRA e GROSS, 2009; JONES e BUBB, 2020) e um único quantitativo (LEEK, 2019). Também foi possível verificar que todos os estudos analisados buscavam associar a maior participação do aluno no espaço escolar com melhorias no espaço escolar.

De acordo com Mager e Nowak (2012), existem duas correntes principais quando se fala da participação discente. A primeira destaca a importância dessas ações para a formação cidadã dos alunos, já que a partir delas os jovens podem desenvolver "conhecimentos, habilidades e atitudes que lhes permitam assumir um papel informado e ativo na sociedade democrática" (MAGER e NOWAK, 2012, p. 39). E a segunda corrente entende que os mecanismos de amplificação das vozes discentes são importantes para a melhoria da escola, tendo em vista que a participação dos alunos nas decisões escolares pode favorecer o seu engajamento 
na instituição, tornar o processo de ensino e aprendizagem mais significativos e, inclusive, melhorar o desempenho dos alunos. Na revisão de literatura internacional realizada para este trabalho foi encontrado uma predominância de estudos localizados na segunda corrente, que buscam associar a participação discente a melhorias do ambiente escolar.

Dentre os principais resultados associados à amplificação da voz do aluno no espaço escolar estão o aperfeiçoamento do processo de ensino e aprendizagem a partir da contribuição dos alunos nas dinâmicas de sala de aula (MITRA e GROSS, 2009; THOMPSON, 2009; KANE e CHIMWAYANGE, 2014), o maior sentimento de pertencimento do aluno no espaço escolar (MITRA e GROSS, 2009), a melhora nas relações entre professores e alunos (THOMPSON, 2009; KANE e CHIMWAYANGE, 2014), a melhora da disciplina em sala de aula (THOMPSON, 2009), o maior engajamento dos alunos nas aulas (KANE e CHIMWAYANGE, 2014) e, por fim, a melhoria no desempenho escolar (LEEK, 2019).

Contudo, assim como os estudos brasileiros, as pesquisas internacionais também destacam os obstáculos enfrentados para tornar o ambiente escolar mais democrático através da participação dos alunos. De acordo com Mitra et al. (2012) e Jones e Bubb (2020), um dos maiores desafios para a amplificação da voz dos alunos seriam as relações hierárquicas estabelecidas no ambiente escolar e que dificultam o entendimento, por parte dos adultos, do aluno como um parceiro ativo na mudança da instituição. Jones e Bubb (2020) também salientaram que o medo do professor de receber críticas sobre o seu trabalho e o pouco tempo disponível foram aspectos citados pelos docentes como dificultadores para a realização de ações mais participativas no espaço escolar. Por fim, Robinson e Taylor (2013) destacam que, ainda que a instituição possua projetos de amplificação da voz dos alunos, as relações de poder podem estar presentes de forma oculta dentro desses projetos, como, por exemplo, na imposição para a realização dessas ações por parte dos diretores ou na mudança de comportamento dos alunos quando participam de tais ações.

Por fim, é importante destacar que o campo dos estudos sobre student voice também é palco de disputas e alguns autores tecem críticas acerca dos estudos que buscam associar a amplificação da voz dos alunos a melhorias de desempenho MAGER e NOWAK, 2012, BUBB e JONES, 2020; FIELDING, 2004). Para eles, as ações de participação discente devem ter como objetivo principal a formação 
integral do indivíduo para a sociedade e não servir como mais um mecanismo de melhora de performance e desempenho do aluno (MAGER e NOWAK, 2012, BUBB e JONES, 2020; FIELDING, 2004;). Sobre esse aspecto o Fielding (2001, p. 100, minha tradução) destaca:

Estamos testemunhando o surgimento de algo genuinamente novo, estimulante e emancipatório que se baseia em ricas tradições de renovação e transformação democrática? ... Ou estamos presidindo o aprofundamento das suposições e intenções existentes, usando a voz do aluno ou aluno como um mecanismo adicional de controle?

O que foi possível perceber ao longo desta revisão de literatura nacional e internacional é que, no Brasil, há uma tendência de buscar compreender a importância da participação discente para a formação do indivíduo como sujeito crítico e mais capacitado para atuar na sociedade, enquanto os estudos internacionais tentam compreender como os mecanismos de participação estudantil podem ser efetivos para a melhoria de diversos aspectos do ambiente escolar e da trajetória dos alunos.

\section{4 . Juventude e Autoeficácia}

Assim como os temas analisados nas seções anteriores, a autoeficácia tem recebido importante atenção na área da educação. De acordo com Bandura (1997), um dos principais referenciais teóricos dentro do campo, o termo pode ser compreendido como um julgamento pessoal das próprias capacidades de exercer controle sobre o seu desempenho em determinadas situações e eventos que afetam a sua vida. Segundo o autor, essa crença influencia como as pessoas se sentem, pensam, se motivam e se comportam (BANDURA, 1997, p. 118). Uma importante característica da autoeficácia é o fato dela poder ser desenvolvida ao longo do tempo, a partir de determinadas ações e condutas que tornam as pessoas mais confiantes em relação as suas capacidades de executar e ter controle as suas tarefas (BANDURA, 1993).

A autoeficácia, portanto, é um construto individual que, diferente do clima e da participação, indica como os jovens se sentem sobre eles mesmos e não em relação ao espaço escolar. No entanto, ela tem forte relação com os temas discutidos anteriormente (a mobilização em relação à escola, o clima escolar e a participação), 
tendo em vista que é um construto que não apenas influencia a forma como os alunos se relacionam com a escola, mas também é influenciado pela forma como a instituição se organiza. Um exemplo disso pode ser visto nos estudos que associam um ambiente participativo (MANGANELLI et al, 2015; BUTZ e USHER, 2015), a disponibilidade de apoio dos professores e o estilo de ensino adotado por eles como fontes de autoeficácia acadêmica (BUTZ e USHER, 2015). Esses resultados mostram que as características da escola, como o clima e o nível de participação, podem influenciar fortemente das crenças de autoeficácia dos alunos.

Bandura (2006) atenta para o fato de que essas crenças têm uma centralidade ainda maior para jovens e adolescentes. Na juventude, os sujeitos precisam gerenciar transições de papéis do ponto de vista biológico, social e educacional. O jovem está presente em diferentes espaços sociais e, dentro deles, está constantemente avaliando as suas capacidades para executar as tarefas requeridas, seja como aluno, como amigo, como cidadão ou como filho. Na maior parte das vezes, não é possível lidar com todos esses papeis de forma equilibrada, o que faz com que a crença de autoeficácia dos jovens se modifique de acordo com o papel que eles estão assumindo. Como destaca Azzi, Guerreiro-Casanova e Dantas (2010, p. 55), “a autoeficácia é uma crença dinâmica, dessa forma, é possível se sentir altamente eficaz para executar determinada tarefa em um momento específico e se sentir completamente incapaz de cumprir outra".

No caso da presente pesquisa, optamos por analisar os estudos que discutem dois tipos de autoeficácia: a autoeficácia acadêmica e a autoeficácia para decisões de carreira. De acordo com Bandura (1993), a autoeficácia acadêmica se refere as convicções pessoais sobre as capacidades relacionadas às demandas específicas do cotidiano e das atividades escolares. Optamos por analisar os estudos que tratam sobre o tema pois o principal objetivo desta pesquisa é conhecer a relação da juventude com a escola e diversos estudos apontam a influência da autoeficácia acadêmica em diferentes aspectos da trajetória escolar dos estudantes. No que se refere à autoeficácia para decisões de carreira, Aguillera (2013) define como a percepção dos jovens sobre as suas capacidades de organizar, planejar e decidir os seus rumos no mercado de trabalho. Dada a centralidade do trabalho na vida dos jovens, já constatadas pelas pesquisas apresentadas no capítulo 2, acreditamos que os estudos que trabalham sobre esse tipo de autoeficácia trarão contribuições 
significativas para a elaboração do instrumento e para a análise dos resultados desta pesquisa.

Nossa revisão de pesquisa sobre juventude e autoeficácia abrangeu os estudos presentes nas plataformas Google acadêmico, Portal de periódicos da CAPES e Scielo que foram encontrados através das palavras-chave: juventude + autoeficácia; autoeficácia acadêmica; students + self efficacy; youth + self efficacy; academic self efficacy. Devido à quantidade de estudos que resultaram da nossa busca, no contexto nacional foi realizado um recorte de 10 anos e no contexto internacional (em que esse campo de estudo é mais difundido), fizemos um recorte dos últimos 5 anos. Para a seleção dos estudos internacionais, além do período de tempo, utilizamos alguns filtros nas plataformas de pesquisa como "mais relevantes" e "mais citados" e escolhemos as pesquisas que se mostraram mais pertinentes para a elaboração do instrumento de pesquisa e, posteriormente, para a discussão dos nossos resultados.

\subsection{1. \\ Os estudos sobre autoeficácia e juventude no Brasil}

Em nossa revisão foram encontrados cinco estudos brasileiros que tratam sobre autoeficácia acadêmica ou de carreira dos jovens, todos utilizando metodologias quantitativas com aferição das crenças de autoeficácia através da aplicação de questionários (AZZI, GUERREIRO-CASANOVA e DANTAS, 2010; GUERREIRO-CASANOVA, AZZI e DANTAS, 2011; LEAL et al., 2015; OLIVEIRA e SOARES, 2011; EL ACHKAR et al., 2017).

A pesquisa elaborada por Azzi, Guerreiro-Casanova e Dantas (2010) buscou medir a percepção dos estudantes acerca das suas habilidades em situações que envolvem os processos de ensino aprendizagem, as condições de estudo e o desempenho. No geral, o estudo desenvolvido por Azzi, Guerreiro-Casanova e Dantas (2010) apontou que os estudantes pesquisados acreditavam nos seus potenciais em aprender os conteúdos das disciplinas e terminar os trabalhos da escola, mas se sentiram pouco capazes de utilizar algumas estratégias que são importantes para a aprendizagem, como revisar os conteúdos das disciplinas e pedir ajuda aos colegas caso tenham dúvidas.

Outros itens que também obtiveram uma média baixa de percepção de autoeficácia foram: contribuir com ideias para a melhoria da escola e buscar 
informações sobre a estrutura e recursos da escola que frequento. Azzi, GuerreiroCasanova e Dantas (2010) destacaram que esse resultado pode estar relacionado ao distanciamento do jovem do espaço escolar e a ausência de ações que coloquem o jovem em lugares de protagonismo e agente de mudança dentro do ambiente escolar, como a própria Lei de Diretrizes e Bases do Ensino Médio propõe (ZIBAS, FERRETTI e TARTUCE, 2006). As crenças de autoeficácia nas situações de liderança e protagonismo precisam ser desenvolvidas a partir de projetos e atitudes que desenvolvam as capacidades e habilidades dos alunos em atuar em determinadas situações (AZZI, GUERREIRO-CASANOVA e DANTAS 2010).

Apesar da escola ser um dos principais espaços responsáveis por conferir e desenvolver determinadas habilidades nos jovens, os estudos apontam que a família tem um papel central na construção dessas crenças e influenciam fortemente no desenvolvimento delas (BANDURA, 1997). Nesse sentido, outro estudo de Guerreiro-Casanova, Azzi e Dantas (2011) analisa a influência da escolaridade dos pais nas crenças de autoeficácia em alunos do Ensino Médio.

Para a análise dos resultados, os autores subdividiram a autoeficácia acadêmica em algumas categorias: autoeficácia para aprender, autoeficácia para atuar na vida escolar e autoeficácia para decisão de carreira. Em relação aos resultados, com exceção da categoria autoeficácia para decisão da carreira, todas as outras categorias se mostraram significativamente relacionadas com a escolaridade das mães e dos pais dos alunos, ainda que não tenha sido possível observar tendências tão marcadas nessas relações. Guerreiro-Casanova, Azzi e Dantas (2011) encontraram que os alunos cujos pais têm ensino superior completo e aqueles cujos pais têm ensino fundamental incompleto obtiveram os maiores níveis de autoeficácia. De acordo com os autores, uma das explicações possíveis para os alunos com pais com menor escolaridade terem alta percepção de autoeficácia seria o fato desses estudantes terem avançado mais nos níveis de estudo do que seus pais e "essas experiências de êxito nas tarefas relativas ao aprender serviram de fonte de autoeficácia para esses estudantes" (GUERREIRO-CASANOVA, AZZI e DANTAS, 2011, p. 49).

Outro estudo desenvolvido por Leal et al. (2015) com alunos de Ensino Médio de duas escolas públicas localizadas no estado de São Paulo verificou uma relação positiva e significativa entre as crenças de autoeficácia acerca dos planos de carreira e o nível socioeconômico dos alunos. Nesses estudos, os autores encontraram que 
os alunos de nível socioeconômico mais alto também se sentiam mais confiantes em relação aos seus processos de transição da escola para o mercado de trabalho, isso envolvia planejar as suas carreiras, se preparar para a busca de emprego e empreender ações na busca de emprego.

Outro grupo de estudos sobre autoeficácia acadêmica busca associar o conceito ao desempenho dos alunos, como é o caso das pesquisas elaboradas por Oliveira e Soares (2011) e El Achkar et al. (2017). Ambos os estudos encontraram relações positivas e significativas entre o desempenho nas avaliações e a percepção de autoeficácia dos alunos. Dessa forma, encontraram que os alunos com baixo desempenho escolar apresentaram menores níveis de autoeficácia que os alunos de médio e alto desempenho. Além disso, o estudo de El Achkar et al. (2017) apontou que, dentre a amostra pesquisada, os alunos com baixo desempenho não pareciam se sentir capazes de realizar tarefas e atividades para conseguir alcançar as metas relacionadas ao alcance dos resultados desejados nas avaliações.

Os resultados dos estudos apresentados nesta seção mostram a importância das crenças de autoeficácia na trajetória e formação dos alunos, no entanto, o baixo número de artigos encontrados em um significativo período alerta para a necessidade de avançar nos estudos sobre autoeficácia no país.

\subsection{2. \\ Os estudos internacionais sobre autoeficácia e juventude}

Tendo em vista a amplitude do tema no cenário internacional, principalmente americano, optamos por fazer o levantamento de estudos internacionais a partir do recorte de cinco anos. Dessa forma, analisamos sete produções elaboradas em outros países que tratam sobre juventude e autoeficácia no período de 2015 a 2020 (BUTZ e USHER, 2015; MCCOY e BOWEN, 2017; VANTIEGUEM e HOUTE, 2015; HERRERA e MORENO, 2017; DOMÉNECHBETORET et al., 2017; BURGER e SAMUL, 2017; MANGANELLI et al., 2015). Assim como identificado nos estudos nacionais, as pesquisas internacionais privilegiam a metodologia quantitativa para análise dos dados e mensuram a autoeficácia dos jovens através da aplicação de questionários.

Uma das principais contribuições dos estudos internacionais para essa revisão é a centralidade dada às instituições escolares no desenvolvimento das crenças de autoeficácia escolar dos jovens. Os resultados dos estudos apontam que dentre as 
ações e condutas que estão no alcance do ambiente escolar e que são capazes de ampliar o nível de autoeficácia acadêmica estão o reconhecimento das conquistas dos alunos, o apoio dos professores quando os alunos possuem dificuldades, apoiar participação discente nas decisões em sala de aula (BUTZ; USHER, 2015) e nutrir as esperanças dos jovens em relação aos seus futuros (MCCOY; BOWEN, 2014).

Não obstante, é preciso salientar que apesar da escola ter importantes contribuições na construção das crenças de autoeficácia dos alunos, também há fatores individuais que influenciam como os alunos se sentem ao realizar as suas tarefas. O estudo de Vantieghem e Houtte (2015), como exemplo, apontou diferenças de percepção de autoeficácia em relação ao gênero, sendo as meninas as que possuíam maiores níveis de autoeficácia acadêmica. De acordo com os autores, isso poderia ser explicado pela pressão por conformidade de gênero presente na escola e na sociedade, já que os estereótipos do que seria "ser menina" se confundem, muitas vezes, com a visão de "bom aluno" que está presente na escola.

Por fim, os estudos trazem diversos resultados positivos associados a níveis elevados de autoeficácia: o maior desempenho nas avaliações (EL ACHKAR et al., 2017; HERRERA e MORENO, 2017; DOMÉNECH-BETORET et al., 2017), maior satisfação com a vida (BURGER e SAMUEL, 2017), maior satisfação com a escola (DOMÉNECH-BETORET et al., 2017) e maiores chances de engajamento cívico (MANGANELLI et al., 2015).

A revisão de literatura apresentada ao longo deste capítulo, sobre a influência do clima escolar, da participação discente e da autoeficácia na trajetória dos jovens estudantes, teve como um dos seus principais objetivos nortear a construção do questionário "Jovens e escolas: quais as relações?", instrumento de coleta de dados utilizado nesta pesquisa e que será apresentado no próximo capítulo 
4.

A construção do questionário "Jovens e escolas: quais as relações?"

Por muito tempo a pesquisa em educação ficou afastada dos métodos quantitativos de investigação, havendo, inclusive, um certo preconceito sobre aqueles que desenvolviam esse tipo de estudo dentro do campo educacional (GATTI, 2004; 2012; PEREIRA e ORTIGÃO, 2016). Uma das consequências desse distanciamento, de acordo com Gatti (2004), seria a falta de conhecimento de grande parte dos profissionais da educação no que se refere ao uso de dados demográficos e de medidas de um modo geral, que distanciava os pesquisadores do campo da educação dos estudos quantitativos.

Em contrapartida, nos últimos anos, a importância da utilização desse tipo de estudo no campo educacional vem sendo discutida por diferentes autores que reiteram a utilidade dos dados quantitativos para a elaboração de políticas públicas, para a aferição de determinadas tendências a partir de uma amostra significativa, para testar proposições complexas que envolvem diferentes variáveis em interação simultânea, entre outras utilidades (BABBIE, 1999; GATTI, 2004;2012; ORTIGÃO, 2009).

Dentro da abordagem quantitativa, o questionário é um dos instrumentos de coleta de dados mais utilizados pelos pesquisadores e a razão para esse fato se refere aos benefícios envolvidos na sua utilização. Em primeiro lugar, de acordo com Gil (2008, p. 128), o questionário pode ser definido "como a técnica de investigação composta por um número mais ou menos elevado de questões apresentadas por escrito às pessoas, tendo por objetivo o conhecimento de opiniões, crenças, sentimentos, interesses, expectativas, situações vivenciadas etc.”. No caso desta pesquisa, buscamos conhecer quais são as percepções, sentimentos e opiniões dos jovens sobre suas escolas, sobre suas trajetórias escolares e sobre eles mesmos. No que se refere aos benefícios da utilização dos questionários nas pesquisa, é possível elencar entre os principais pontos fortes a garantia do anonimato dos atores pesquisados, a possibilidade de aplicação do instrumento para uma grande quantidade de pessoas, ainda que estejam geograficamente distantes do pesquisador, a facilidade de conversão dos dados para o computador, a facilidade de criar sistemas determinísticos de causa e efeito entre as variáveis e a 
possibilidade do instrumento ser replicado por outros pesquisadores em outras amostras e subgrupos distintos (BABBIE, 1999; GIL, 2008; RIBEIRO, 2008).

Além dos benefícios citados acima, no caso deste estudo, outro aspecto que justifica a elaboração de um novo instrumento é o fato do grupo de pesquisa o qual a autora deste trabalho participa (GESQ - Gestão e Qualidade da Educação/PUCRio) já ter construído, testado e alcançado resultados significativos de pesquisa com outros questionários para diretores, coordenadores e professores (OLIVEIRA, 2015, entre outros), com estrutura semelhante ao desenvolvido para este trabalho. Futuramente, espera-se que os instrumentos possam ser utilizados de forma concomitante nas instituições de ensino para que possamos aprofundar as análises acerca dos processos que permeiam o ambiente escolar, a partir da visão dos diferentes atores escolares (alunos, professores e gestão). Por fim, o questionário possibilita reunir diferentes construtos que gostaríamos de investigar em um só instrumento, tais como: o clima escolar a partir da percepção dos estudantes, assim como seu ponto de vista sobre sua participação no ambiente escolar, sua crença na autoeficácia nesse contexto, assim como sobre a importância da escola e da aprendizagem escolar.

O principal argumento sobre a importância de incluir os alunos nas análises do espaço escolar está relacionado à centralidade de seu lugar nesse ambiente já que, do ponto de vista institucional, todas as ações empreendidas na escola estão voltadas para assegurar os processos de desenvolvimento social, psíquico e cognitivo dos estudantes. Como destaca Claro (2013), as comunidades escolares devem se organizar em virtude dos processos educativos dos alunos, já que esse é o objetivo principal da escola. Nossa escolha por aplicar o instrumento à alunos do $9^{\circ}$ ano do Ensino Fundamental se deu pelo fato de, embora a maior parte dos estudos sobre juventude focalizar os alunos do Ensino Médio, a situação das séries finais do Ensino Fundamental em termos de desempenho e evasão também são preocupantes e justificam a escolha desse segmento a fim de buscar novos elementos e lançar nova luz sobre o tema no âmbito da compreensão dos fatores intraescolares.

Nas próximas seções descreveremos todo o processo utilizado para a construção do questionário e para a validação teórica do instrumento. Este processo foi precedido, como mostraremos a seguir, de uma análise dos questionários já existentes que tratavam sobre jovens e escolas para identificar tendências e 
possíveis lacunas existentes nesses instrumentos e informar a construção de um novo questionário.

\section{1.}

Os questionários já existentes sobre juventude e escola

Após uma busca dentro do universo de pesquisas sobre jovens e escolas encontramos alguns instrumentos para serem analisados nessa primeira etapa da pesquisa: os questionários contextuais da Prova Brasil, do PISA (Programa de Internacional de Avaliação dos Estudantes) ${ }^{7}$ e do Proeb (Avaliação da Rede Pública de Educação Básica) ${ }^{8}$ de Minas Gerais, o questionário "Nossa Escola em (Re) construção" do Instituto Inspirare ${ }^{9}$, os questionários sobre clima escolar elaborados por Vinha et al. (2017) e por Bear et al (2011), as questões da pesquisa "Perfil da Juventude Brasileira" ${ }^{10}$ realizada pelo Instituto Cidadania de São Paulo com 34,1 milhões de jovens no ano de 2005 e, por fim, um questionário que foi aplicado na pesquisa de Pereira e Lopes (2016) sobre os motivos pelos quais os jovens vão à escola.

A revisão de todos esses instrumentos foi importante para compreender seus limites e potencialidades no que se refere à pesquisa com jovens. O levantamento feito indicou a falta de um instrumento mais completo sobre as diferentes questões que permeiam a trajetória dos alunos no espaço escolar. Alguns deles, englobam questões apenas sobre um tema específico, como o clima escolar (VINHA et al., 2017; BEAR et al., 2011), ou a mobilização dos alunos em relação à escola (PEREIRA e LOPES, 2016). Em outros, como o questionário contextual da Prova Brasil, os itens presentes no instrumento são limitados em termos de quantidade e estão voltados para a caracterização da condição socioeconômica do aluno, o nível de atuação dos pais no processo de escolarização, a frequência em atividades

\footnotetext{
${ }^{7}$ O PISA é uma avaliação internacional que mede o nível educacional de jovens de 15 anos por meio de provas de Leitura, Matemática e Ciências. Fonte: <https://www.gov.br/inep/pt-br/areas-deatuacao/avaliacao-e-exames-educacionais/pisa>. Acesso em: 01 de fevereiro de 2021.

${ }^{8}$ O Proeb é uma avaliação externa e censitária que busca diagnosticar a educação pública do estado de Minas Gerais nos $5^{\circ}$ e $9^{\circ}$ ano do Ensino Fundamental e $3^{\circ}$ ano do Ensino Médio por meio de provas de Português, Matemática, Ciências da Natureza e Ciências sociais. Fonte: <https://www2.educacao.mg.gov.br/aspectos-legais-e-responsabilidades/page/297-proeb>. Acesso em: 01 de fevereiro de 2021.

9 A pesquisa foi realizada pelo Porvir, projeto do Instituo Inspirare, em parceria com a Rede de Conhecimento Social e buscou conhecer o que os jovens pensam sobre a escola e qual educação almejam. Fonte: <https://porvir.org/sobre-nos/>. Acesso em: 01 de fevereiro de 2021.

${ }^{10}$ Os resultados da pesquisa assim como o questionário na integra estão disponíveis no livro "Retratos da juventude brasileira" de Helena Wendel Abramo e Pedro Paulo Martoni Branco (orgs.)
} 
extraescolares, situações de reprovação e abandono, a preferência de determinadas disciplinas escolares, a realização de deveres de casa e as projeções dos alunos para o futuro. No que se refere ao questionário "Nossa Escola em (Re)construção" um dos principais objetivos do instrumento é compreender a percepção dos jovens sobre a reforma do Ensino Médio promulgada no ano de 2016, não abrangendo outras questões de interesse para esta pesquisa.

Os questionários contextuais do PISA e do Proeb foram os mais completos encontrados. O questionário do Proeb, destinado aos alunos, é composto por 63 itens que são avaliados através de uma escala Likert $^{11}$ e buscam conhecer as opiniões, queixas e elogios dos estudantes em relação ao espaço em que eles estudam. Entre os itens, estão questões sobre os processos de ensino e aprendizagem que ocorrem na sala de aula, indisciplina, espaço físico da instituição, bullying, entre outros aspectos. Assim como no caso do Proeb, o questionário do PISA também possui itens que buscam medir os diferentes aspectos da vida dos jovens no espaço escolar e é o instrumento mais longo analisado neste estudo. $\mathrm{O}$ questionário conta com itens sobre hábitos de leitura dos alunos, tempo dedicado aos estudos, interesse por questões globais e ambientais, práticas dos professores em sala de aula, crenças de autoeficácia dos alunos, letramento financeiro, bemestar na escola e em casa e trajetória escolar vivida. No entanto, em ambos os questionários sentimos falta de questões que tratassem da mobilização em relação à escola e a aprendizagem, ou seja, o que motiva os alunos a ir à escola e a aprender. No caso do questionário do Proeb, não há questões sobre participação discente e autoeficácia, dois temas trazidos pela literatura pesquisada como sendo de interesse para este trabalho. Por fim, o questionário do PISA contêm diversas questões sobre assuntos que não interessam para a nossa pesquisa, como o interesse dos alunos por questões globais e sobre letramento financeiro.

Decidimos então construir um novo questionário capaz de apreender através de um único instrumento os principais aspectos que permeiam a relação dos jovens com a escola que também possibilitasse analisar de forma mais ampla e profunda os fatores atinentes às instituições de ensino, a partir da visão de diferentes atores que convivem no contexto escolar. Além disso, como aponta Oliveira (2015, p. 73),

\footnotetext{
${ }^{11}$ A escala Likert é um tipo de escala unidimensional utilizada por pesquisadores para medir posturas e opiniões com um nível maior de nuance se comparadas a perguntas binárias, de "sim" ou "não". Fonte: https://pt.surveymonkey.com/mp/likert-scale/. Acesso em: 01 de fevereiro de 2021.
} 
Um dos desafios impostos para o desenvolvimento de pesquisas quantitativas se configura no levantamento e/ou acesso às informações desejadas, seja através da elaboração e aplicação de surveys específicos, seja através do acesso às bases de dados já disponíveis.

Através da construção deste questionário buscamos contribuir com o avanço das pesquisas quantitativas dentro da área da educação e, principalmente, daquelas que analisam a relação dos jovens com a escola.

Nos próximos tópicos, detalhamos o processo de construção do instrumento, desde a identificação dos conceitos na literatura que estarão presentes no questionário até a aplicação do mesmo a uma amostra de 224 jovens de escolas públicas e particulares nas cidades do Rio de Janeiro (RJ) e São Luís (MA).

\section{2. \\ Procedimentos metodológicos para a construção de um novo questionário}

Para a construção do questionário foi utilizado como referência o processo descrito por Oliveira (2015, p. 93):

1) Definição dos conceitos primários e conceitos secundários (o que queremos medir?); 2) Identificação de como estes conceitos se manifestam no contexto observado (latentes ou observáveis); 3) Especificação dos itens (como medir?); 4) Operacionalização dos itens em variáveis (o que conseguimos medir?).

Este capítulo 4 descreve as três primeiras etapas do processo e a quarta etapa será detalhada no capítulo 5 desta dissertação. O resultado do questionário construído encontra-se no apêndice A deste trabalho.

\subsection{1.}

\section{Identificação dos conceitos primários e secundários e sua operacionalização}

Diversos autores chamam atenção para a centralidade da revisão teórica e empírica na construção do instrumento de pesquisa. De acordo com Pereira e Ortigão (2016, p. 73):

Estruturar um quadro referencial é importante para, em primeiro lugar, elaborar questões pertinentes que sejam coerentes, façam sentido dentro do escopo de pesquisa e, apetecivelmente, permitam desdobramentos em modelos de referência cruzada, por exemplo. Um equívoco comum é investir esforços em aplicar questionários ou entrevistas sem uma base teórica 
construída. Essa situação não é desejável, pois pode desperdiçar tempo e trabalho, produzindo respostas superficiais e pouco úteis ao trabalho.

No caso dessa pesquisa, dentro do escopo de temas e questões que permeiam as relações entre os jovens e as escolas, já apresentados nos capítulos precedentes, decidimos elencar quatro conceitos principais para o questionário: a mobilização dos jovens em relação à escola e a aprendizagem, o clima escolar, a participação discente e as crenças de autoeficácia. A principal justificativa desta escolha foi a revisão de literatura que apontou que esses fatores têm uma grande influência na forma como os jovens se relacionam com a escola. Além disso, como já assinalado, o grupo de pesquisa Gestão e Qualidade na Educação (GESQ) já possui instrumentos de pesquisas que buscam avaliar a percepção sobre a escola de professores, diretores e membros das equipes de gestão. Esses instrumentos, por sua vez, contêm itens sobre clima escolar, participação e autoeficácia, dessa forma, achamos interessante compor também o questionário do aluno com itens semelhantes para possibilitar, futuramente, comparar a percepção dos diferentes atores escolares sobre as mesmas questões.

A elaboração dos itens que mediriam cada um dos quatro conceitos centrais, foi lastreada na revisão bibliográfica e empírica apresentada nos capítulos 2 e 3 deste trabalho. Após a aferição dos conceitos centrais, ou primários, foi necessário identificar dentro deles dimensões ou manifestações (conceitos secundários) que dessem conta de componentes específicos de cada um dos conceitos primários e possibilitassem sua medida, mesmo que indireta. Por exemplo, dentro do conceito de participação (conceito primário), pode-se desejar saber o nível de participação dentro do espaço escolar (seja em âmbito geral, seja no da sala de aula) ou o nível de participação dos alunos em atividades extraescolares, como ONG's ou movimentos sociais (conceitos secundários).

O Quadro 1 apresentado a seguir traz os conceitos primários e secundários da presente pesquisa e a identificação de como estes conceitos se manifestam no contexto observado, ou seja, se são observáveis ou latentes. Um conceito latente é aquele que não é possível observar diretamente e, por isso, demanda que o pesquisador busque uma aproximação do que se quer observar, via de regra através de modelos matemáticos ou estatísticos, como a análise fatorial, por exemplo, pois sua inferência depende da associação de diferentes manifestações observáveis e/ou de percepções a respeito de diferentes dimensões do mesmo fenômeno captadas de 
forma específica por diversos itens. Por outro lado, um conceito observável, como o próprio nome denuncia, é aquele que é possível observar diretamente (BABBIE, 1999).

Quadro 1 - Temas, conceitos e suas classificações

\begin{tabular}{|c|c|c|}
\hline Conceitos Primários & Conceitos Secundários & Classificação \\
\hline \multirow{2}{*}{$\begin{array}{l}\text { Relação com a escola e } \\
\text { com o saber }\end{array}$} & Mobilização em relação à escola & Latente \\
\hline & Relação com o saber & Latente \\
\hline \multirow{6}{*}{ Clima Escolar } & Ensino Aprendizagem & Latente \\
\hline & Pertencimento & Latente \\
\hline & Relações interpessoais & Latente \\
\hline & Normas, Regras e Sanções & Latente \\
\hline & Bullying e Discriminação & Latente \\
\hline & Ambiente físico & Observável \\
\hline \multirow{3}{*}{ Participação } & Espaços de participação & Latente \\
\hline & Compartilhamento das decisões & Latente \\
\hline & Incentivo à participação extraescolar & Latente \\
\hline \multirow{4}{*}{ Autoeficácia } & Capacidade de continuar os estudos & Latente \\
\hline & $\begin{array}{l}\text { Capacidade de cooperar com os } \\
\text { colegas, professores e com a escola }\end{array}$ & Latente \\
\hline & $\begin{array}{l}\text { Capacidade de conseguir um bom } \\
\text { emprego futuramente }\end{array}$ & Latente \\
\hline & Capacidade de obter bons resultados & Latente \\
\hline \multirow{4}{*}{ Hábitos juvenis } & Lazer & Latente \\
\hline & Trabalho & Latente \\
\hline & Participação Social & Latente \\
\hline & Tarefas domésticas & Latente \\
\hline \multirow{4}{*}{ Trajetória escolar } & Início da escolarização & Observável \\
\hline & Percepções sobre o futuro & Latente \\
\hline & Reprovação & Observável \\
\hline & Tipo de instituição & Observável \\
\hline \multirow{5}{*}{ Perfil socioeconômico } & Idade & Observável \\
\hline & Cor/raça & Observável \\
\hline & Sexo & Observável \\
\hline & Bens materiais & Observável \\
\hline & Escolaridade dos pais & Observável \\
\hline
\end{tabular}

Como pôde ser observado no Quadro 1, além dos quatro conceitos primários que foram discutidos ao longo dos capítulos 2 e 3, o questionário também contará com questões sobre os hábitos juvenis, a trajetória escolar e o perfil socioeconômico dos alunos. Este último nos permitirá entender as relações entre a condição socioeconômica dos indivíduos e as demais variáveis. 


\subsection{2 \\ Especificação dos itens que irão compor o questionário.}

Nesta seção, apresentaremos os itens que foram selecionados e criados para medir os construtos latentes que farão parte do nosso instrumento. Como já mencionado, um construto latente não pode ser medido diretamente através de uma simples observação, por isso é necessário operacionalizar esses conceitos através das suas manifestações (CAZELLI, 2005). Exemplos de variáveis latentes poderiam ser a ansiedade, a inteligência, o medo, a autoeficácia, entre outros sentimentos. Andy Field (2011), para exemplificar o que seriam conceitos latentes traz a ideia de exaustão. Segundo o autor, a exaustão possui diversas facetas e não seria possível medi-la através de uma simples pergunta, como "você está exausto?". Por esse motivo, devemos medir os vários aspectos da exaustão, como a motivação, o nível de estresse, se a pessoa tem alguma nova ideia para determinado trabalho, entre outros aspectos para compreender como essa pessoa está se sentindo.

A seguir, apresentamos os conceitos latentes e observáveis presentes em nosso instrumento, como eles se manifestam e a tradução dessas manifestações em itens do questionário.

- Relação com a escola e com a aprendizagem:

A primeira seção do capítulo 3 deste trabalho apontou que uma das principais questões referentes à relação da juventude brasileira com a escola perpassa o debate da importância da escola e do que se aprende nesse espaço. Os estudos analisados apontaram que os jovens conferem diferentes significados ao fato de ir à escola e ao aprender e definem estas relações através de duas perspectivas: a mobilização em relação à escola (relativa ao fato de ir para a escola) e a mobilização na escola (relação com o saber) que podem ocorrer de diferentes maneiras (CHARLOT, 1996; 2002; FREITAS; BATISTA E MELLO, 2016; PEREIRA; LOPES, 2016; BRENNER; CARRANO, 2014; DAYRELL; JESUS, 2016).

Em relação à mobilização em relação à escola, ou seja, que sentidos os jovens atribuem ao fato de ir à escola, alguns itens do questionário elaborado por Pereira e Lopes (2016) na pesquisa intitulada "Por que ir à escola? Os sentidos atribuídos pelos jovens do Ensino Médio" foram adaptados e utilizados em nosso instrumento. $\mathrm{Na}$ fase operacionalização dos itens, que será apresentada no capítulo 5, pretendemos construir alguns índices que serão responsáveis por mensurar o tipo de mobilização do aluno em relação à escola, ou seja, se a motivação dos alunos 
para irem à escola estaria mais vinculada à aprendizagem, ao futuro ou à socialização.

No que se refere aos itens que buscam compreender os sentidos dados pelos jovens em relação ao que eles aprendem na escola, eles foram elaborados pela própria autora desta pesquisa e sua construção não possibilita a operacionalização em escalas ou índices, como a questão anterior. A tabela a seguir apresenta os itens que compuseram o conceito primário latente "Relação com a escola e com a aprendizagem”.

Quadro 2 - Relação com a escola e com a aprendizagem: especificação dos itens

\begin{tabular}{|c|c|c|}
\hline Conceitos Secundários & Especificação & Item \\
\hline $\begin{array}{l}\text { Mobilização em relação } \\
\text { à escola }\end{array}$ & $\begin{array}{l}\text { - Pense nos motivos pelos quais você vai à } \\
\text { escola. Marque qual é o seu nível de } \\
\text { concordância com as afirmativas abaixo: } \\
\text { a) Vou à escola porque sou obrigado } \\
\text { b) Vou à escola porque é meu direito } \\
\text { c) Vou à escola porque gosto de aprender } \\
\text { d) Vou à escola porque me interesso por } \\
\text { alguma disciplina } \\
\text { e) Vou à escola porque gosto dos } \\
\text { professores } \\
\text { f) Vou à escola porque acho importante } \\
\text { para conseguir emprego futuramente } \\
\text { g) Vou à escola para tentar entrar na } \\
\text { faculdade/ensino superior } \\
\text { h) Vou à escola para escola para ter } \\
\text { melhores condiçôes de vida do que meus } \\
\text { pais } \\
\text { i) Vou à escola para encontrar com os } \\
\text { amigos } \\
\text { j) Vou à escola porque gosto do } \\
\text { intervalo/recreio. }\end{array}$ & I1 \\
\hline Relação com o saber & $\begin{array}{l}\text { - Na sua opinião, qual o grau de importância } \\
\text { do que você aprende na escola nos seguintes } \\
\text { aspectos da sua vida: } \\
\text { a) Para o meu futuro profissional. } \\
\text { b) Para compreender a realidade do mundo. } \\
\text { c) Para as coisas que faço no dia a dia. } \\
\text { d) Para fazer amigos. } \\
\text { e) Para acessar os conhecimentos e saberes } \\
\text { f) Produzidos pela ciência. }\end{array}$ & $\mathrm{I} 2$ \\
\hline
\end{tabular}




\section{- Clima escolar}

Considerando a multiplicidade de definições e dimensões que compõem o clima escolar, como apontado na revisão de literatura no capítulo 3, o presente estudo optou por compreender o clima escolar como um resultado das características individuais de cada instituição e da percepção dos atores acerca dessas características. Sendo assim, o clima da escola tende a ser positivo quando os sujeitos que fazem parte da instituição estão de acordo com as práticas daquele ambiente e compartilham os valores e normas presentes na instituição, o que tende a favorecer um ambiente propício também para a aprendizagem. As dimensões analisadas neste estudo, considerando a perspectiva do aluno, serão: ambiente físico (qualidade do espaço físico e infraestrutura da escola); ensino aprendizagem (percepção da escola como um lugar propício para a aprendizagem, em que os professores motivam os alunos, se interessam e acompanham os seus processos de aprendizagem); segurança (existência de conflitos e situações de violência dentro do espaço escolar); conexão com a escola (sentimento de pertencimento em relação à instituição e como o aluno se sente dentro do ambiente escolar), normas, regras e sanções (existência de regras e sanções claras e justas para todos os alunos) e relações interpessoais (qualidade das interações entre os atores escolares).

No que se refere aos itens que irão medir o construto "clima escolar", alguns deles foram construídos pela própria autora e outros foram inspirados em questionários já existentes (VINHA et al., 2017; Proeb, 2011; OLIVEIRA, 2015). A construção dos itens presentes nessa seção foi pensada para possibilitar a criação de diferentes índices de acordo com as dimensões do clima escolar elencadas, sendo assim, na fase de operacionalização dos itens serão construídos índices que serão responsáveis por medir o clima das instituições pesquisadas. A seguir, o Quadro 3 apresenta os itens com os quais se busca medir o conceito latente "Clima escolar" no instrumento desenvolvido.

Quadro 3 - Clima escolar: especificação dos conceitos secundários

\begin{tabular}{|c|c|c|}
\hline Conceitos Secundários & Especificação & Item \\
\hline Ensino e aprendizagem & $\begin{array}{l}\text { - Considerando a maioria das suas aulas, } \\
\text { indique a frequência com que estas coisas } \\
\text { acontecem na sua escola: } \\
\text { a) Os alunos não escutam o que os } \\
\text { professores dizem/ Há desordem e } \\
\text { confusão em sala de aula. }\end{array}$ & I5 \\
\hline
\end{tabular}




\begin{tabular}{|c|c|c|}
\hline Conceitos Secundários & Especificação & Item \\
\hline & $\begin{array}{l}\text { b) Os professores precisam esperar um } \\
\text { longo tempo para os alunos ficarem } \\
\text { em silêncio. } \\
\text { c) Os professores demonstram interesse } \\
\text { na aprendizagem de todos os alunos. } \\
\text { d) Os professores mandam deveres de } \\
\text { casa. } \\
\text { e) Os professores corrigem os deveres } \\
\text { de casa. } \\
\text { f) Os professores fazem perguntas para } \\
\text { saber se os alunos entenderam o que } \\
\text { foi ensinado. } \\
\text { g) Os professores me falam como posso } \\
\text { melhorar meu desempenho escolar. } \\
\text { h) Os professores encorajam os alunos a } \\
\text { expressarem a sua opinião sobre os } \\
\text { temas estudados. } \\
\text { i) Os professores apoiam e incentivam } \\
\text { os alunos a participarem ativamente. }\end{array}$ & \\
\hline Pertencimento & $\begin{array}{l}\text { - Pense na escola em que você estuda. } \\
\text { Marque qual é o seu nível de concordância } \\
\text { com cada uma das afirmativas abaixo: } \\
\text { a) Gosto de estudar na minha escola. } \\
\text { b) Na minha escola, sinto que todos } \\
\text { estão atentos às minhas necessidades. } \\
\text { c) Na minha escola, sinto que sou } \\
\text { valorizado por todos. } \\
\text { d) Tenho orgulho de ser aluno da minha } \\
\text { escola. }\end{array}$ & $\begin{array}{c}\mathrm{I} 3 \\
(3.1 \\
3.9 ; 3 \\
10 ; 3.1 \\
1)\end{array}$ \\
\hline Relações interpessoais & $\begin{array}{l}\text { - Marque a opção que melhor expressa como } \\
\text { você avalia a sua relação com: } \\
\text { a) Os professores. } \\
\text { b) O(a) diretor(a). } \\
\text { c) A coordenação. } \\
\text { d) Os funcionários da escola. } \\
\text { e) Os colegas de turma. } \\
\text { f) Os outros alunos da escola. }\end{array}$ & $\mathrm{I} 4$ \\
\hline $\begin{array}{l}\text { Normas, regras e } \\
\text { sanções }\end{array}$ & $\begin{array}{l}\text { - Pense na escola em que você estuda. } \\
\text { Marque qual é o seu nível de concordância } \\
\text { com cada uma das afirmativas abaixo: } \\
\text { a) Na minha escola, as regras são claras } \\
\text { para todos os alunos; } \\
\text { b) Na minha escola as regras são justas; }\end{array}$ & $\begin{array}{c}\mathrm{I} 3 \\
(3.12 ; \\
3.13 ; 3 \\
.14)\end{array}$ \\
\hline
\end{tabular}




\begin{tabular}{|l|r|c|}
\hline Conceitos Secundários & Especificação & Item \\
\hline \multirow{5}{*}{ Ambiente físico } & $\begin{array}{l}\text { c) Na minha escola, as consequências } \\
\text { para aqueles que quebram as regras } \\
\text { são justas. }\end{array}$ & \\
\hline & $\begin{array}{l}\text { Marque qual é o seu nível de concordância } \\
\text { com cada uma das afirmativas abaixo: }\end{array}$ & I3 \\
& $\begin{array}{l}\text { a) A minha escola oferece um ambiente } \\
\text { favorável para todos aprenderem; }\end{array}$ & (3.1;3. \\
& $\begin{array}{l}\text { b) minha escola, as salas de aula são } \\
\text { confortáveis, limpas e conservadas; }\end{array}$ & $2 ; 3.3)$ \\
& c) Na minha escola há uma biblioteca \\
com livros variados. & \\
\hline
\end{tabular}

Elaboração própria

\section{- Participação}

Para elaborar os itens sobre o construto participação, utilizamos os principais referenciais teóricos e resultados das pesquisas empíricas que foram discutidas no capítulo 3 desta dissertação (THOMPSON, 2011; MARTINS e DAYRELL, 2015, MITRA; GROSS, 2009; MITRA, 2005, KANE e CHIMWAYANGE, 2014). Tendo em vista que as pesquisas apontaram que a participação dos alunos pode ocorrer não apenas em espaços destinados exclusivamente para isso, como o caso do grêmio estudantil, mas também no cotidiano da escola, dentro da sala de aula, com os alunos opinando e debatendo sobre as práticas inerentes a esse espaço, decidimos por medir a participação dos alunos nessas distintas ocasiões. Além disso, considerando que algumas pesquisas (DAYRELL, GOMES e LEÃO, 2010) também apontaram a importância de incentivar os alunos a participarem de ações dentro da sociedade e fora do espaço escolar, com o intuito de promover situações para o exercício e aprendizagem da vida coletiva, incorporamos itens que procuram medir o incentivo da escola para a participação dos alunos em atividades extraescolares. No Quadro que se segue são apresentados os itens que medirão a participação dos alunos dentro e fora do ambiente escolar. 
Quadro 4 - Participação: especificação dos conceitos secundários

\begin{tabular}{|c|c|c|}
\hline Conceitos Secundários & Especificação & Item \\
\hline Espaços de participação & $\begin{array}{l}\text { - A sua escola possui grêmio estudantil ou } \\
\text { outra forma de representação estudantil? } \\
\text { Não/ Sim. }\end{array}$ & I6 \\
\hline & $\begin{array}{l}\text { - Você acha que os alunos devem participar } \\
\text { das decisões da escola que dizem respeito } \\
\text { aos estudantes? Não / Sim. }\end{array}$ & I7 \\
\hline & $\begin{array}{l}\text { - Em relação à sua participação nas } \\
\text { decisões da escola que dizem respeito os } \\
\text { alunos, você: } \\
\text { a) Acho que participo o suficiente. } \\
\text { b) Participo, mas gostaria de participar } \\
\text { mais. } \\
\text { c) Não participo, mas gostaria de } \\
\text { participar. }\end{array}$ & $\begin{array}{l}\text { I8 }(8.1 ; \\
8.2 ; 8.3 ; \\
8.4)\end{array}$ \\
\hline $\begin{array}{l}\text { Compartilhamento das } \\
\text { decisões }\end{array}$ & $\begin{array}{l}\text { - Indique a frequência com que estas coisas } \\
\text { acontecem na sua escola: } \\
\text { a) Os alunos são convidados a darem } \\
\text { suas opiniões sobre o que é melhor } \\
\text { para a turma ou para a escola. } \\
\text { b) Os alunos sentem que suas opiniões } \\
\text { são ouvidas pelos professores, } \\
\text { coordenadores e diretor (a). } \\
\text { c) Os alunos sentem que suas opiniões } \\
\text { são consideradas pelos professores, } \\
\text { coordenadores e diretor. } \\
\text { d) Os alunos participam das mudanças } \\
\text { das regras da escola. }\end{array}$ & I8 (8.5) \\
\hline $\begin{array}{l}\text { Participação } \\
\text { extraescolar }\end{array}$ & $\begin{array}{l}\text { - Indique a frequência com que estas coisas } \\
\text { acontecem na sua escola: } \\
\text { a) Os alunos são incentivados a } \\
\text { participarem de ações fora da escola } \\
\text { (projetos sociais, trabalhos em } \\
\text { ONGS, movimentos sociais). }\end{array}$ & \\
\hline
\end{tabular}

Elaboração própria.

- Autoeficácia

Para este trabalho utilizaremos a definição de autoeficácia defendida por Bandura (1993). Para o autor, o termo pode ser compreendido como um julgamento pessoal das próprias capacidades de exercer controle sobre o seu desempenho em determinadas situações e eventos que afetam a sua vida. Segundo o autor, essa 
crença influencia a forma como as pessoas se sentem, pensam, se motivam e se comportam (BANDURA, 1996, p. 118). Nesta pesquisa, buscaremos avaliar a crença de autoeficácia dos alunos em relação a sua capacidade de continuar os estudos, ter bons resultados na escola, conseguir um bom trabalho futuramente, cooperar com os colegas, com os professores e com a escola. A seguir, o Quadro 5 apresenta os itens que serão responsáveis por medir o construto da autoeficácia.

Quadro 5 - Autoeficácia: especificação dos conceitos secundários

\begin{tabular}{|c|c|c|}
\hline Conceitos Secundários & Especificação dos itens & Item \\
\hline $\begin{array}{l}\text { Capacidade de } \\
\text { continuar os estudos }\end{array}$ & $\begin{array}{l}\text { - Indique em que medida você se sente } \\
\text { capaz de: } \\
\text { a) Concluir o Ensino Médio. } \\
\text { b) Ingressar no ensino superior; }\end{array}$ & I9 $(9.1 ; 9.2)$ \\
\hline $\begin{array}{l}\text { Capacidade em relação } \\
\text { ao desempenho escolar }\end{array}$ & $\begin{array}{l}\text { - Indique em que medida você se sente } \\
\text { capaz de: } \\
\text { a) Obter bons resultados nas } \\
\text { avaliações. }\end{array}$ & I9 (9.3) \\
\hline $\begin{array}{l}\text { Capacidade de } \\
\text { contribuir com a escola } \\
\text { e com os colegas. }\end{array}$ & $\begin{array}{l}\text { - Indique em que medida você se sente } \\
\text { capaz de: } \\
\text { a) Ajudar meus colegas quando } \\
\text { estão com dificuldade em } \\
\text { algum conteúdo. } \\
\text { b) Contribui com a harmonia em } \\
\text { sala de aula. } \\
\text { c) Pensar em soluções para } \\
\text { problemas que estejam } \\
\text { acontecendo na escola. }\end{array}$ & $\begin{array}{c}\mathrm{I} 9 \\
(9.5 ; 9.6 ; 9.7)\end{array}$ \\
\hline $\begin{array}{l}\text { Capacidade de } \\
\text { conseguir bom emprego } \\
\text { futuramente }\end{array}$ & $\begin{array}{l}\text { - Indique em que medida você se sente } \\
\text { capaz de: } \\
\text { a) Conseguir um bom emprego } \\
\text { futuramente. }\end{array}$ & I9 (9.4) \\
\hline
\end{tabular}

Elaboração própria.

\section{- Hábitos juvenis}

Com este construto buscaremos compreender o que os jovens fazem no seu tempo livre fora da escola. De acordo com Brenner, Dayrell e Carrano (2005), entender como os jovens ocupam os seus tempos livres é importante para compreender os sentidos atuais do próprio tempo da juventude na sociedade. Considerando que os jovens participantes da nossa pesquisa pertencem a distintos grupos sociais e tipos de escolas (públicas e privadas), buscaremos apreender como 
utilizam o seu tempo e quais as diferenças e similitudes na forma de viver a juventude entre esses sujeitos que compartilham da mesma geração, mas que integram grupos sociais distintos. Alguns dos itens que compõem esse construto foram retirados de outros questionários já existentes, como é o caso das questões sobre lazer e trabalhos domésticos (oriundas dos questionários contextuais da Prova Brasil) e de hábitos de leitura (presentes nos questionários contextuais do PISA). O quadro que se segue apresenta a especificação dos conceitos latentes que compõem o construto hábitos juvenis.

Quadro 6 - Hábitos juvenis: especificação dos conceitos secundários

\begin{tabular}{|c|c|c|}
\hline Conceito & Especificação & Item \\
\hline $\begin{array}{l}\text { Participação } \\
\text { social }\end{array}$ & $\begin{array}{l}\text { - Você participa de: (marque todas as alternativas que } \\
\text { se aplicam ou nenhuma alternativa): } \\
\text { a) Organização social não governamental (ex. } \\
\text { ONGs). } \\
\text { b) Coletivo (feminista, LGBTQ, negro ou outro). } \\
\text { c) Movimento estudantil. } \\
\text { d) Partido político. }\end{array}$ & $\mathrm{I} 10$ \\
\hline \multirow[t]{2}{*}{ Lazer } & $\begin{array}{l}\text { - Indique a frequência com que você costuma ir à/ao: } \\
\text { a) Biblioteca. } \\
\text { b) Cinema. } \\
\text { c) Festas na vizinhança. } \\
\text { d) Baile Funk. } \\
\text { e) Show musical. } \\
\text { f) Casa de amigos. } \\
\text { g) Lanchonete ou Restaurante. } \\
\text { h) Praia. } \\
\text { i) Shopping. } \\
\text { j) Teatro. } \\
\text { k) Museu. } \\
\text { l) Parques. } \\
\text { m) Locais religiosos. }\end{array}$ & I11 \\
\hline & $\begin{array}{l}\text { - Em dias de aula, quanto tempo você gasta vendo } T V \text {, } \\
\text { navegando na internet ou jogando jogos eletrônicos? } \\
\text { a) Menos de uma hora. } \\
\text { b) Entre } 1 \text { e } 2 \text { horas. } \\
\text { c) Mais de } 2 \text {, até } 3 \text { horas. } \\
\text { d) Mais de } 3 \text { horas. } \\
\text { e) Não vejo TV, não navego na internet e não } \\
\text { jogo jogos eletrônicas. }\end{array}$ & $\mathrm{I} 12$ \\
\hline
\end{tabular}




\begin{tabular}{|l|l|c|}
\hline \multicolumn{1}{|c|}{ Conceito } & \multicolumn{1}{|c|}{ Especificação } & Item \\
\hline Trabalhos & $\begin{array}{l}\text { - Em dias de aula, quanto tempo você gasta fazendo } \\
\text { domésticos }\end{array}$ & \\
& $\begin{array}{r}\text { trabalhos domésticos? } \\
\text { a) Menos de uma hora. }\end{array}$ & \\
& b) Entre 1 e 2 horas. & \\
& c) Mais de 2, até três horas. & \\
& d) Mais de 3 horas. & \\
leitura & e) Não faço trabalhos domésticos. & \\
& anitos Notícias sobre política. & \\
& b) Notícias sobre celebridades. & \\
& c) Notícias sobre cultura (arte, música, viagens). & \\
& de Notícias sobre esportes. & \\
\hline
\end{tabular}

Elaboração própria.

- Caracterização sociodemográfica

O último tópico do questionário será responsável por identificar o perfil dos jovens pesquisados em relação as suas características sociais e econômicas: idade, sexo, escolarização dos pais, trajetória de escolarização e bens materiais. Inúmeros estudos na área de Sociologia da Educação, desde a década de 60, apontaram a influência das características sociais e econômicas dos alunos nas suas trajetórias escolares, o que torna incontornável considerar esse aspecto na presente pesquisa. Grande parte dos itens que compõem esse construto foram retirados do questionário contextual do aluno da Prova Brasil. Essa atitude se justifica pelo fato de o questionário já ter a sua significância e confiabilidade testada, tendo em vista a sua aplicação em larga escala há vários anos.

Quadro 7 - Caracterização sociodemográfica: especificação dos conceitos secundários

\begin{tabular}{|l|l|c|}
\hline Conceitos Secundários & Especificação dos itens & Item \\
\hline Trabalho & $\begin{array}{l}\text { - Atualmente você trabalha fora de casa } \\
\text { (recebendo ou não salário)? Não/ Sim }\end{array}$ & I15 \\
\hline \multirow{5}{*}{$\begin{array}{l}\text { Trajetória } \\
\text { vivida }\end{array}$} & $\begin{array}{l}\text { - Quando você começou a ir à escola? } \\
\text { a) Na creche (0 a 3 anos); } \\
\text { b) Na pré-escola (4 e 5 anos); } \\
\text { c) Na primeira série ou primeiro ano (6 } \\
\text { a 7 anos); }\end{array}$ & I18 \\
& $\begin{array}{l}\text { d) Depois da primeira série ou } \\
\text { primeiro ano. }\end{array}$ & \\
\cline { 2 - 4 } & $\begin{array}{l}- \text { A partir do sexto ano, em que tipo de } \\
\text { escola você estudou? }\end{array}$ & I19 \\
\hline
\end{tabular}




\begin{tabular}{|c|c|c|}
\hline Conceitos Secundários & Especificação dos itens & Item \\
\hline & $\begin{array}{l}\text { a) Somente escola pública municipal. } \\
\text { b) Somente escola pública federal. } \\
\text { c) Somente escola pública estadual. } \\
\text { d) Somente escola particular. } \\
\text { e) Em escola pública e particular. }\end{array}$ & \\
\hline & - Você já foi reprovada? Não/ Sim & $\mathrm{I} 20$ \\
\hline & $\begin{array}{l}\text { - Você já ficou sem estudar por um tempo e } \\
\text { depois voltou a se matricular? Não/ Sim }\end{array}$ & $\mathrm{I} 21$ \\
\hline \multirow[t]{2}{*}{$\begin{array}{l}\text { Trajetória escolar } \\
\text { pretendida }\end{array}$} & $\begin{array}{l}\text { - Quando você terminar o } 9^{\circ} \text { ano, o que } \\
\text { você pretende fazer? } \\
\text { a) Somente continuar estudando. } \\
\text { b) Somente trabalhar. } \\
\text { c) Continuar estudando e trabalhar. } \\
\text { d) Ainda não sei }\end{array}$ & $\mathrm{I} 16$ \\
\hline & $\begin{array}{l}\text { - Daqui a } 5 \text { anos, você se imagina cursando } \\
\text { o Ensino Superior? Não/ Sim. }\end{array}$ & $\mathrm{I} 17$ \\
\hline Sexo & - Qual é o seu sexo? Feminino/ Masculino & $\mathrm{I} 22$ \\
\hline Idade & - Informe o mês e ano do seu nascimento & $\mathrm{I} 23$ \\
\hline Cor/Raça & $\begin{array}{l}\text { - Qual é a sua cor ou raça? } \\
\text { a) Branca. } \\
\text { b) Preta. } \\
\text { c) Parda. } \\
\text { d) Amarela. } \\
\text { e) Indígena. } \\
\text { f) Prefiro não declarar. }\end{array}$ & $\mathrm{I} 24$ \\
\hline \multirow[t]{2}{*}{ Bens materiais } & $\begin{array}{l}\text { - Marque os itens que você possui na sua } \\
\text { casa: } \\
\text { a) Uma mesa para estudar } \\
\text { b) Um quarto só para você. } \\
\text { c) Um lugar silencioso para estudar. } \\
\text { d) Um computador que você possa } \\
\text { usar para fazer trabalhos da escola. } \\
\text { e) Internet. } \\
\text { f) Livros de literatura clássica. } \\
\text { g) Livros de poesia. } \\
\text { h) Trabalhos artísticos (ex.: quadros, } \\
\text { esculturas). } \\
\text { i) Televisão. } \\
\text { j) Máquina de roupa/ Carro }\end{array}$ & $\mathrm{I} 25$ \\
\hline & $\begin{array}{l}\text { - Quantos livros você tem na sua casa? } \\
\text { a) 0-10 livros; }\end{array}$ & $\mathrm{I} 26$ \\
\hline
\end{tabular}




\begin{tabular}{|c|c|c|}
\hline Conceitos Secundários & Especificação dos itens & Item \\
\hline & $\begin{array}{l}\text { b) 11-25 livros; } \\
\text { c) 26-100 livros; } \\
\text { d) 101-200 livros; } \\
\text { e) 201-500 livros; } \\
\text { f) Mais de } 500 \text { livros }\end{array}$ & \\
\hline \multirow[t]{2}{*}{$\begin{array}{l}\text { Nível de escolaridade } \\
\text { dos pais }\end{array}$} & $\begin{array}{l}\text { - Até que série o seu pai, ou homem } \\
\text { responsável por você estudou? } \\
\text { a) Nunca estudou. } \\
\text { b) Não completou a } 4^{\mathrm{a}} \text { série/ } 5^{\circ} \text { ano do } \\
\text { Ensino Fundamental. } \\
\text { c) Completou a } 8^{\mathrm{a}} \text { série } / 9^{\circ} \text { ano do } \\
\text { Ensino Fundamental. } \\
\text { d) Completou o Ensino Médio, mas } \\
\text { não completou a Faculdade. } \\
\text { e) Completou a faculdade. } \\
\text { f) Não sei. }\end{array}$ & \\
\hline & $\begin{array}{l}\text { - Até que série a sua mãe, ou mulher } \\
\text { responsável por você estudou? } \\
\text { a) Nunca estudou. } \\
\text { b) Não completou a } 4^{\text {a }} \text { série. } \\
\text { c) } 5^{\circ} \text { ano do Ensino Fundamental. } \\
\text { d) Completou a } 8^{\text {a }} \text { série. } \\
\text { e) } 9^{\circ} \text { ano do Ensino Fundamental. } \\
\text { f) Completou o Ensino Médio, mas } \\
\text { não completou a Faculdade. } \\
\text { g) Completou a faculdade. } \\
\text { h) Não sei }\end{array}$ & \\
\hline
\end{tabular}

Elaboração própria.

Após a finalização das três primeiras etapas da construção do instrumento (Definição dos conceitos primários e conceitos secundários, identificação de como estes conceitos se manifestam no contexto observado e a especificação dos itens) o questionário produzido passou para etapa seguinte que denominamos de "validação teórica do instrumento", apresentada em detalhes na próxima seção.

\section{3.}

\section{Validação do instrumento}

O processo de validação do instrumento é utilizado para avaliar a eficiência e eficácia do instrumento de pesquisa produzido. A elaboração de um questionário claro, preciso e adequado aos propósitos do estudo é primordial para a assegurar a 
qualidade da pesquisa e a obtenção de dados que serão úteis ao pesquisador. Neste estudo, o processo de validação seguiu as etapas indicadas por Oliveira (2015): a validação dos pares, a análise dos especialistas e o pré-teste assistido. Cada uma das etapas será descrita a seguir.

\subsection{1- A validação dos pares - Grupo de pesquisa}

No dia 06/02/2020 a primeira versão do questionário foi discutida pelos integrantes do grupo de pesquisa GESQ (Gestão e Qualidade na Educação) ${ }^{12}$. No ano de 2014, o grupo participou da construção do Survey GESQ destinado aos diretores, coordenadores e professores, no âmbito da tese de doutoramento da Prof. Ana Cristina Prado de Oliveira e, por esse motivo, alguns integrantes do grupo já possuíam familiaridade com as discussões sobre a construção de instrumentos de pesquisa, o que foi uma contribuição inestimável para o presente estudo.

Outra grande contribuição do grupo se deu pelo fato dos principais temas presentes no instrumento, como clima escolar, participação e autoeficácia, já permearem as discussões do grupo através da leitura de textos, debates e produções de trabalhos sobre as temáticas, como é o caso da tese de doutoramento de Oliveira (2015) que abordou o clima escolar e a de Lima (2019) que utilizou o conceito de autoeficácia no desenvolvimento de sua pesquisa de doutoramento sobre o uso de dados educacionais por parte dos diretores de escolas estaduais de Minas Gerais. Aliado aos estudos teóricos, os membros de grupo possuem uma vasta experiência docente, de gestão e de pesquisa no ambiente escolar, o que se revelou de grande valia na elaboração dos itens que poderiam medir determinados construtos do questionário.

Por fim, a importância de compartilhar o questionário com o grupo de pesquisa se justifica pelo fato da construção de um novo instrumento tem como uma das suas finalidades contribuir para o acervo de instrumentos do grupo, podendo ser utilizado por outros pesquisadores em estudos futuros.

As principais considerações dos integrantes foram em relação ao tamanho do questionário, com indicação para a sua diminuição, à reelaboração e reordenação de alguns itens, com o objetivo de torná-los mais claros e objetivos para os alunos,

\footnotetext{
12 O grupo de pesquisa do Departamento de Educação da PUC-Rio, criado e coordenado pela Prof. Cynthia Paes de Carvalho investiga a gestão nas redes públicas de ensino e a implementação de políticas educacionais para analisar fatores que contribuem para melhorar a qualidade da educação.
} 
à adequação das Escalas Likert e à exclusão de alguns itens que não se mostraram úteis para o objetivo de pesquisa. Após a discussão com o grupo, o questionário foi revisado e modificado com vistas a próxima etapa: a análise dos especialistas.

\subsection{2.}

\section{A análise dos especialistas}

A análise dos especialistas, ou validação de face, é descrita por Cazelli (2005) como o processo em que especialistas "avaliam se os itens que compõem o instrumento operacionalizam de forma adequada os conceitos privilegiados pela pesquisa, ou seja, até que ponto o questionário explicita apropriadamente o que foi particularizado no quadro de referência conceitual" (CAZELLI, 2005, p. 69). A autora ainda reitera que o papel do especialista não é questionar o referencial teórico, mas sim analisar a sintonia do questionário com o quadro de referência conceitual escolhido pelo pesquisador.

Neste estudo, o instrumento produzido foi validado por três especialistas. A escolha desses especialistas se justificou por suas experiências na construção de questionários, no caso das Prof $^{a}$ Ana Cristina Prado de Oliveira (UNIRIO) e da Prof ${ }^{a}$ Naira da Costa Muylaert Lima (PUC-Rio), ou por terem coordenado e implementado pesquisas sobre juventude, como é o caso do Prof. Pedro Pinheiro Teixeira (PUC-Rio). A leitura minuciosa e as considerações detalhadas de cada um dos especialistas trouxeram contribuições muito importantes para a elaboração do questionário. As principais observações estavam relacionadas à redação de algumas questões, que necessitavam de uma maior clareza, e a inversão de algumas escalas, com o objetivo de facilitar a posterior análise dos dados obtidos. Além disso, a Prof. Ana Cristina Prado de Oliveira fez algumas considerações referentes à fase de operacionalização da coleta dos dados, atentando para a necessidade de averiguarmos a atratividade de determinados itens no momento da validação empírica e criação dos índices.

A partir da contribuição dos especialistas, fizemos as modificações no instrumento para torná-lo ainda mais adequado para a nossa pesquisa. Após a revisão do questionário, o passo seguinte foi a realização de um pré-teste assistido com alunos do $9^{\circ}$ ano do Ensino Fundamental, descrito a seguir. 


\subsection{3.}

\section{Pré-teste assistido}

O pré-teste assistido tem como um dos principais objetivos verificar a funcionalidade do instrumento em relação a sua clareza, ao seu vocabulário, ao tempo de preenchimento, às dúvidas e sugestões dos respondentes (OLIVEIRA, 2015). De acordo com Gil (2008, p. 134):

O pré-teste de um instrumento de coleta de dados tem por objetivo assegurarlhe validade e precisão. Como é sabido, no caso do questionário, a obtenção desses requisitos é bastante crítica. Todavia, o pré-teste deve assegurar que o questionário esteja bem elaborado, sobretudo no referente a: a) clareza e precisão dos termos; b) forma de questões; c) desmembramento das questões; d) ordem das questões; e e) introdução do questionário.

Tendo em vista esses objetivos, é importante que os participantes do pré-teste tenham um perfil semelhante ao do público destinatário do instrumento da pesquisa. Em nosso caso, como os jovens do $9^{\circ}$ ano serão os respondentes do instrumento, optamos por realizar o pré-teste assistido com um pequeno grupo de alunos (nove) de escolas públicas do Rio de Janeiro (RJ) e de uma escola particular de São Luís (MA).

A seleção dos alunos e das cidades que participaram do pré-teste foi por critério de conveniência. No momento da realização do pré-teste, em agosto de 2020, já nos encontrávamos na situação de pandemia mundial do COVID-19 com fechamento de todas as unidades escolares e a transferência das aulas presenciais para o formato remoto. Por esse motivo, o planejamento inicial de realização do pré-teste assistido presencialmente precisou ser modificado e readaptado para o formato online. O questionário, que anteriormente seria impresso, também precisou ser transferido para uma plataforma online e, após avaliarmos todos os recursos disponíveis, optamos por utilizar a plataforma Survey Monkey (www.surveymonkey.com), que pareceu atender melhor aos nossos objetivos. Como o pré-teste foi assistido, ao final da aplicação do questionário fizemos uma pequena conversa com os alunos sobre o que eles acharam do instrumento e sobre possíveis dúvidas que tiveram ao respondê-lo.

Os cinco alunos participantes do $9^{\circ}$ ano de uma escola particular de elite de São Luís do Maranhão haviam sido contatados com a ajuda da diretora da escola em que estudam os jovens. Com esses estudantes, o pré-teste assistido foi realizado 
através da plataforma Google Meet no dia 18 de agosto de 2020. A pesquisadora enviou o link de acesso à reunião antecipadamente agendada para os alunos que estavam presentes no dia e hora marcada. Após a explicação do que consistia a pesquisa e sobre a participação deles nessa etapa de pré-teste, os alunos acessaram o link do questionário na plataforma Survey Monkey e responderam as questões no tempo médio de 15 minutos. Depois que todos concluíram o questionário, conversamos sobre as impressões acerca do instrumento e se eles tiveram alguma dúvida ou queriam propor sugestões, mas não houve nenhum questionamento ou sugestão, os alunos apenas demonstraram estarem satisfeitos com o instrumento produzido, afirmando que esse estaria "completo".

No caso dos quatro estudantes do $9^{\circ}$ ano da cidade do Rio de Janeiro, 3 eram alunos de escolas municipais e 1 era aluno de uma escola particular de classe médiabaixa. Os quatro eram alunos de um dos integrantes do grupo de pesquisa que ministra aula em um cursinho preparatório para escolas técnicas de Ensino Médio e também nas redes públicas municipal e estadual de ensino. Devido à baixa qualidade de conexão desse grupo de alunos, não foi possível realizar uma reunião online com eles para realizar o pré-teste assistido. Como solução a esse obstáculo, decidimos enviar o link para acesso ao questionário na plataforma Survey Monkey pelo aplicativo WhatsApp e pedimos para que eles enviassem o feedback sobre o questionário em forma de áudio ou de texto, para que pudéssemos receber e analisar suas impressões sobre o instrumento. A falta de conectividade desses alunos corrobora as discussões levantadas na seção 2.2.1.2 deste trabalho, que apresentou os dados sobre a diferença de acesso à internet móvel entre grupos de grupos sociais distintos, como é o caso dos alunos de escolas particulares e públicas das duas cidades. De volta às respostas do questionário, os alunos das escolas públicas levaram um tempo semelhante aos alunos das escolas particulares para responder ao instrumento (16 minutos) e também alegaram não terem dúvidas sobre os itens presentes no instrumento. Assim como os outros estudantes, ressaltaram que o instrumento estava bem completo.

É importante frisar que, pelo fato de todos os participantes serem menores de idade, foram solicitados os aceites para sua participação aos seus pais e/ou responsáveis, assim como aos próprios estudantes através dos Termo de Consentimento Livre e Esclarecido e Termo de Assentimento Livre e Esclarecido, disponíveis no apêndice D. 
Após a conclusão de todas as etapas de validação teórica do instrumento (validação de pares, avaliação dos especialistas e pré-teste assistido) e da integração das modificações decorrentes das sugestões acatadas ao longo dessas etapas, um novo instrumento de pesquisa foi gerado. Os passos seguintes da finalização do questionário consistiram na aplicação do instrumento em uma amostra significativamente maior de estudantes e, posteriormente, na validação empírica do questionário a partir dos dados coletados, como apresentaremos no próximo capítulo. 


\section{5. \\ Os caminhos de pesquisa em meio a pandemia da COVID 19}

Neste capítulo, primeiramente, apresentamos o processo de seleção da amostra de jovens que participaram da aplicação do questionário, desde o planejamento inicial até as modificações necessárias decorrentes do contexto da pandemia mundial que foi vivido ao longo da realização da pesquisa. Em seguida, será apresentado como se deu a aplicação dos questionários em cada uma das escolas, destacando os caminhos e soluções encontradas tendo vista o contexto de distanciamento ao longo das aplicações. Por fim, apresentamos a validação empírica, última etapa de validação do instrumento de pesquisa, que consiste em avaliar a operacionalização dos itens referentes aos conceitos latentes construídos em escalas. De acordo com Cazelli (2005, p. 78) a validação empírica, ou validação por construção,

(...) refere-se à etapa na qual as variáveis relativas aos conceitos latentes passam por um tratamento analítico que envolve um estudo de dimensionalidade para avaliar se os itens, tidos a priori como os que gerariam as escalas, são confirmados na construção das mesmas.

Essa etapa de validação empírica, no entanto, deve ser realizada após a aplicação do questionário a uma amostra mais ampliada de pessoas. O processo de seleção da nossa amostra será apresentado a seguir.

\section{1.}

\section{A escolha dos jovens e das escolas}

Inicialmente, o nosso planejamento de pesquisa consistia na aplicação presencial do questionário em três escolas distintas no município do Rio de Janeiro, sendo uma instituição pública municipal, uma instituição pública federal e uma instituição privada. O objetivo era analisar a relação dos jovens com as escolas em diferentes contextos organizacionais. No entanto, no início de março de 2020, com o registro da primeira morte no Brasil causada pela Covid-19 foi decretado o fechamento de diversas instituições do país, inclusive escolares, com vistas a conter a propagação do vírus pelo território brasileiro. O fechamento das escolas e a falta de previsão sobre quando elas reabririam nos obrigou a pensar em novas formas de 
desenvolver a pesquisa, tendo em vista que, a priori, não seria mais possível aplicar os questionários presencialmente e as dinâmicas dos processos de autorização de pesquisa por parte da Secretaria Municipal e dos próprios estabelecimentos escolares haviam sofrido modificações, que praticamente impediam a realização da pesquisa conforme planejado.

A primeira preocupação que veio à tona foi em relação ao contato com os alunos das redes públicas de ensino, tendo em vista a grande indisponibilidade de internet por parte desses alunos e o fato de grande parte das escolas não terem dado continuidade ao processo de ensino aprendizagem no formato remoto, como ocorreu na maioria das escolas privadas. Diante desse cenário, nossa primeira ideia foi tentar expandir nossos horizontes de pesquisa, não nos limitando apenas ao município do Rio de Janeiro, a fim de ampliar as chances de conseguir mais respostas do questionário. A ideia de expandir nossa pesquisa para São Luís do Maranhão se deu, em primeiro lugar, pelo fato da autora da pesquisa ter suas raízes na cidade e, por esse motivo, ter contato com alguns diretores escolares daquele município. Em segundo lugar, outra pesquisadora do grupo já estava realizando um estudo na cidade, o que mais uma vez facilitaria a interlocução com os agentes escolares de São Luís do Maranhão.

No dia 03/08/2020 entramos em contato com a Secretaria Municipal de Educação de São Luís- MA para dar entrada no processo de autorização da pesquisa e, no mesmo dia, também entramos em contato com duas diretoras das escolas privadas da mesma cidade para apresentar o projeto de pesquisa. No que se refere às escolas privadas, o aceite para a participação da pesquisa ocorreu na mesma semana, após a apresentação do projeto e os objetivos do estudo para as diretoras de ambas as instituições. A autorização para realização da pesquisa nas escolas públicas por parte da SEMED (Secretaria Municipal de Educação) ocorreu no dia 11/08/2020, com indicação para entramos em contato diretamente com as diretoras das escolas públicas municipais nas quais desejássemos realizar a pesquisa. No dia 12/08/2020 entramos em contato com quatro diretoras das escolas públicas municipais para apresentar o projeto de pesquisa, no entanto, até o dia 20/11/2020 apenas duas haviam respondido nossas mensagens por telefone e e-mails. Após muitas tentativas sem sucesso de acionar as demais gestoras, decidimos seguir a pesquisa com apenas estas duas escolas municipais de São Luís. 
É importante destacar que a seleção das escolas públicas e privadas de São Luís que fariam parte da nossa pesquisa foi por critério de conveniência, tendo em vista que escolhemos as instituições públicas que já estavam participando de outra pesquisa do grupo e, por isso, já tínhamos um contato prévio com elas e, no caso das privadas, a autora deste trabalho conhece há muitos anos as diretoras das duas instituições.

No que se refere ao município do Rio de Janeiro - RJ, no dia 24/07/2020 enviamos o projeto de pesquisa à Secretaria Municipal de Ensino (SME-RJ) e para o Comitê de Ética da instituição Federal que desejávamos estudar. Ambos os processos foram extremamente demorados, sendo que até o fim desta pesquisa não recebemos retorno da instituição federal, mesmo após diversos contatos por telefone e e-mail. No caso da Secretaria Municipal de Educação do Rio de Janeiro, no dia 24/10/2020 recebemos a resposta de que a realização da pesquisa com os alunos não havia sido autorizada com a justificativa de que as escolas estariam passando por um momento difícil devido à pandemia e que poderíamos tentar realizar o estudo depois que as aulas presenciais voltassem a acontecer. Na escola privada do Rio de Janeiro, o primeiro contato de solicitação da pesquisa foi realizado no dia 27/07/2020 com o diretor do estabelecimento que é doutorando da PUC-Rio e também integra o GESQ. No dia 14/09/2020 fizemos uma reunião com duas coordenadoras da instituição para apresentar os objetivos do estudo e discutir a realização da pesquisa no contexto online, tendo em vista que aulas presenciais na rede privada de ensino ainda estavam suspensas.

Ao final de todo o processo, conseguimos aplicar o questionário em 2 escolas públicas e 2 escolas privadas de São Luís (MA) e uma escola particular do Rio de Janeiro (RJ), totalizando 5 instituições e 224 respondentes. Na próxima seção, descrevemos mais detalhadamente as características de cada uma das instituições assim como os caminhos que utilizamos para acessar os alunos de $9^{\circ}$ ano dessas escolas, tendo em vista que cada uma delas estava experienciando uma realidade diferente diante da pandemia mundial causada pelo Corona Vírus.

\section{2.}

\section{Os desafios na aplicação do questionário no contexto da pandemia}

O processo de aplicação dos questionários em meio ao contexto da pandemia e do fechamento das instituições escolares foi um dos maiores desafios encontrados 
em nossa pesquisa. Ao nos depararmos com a falta de previsão para a volta às aulas presencial, começamos a pensar em soluções para dar continuidade em nossa pesquisa tentando minimizar os impactos da pandemia na qualidade do nosso estudo. Apesar de ter a consciência de que os caminhos encontrados não são os ideais para a aplicação de um survey e esse fato pode ter ocasionado o baixo número de respostas dos alunos, principalmente nas instituições públicas de ensino, também compreendemos que diante da magnitude do contexto que estávamos vivendo, esses caminhos foram os melhores encontrados por nós pesquisadores.

Como veremos a seguir, nas duas escolas privadas de São Luís do Maranhão em que conseguimos aplicar o questionário presencialmente, tivemos o maior percentual de resposta dos alunos, o que nos mostra um dos principais benefícios da aplicação de questionário face-a-face. Por outro lado, nas duas escolas públicas em que tivemos que usar o aplicativo WhatsApp como meio para acessar os alunos, o percentual de respostas foi o mais baixo, o que demonstrou a baixa eficácia desse instrumento na realização da nossa pesquisa. No entanto, devemos considerar que o baixo percentual de resposta dos alunos da rede pública de ensino pode estar associado a precariedade do acesso à internet nas camadas mais populares da nossa sociedade e qualquer outra solução encontrada, que não a presencial, poderia enfrentar os mesmos obstáculos.

Sobre o dilema da aplicação de questionários online ou presencial, alguns autores discutem os benefícios e malefícios na utilização de cada uma das abordagens. De acordo com Couper e Miller (2008), as principais vantagens do questionário online está relacionado ao custo reduzido da aplicação do instrumento via web e a rapidez do processo de coleta de dados, sendo possível obter mais dados em um curto espaço de tempo. Por outro lado, Holbrook, Green e Krosnick (2003) argumentam que nos questionários respondidos via web os respondentes teriam mais chances de utilizarem a opção "não sei”, de responderem igualmente todos os itens (no caso de escalas) e de deixar respostas em branco se comparado aos respondentes da abordagem "face-a-face". De qualquer forma, no caso desta pesquisa, utilizamos as duas abordagens, naquelas escolas em que as aulas já haviam voltado presencialmente conseguimos aplicar para a maior parte dos alunos "face-a-face" e nas outras que as aulas continuavam no formato remoto, tivemos que aplicar via web. A seguir descrevemos o processo de aplicação realizado em cada uma das cinco instituições. 


\subsection{1.}

\section{Os jovens e as escolas em São Luís do Maranhão}

\section{$\underline{\text { A aplicação do questionário nas escolas privadas } A \text { e } B}$}

Nas duas escolas privadas de São Luís (MA) o processo de aplicação dos questionários aos alunos do $9^{\circ}$ ano do Ensino Fundamental foi bem semelhante, provavelmente pelo fato das duas escolas fazerem parte de um mesmo grupo educacional e, por esse motivo, possuírem organização e regimento parecidos. Ambas voltaram às aulas presenciais a partir do dia 03/08/2020 atentas a todos os protocolos de saúde e com uma estratégia de rodízio nas turmas, em que em uma semana uma parte dos alunos ia para aula presencial e na outra ficava em casa e acompanhava as aulas através de uma transmissão ao vivo do que estava acontecendo em sala, na semana seguinte os grupos efetuavam o rodízio. No que se refere à aplicação do questionário, as diretoras das duas instituições autorizaram a entrada da pesquisadora na escola para realizar a pesquisa, no entanto, devido à diferença no número de alunos matriculados no $9^{\circ}$ ano de cada uma das escolas, algumas estratégias de aplicação do instrumento foram diferentes, como descreveremos a seguir.

A escola A é uma escola bilingue canadense, localizada em um bairro de classe média/média alta no município de São Luís e atende alunos oriundos de famílias de classe alta, sendo atualmente a instituição de ensino com maior valor de mensalidade da cidade. A escola, que possui 10 anos de existência, atende cerca de 900 alunos desde o maternal até o ensino médio, sendo o $9^{\circ}$ ano composto de uma turma de 24 alunos. No que se refere a sua organização, o quadro de gestão da escola é composto por uma diretora geral, uma coordenadora pedagógica geral, uma coordenadora pedagógica para cada segmento (educação infantil, ensino fundamental I e ensino fundamental II e ensino médio) e uma orientadora educacional, que lida com demandas mais específicas dos alunos.

Para a realização da pesquisa apresentamos o projeto em uma reunião com a diretora geral, a coordenadora pedagógica e a orientadora educacional. Posteriormente a orientadora educacional acompanhou mais de perto a aplicação dos questionários aos alunos. Após conversamos sobre as possibilidades de aplicação do instrumento, ficou acordado que ela seria realizada em duas semanas distintas, tendo em vista que os alunos estavam organizados em dois grupos que se revezavam entre as aulas presenciais e as aulas remotas a cada semana. Na semana 
1 aplicamos o questionário para os 12 alunos então presentes e na semana 2 aplicamos para os outros 12 alunos. Nos dois casos a totalidade da aplicação foi presencial e todos os alunos concluíram o questionário. Como a escola possuía tablet disponíveis para todos os alunos, optamos por disponibilizar o link para os alunos acessarem o questionário online na plataforma Survey Monkey, sendo assim, apesar da aplicação "face-a-face" ainda utilizamos a plataforma online para disponibilizar o instrumento aos respondentes. A aplicação durou o total de 30 minutos, sendo os 10 minutos iniciais destinados à apresentação da pesquisa e do instrumento para os alunos e o restante para os jovens responderem ao instrumento.

A escola $B$ localiza-se no mesmo bairro de classe média/média-alta da escola A, no entanto, não é bilingue e sua mensalidade é inferior à da escola $\mathrm{A}$. A instituição é mais tradicional na cidade, com 35 anos de existência, e atende cerca de 1.900 alunos do maternal I ao ensino médio. No que se refere ao $9^{\circ}$ ano, ela possui um número de alunos matriculados consideravelmente maior em comparação à escola $\mathrm{A}$, sendo 152 alunos distribuídos em 5 turmas. Em relação à organização da escola, existe uma diretora geral, uma diretora pedagógica e cada segmento possui uma coordenadora pedagógica e uma coordenação de tutoria, que cuida da parte relacional dos alunos. Para a realização da pesquisa, conversamos apenas com a diretora geral da instituição, no entanto, no dia da aplicação, a coordenadora tutora do Ensino Fundamental II nos acompanhou na entrada nas turmas.

Devido à grande quantidade de alunos e de turmas de $9^{\circ}$ ano na instituição, foi preciso adotar uma estratégia distinta da formulada para a escola A. Na escola B, aplicamos o instrumento nas cinco turmas em apenas um dia da semana e em dois turnos distintos, de manhã e à tarde. Os alunos que estavam presentes em sala de aula no momento da aplicação responderam ao questionário "face-a-face" e aqueles que estavam em casa ouviram as orientações através da transmissão ao vivo e responderam ao questionário em casa, através do link do Survey Monkey que foi disponibilizado por meio do chat do aplicativo em que estava acontecendo a transmissão ao vivo. A aplicação durou o total de 35 minutos, sendo 10 minutos para apresentação da pesquisa e do instrumento e 25 minutos o tempo que todos os alunos, tanto os que estavam em casa, como os que responderam presencialmente, levaram para finalizar o instrumento. Do total de 152 alunos que compunham as turmas do $9^{\circ}$ ano desta escola, 108 responderam ao questionário ( $71 \%$ do total). 
No momento da aplicação dos questionários em ambas as escolas, algumas dúvidas sobre os itens surgiram, principalmente sobre as perguntas que buscavam medir a participação discente no espaço escolar. Nas duas escolas dois alunos perguntaram o que seria "grêmio estudantil". Na escola B um aluno perguntou o que era um "coletivo" e na escola A uma aluna pediu para que esclarecêssemos o que seria "movimento estudantil". Essas dúvidas, que não apareceram no momento do pré-teste assistido do instrumento, apontaram para a necessidade de maior reflexão sobre a adequação da linguagem do questionário e a provável necessidade de conhecer em que medida a participação dos alunos era uma questão realmente significativa naquelas escolas, assim como se o tema era debatido ou valorizado dentro dessas instituições.

\section{A aplicação dos questionários nas escolas públicas $C$ e $D$}

Até o momento de finalização da etapa de coleta de dados da nossa pesquisa, no início do mês de novembro de 2020, as aulas nas instituições públicas de ensino de São Luís (MA) não haviam voltado presencialmente e, de acordo com as diretoras das duas escolas contatadas, os alunos não tiveram aulas remotas de forma sistematizada no decorrer da pandemia. Segundo as gestoras, os professores das escolas decidiam como dariam prosseguimento ao processo de ensinoaprendizagem dos alunos, tendo em vista que não havia uma regulamentação da Secretaria Municipal de Educação sobre como as escolas e professores deveriam agir. Nessas condições, conversamos com as diretoras sobre a melhor forma de aplicar os questionários, já que não seria possível fazê-la presencialmente. A solução encontrada foi enviar o instrumento pelo aplicativo WhatsApp para o grupo que reunia todos os alunos do $9^{\circ}$ ano com o auxílio das diretoras (que participavam do grupo dos alunos), acompanhado de um vídeo e uma mensagem da pesquisadora explicando os objetivos do estudo e a importância de os alunos colaborarem com a pesquisa. Infelizmente, menos da metade dos alunos respondeu (40\% do total de alunos matriculados no $9^{\circ}$ ano na escola $C$ e de apenas $15 \%$ na escola $\left.D\right)$. Como já observamos no capítulo 2, a falta de conexão de internet dos alunos das escolas públicas é uma realidade que se apresenta em grande parte do Brasil, e o baixo número de respostas parece confirmar isso.

Em relação às características de cada uma das escolas públicas de São Luís, foi possível encontrar algumas informações na base de dados do Censo Escolar de 
2018 e da Prova Brasil de $2017^{13}$ que ajudam a contextualizar o perfil de cada uma das instituições. A escola $C$ localiza-se em um bairro de classe média-baixa do município de São Luís (MA), possui 1.445 alunos matriculados desde a Educação Infantil até o Ensino Fundamental II. De acordo com a diretora da escola no ano de 2020, o $9^{\circ}$ ano do Ensino Fundamental II contava no início do período letivo com 57 alunos matriculados, desse total, 23 responderam ao nosso questionário (40,35\% do total). Em relação as taxas de reprovação e de distorção idade-série do último ano do Ensino Fundamental II, os dados do Censo Escolar referentes ao ano de 2018 apontam $24 \%$ dos alunos matriculados no $9^{\circ}$ ano tinham um atraso escolar de 2 anos ou mais. Os dados que se referem à aprendizagem dos alunos em matemática e português, obtidos através das avaliações da Prova Brasil no ano de 2017, apontam que $30 \%$ dos alunos que cursavam o $9^{\circ}$ ano da escola $C$ naquele ano aprenderam o adequado na competência de leitura e interpretação de textos (língua portuguesa) e apenas 7\% aprenderam o adequado na competência de resolução de problemas (matemática) até o $9^{\circ}$ ano.

A escola $D$, por sua vez, também se localiza em um bairro de classe médiabaixa do município de São Luís (MA) e possui 1.425 estudantes distribuídos desde a Educação Infantil até o Ensino Fundamental II. Apesar da escolar possuir um número superior de alunos matriculados no $9^{\circ}$ ano do Ensino Fundamental (91 estudantes) em comparação com a escola $C$, a quantidade de respondentes foi significativamente menor, apenas 14 alunos (15,3\% do total de estudantes matriculados nessa série). No que se refere aos índices da instituição, tanto as taxas de reprovação e distorção idade-série, como as de aprendizado no $9^{\circ}$ ano se mostraram melhores que as da escola $C$ : no ano de 2018, os dados do Censo Escolar apontam um percentual de $10 \%$ dos alunos do $9^{\circ}$ ano que estavam com atraso escolar de 2 anos ou mais. Já os dados da Prova Brasil de 2017 revelaram que 64\% dos alunos aprenderam o adequado na disciplina de Português e 19\% na disciplina de Matemática. É importante frisar que, em ambas as escolas, não foram os alunos participantes da nossa pesquisa que foram avaliados pela Prova Brasil, ainda que se possa esperar um perfil semelhante.

A partir dessa contextualização realizada através dos dados do Censo Escolar de 2018 e da Prova Brasil de 2017 podemos concluir que as duas escolas presentes

${ }^{13}$ Dados extraídos do site Qedu: https://www.qedu.org.br/. Acesso em: 19/11/2020 
na amostra apesar de terem grande semelhança em termos de tamanho e infraestrutura, diferem em relação aos resultados de reprovação, distorção idadesérie e aprendizado, sendo que a escola $D$ apresentou resultados superiores à escola $C$ em todos os aspectos mencionados. Esses dados são importantes para a nossa pesquisa pois podem contribuir para compreender as respostas referentes ao clima escolar, a participação e percepção de autoeficácia em ambas as escolas.

\subsection{2.}

\section{Os jovens e a escola no Rio de Janeiro (RJ)}

Como dito anteriormente, a pesquisa nas escolas municipais da cidade do Rio de Janeiro não foi autorizada pela Secretária Municipal de Educação, como era o plano inicial. Além disso, a instituição federal que também participaria da aplicação do instrumento não respondeu à nossa solicitação de autorização de pesquisa, apesar de muitas tentativas de contato via telefone e e-mail. Devido ao curto espaço de tempo que tínhamos para coletar os dados, conseguimos aplicar o questionário em apenas uma escola particular da cidade, como descreveremos nesta seção.

A escola particular do Rio de Janeiro presente em nossa amostra foi escolhida por critério de conveniência, pelo fato de um dos diretores da escola ser membro do nosso grupo de pesquisa e ter aceitado participar da pesquisa previamente. Devido à pandemia e ao fato da escola ainda estar com aulas remotas no momento de coleta dos dados, foi preciso ajustar a dinâmica de aplicação dos questionários que, em um primeiro momento, seria presencial. Após uma conversa com o gestor e com as coordenadoras da instituição, decidimos que o questionário seria aplicado em um momento de aula através da plataforma Zoom. Sendo assim, no dia 25/09/2020 a pesquisadora entrou na sala virtual em que os alunos do $9^{\circ}$ ano estavam presentes para explicar sobre a pesquisa, seus objetivos e a importância dos alunos participarem do estudo e, em seguida enviar o questionário (presente na plataforma Survey Monkey) através do chat da plataforma. Nessa escola, a aplicação durou 40 minutos, contando com o momento de contextualização da pesquisa, e, diferentemente das escolas A e B, não surgiram dúvidas em relação aos itens presentes no instrumento.

A escola localiza-se na Zona Sul da cidade, em um bairro de classe média/média alta do município e possui cerca de 1300 alunos matriculados da Educação Infantil ao Ensino Médio. Mais especificamente no $9^{\circ}$ ano do Ensino 
Fundamental II, a escola possui 76 alunos matriculados dos quais 53 (69\% do total de estudantes matriculados nessa série) participaram da nossa pesquisa. Trata-se de uma escola internacional (vinculada ao governo alemão), que possui 1 diretor brasileiro, 1 diretor interino alemão, 1 vice-diretora brasileira, 1 gestor administrativo financeiro brasileiro. As coordenações de cada segmento são divididas entre os ramos alemão e brasileiro e cada segmento possui uma orientadora educacional brasileira e uma alemã.

Finalizamos a fase de coleta dos dados na segunda semana de novembro de 2020 conseguindo aplicar o instrumento desenvolvido para 224 alunos do $9^{\circ}$ ano do Ensino Fundamental de 5 escolas públicas e privadas localizadas nos municípios de São Luís do Maranhão e Rio de Janeiro. Após a coleta de dados, seguimos para a fase de validação empírica do instrumento descrita a seguir.

\section{3.}

\section{A validação empírica do questionário}

Como mencionado na seção anterior, utilizamos a plataforma Survey Monkey para aplicar o nosso instrumento de pesquisa aos jovens de escolas públicas e privadas. Após a coleta de 224 respostas, extraímos os dados coletados da plataforma e transferimos para o IBM SPSS Statistics 20, software escolhido para a realização da nossa validação empírica e, posteriormente, para a análise exploratória dos dados. É importante frisar que nessa fase de validação empírica procedemos à operacionalização dos itens, ou seja, a etapa 5 do processo de elaboração de um instrumento descrito por Oliveira (2015).

De acordo com Cazelli (2005, p. 78) na validação empírica ou validação por construção, as variáveis relativas aos conceitos latentes passam por um tratamento analítico para verificar sua dimensionalidade para confirmar se os itens do instrumento que comporiam a variável latente de fato se associam numa determinada dimensão definindo uma escala consistente para mensurar a variável ou não. Trata-se assim de uma etapa responsável por auxiliar a construção de escalas confiáveis para mensurar e analisar os dados coletados. Segundo Cazelli (2005), uma das principais vantagens da construção de escalas para a análise de dados é a possibilidade de dimensionar um conceito complexo a partir de vários itens. O clima escolar é um bom exemplo de um conceito complexo que seria impossível de medir a partir de apenas um item, tendo em vista a multiplicidade de 
dimensões que envolvem este construto. Dessa forma, elaboramos diversos itens que serão operacionalizados em escalas (ou índices) que buscam dimensionar o clima das instituições pesquisadas. Além do clima escolar, no caso da nossa pesquisa, a construção do nosso instrumento possibilitou a elaboração de escalas para dimensionar a mobilização dos alunos em relação à escola, a participação discente e a autoeficácia dos alunos.

Para a construção das escalas e avaliação da sua unidimensionalidade, utilizamos o procedimento analítico denominado Análise de Fatores, como indicado por Cazelli (2005) e Oliveira (2015). De acordo com Oliveira (2015), a análise de fatores é uma técnica comumente utilizada para a construção e validação (ou descarte) de itens, pois através dela é possível avaliar se os itens elaborados estão verdadeiramente medindo um determinado construto: se a carga fatorial do item for muito baixa isso significa que ele não está contribuindo para dimensionar o fator (ou construto) em questão e poderá ser eliminado. A técnica de análise de fatores, além de outros benefícios, é importante para tornar o instrumento mais eficaz na mensuração do fenômeno pesquisado. Para atestar a existência de uma correlação suficientemente forte para que a análise fatorial possa ser aplicada, utilizamos a medida de KMO (Kaiser-Meyer-Olkin). De acordo com Kaiser (1997) o valor obtido no teste deve ser maior que 0,5 para que a associação entre os fatores possa ser considerada estatisticamente adequada ao fenômeno (variável latente) que se pretende mensurar.

Após a construção dos índices, testamos a sua confiabilidade através de uma medida denominada Alpha de Cronbach, responsável por mensurar a consistência interna das escalas baseada na média de correlação entre os itens (OLIVEIRA, 2015; CAZELLI, 2005). De acordo com Field (2011) uma alta confiabilidade significa que a escala construída está, consistentemente, refletindo o construto que está medindo. Como valor de referência, a literatura indica que um valor de Alpha de Cronbach acima de 0,70 é ótimo e entre 0,70 e 0,60 é aceitável. No entanto, Cortina (1993) atenta para o fato de que o número de itens que compõe a escala influencia o valor de alpha, sendo assim, uma escala composta por poucos itens pode resultar em um valor de Alpha de Cronbach baixo e não necessariamente isso está relacionado com fidedignidade do índice.

Durante essa fase de validação empírica, também denominada de operacionalização dos itens (OLIVEIRA, 2015), alguns dos blocos de questões 
inicialmente pensados como adequados para a criação de índices não se se confirmaram como tal, como no caso dos blocos de questões que buscavam mensurar as dimensões "relações interpessoais" e "segurança física e emocional no espaço escolar" do clima escolar.

No que se refere às relações interpessoais, o índice resultou em um Alpha de Cronbach muito baixo e, por isso, decidimos avaliar essa dimensão apenas calculando a distribuição percentual de alunos das escolas públicas e privadas por resposta. Uma possível explicação pode estar relacionada ao momento de aplicação do instrumento de pesquisa, em meio a pandemia da Covid-19, que afastou os alunos da escola e do convívio com os atores escolares. Esse fato pode ter enviesado a resposta dos alunos em relação a qualidade das suas relações interpessoais dentro do espaço escolar e ter contribuído para a baixa confiabilidade do índice. Em relação à dimensão da segurança física e emocional na escola, a análise fatorial resultou na criação de um índice de apenas dois itens com cargas fatoriais idênticas, o que indicava que poderíamos reduzir os dois itens em apenas um. Por esse motivo, também decidimos analisar a dimensão através da distribuição percentual das respostas dos alunos. Os resultados relativos a ambos os índices eliminados encontram-se no apêndice B.

A seguir apresentaremos os índices criados e que serão usados na análise exploratória dos nossos dados.

\subsection{1.}

\section{Índices de mobilização em relação à escola}

Como apontado no Capítulo 3 deste trabalho, a literatura indica que existem diversos fatores capazes de mobilizar os jovens em relação à escola. Através dos itens criados para o nosso instrumento pretendíamos conhecer quais são os motivos que mobilizam os jovens da nossa amostra a irem para escola. Como já era esperado, tendo em vista a diferença de conteúdo entre os itens (alguns mais voltados para aspectos relativos à aprendizagem, outros para a realização de projetos futuros e outros para a sociabilidade) e a própria literatura sobre jovens e escolas, a análise fatorial apontou para a construção de três índices: o primeiro reunia itens sobre a mobilização do aluno em relação à escola voltados para a aprendizagem (Índice de mobilização do aluno para aprendizagem), o segundo índice reunia itens que tratavam da mobilização do aluno em relação à escola com 
vistas ao seu futuro (Índice de mobilização do aluno para projetos futuros) e, por fim, o último índice reunia os itens que relacionavam a mobilização do aluno para ir à escola com a socialização (Índice de mobilização do aluno para a socialização).

Após a criação dos três índices de mobilização (para a aprendizagem, para projetos futuros e para a socialização), refizemos as análises fatoriais de cada um dos índices, individualmente, para confirmação do KMO, o Alpha de Cronbach e a variância explicada específicos de cada um desses índices. Os quadros apresentados mais adiante mostram os resultados obtidos.

É importante salientar que um único item "Vou à escola porque sou obrigado" precisou ser excluído de nossas análises porque se mostrou pouco relacionado com os demais itens a partir da análise fatorial realizada, obtendo uma carga fatorial muito abaixo das demais.

Tabela 1 - Resultado da análise fatorial e do teste de confiabilidade interna para o índice de mobilização do aluno para a aprendizagem.

\section{Índice de mobilização do aluno para a aprendizagem}

Variável: Pense nos motivos pelos quais você vai para a escola. Marque qual é o seu nível de concordância com cada uma das afirmativas abaixo:

Vou à escola porque gosto de aprender.

Carga Fatorial

Vou à escola porque me interesso por alguma disciplina.

0,732

Vou à escola porque gosto dos professores.

0,585

Vou à escola porque é o meu direito.

0,682

$\begin{array}{rr}\text { Variância explicada } & 45,6 \% \\ \text { KMO } & 0,592\end{array}$

Alpha de Cronbach

0,587

Nota: Extraído pelo método de Análise de Componentes Principais (PCA) com rotação Varimax. Fonte: Questionário “Jovens e escolas: quais as relações?”. Elaborado pela autora.

Como pode ser observado na tabela acima, o Índice de mobilização do aluno para aprendizagem obteve baixos valores de KMO e Alpha de Cronbach, o que demonstra a necessidade de, futuramente, revisarmos os itens que compõem esse índice, com o objetivo de torná-lo mais confiável para as análises. Contudo, o baixo número de respondentes também pode ser visto como um fator que contribuiu para esse resultado. De toda forma, a centralidade da discussão sobre a relação dos jovens com as aprendizagens escolares no âmbito das pesquisas sobre juventude e 
escola justifica a opção por manter a utilização desse índice nas análises exploratórias que serão apresentadas no capítulo 6 deste trabalho.

No Índice de mobilização do aluno para projetos futuros apresentado a seguir, observamos que a eliminação do item "Vou à escola para ter melhores condições de vida do que meus pais" resultaria em um Alpha de Cronbach maior $(0,759)$ do que se todos os itens estivessem presentes. Possivelmente a explicação para isso está relacionada ao número superior de alunos de escolas privadas que responderam ao nosso questionário e que, por seus pais já possuírem boas condições financeiras, não sentem necessidade de alcançar melhores condições que seus pais. Isso explicaria o fato do índice ter se apresentado como pouco explicativo. No entanto, como nosso intuito com a elaboração deste questionário também era aplicá-lo a jovens de diferentes grupos sociais e econômicos, decidimos não retirar o item.

Tabela 2: Resultado da análise fatorial e do teste de confiabilidade interna para o Índice de mobilização do aluno para projetos futuros.

\section{Índice de mobilização do aluno para projetos futuros}

Variável: Pense nos motivos pelos quais você vai para a escola. Marque qual é o seu nível de concordância com cada Carga Fatorial uma das afirmativas abaixo:

Vou à escola porque acho importante para conseguir um trabalho futuramente.

Vou à escola para tentar entrar na faculdade/ensino superior. 0,794

Vou à escola para ter melhores condições de vida do que meus pais/responsáveis

$\begin{array}{rr}\text { Variância explicada } & 61 \% \\ \text { KMO } & 0,605\end{array}$

Alpha de Cronbach

0,620

Nota: Extraído pelo método de Análise de Componentes Principais (PCA) com rotação Varimax. Fonte: Questionário “Jovens e escolas: quais as relações?”. Elaborado pela autora. 
Tabela 3: Resultado da análise fatorial e do teste de confiabilidade interna para o índice de mobilização do aluno para socialização.

\section{Índice de mobilização do aluno para a socialização}

Variável: Pense nos motivos pelos quais você vai para a escola. Marque qual é o seu nível de concordância com cada uma das afirmativas abaixo:

Vou à escola para encontrar com os amigos. $\quad 0,790$

Vou à escola porque gosto do intervalo.

0,758

Variância explicada $\quad 67,3 \%$

KMO $\quad 0,500$

Alpha de Cronbach $\quad 0,512$

Nota: Extraído pelo método de Análise de Componentes Principais (PCA) com rotação Varimax. Fonte: Questionário "Jovens e escolas: quais as relações?". Elaborado pela autora.

Por fim, o Índice de mobilização do aluno para a socialização apresentado acima teve o menor valor de Alpha de Cronbach, contudo, decidimos mantê-lo tendo em vista as pesquisas sobre juventude e escola mencionadas no capítulo 3 deste trabalho e que atentam para o fato de muito jovens irem para escola e permanecerem estudando por causa dos laços que criaram com seus pares dentro do ambiente escolar. No entanto, as cargas fatoriais muito próximas $(0,790$ e 0,758$)$ apontam para a similitude dos dois itens, indicando que a exclusão de um deles poderia não trazer prejuízos para o instrumento. De fato, podemos supor que a grande parte daqueles que vão para escola porque gostam do intervalo também vão para a escola para encontrar os amigos, já que o intervalo é um momento de encontro entre os pares.

\subsection{2.}

\section{Índices que compõem a medida de clima escolar}

Como já mencionado, o clima escolar é um construto amplo e que envolve diferentes dimensões, por esse motivo, o resultado da análise fatorial para a criação de diferentes índices que medissem as distintas dimensões do clima escolar era especialmente importante para nós. $\mathrm{O}$ fato de alguns itens poderem compor uma ou outra dimensão tornou o processo de análise de fatores ainda mais essencial nesse caso. Um exemplo disso foi o item "Na minha escola os alunos respeitam e valorizam os professores" que em um primeiro momento inserimos na dimensão "Segurança Física e Emocional”, porém alcançou uma carga fatorial bem maior 
quando inserido na dimensão "Relações interpessoais" indicando que a percepção dos alunos sobre o respeito e valorização dos professores deve guardar associações mais intensas com a forma como as relações se estabelecem dentro do espaço escolar do que cada dimensão de segurança física e emocional do clima escolar.

Ao final processo de análise fatorial, testando diferentes composições de itens relacionados ao construto "Clima escolar" foram criados 8 índices que serão apresentados nas tabelas a seguir, junto com a carga fatorial de cada item e as medidas de Alpha de Cronbach e KMO de cada uma das escalas.

1) Índice de percepção dos alunos sobre a infraestrutura:

A literatura sobre clima escolar aponta que a infraestrutura das escolas é um dos aspectos que influencia a atmosfera da escola (COHEN et al., 2009; THAPA et al, 2013; VINHA et al., 2017). O índice construído mede a percepção dos alunos sobre os espaços físicos do ambiente escolar em termos de conforto, limpeza, preservação, recursos materiais e adequação dos espaços. Principalmente em países como o Brasil, em que existe uma grande diferença entre as escolas em relação ao seu espaço físico, os estudos apontam a importância desse aspecto inclusive para aprendizagem dos alunos (ALVES e FRANCO, 2008).

Tabela 4: Resultado da análise fatorial e do teste de confiabilidade interna para o índice de percepção dos alunos sobre a infraestrutura.

\section{Índice de percepção dos alunos sobre a infraestrutura}

Variável: Pense na escola em que você estuda. Marque qual é o seu nível de concordância com cada uma das afirmativas abaixo:

A minha escola oferece um ambiente favorável para todos aprenderem.

Na minha escola, as salas de aula são confortáveis, limpas e preservadas.

Carga Fatorial

Na minha escola, há biblioteca com livros variados.

Na minha escola, os espaços utilizados durante o intervalo e para a convivência são adequados.

$\begin{array}{rr}\text { Variância explicada } & 60,7 \% \\ \text { KMO } & 0,768 \\ \text { Alpha de Cronbach } & 0,774\end{array}$

Nota: Extraído pelo método de Análise de Componentes Principais (PCA) com rotação Varimax. Fonte: Questionário “Jovens e escolas: quais as relações?”. Elaborado pela autora. 
2) Índices de Percepção do Ambiente acadêmico:

A análise fatorial dos itens que compunham a dimensão "Processos de ensino aprendizagem" resultou na criação de dois índices diferentes: o primeiro reuniu itens relacionados ao interesse do professor na aprendizagem dos alunos (oferecer ajuda extra, corrigir o dever de casa, perguntar se os alunos entenderam o que foi ensinado) e, por isso, o denominamos de Índice de percepção dos alunos sobre o compromisso do professor com a aprendizagem; e o segundo reuniu os itens relacionados à indisciplina em sala de aula (não deixar o professor falar, muita desordem e confusão) e foi denominado Índice de indisciplina em sala de aula. No que se refere a esse construto a análise fatorial também foi importante para eliminarmos o item "Os professores mandam deveres de casa" que apresentou carga fatorial extremamente baixa em relação aos demais itens. Devido a criação de dois índices distintos para a mensuração do mesmo construto, refizemos as análises fatoriais com vistas a buscar conhecer o KMO, o Alpha de Cronbach e a variância explicada específicas cada um dos índices. As tabelas a seguir mostram os resultados obtidos.

Tabela 5: Resultado a análise fatorial e do teste de confiabilidade interna para o Índice de percepção dos alunos sobre o compromisso do professor com a aprendizagem.

\section{Índice de percepção dos alunos sobre o compromisso do professor com a} aprendizagem

Variável: Considerando a maioria das suas aulas, indique a frequência com que estas coisas acontecem na sua escola:

Os professores demonstram interesse na aprendizagem de todos os alunos.

Carga Fatorial

Os professores corrigem os deveres de casa. $\quad 0,513$

Os professores oferecem ajuda extra para todos os alunos com dificuldade de aprender.

Os professores fazem perguntas para saber se os alunos entenderam o que foi ensinado

Os professores me falam como posso melhorar meu desempenho escolar.

Os professores encorajam os alunos a expressarem a sua opinião sobre os temas estudados. 0,714

Os professores apoiam e incentivam os alunos a participarem ativamente.

$\begin{array}{rr}\text { Variância explicada } & 45,9 \% \\ \text { KMO } & 0,827\end{array}$

\section{Alpha de Cronbach

Nota: Extraído pelo método de Análise de Componentes Principais (PCA) com rotação Varimax. Fonte: Questionário "Jovens e escolas: quais as relações?". Elaborado pela autora. 
Tabela 6: Resultado da análise fatorial e do teste de confiabilidade interna para o índice de indisciplina em sala de aula.

Índice de indisciplina em sala de aula

Variável: Considerando a maioria das suas aulas, indique a frequência com que estas coisas acontecem na sua escola:

Carga Fatorial

Os alunos não escutam o que os professores dizem. $\quad 0,755$

Há desordem e confusão em sala de aula. $\quad 0,815$

Os professores precisam esperar um longo tempo para os

alunos ficarem em silêncio.

$\begin{array}{rr}\text { Variância explicada } & 62.2 \% \\ \text { KMO } & 0,664\end{array}$

Alpha de Cronbach $\quad 0,697$

Nota: Extraído pelo método de Análise de Componentes Principais (PCA) com rotação Varimax. Fonte: Questionário “Jovens e escolas: quais as relações?". Elaborado pela autora.

3) Índice de percepção dos alunos sobre sua relação de pertencimento ao espaço escolar:

$\mathrm{O}$ Índice de percepção dos alunos sobre sua relação de pertencimento ao espaço escolar, busca medir em que medida os alunos se sentem como membros de uma comunidade, no caso de sua escola, e se sentem valorizados pelos sujeitos que atuam nesse espaço. Este índice apresentou o maior Alpha de Cronbach de todos os índices que mediam o clima escolar $(0,799)$, o que indica que os itens construídos são altamente confiáveis para medir o nível da relação de pertencimento dos alunos em relação às suas escolas. Na tabela a seguir são apresentados os itens que compõem o índice e suas respectivas cargas fatoriais. 
Tabela 7: Resultado a análise fatorial e do teste de confiabilidade interna para o índice de percepção dos alunos sobre a sua relação de pertencimento ao espaço escolar.

\section{Índice de percepção dos alunos sobre a sua relação de pertencimento ao} espaço escolar.

Variável: Pense na escola em que você estuda. Marque qual é o seu nível de concordância com cada uma das afirmativas Carga Fatorial abaixo:

\begin{tabular}{lc}
\hline Gosto de estudar na minha escola. & 0,738 \\
\hline $\begin{array}{l}\text { Na minha escola, sinto que todos estão atentos às minhas } \\
\text { necessidades. }\end{array}$ & 0,779 \\
\hline Tenho orgulho de ser aluno da minha escola. & 0,844 \\
\hline Na minha escola, sinto que sou valorizado por todos. & 0,799 \\
\hline Variância explicada & $62,5 \%$ \\
KMO & 0,726
\end{tabular}

Alpha de Cronbach $\quad 0,799$

Nota: Extraído pelo método de Análise de Componentes Principais (PCA) com rotação Varimax. Fonte: Questionário “Jovens e escolas: quais as relações?”. Elaborado pela autora.

4) Índice de percepção dos alunos sobre as regras da escola:

Outro aspecto relativo ao clima escolar que escolhemos mensurar foi a percepção dos alunos sobre as regras e sanções da escola. A revisão de literatura indicou a centralidade desse fator para analisar o clima escolar das instituições (THAPA et. al, 2013; VINHA et al., 2017; CADIAN e RESENDE, 2013a) e por isso elaboramos um bloco de questões para mensurar a percepção dos alunos sobre a justiça e a clareza das regras da escola que resultou no índice apresentado na tabela seguir.

Tabela 8: Resultado a análise fatorial e do teste de confiabilidade interna para o Índice de percepção dos alunos sobre as regras da escola.

\section{Índice de percepção dos alunos sobre as regras da escola}

Variável: Pense na escola em que você estuda. Marque qual é o seu nível de concordância com cada uma das Carga Fatorial afirmativas abaixo:

Na minha escola as regras são claras para todos os alunos. $\quad 0,732$

Na minha escola, as regras são justas. $\quad 0,880$ $\begin{array}{ll}\text { Na minha escola, as consequências para aqueles que } & 0,832 \\ \text { quebram as regras são justas. } & 0,86,6 \%\end{array}$

$\begin{array}{rr}\text { Variância explicada } & 66,6 \% \\ \text { KMO } & 0,638\end{array}$

Alpha de Cronbach $\quad 0,749$

Nota: Extraído pelo método de Análise de Componentes Principais (PCA) com rotação Varimax. Fonte: Questionário “Jovens e escolas: quais as relações?". Elaborado pela autora. 


\subsection{3.}

\section{Índice de participação discente}

Outro tema que desejávamos investigar em nossa pesquisa era a participação dos alunos, especialmente no ambiente escolar, desde a escuta das suas opiniões pelos demais atores escolares até a sua efetiva participação na elaboração e mudança nas regras da escola. Na tabela que se segue é possível visualizar as cargas fatoriais que compuseram o Índice de participação discente na vida escolar e $o$ Alpha de Cronbach da escala desenvolvida.

Tabela 9: Resultado a análise fatorial e do teste de confiabilidade interna para o Índice de participação discente na vida escolar.

\section{Índice de participação discente na vida escolar}

Variável: Indique a frequência com que estas coisas acontecem em sua escola:

Carga Fatorial

Os alunos são convidados a darem as suas opiniões sobre o que é melhor para a turma ou para a escola.

0,795

Os alunos sentem que as suas opiniões são ouvidas pelos professores, coordenadores e diretor (a).

Os alunos sentem que as suas opiniões são consideradas pelos professores, coordenador (a) e diretor (a).

Os alunos participam da elaboração e da mudança das regras da escola.

$\begin{array}{rr}\text { Variância explicada } & 67,2 \% \\ \text { KMO } & 0,768\end{array}$

Alpha de Cronbach

0,832

Nota: Extraído pelo método de Análise de Componentes Principais (PCA) com rotação Varimax. Fonte: Questionário “Jovens e escolas: quais as relações?”. Elaborado pela autora.

Inicialmente também pensávamos que seria interessante ampliar a ideia de participação discente para abranger outras esferas da vida social e incluímos um item acerca da participação deles em atividades extraescolares (como em ações sociais, ONGs, projetos sociais), mas como foi apenas um item, sua validação não foi possível e decidimos por analisar a questão apenas pela distribuição percentual das respostas entre instituições públicas e privadas. Futuramente, a construção de mais itens que possibilitem a criação de um índice de participação extraescolar dos alunos poderá ser importante para novas análises, inclusive para cotejar com o índice de participação discente no espaço escolar. 


\subsection{4. \\ Índices de autoeficácia dos jovens}

Um bloco de questões presente no questionário foi desenvolvido com o objetivo de mensurar o nível de autoeficácia dos alunos para realizar determinadas tarefas dentro e fora da escola. A análise fatorial realizada indicou a criação de dois índices, o primeiro que envolveu itens sobre a capacidade de "concluir o Ensino Médio", "ingressar no Ensino superior”, "obter bons resultados nas avaliações” e "conseguir um bom emprego no futuro", que denominamos de Índice de autoeficácia acadêmica, e o segundo que envolveu itens que avaliaram o quanto os alunos se sentiam capazes de "ajudar os colegas quando estão com dificuldade", "contribuir com a harmonia da sala" e "pensar em soluções para problemas que a escola esteja enfrentando", que denominamos de Índice de autoeficácia para cooperação escolar. A criação dos dois índices distintos nos obrigou a refazer as análises fatoriais com o intuito de buscar a confirmação do $\mathrm{KMO}$, Alpha de Cronbach e variância explicada para cada um dos dois índices, mais especificamente. Nas tabelas que se seguem é possível consultar a carga fatorial dos itens pertencentes a cada um dos índices, o KMO e o Alpha de Cronbach das escalas.

Tabela 10: Resultado a análise fatorial e do teste de confiabilidade interna para o Índice de autoeficácia acadêmica dos alunos.

\section{Índice de autoeficácia acadêmica}

Variável: Indique em que medida você se sente capaz de:

Carga Fatorial

Concluir o ensino médio.

0,883

Ingressar no ensino superior.

0,919

Obter bons resultados nas avaliações.

0,757

Conseguir um bom emprego no futuro.

0,787

$\begin{array}{rr}\text { Variância explicada } & 72,2 \% \\ \text { KMO } & 0,769\end{array}$

Alpha de Cronbach

0,869

Nota: Extraído pelo método de Análise de Componentes Principais (PCA) com rotação Varimax.

Fonte: Questionário “Jovens e escolas: quais as relações?”. Elaborado pela autora. 
Tabela 11: Resultado a análise fatorial e do teste de confiabilidade interna para o Índice de autoeficácia para cooperação escolar.

Índice de autoeficácia para cooperação escolar

Variável: Indique em que medida você se sente capaz de: Carga Fatorial

Ajudar os colegas quando estão com dificuldade em algum $\quad 0,708$ conteúdo.

$\begin{array}{ll}\text { Contribuir com a harmonia da sala. } & 0,806\end{array}$

Pensar em soluções para problemas que estejam acontecendo $\quad 0,785$ na escola.

Variância explicada $\quad 58,9 \%$

KMO $\quad 0,652$

Alpha de Cronbach

0 ,

Nota: Extraído pelo método de Análise de Componentes Principais (PCA) com rotação Varimax. Fonte: Questionário “Jovens e escolas: quais as relações?”. Elaborado pela autora.

Pesquisas anteriores sobre autoeficácia de estudantes (AZZI, GUERREIROCASANOVA e DANTAS, 2010; LEAL et al., 2015; AGUILERA, 2013), indicaram que tarefas como "ajudar os colegas quando estão com dificuldades", "contribuir com a harmonia da sala" e "pensar em soluções para problemas que estejam acontecendo na escola" em conjunto com "obter bons resultados nas avaliações" e "concluir o Ensino Médio" mediariam a autoeficácia acadêmica dos alunos. Por outro lado, a literatura citada indicava também que "conseguir um bom emprego no futuro" e "ingressar no ensino superior" seriam itens que mediriam a autoeficácia no desenvolvimento de carreira dos jovens. No caso do nosso estudo, essa tendência não se confirmou: os itens relativos ao desenvolvimento de carreira se mostraram correlacionados com a autoeficácia acadêmica, enquanto os referidos a crença na capacidade de cooperação no ambiente escolar compuseram um novo índice que denominamos de autoeficácia para cooperação.

Frente a isso, podemos levantar algumas hipóteses. Primeiramente, no que se refere aos itens criados para mensurar a percepção dos alunos sobre sua capacidade de ajudar os colegas e contribuir com a turma e com a escola podem ter sido interpretados como associados a valores e princípios éticos e não propriamente a cooperação acadêmica nas situações de aprendizagem. É possível ainda que a inexistência de colaboração presencial em razão do ensino remoto na pandemia tenha reforçado essa interpretação.

Por fim, na aferição da confiabilidade dos índices através do Alpha de Cronbach, o Índice de autoeficácia acadêmica obteve o alpha de 0,869, apontando 
uma alta confiabilidade da medida, enquanto o índice de autoeficácia para cooperação escolar obteve o alpha de apenas 0,652 , valor abaixo do esperado que mostra pouca confiabilidade do instrumento nesta medida. $\mathrm{O}$ fato de parte dos alunos estarem distantes da escola e do convívio com os amigos no momento da aplicação do questionário pode ter enviesado as respostas e definido este resultado. Levando em conta essas análises, optamos por considerar apenas o Índice de autoeficácia acadêmica para a análise exploratória dos resultados apresentada no próximo capítulo deste trabalho. 
6.

\section{O que dizem os jovens sobre as suas escolas}

Neste capítulo apresentamos algumas análises exploratórias dos resultados obtidos através da aplicação dos questionários para os jovens alunos das quatro escolas participantes da pesquisa. Primeiramente, apresentaremos o perfil dos jovens respondentes e, em seguida, serão apresentadas suas percepções sobre os principais temas do questionário: mobilização em relação à escola, mobilização em relação ao saber, clima das instituições, participação discente e autoeficácia. Como já mencionado, esta pesquisa foi realizada em meio à pandemia da Covid-19, em um ano atípico em que os alunos passaram grande parte do ano letivo afastado de suas escolas. Por esse motivo, no momento de aplicação do questionário, explicamos aos alunos que eles deveriam responder ao questionário considerando todo o tempo que estiveram matriculados naquela escola e não apenas o ano de 2020. Dessa forma buscamos coletar uma visão dos jovens sobre suas respectivas escolas menos carregada pelo contexto atípico da pandemia.

Como um dos nossos objetivos foi analisar como se dá a relação entre os jovens e diferentes espaços escolares, faremos uma análise dos aspectos mencionados acima priorizando a categorização de escolas públicas e privadas. No primeiro recorte estarão as duas escolas privadas de São Luís (MA) e uma do Rio de Janeiro, e no segundo recorte as duas escolas públicas de São Luís (MA). Ainda é importante destacar que, devido ao pequeno número de respostas e escolas, nossa análise é apenas exploratória e não possibilita fazer generalizações. Além disso, nas duas escolas públicas o número de respondentes foi menos da metade do total de alunos do $9^{\circ}$ ano matriculados nas instituições e não houve qualquer seleção de amostra, sendo a decisão por participar ou não da pesquisa tomada pelos próprios alunos. Isso significa que, em ambas as escolas, não podemos nem mesmo afirmar que os respondentes são uma amostra representativa dos alunos do $9^{\circ}$ ano de cada escola. Dessa forma, a análise exploratória dos resultados realizada busca apenas identificar as características dos alunos presentes em cada tipo de instituição escolar e suas percepções sobre a escola que estudam, para, eventualmente, sugerir questões para estudos posteriores. 


\section{1. \\ Perfil dos participantes}

Nesta seção apresentaremos o perfil dos 224 jovens participantes da pesquisa do ponto de vista sociodemográfico, trabalho e uso do tempo, trajetória escolar pretendida e vivida, participação social e hábitos de leitura. Como já assinalado, as análises serão feitas por dependência administrativa (pública ou particular) e pelo total da amostra. Infelizmente, devido ao baixo retorno das escolas públicas, o número de alunos participantes de cada um dos tipos de instituição é bem discrepante: sendo 184 estudantes de escolas privadas e 40 de escolas públicas.

\subsection{1. Indicadores sociais e econômicos dos jovens pesquisados}

Nesta seção apresentamos o perfil dos jovens pesquisados considerando suas condições socioeconômicas, sexo, cor/raça, escolaridade mãe e situação de trabalho. A relevância desta descrição se justifica pela extensa literatura que aponta como determinadas características sociais influenciam na trajetória escolar dos jovens e, portanto, sua relação com a escola. Estudos como os desenvolvidos por Barbosa (2009) e Alves, Soares e Xavier (2016) mostram a influência das condições socioeconômicas na trajetória escolar dos jovens e ressaltam que alunos pobres, negros e com mães com baixa escolaridade vivenciam em geral mais desvantagens no decorrer da trajetória escolar. Assim, o perfil da juventude que frequenta os dois tipos de instituições, públicas e privadas, fornece elementos importantes para compreender suas percepções sobre suas escolas.

Em relação ao sexo dos participantes, como aponta o gráfico apresentado abaixo, a maioria $(61,2 \%)$ dos nossos respondentes são do sexo feminino. Nas instituições públicas a diferença entre os sexos é ainda maior, sendo $70 \%$ de respondentes do sexo feminino e $30 \%$ do sexo masculino. O gráfico que se segue abaixo mostra a distribuição percentual de meninos e meninas que participaram da nossa pesquisa. 
Gráfico 4 - Sexo dos jovens participantes

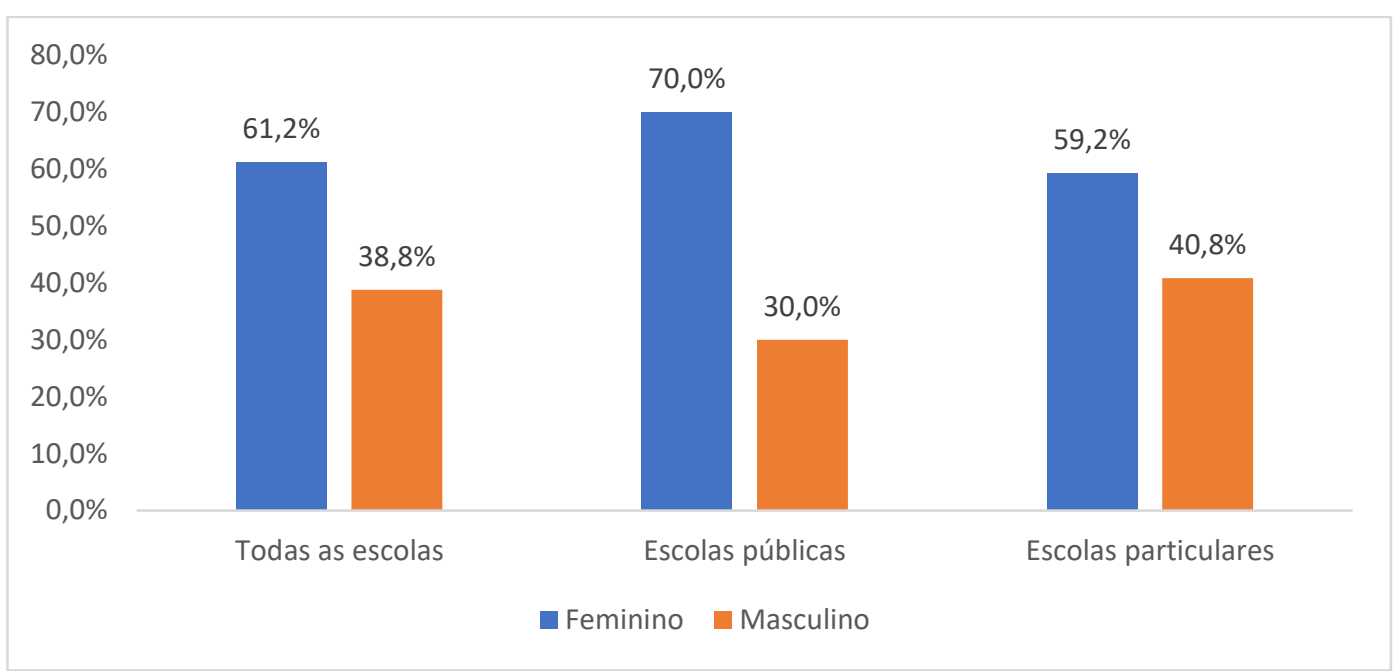

Fonte: Questionário “Jovens e escolas: quais as relações?”. Elaboração da autora.

No que se refere à cor/raça dos jovens participantes da pesquisa, o Gráfico 2 apresentado a seguir aponta que, nas escolas privadas, há um quantitativo superior de alunos brancos $(70,1 \%)$, enquanto nas escolas públicas presentes em nossa pesquisa há um predomínio de alunos que se auto declaram pardos $(42,5 \%)$, pretos $(17,5 \%)$ ou que preferem não declarar qual a sua cor ou raça $(17,5 \%)$. O quantitativo superior de alunos pardos e negros nas escolas públicas já era esperado, tendo em vista as desigualdades sociais e econômicas que atravessam o nosso país. No Brasil, o recorte cor/raça está muito vinculado ao recorte da renda, sendo assim, os alunos pardos e negros estão mais presentes nas instituições públicas de ensino, enquanto os brancos ocupam a maior parte das vagas nas escolas privadas (INEP, 2019). 
Gráfico 5 - Cor/raça dos jovens participantes

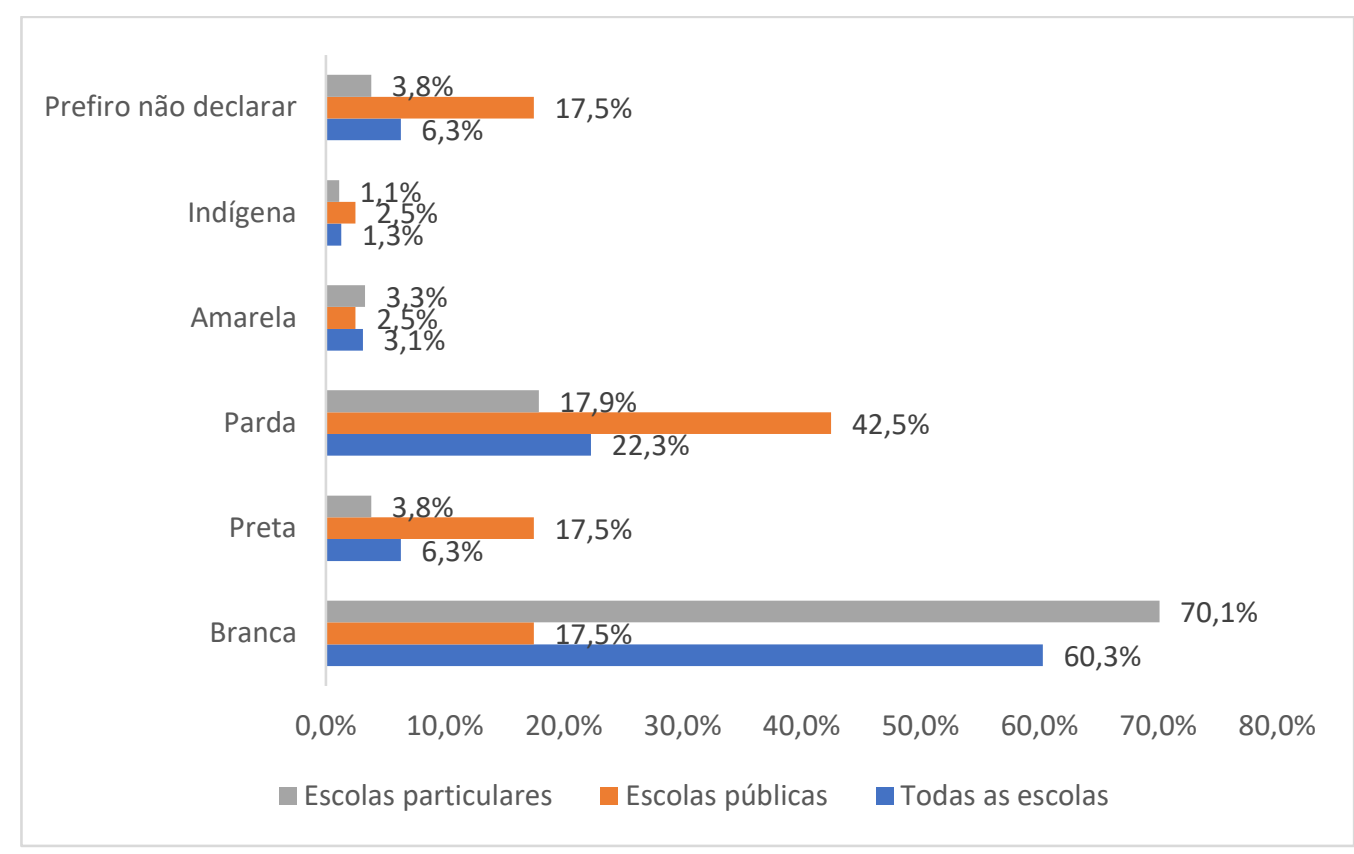

Fonte: Questionário “Jovens e escolas: quais as relações?”. Elaboração da autora.

A diferença de perfil dos alunos que frequentam as escolas públicas e privadas também se confirma pela diferença de escolaridade das mães dos alunos em cada caso. No campo das ciências sociais, particularmente no Brasil, a escolaridade dos pais é um importante marcador socioeconômico, pois expressa em larga medida os recursos culturais das famílias e seu acesso a diferentes empregos. Diversos estudos apontam que a trajetória escolar da família pode influenciar de diferentes maneiras a relação que o jovem estabelece com a escola (BARBOSA, 2009; CARRANO, MARINHO e OLIVEIRA, 2015). A baixa escolaridade dos pais pode ser considerada como uma desvantagem social e cultural que se transforma em desvantagem educacional pelo fato dos filhos não possuírem, desde o ambiente familiar, o capital cultural que é valorizado pela escola (BOURDIEU; PASSERON, 2014) ou que impulsiona a continuidade na trajetória escolar dos filhos em direção a uma mudança na condição social e econômica da família (DAYRELL; JESUS, 2015).

Apesar do nosso instrumento conter itens que informam sobre a escolaridade da mãe e do pai, decidimos apresentar nesta seção apenas a escolaridade da mãe, tendo em vista que a literatura indica que ela está mais fortemente associada à trajetória escolar dos filhos (LONGO e VIEIRA, 2017). Entre os respondentes, o percentual de mães de alunos na rede privada que completaram o Ensino Superior 
é de quase 90 pontos percentuais mais alta que entre as mães dos jovens das escolas públicas. Neste último caso, a maioria das mães (55\%) apenas completou o Ensino Médio e 17,5\% dos jovens dessas escolas não sabiam o nível de escolaridade da mãe. Esse dado poderia indicar que o tema da escolarização possivelmente é pouco presente no ambiente familiar.

Gráfico 6 - Escolaridade das mães dos jovens participantes.

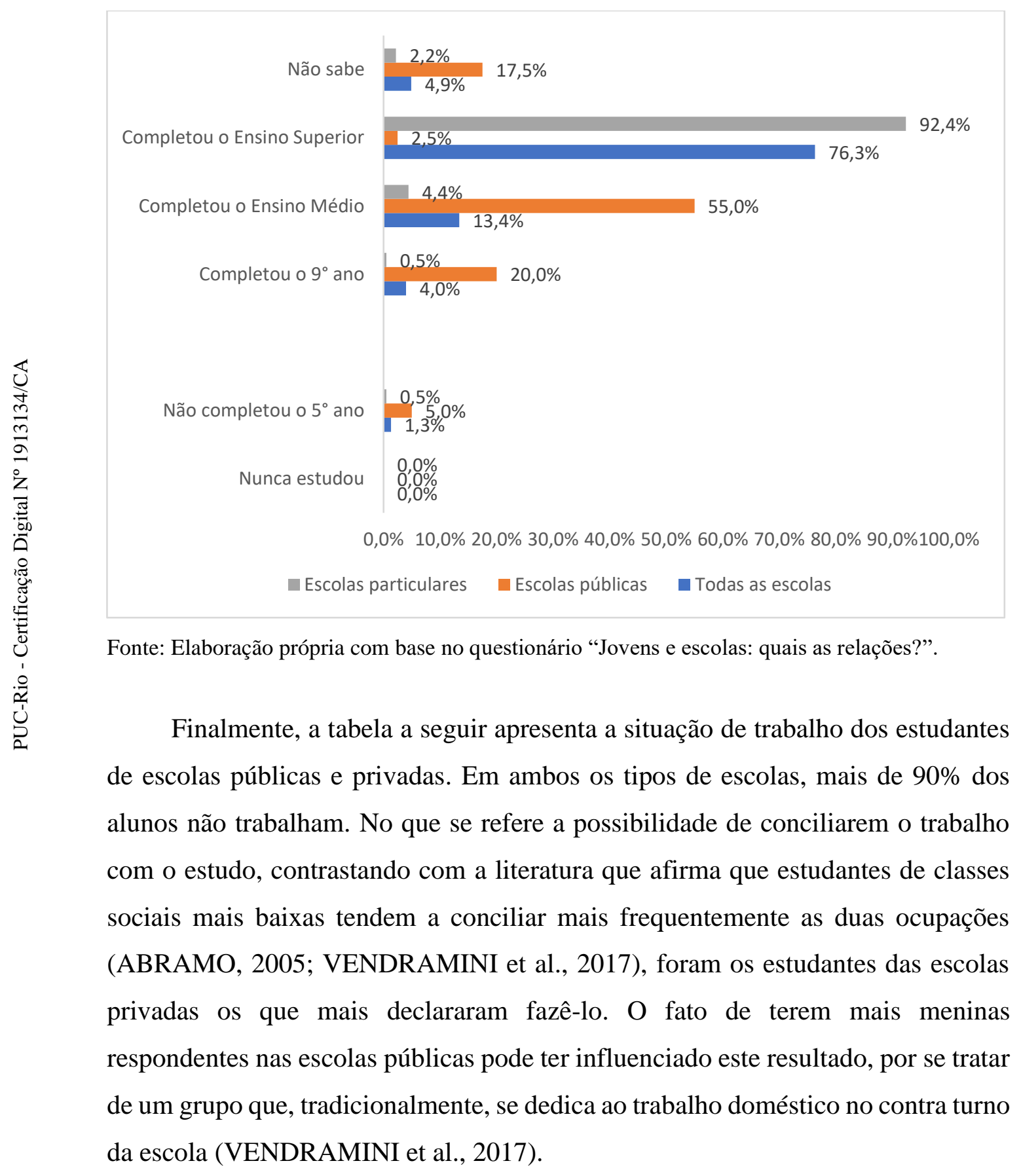


Gráfico 7 - Situação de trabalho dos jovens participantes.

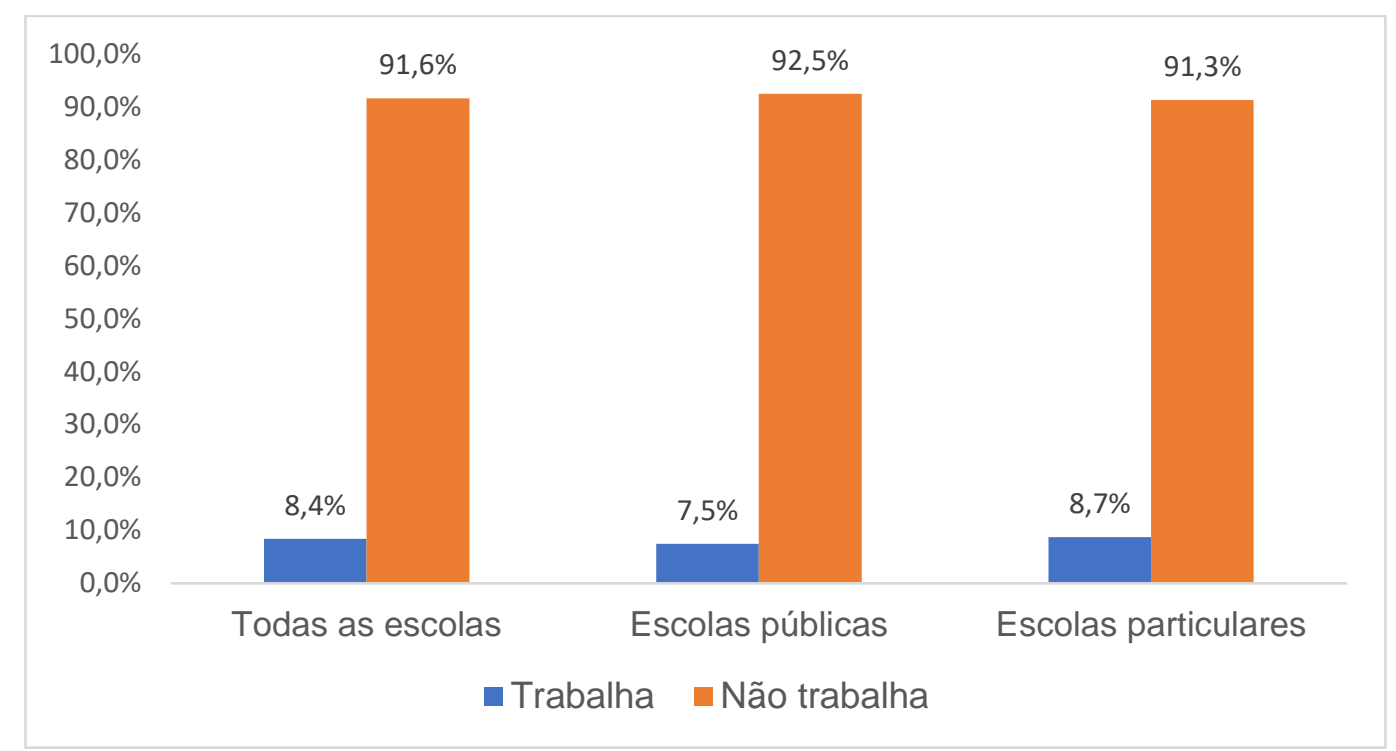

Fonte: Elaboração própria com base no questionário “Jovens e escolas: quais as relações?”.

Considerando os alunos de escolas públicas e privadas, os dados coletados mostram que a maioria dos jovens presentes em nossa amostra são do sexo feminino $(61,5 \%)$, se autodeclaram brancos $(60,3 \%)$, tem mães com ensino superior completo $(76,3 \%)$ e não trabalham $(91,6 \%)$. Cabe ressaltar, no entanto, como mostram os gráficos 2 e 3, que os resultados relativos à cor/raça e a escolaridade da mãe se explicam por termos conseguido acessar um número muito superior de alunos oriundos de escolas privadas.

\subsection{2.}

\section{Os jovens e as suas trajetórias escolares}

O nosso instrumento de pesquisa também buscou aferir sobre a trajetória escolar dos jovens, mais especificamente, se já haviam sido reprovados, em que momento entraram na escola, se tinham passado algum tempo sem frequentar a escola e voltaram a se matricular, seus planos para o futuro. Os gráficos apresentados a seguir mostram os resultados da análise. 
Gráfico 8 - Início da escolarização dos jovens participantes

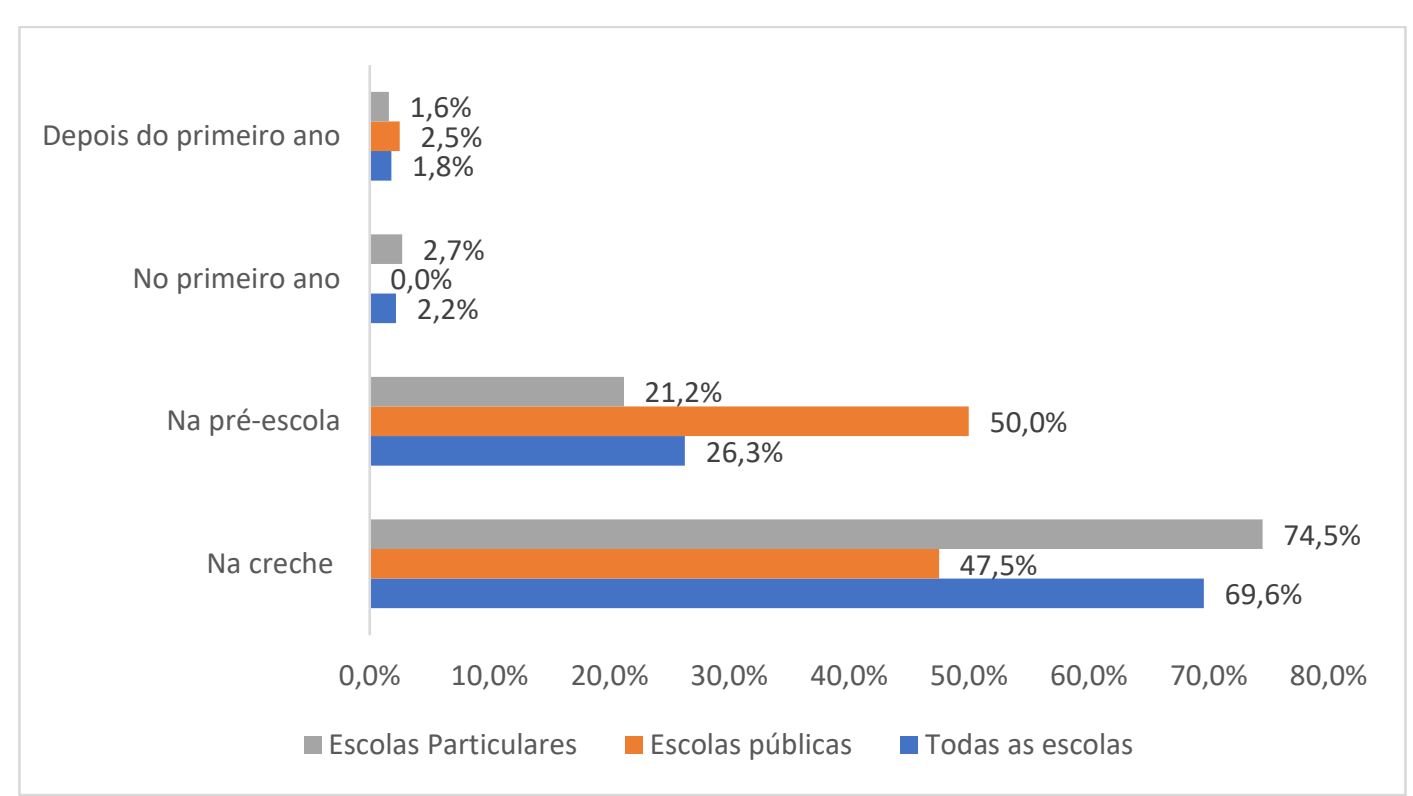

Fonte: Elaboração própria com base no questionário “Jovens e escolas: quais as relações?”.

A maioria $(69,6 \%)$ dos jovens pesquisados iniciaram a sua escolarização ainda na creche, no entanto, o contraste entre alunos das instituições privadas $(74,5 \%)$ e os que frequentam as públicas $(47,5 \%)$ é muito expressivo. Há inúmeras pesquisas que mostram que a frequência à pré-escola aumenta muito as chances de uma escolarização posterior bem-sucedida (CURI e MENEZES-FILHO, 2009), dessa forma, o fato de menos da metade dos alunos das escolas públicas terem frequentado a pré-escola pode indicar uma desvantagem precoce na escolarização dos jovens das escolas públicas em relação aos jovens das escolas privadas.

Desde que entraram na escola, a maioria dos jovens (96\%) não ficou algum tempo sem estudar, porém, mais uma vez, o percentual daqueles que o fez foi maior nas escolas públicas do que nas privadas (12,5\% e 2,2\%, respectivamente), como aponta o gráfico que se segue. 
Gráfico 9 - Pausa nos estudos pelos jovens participantes

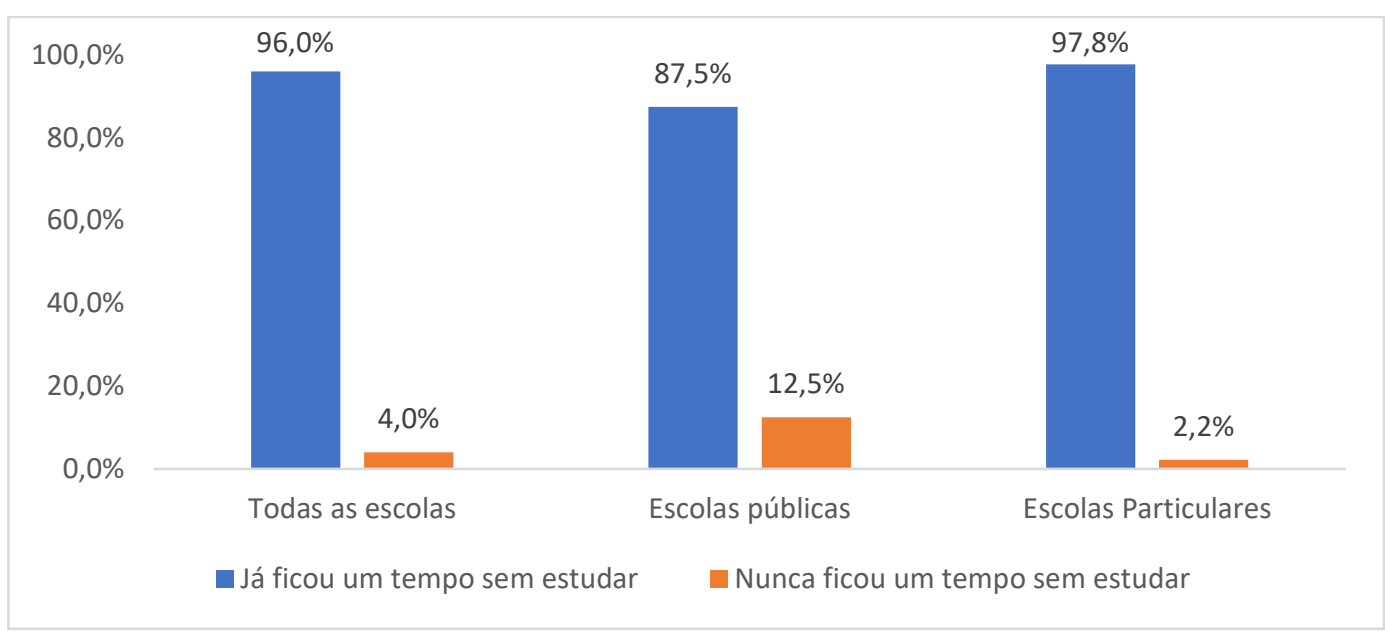

Fonte: Elaboração própria com base no questionário “Jovens e escolas: quais as relações?”.

Por fim, no que se refere à trajetória escolar vivida, embora a maioria dos jovens $(97,3 \%)$ da nossa amostra ter declarado que nunca foi reprovada, quando comparamos as dependências administrativas, o percentual de jovens que já reprovaram nas instituições públicas $(12,5 \%)$ é quase dez vezes superior ao das instituições privadas $(1,6 \%)$. Os dados educacionais nacionais mostram uma tendência similar a encontrada em nosso estudo, com maior número de reprovações na rede pública em comparação com a rede privada de ensino (INEP, 2019).

\section{Gráfico 10 - Histórico de reprovação dos jovens pesquisados}

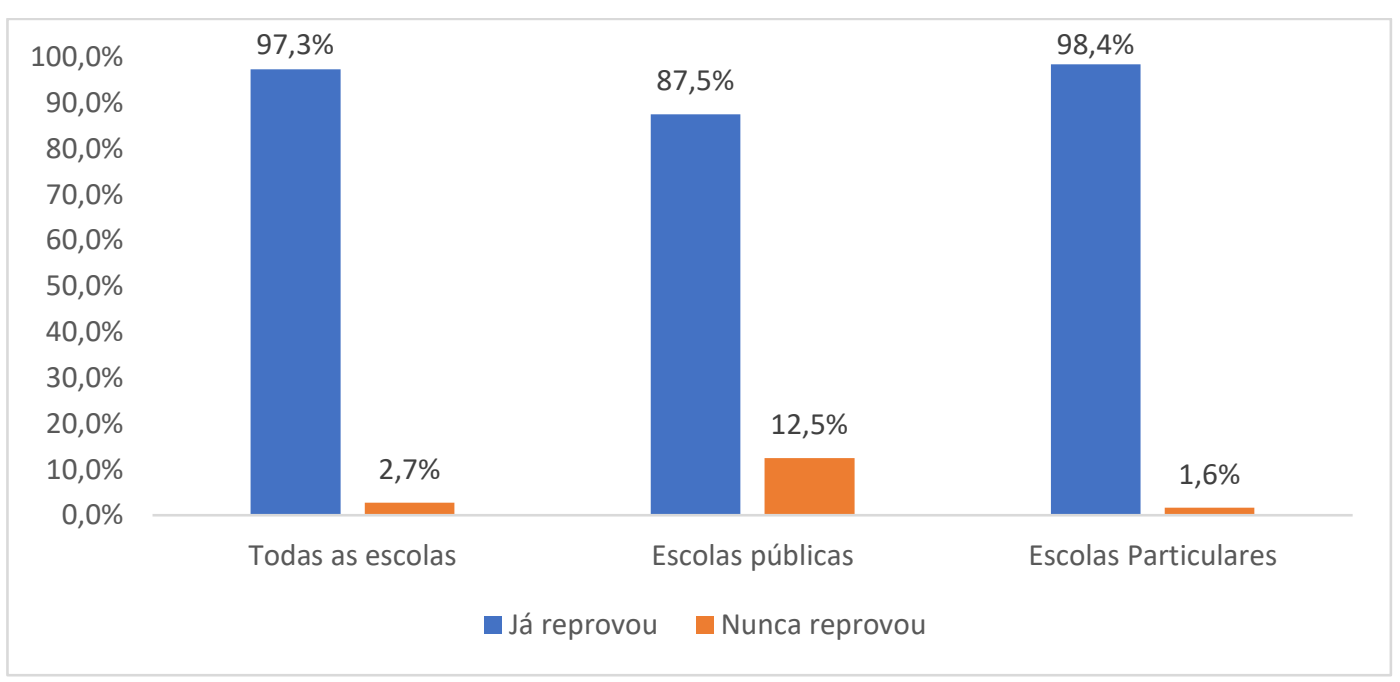

Fonte: Elaboração própria com base no questionário “Jovens e escolas: quais as relações?”.

Outras perguntas presentes em nosso instrumento buscaram aferir o que os jovens pretendem fazer após o nono ano e se eles se imaginavam cursando o Ensino 
Superior em cinco anos. No que se refere aos planos após o término do Ensino Fundamental, considerando a amostra total, a maioria dos alunos afirmou pretender continuar apenas estudando (58\%), no entanto, quando analisado por dependência administrativa, esse número é superior nas escolas privadas em relação às escolas públicas $(64,1 \%$ e $30 \%$, respectivamente). Nas escolas públicas, a maioria dos alunos declarou que pretende estudar e trabalhar simultaneamente $(55 \%)$, como mostra o gráfico a seguir. Esse resultado também corrobora com a literatura sobre juventude e trabalho e aponta a centralidade que o trabalho ainda possui na vida dos jovens brasileiros, em especial para aqueles que pertencem às camadas mais populares da sociedade e que geralmente precisam se dividir entre o estudo e o trabalho a partir de um determinado período da vida (GUIMARÃES, 2005; CARRANO; MARINHO; DE OLIVEIRA, 2015; ABRAMO, 2016).

\section{Gráfico 11 - O que os jovens pretendem fazer após terminar $09^{\circ}$ ano}

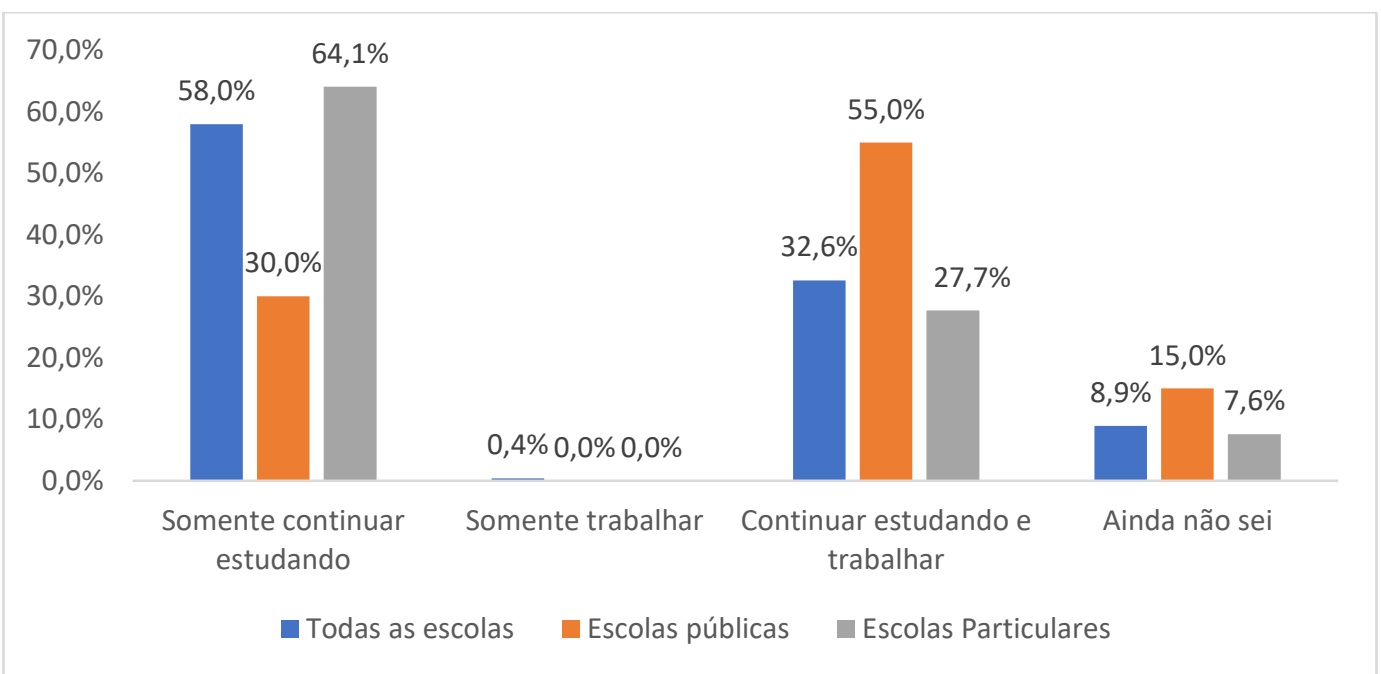

Fonte: Elaboração própria com base no questionário “Jovens e escolas: quais as relações?”.

Quando perguntado aos alunos se eles se imaginavam cursando o Ensino Superior em 5 anos, a grande maioria dos jovens respondeu que "sim" tanto nas instituições públicas $(95 \%)$ como nas privadas $(94,6 \%)$. Essa diferença mínima entre as instituições mostra que, independentemente do tipo de escola que frequentam, os jovens presentes em nossa amostra pretendem dar continuidade aos seus estudos após o término da educação básica. Esse resultado vai ao encontro dos resultados da pesquisa desenvolvida por Alves et al. (2015) com uma amostra de 3.081 jovens de 11 a 24 anos localizados em diversas cidades do Brasil. Os autores 
apontaram que os jovens pesquisados tinham altas expectativas em relação a concluir o Ensino Médio e ingressar em na universidade. O estudo de Amparo et al. (2008) também corrobora estes achados e mostra o otimismo dos jovens estudantes de escolas públicas em relação ao ingresso no ensino superior. O gráfico que se segue mostra os resultados das expectativas dos jovens para cada tipo de instituição e da amostra total.

Gráfico 12 - O que os jovens da pesquisa se imaginam fazendo em 5 anos.

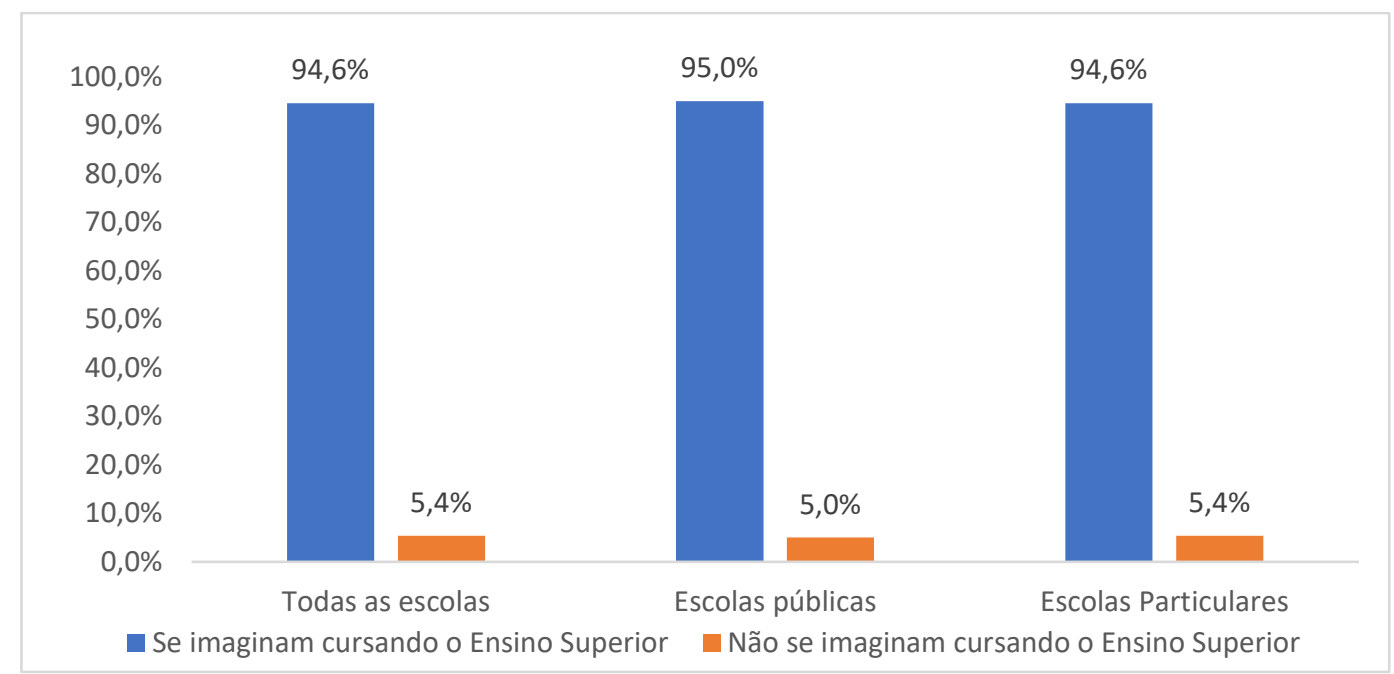

Fonte: Elaboração própria com base no questionário “Jovens e escolas: quais as relações?”.

Pode-se levantar a hipótese de que estes resultados podem estar relacionados às políticas de financiamento estudantil no ensino superior e às políticas de ação afirmativa, como a implementação da Lei de Cotas (BRASIL, 2012) nas universidades públicas desde 2012, que ampliaram as oportunidades de acesso de estudantes de classes populares no ensino superior, configurando um grande impulso para tornar a expectativa da continuidade nos estudos algo mais presente no horizonte dos possíveis para os jovens de diferentes camadas sociais.

\subsection{3.}

\section{Outros tipos de atividades realizadas pelos jovens}

Também indagamos sobre outras atividades que os jovens realizam além de estudar e trabalhar, como a frequência de leitura, afazeres de casa e a participação em ações e movimentos sociais. Todos esses aspectos são importantes para compreender o perfil dos jovens e as diferenças existentes entre o modo de ser e viver dos jovens alunos que frequentam os diferentes tipos de instituições escolares. 
Em primeiro lugar, sobre os hábitos de leitura dos jovens, como podemos ver no gráfico 10, considerando a amostra total, os percentuais estão bem distribuídos entre raramente $(27,7 \%)$, algumas vezes $(29,9 \%)$ e sempre $(30,4 \%)$. Nas escolas privadas, parece que há dois estilos de alunos preponderantes: aqueles que raramente leem $(30,4 \%)$ e os que sempre leem $(30,4)$. Nas escolas públicas, a maioria dos jovens leem algumas vezes (37,5\%). Na categoria "nunca leem” há um maior percentual de estudantes de escolas públicas do que de escolas privadas $(17,5 \%$ e $10,9 \%$, respectivamente).

\section{Gráfico 13 - Frequência que os jovens leem livros em geral}

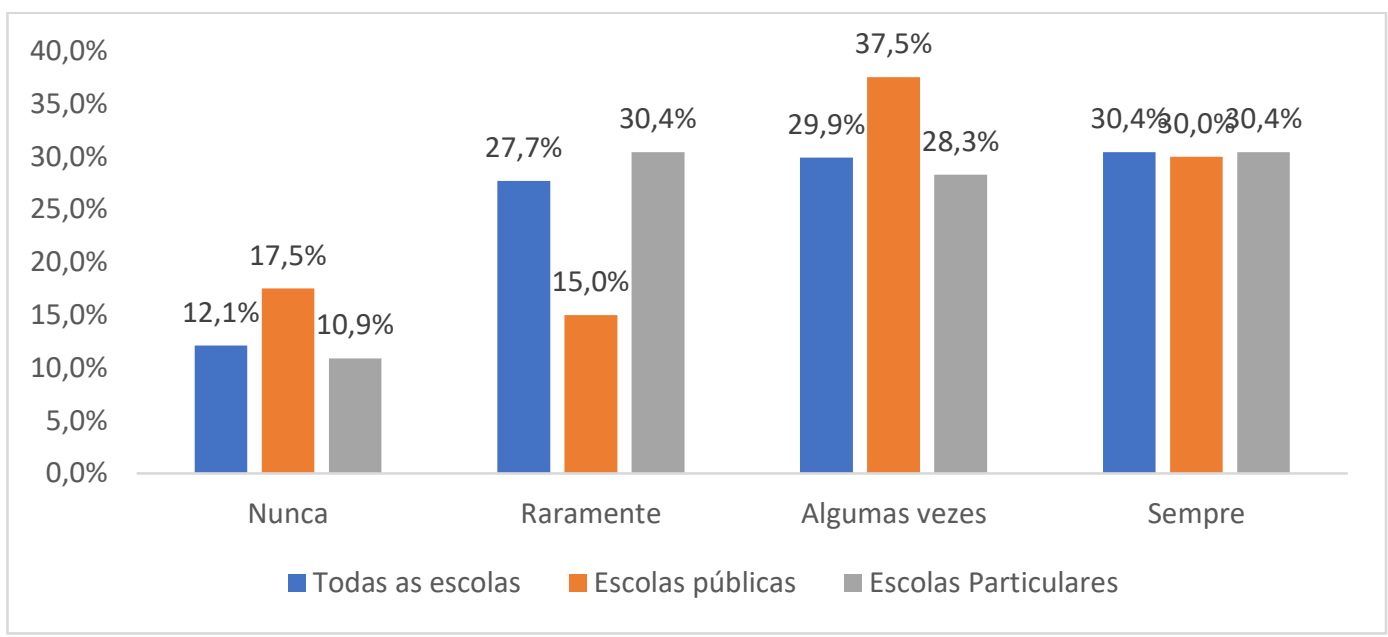

Fonte: Elaboração própria com base no questionário “Jovens e escolas: quais as relações?"

No que se refere a realização de tarefas domésticas em dias de aula, o gráfico apresentado a seguir revela que os estudantes de escolas públicas passam mais tempo realizando esse tipo de atividade do que os de escolas privadas. 
Gráfico 14 - Tempo de realização de tarefas doméstica pelos jovens

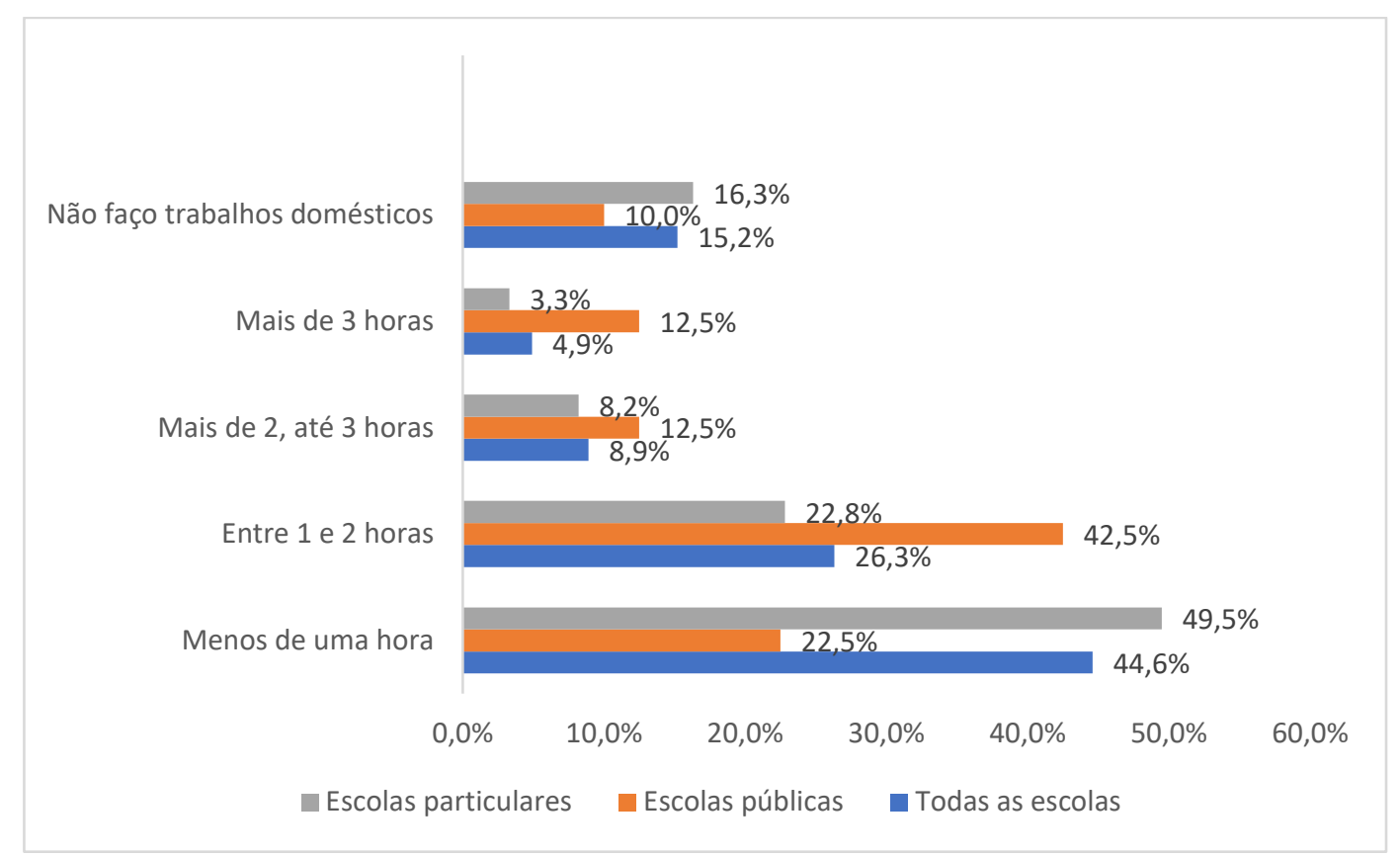

Fonte: Elaboração própria com base no questionário “Jovens e escolas: quais as relações?”.

A maioria $(43,5 \%)$ dos jovens de escolas públicas costumam a passar entre 1 e 2 horas fazendo atividades domésticas, enquanto a maioria dos jovens das escolas privadas $(49,5 \%)$ passam menos de 1 horas realizando esse tipo de atividade. Além disso, o número de estudantes que não realiza nenhum tipo de atividade doméstica é superior nas escolas privadas em comparação com as escolas públicas (16,3\% e $10 \%$, respectivamente).

A pesquisa desenvolvida por Vendramini et al. (2017) com 1.180 estudantes dos últimos anos do Ensino Fundamental e Médio moradores de uma comunidade localizada em Santa Catarina, mostrou que um dos desafios vivenciados pelos jovens era conciliar o estudo não apenas com o trabalho, mas também com os afazeres domésticos. Para esses alunos, depois do trabalho, o que mais atrapalhava nos estudos eram os afazeres domésticos que consumiam grande parte do seu tempo. Os dados da PNAD Contínua apresentados no capítulo 2 também corroboram esses achados e apontam que, principalmente para as mulheres, a necessidade de realizar afazeres domésticos tende a ser uma das principais motivações para não seguir estudando. Esses estudos revelam a complexidade da questão da realização de afazeres domésticos e como a discussão é permeada por recortes sociais e de gênero, que possuem uma centralidade no debate da juventude na atualidade. Cabe esclarecer que optamos por incluir a análise dos afazeres 
domésticos nesta seção porque seguimos a classificação do IBGE. Mesmo não sendo possível aprofundar esta discussão neste estudo, destacamos a relevância da problematização da ideia de trabalho doméstico como "inatividade econômica" e indica a necessidade de mudança de classificação para "trabalho não-remunerado"

Por fim, a participação dos jovens em coletivos, grêmios estudantis, organizações não governamentais (ONG), grupos religiosos ou outros movimentos sociais também foi aferida pela nossa pesquisa ${ }^{14}$. Dentre os 224 jovens escolas públicas e privadas que responderam ao questionário, apenas 87 não selecionaram nenhuma das opções. É importante destacar que no momento de aplicação do questionário surgiram algumas dúvidas sobre os itens presentes no questionário sobre participação: dois alunos perguntaram o que seria "coletivos" (Escola A Particular de São Luís) e outro aluno perguntou o que era "movimento estudantil" (Escola B - Particular de São Luís). Apesar dessas dúvidas não terem sido registradas por grande parte dos alunos, pensamos que estes itens ou sua formulação possivelmente mereçam ser revistos.

Os estudos recentes que falam sobre a participação social e protagonismo juvenil apontam a importância da participação social dos jovens para a compreensão do funcionamento da vida pública democrática (MARTINS; DAYRELL, 2013; DAYRELL; GOMES; LEÃO, 2010; CORTI; CORROCHANO; SILVA, 2016). Os resultados da nossa pesquisa apontaram que a atuação em coletivos é a forma mais usual de participação dos alunos tanto de escolas públicas como de privadas (63,6\% e 52,2\%, respectivamente). Esses resultados corroboram os achados de Carrano (2006) que a apontam a emergência dos coletivos juvenis uma nova forma de participação na esfera pública. De acordo com o autor, "os coletivos juvenis emprestam novos sentidos ao político e elaboram, com outras lógicas e sensibilidades, múltiplas formas e conteúdo de ação coletiva na experimentação da esfera pública" (CARRANO, 2006, p.4).

Por outro lado, os partidos políticos obtiveram a menor taxa de participação dos estudantes das escolas públicas $(13,6 \%)$ e privadas $(6,7 \%)$ participantes da pesquisa. Diversos estudos já vêm alertando para o afastamento da juventude dos espaços políticos tradicionais (KRISCHKE, 2005; DAYRELL, 2005; DAYRELL;

\footnotetext{
14 Pedimos para que os estudantes sinalizassem quais, dentre as atividades sociais citadas, eles participavam e, caso não fizessem parte de nenhum grupo ou ação social, poderiam deixar o item em branco.
} 
GOMES; LEÃO, 2010). Esse afastamento, de acordo com Dayrell, Gomes e Leão (2010) pode estar relacionado ao descrédito na atuação dos políticos e dos partidos crescentemente presentes na opinião pública brasileira. Krischeke (2005) argumenta também que novas formas de política, mais espontâneas e não convencionais, estão presentes no mundo todo, como é o caso dos coletivos e dos movimentos sociais.

Dayrell (2005) também considera que os jovens estão percebendo as ações voluntárias como um caminho mais possível de alcançar as suas demandas, seja pela flexibilidade em relação à disponibilidade do tempo e o grau de envolvimento exigido nessas atividades, ou pelo fato de produzir resultados imediatos e mais visíveis, como demanda o ritmo da juventude contemporânea. No que se refere aos jovens da nossa amostra, os estudantes das instituições privadas são mais ativos na participação em ONG do que os estudantes das instituições públicas. Esse resultado, no entanto, parece ter sido uma exceção, uma vez que nas demais formas de participação (coletivos, movimento estudantil, partido político e grupo religioso) os jovens das escolas públicas obtiveram os maiores percentuais, como pode visto no gráfico abaixo. Mais uma vez caberá investigar mais detidamente no futuro os significados e usos destes termos junto a diferentes grupos de jovens.

\section{Gráfico 15 - Tipos de participação social exercida pelos jovens}

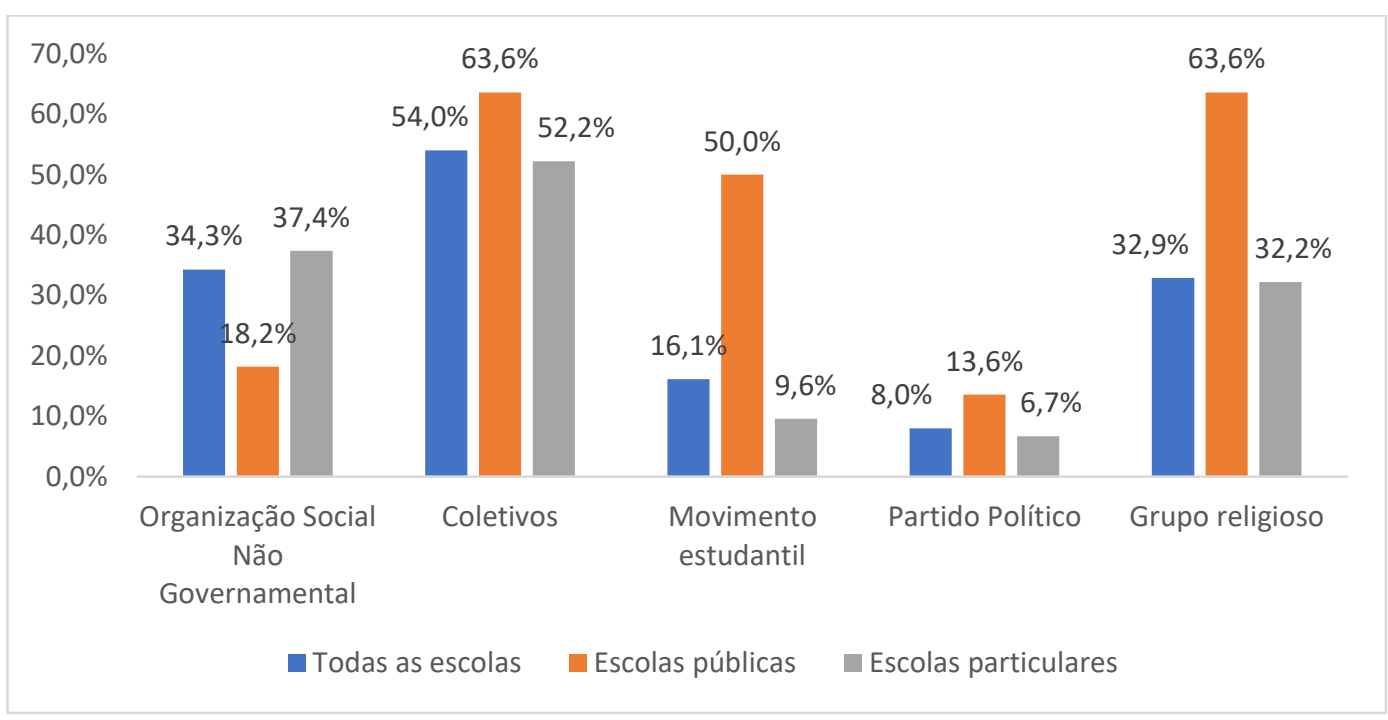

Fonte: Elaboração própria com base no questionário “Jovens e escolas: quais as relações?

O fato de os alunos de escolas públicas serem mais atuantes nas atividades sociais listadas no gráfico 12 vai de encontro aos obtidos em outro item do 
questionário que buscava aferir se as escolas incentivavam os alunos a participarem de ações sociais. Como mostra o gráfico 13 a seguir, mais de $90 \%$ dos jovens das escolas privadas afirmaram que "algumas vezes" e "frequentemente" são incentivados a participarem de ações sociais fora da escola, enquanto entre os alunos das escolas públicas esse percentual é de 45\%, embora, como já discutido, os alunos das escolas públicas tenham se mostrado mais atuantes nesse tipo de atividade em comparação com os das escolas privadas. Ou seja, a participação parece pouco influenciada pela escola pública.

Gráfico 16 - Frequência em que os alunos são incentivados a participarem de ações fora da escola (projetos sociais, trabalhos em ONG'S, movimentos sociais).

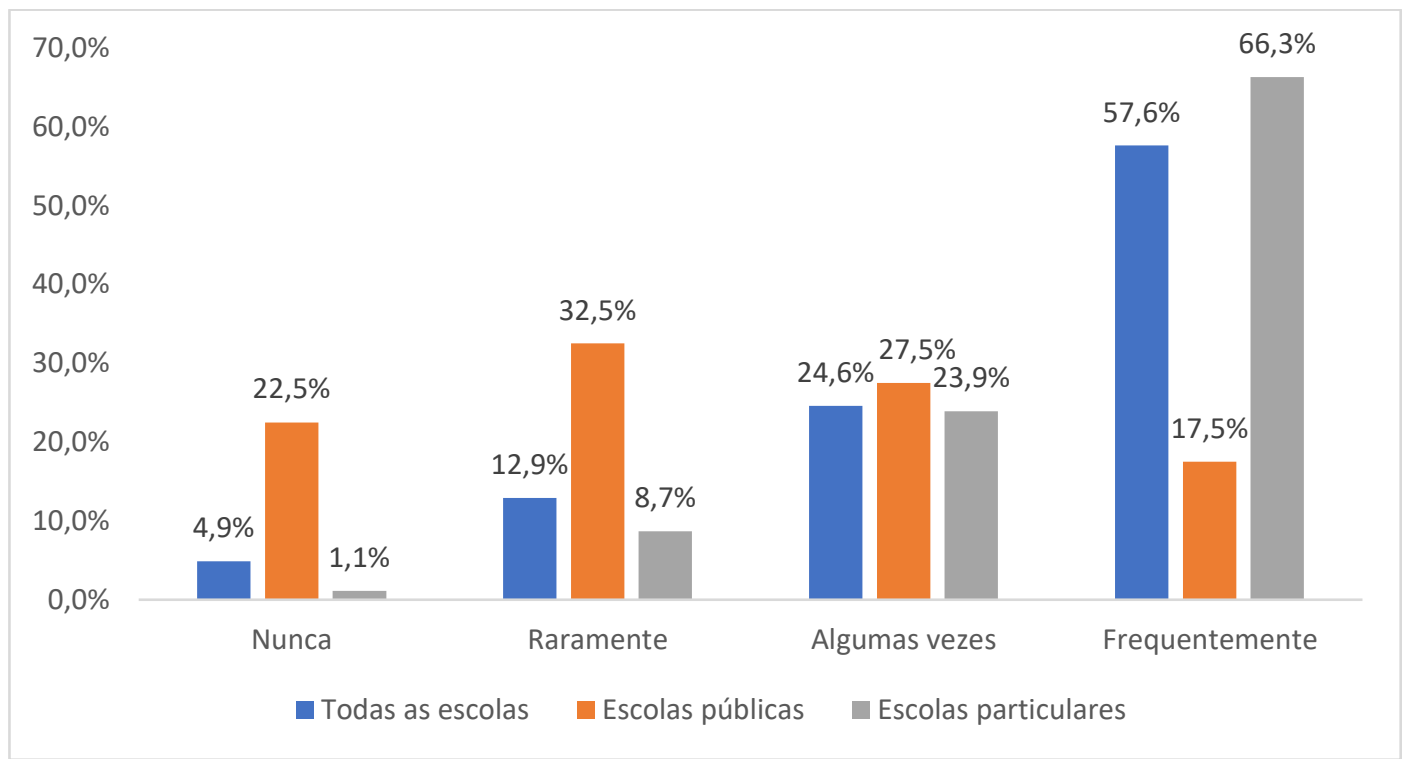

Fonte: Elaboração própria com base no questionário “Jovens e escolas: quais as relações?”.

Esse resultado contrata em certa medida com as conclusões de Dayrell, Gomes e Leão (2010) que apontam como um dos motivos da baixa participação social da juventude a falta de incentivo da escola para atuação dos jovens nesses espaços, indicando ser um tema que mereceria mais estudo.

Outro fato que nos chamou atenção foi a diferença entre a participação dos alunos de escolas públicas e privadas em grupos religiosos, em que os primeiros obtiveram um percentual consideravelmente superior $(63,6 \%$ e $32,2 \%$, respectivamente). A importância da religião para os jovens das classes sociais mais baixas foi discutida por Gomes (2007) que destacou como as igrejas podem ser um espaço especialmente atrativo nas periferias, em que faltam espaços e equipamentos 
públicos de lazer e de cultura que os jovens possam frequentar, dessa forma, as igrejas se tornam relevante um local de diversão e de socialização importante.

\section{2.}

\section{A mobilização dos alunos em relação à escola e a importância do que aprendem}

Nesta sessão analisaremos as respostas dos alunos acerca dos itens que buscavam compreender os motivos pelos quais os jovens vão à escola e a importância que eles dão para o que aprendem, por dependência administrativa. Como abordado no capítulo anterior, no que se refere à mobilização dos alunos em relação à escola, a análise fatorial indicou que os alunos pesquisados se mobilizavam para ir à escola por três motivos: por causa da aprendizagem, porque achavam importante para alcançar projetos futuros e para socializar com os colegas.

Para mensurar a mobilização dos jovens em relação à escola utilizamos as categorias "alta mobilização", "média mobilização" e "baixa mobilização". Essas categorias foram criadas a partir da divisão, em três partes, das pontuações obtidas pelos alunos na escala Likert que compunha o nosso questionário. Sendo assim, considerando que o nosso questionário utilizou a escala Likert de 4 pontos ( $1=$ discordo muito; $2=$ discordo; $3=$ concordo; 4 = concordo muito), calculamos a pontuação máxima e a pontuação mínima obtida pelos jovens participantes da nossa pesquisa em cada um dos índices criados e dividimos essas pontuações em três partes.

No caso do índice de mobilização para aprendizagem, consideramos que as notas entre 6,00 até 8,00 seriam consideradas "baixa mobilização", as notas entre 9,00 e 13,00 seriam consideradas "média mobilização" e as notas entre 14,00 a 16,00 seriam "alta mobilização". Fizemos esse procedimento com todos os outros índices que serão discutidos nessa seção (Índice de mobilização para projetos futuros e o Índice de socialização) mudando apenas a nota de corte das categorias "baixa", "alta e "média" de acordo com a nota mais baixa e mais alta obtida em cada um dos índices. As tabelas com os valores de corte de cada um dos índices se encontram no Apêndice B.

Voltando para a análise da mobilização dos alunos em relação à escola, a tabela apresentada a seguir mostra como os alunos de cada tipo de instituição (pública e privada) se mobilizam em relação à escola, ou seja, em que medida os 
motivos pelos quais eles vão à escola estão mais vinculados à aprendizagem que é adquirida nesse ambiente, ao alcance dos seus projetos futuros que dependem da escolarização ou à convivência/socialização com os amigos.

Tabela 12 - Mobilização dos jovens participantes em relação à escola

\begin{tabular}{ccccccc}
\hline & \multicolumn{2}{c}{$\begin{array}{c}\text { Mobilização para a } \\
\text { aprendizagem }\end{array}$} & \multicolumn{2}{c}{$\begin{array}{c}\text { Mobilização para } \\
\text { projetos futuros }\end{array}$} & \multicolumn{2}{c}{$\begin{array}{c}\text { Mobilização para a } \\
\text { socialização }\end{array}$} \\
\cline { 2 - 7 } & $\begin{array}{c}\text { Escolas } \\
\text { Públicas }\end{array}$ & $\begin{array}{l}\text { Escolas } \\
\text { Privadas }\end{array}$ & $\begin{array}{c}\text { Escolas } \\
\text { Públicas }\end{array}$ & $\begin{array}{c}\text { Escolas } \\
\text { Privadas }\end{array}$ & $\begin{array}{c}\text { Escolas } \\
\text { Públicas }\end{array}$ & $\begin{array}{c}\text { Escolas } \\
\text { Privadas }\end{array}$ \\
\cline { 2 - 7 } Baixa & $0 \%$ & $6 \%$ & $1 \%$ & $0 \%$ & $3,3 \%$ & $10,0 \%$ \\
\cline { 2 - 7 } Média & $70,0 \%$ & $72,3 \%$ & $42,4 \%$ & $25 \%$ & $66,6 \%$ & $75,5 \%$ \\
\cline { 2 - 7 } Alta & $30,0 \%$ & $21,7 \%$ & $56,5 \%$ & $75 \%$ & $30,4 \%$ & $12,5 \%$ \\
\hline
\end{tabular}

Fonte: Questionário “Jovens e escolas: quais as relações”. Elaboração própria.

Como mostra a tabela 12, a pesquisa apontou que os jovens das escolas públicas $(56,5 \%)$ e das escolas privadas $(75 \%)$ se sentem altamente mobilizados para ir à escola para alcançar seus objetivos no futuro, como ingressar no ensino superior, conseguir um trabalho futuramente e ter melhores condições de vida que os pais/responsáveis. Esse resultado corrobora com achados de Tomazetti et al. (2011), Dayrell, Reis e Leão (2011), Pereira e Lopes (2016) e Freitas, Batista e Melo (2017) que indicam forte tendência de os alunos enxergarem a escola como uma ponte para a realização de projetos futuros.

Sobre a mobilização para a socialização, ou seja, ir à escola para encontrar os amigos e porque gostam do intervalo e/ou recreio, o percentual de alunos que considera esse como um dos principais mobilizadores em relação à escola é maior nas instituições públicas $(30,4 \%)$ do que nas privadas (12,5\%). Outros autores como Santos, Nascimento e Menezes (2012), Dayrell e Jesus (2015) e Stoski e Gelbcke, 2016) já destacaram a importância da convivência no ambiente escolar, inclusive como um fator indispensável para que os alunos seguissem com suas trajetórias escolares. Em nossa pesquisa, esse aspecto pareceu ser mais importante para os alunos das escolas públicas do que para os das escolas privadas. Esse poderia ser um aspecto para futuro aprofundamento da pesquisa com amostras representativas de cada população. Caberia investigar, por exemplo, a menor valorização da socialização nas escolas privadas estaria relacionada com a pressão por desempenho, comum em escolas privadas que atendem a camadas médias e elites, como as investigadas nesta pesquisa. 
Por fim, no que se refere à mobilização em relação à aprendizagem, 30\% dos alunos das escolas públicas e 21,7\% dos alunos das escolas privadas possuem uma alta mobilização em relação à aprendizagem, indo à escola por interesse ou preocupação relacionados aos conteúdos ensinados ou porque se interessam por alguma disciplina ou professor. A grande maioria dos alunos (70\% e 72,3\%) se sentem apenas medianamente mobilizados em relação à aprendizagem, o que poderia apontar os gestores e docentes em geral sobre a necessidade de engajar mais os alunos em relação ao acesso ao conhecimento que a escolarização pode (ou deveria) significar.

A maior mobilização dos alunos das escolas públicas para aprendizagem em relação aos alunos das instituições privadas contrasta com os resultados encontrados por Freitas, Batista e Melo (2017). Estes autores apontaram que os alunos de grupos socioeconômicos mais altos por eles investigados relataram com mais frequência que estavam na escola porque gostavam de estudar do que os alunos de grupos socioeconômicos menos favorecidos. Contudo, é provável que esta discrepância esteja relacionada a grande diferença de número de respostas de escolas públicas e privadas obtidas pela nossa pesquisa e por um viés de seleção no caso dos alunos das escolas públicas no contexto da pandemia e da suspensão das atividades escolares presenciais. Ao lado disso, é possível que os alunos das escolas públicas que responderam ao nosso questionário possuíssem melhores condições socioeconômicas (inclusive o acesso à internet) ou mais interesse pela escola do que seus colegas de escola que não responderam ao questionário. Ambos os fatores podem ter interferido no resultado deste componente. Por fim, o baixo percentual de alunos com baixa mobilização para aprendizagem pode ser considerado um indício positivo sobre o papel que os saberes escolares têm na vida dos jovens pesquisados.

A questão em torno do sentido que os conteúdos aprendidos na escola possuem na vida dos jovens é discutida por autores como Dayrell e Jesus (2015), Ramos e Salva (2014) e Brenner e Carrano (2014). Considerando essa literatura, perguntamos aos jovens qual a importância do que eles aprendem na escola para os seguintes aspectos da sua vida: para o futuro profissional, para compreender a realidade do mundo, para fazer amigos, para o que faz no dia a dia, para acessar os conhecimentos e saberes produzidos pela ciência e para conviver melhor em 
sociedade. A tabela com os dados obtidos a partir dessa questão pode ser consultada no apêndice $\mathrm{C}$, ao final do trabalho.

Os jovens respondentes da nossa pesquisa, tanto das escolas públicas como das privadas, declararam acreditar que a maior importância do que aprendem na escola é para o seu futuro profissional: $90 \%$ dos alunos das escolas públicas e 72,5\% das privadas responderam que acham "muito importante" o que aprendem na escola para a sua futura profissão. Os alunos das escolas públicas acreditam que o que aprendem na escola tem pouca importância para as coisas que fazem no dia a dia. Os respondentes das escolas privadas, por sua vez, acreditam que o que aprendem na escola é menos importante para fazer amigos, seguido de "para as coisas que fazem no dia a dia". Esses resultados corroboram as discussões sobre o deslocamento do sentido da escola e da aprendizagem para o futuro discutido por Pereira e Lopes (2016) com base nos relatos dos jovens no estudo por eles desenvolvido que descreviam que os conteúdos escolares eram inúteis para o dia a dia e distantes do seu interesse.

Podemos concluir que a maior parte dos achados acerca da mobilização dos jovens participantes das pesquisas em relação à escola e sobre a importância que dão ao que aprendem confirmam os resultados dos estudos pré-existentes sobre juventude e escola. Quando comparamos os tipos de instituição em relação à mobilização, é possível perceber que os jovens pesquisados que são alunos das instituições públicas veem como principal motivo para irem à escola o alcance de objetivos no futuro, seguido da socialização e, por último, para a aprendizagem, ainda que a diferença entre os dois últimos tenha sido pouco significativa. Já os estudantes das escolas privadas, também veem a realização de projetos futuros como principal motivo para irem à escola, no entanto, a aprendizagem é um fator que mobiliza mais esses estudantes do que a socialização.

As reflexões já mencionadas de Bernard Charlot (1996) sobre como o investimento no estudo (a mobilização na escola) depende do sentido que o aluno dá ao fato de ir à escola (a mobilização em relação à escola) vão na mesma direção e sugere a reflexão sobre como essa mobilização em relação à escola deslocada para o futuro pode estar contribuindo para as relações estabelecidas entre os alunos e a escolas no Brasil. 


\section{3.}

\section{A percepção dos jovens sobre o clima escolar}

Nesta seção apresentamos a percepção dos jovens participantes da pesquisa sobre o clima das suas instituições, considerando as dimensões infraestrutura, relações interpessoais, ambiente acadêmico, segurança física e emocional, pertencimento e as regras da escola. Utilizando o mesmo processo descrito da seção 6.2, criamos as categorias "boa", "intermediária" e "ruim" para diagnosticar a percepção dos jovens participantes sobre o clima escolar do estabelecimento em que estudavam. Apenas na dimensão "Pertencimento" optamos por classificar em "alto pertencimento" "médio pertencimento" e "baixo pertencimento", por acreditarmos que ficaria mais condizente com nossas análises. Os valores de corte utilizados para a definição das medidas em cada uma das dimensões presentes no instrumento encontram-se no apêndice B.

\subsection{1.}

\section{A percepção dos jovens sobre a dimensão infraestrutura}

A infraestrutura é considerada por vários autores como uma importante dimensão para avaliar o clima das instituições escolares (COHEN et al., 2009; THAPA et al, 2013; VINHA et al., 2017). As pesquisas apontam que uma infraestrutura física adequada contribui para que os alunos se sintam bem dentro dos ambientes escolares e se dediquem mais aos estudos (THAPA et al, 2013). A dissertação de Simone Gomes de Melo (2017) apontou que as escolas com desempenho acima do esperado tinham a dimensão infraestrutura do clima escolar mais positiva que as escolas com desempenho abaixo do esperado.

No caso da nossa pesquisa, a infraestrutura foi avaliada através de um índice que contêm itens que medem a percepção dos alunos sobre o conforto, limpeza e preservação das salas de aula, a existência de uma biblioteca com livros variados na escola, a adequação dos espaços destinados ao intervalo e/ou recreio e se os alunos acreditavam que a escola oferecia um ambiente favorável para todos aprenderem.

A tabela 13 mostra que os alunos das escolas públicas e privadas percebiam o seu ambiente escolar de maneira distinta. Enquanto a maioria $(66,8 \%)$ dos alunos das escolas privadas avaliaram a infraestrutura da sua escola como boa e apenas $1,1 \%$ avaliou como ruim, nas escolas públicas apenas $5 \%$ acha que a sua instituição 
tem boas condições físicas e $15 \%$ a avalia como ruim. A maioria dos alunos das escolas públicas (80\%) acredita que a sua escola tem uma infraestrutura intermediária.

Tabela 13 - Percepção dos jovens sobre a infraestrutura da escola

\begin{tabular}{lcc}
\hline & Escolas Públicas & Escolas Privadas \\
\hline Ruim & $15 \%$ & $1,1 \%$ \\
\hline Intermediária & $80 \%$ & $32,1 \%$ \\
\hline Boa & $5 \%$ & $66,8 \%$ \\
\hline
\end{tabular}

Fonte: Questionário “Jovens e escolas: quais as relações?” Elaboração própria.

Considerando a importância da dimensão infraestrutura para a construção de um clima escolar positivo destacada por diversos autores, assim como os estudos sobre eficácia escolar desenvolvidos no Brasil que mostram como o ambiente físico e a existência de recursos no ambiente escolar pode impactar no desempenho dos alunos (ALBANEZ; FERREIRA; FRANCO, 2002; ANDRADE; LAROS, 2007), esses achados trazem indicativos importantes sobre a necessidade de refletirmos sobre as diferenças de recursos ofertados nas instituições do país.

\subsection{2.}

\section{A percepção dos jovens sobre as relações interpessoais do ambiente escolar}

Dentre as diferentes dimensões que compõem o clima escolar, a qualidade das interações entre os atores escolares é tratada na literatura como um elemento central para a construção de um clima escolar positivo (AGUERRE, 2004; COHEN et al., 2009; THAPA et al., 2013; BEAR et al., 2015; COELHO, 2019). Em nosso estudo, para facilitar a interpretação dos dados qualificamos a percepção dos alunos sobre as suas relações com os atores da escola em "boa/muito boa", "regular", "ruim/muito ruim" e "não tenho relação". Os resultados revelaram que, de uma forma geral, a maioria dos jovens das instituições públicas e privadas avaliam como "boa/muito boa" suas relações com os professores, diretor (a), a coordenação, os funcionários da escola, os colegas de turma e os outros alunos da escola, como mostram os gráficos a seguir. 
Gráfico 17 - Percepção dos jovens das escolas privadas sobre a qualidade das relações interpessoais

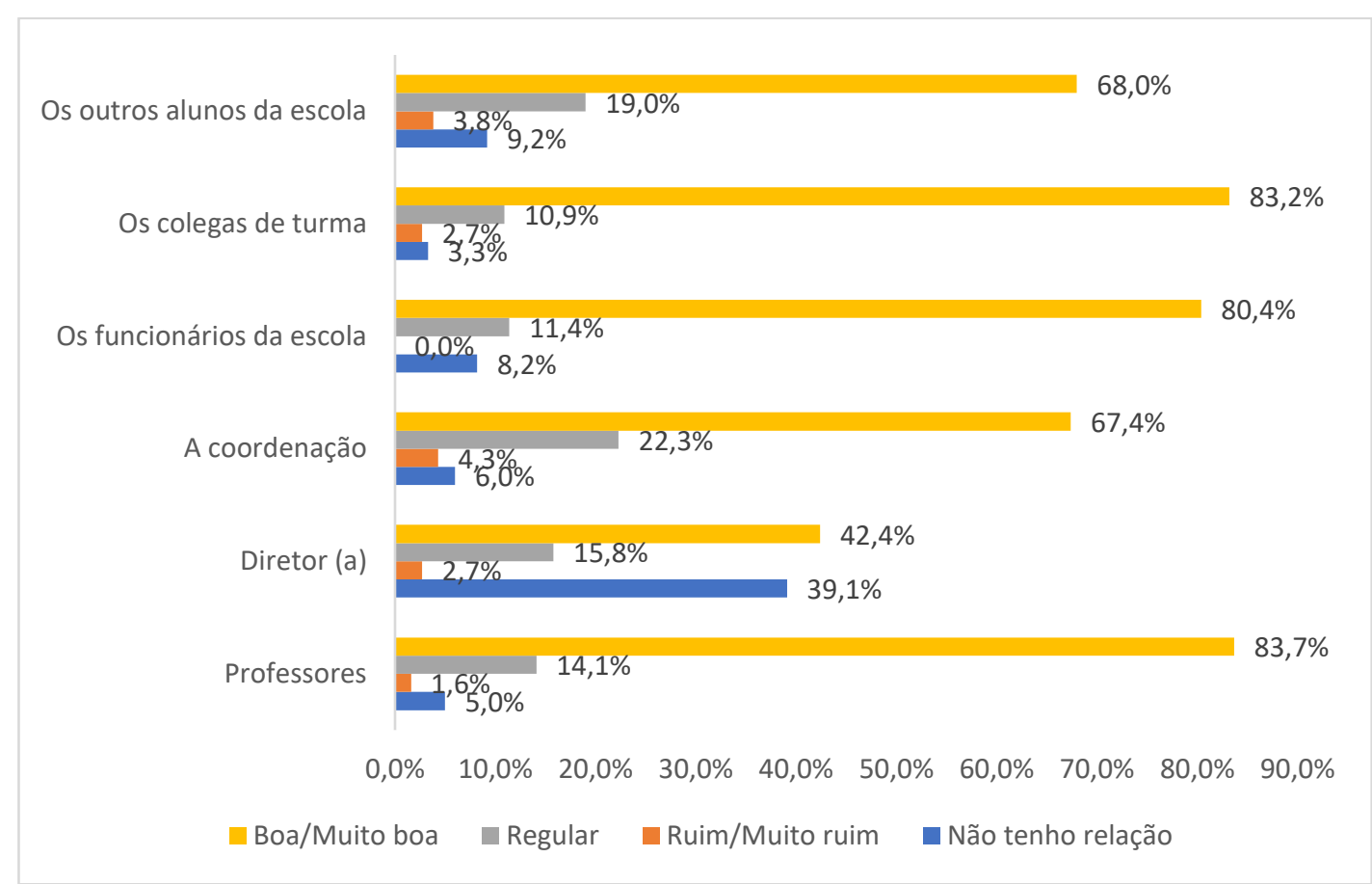

Fonte: Elaboração da autora com base no questionário "Jovens e escolas: quais as relações?"

Gráfico 18 - Percepção dos jovens das escolas públicas sobre a qualidade das relações interpessoais

Os outros alunos da escola

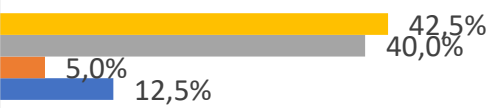

Os colegas de turma

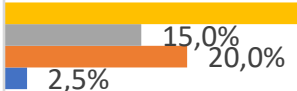

$77,5 \%$

Os funcionários da escola

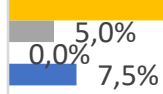

A coordenação

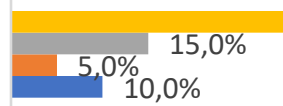

$70,0 \%$

Diretor (a)

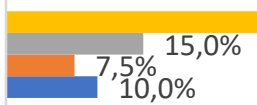

$67,5 \%$

Professores

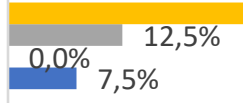

$80,0 \%$

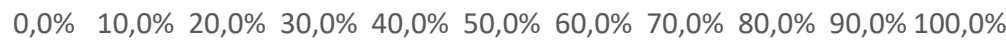

$$
\text { Boa/Muito boa } \square \text { Regular } \square \text { Ruim/Muito ruim } \square \text { Não tenho relação }
$$

Fonte: Elaboração da autora com base no questionário "Jovens e escolas: quais as relações?" 
Quando analisamos mais especificamente as diferenças entre os dois tipos de escola, podemos perceber que a maior diferença está na relação com o (a) diretor (a). Nas escolas privadas 39,1\% dos alunos afirmaram não ter relação com o diretor enquanto nas escolas públicas esse percentual foi de apenas $10 \%$ e a grande maioria $(67,5 \%)$ afirmou ter uma boa relação com o diretor. Quando voltamos para as características das instituições públicas e privadas apresentadas no capítulo 4 deste trabalho, podemos perceber que, nas escolas privadas, há um maior número de pessoas que compõem a equipe gestora da escola, como coordenadores, tutores, coordenadores nacionais e internacionais, enquanto nas escolas públicas a figura do diretor é mais central, o que tende a trazer mais proximidade com os alunos. Essa diferença de composição da equipe gestora pode explicar o fato de os alunos das escolas públicas terem um maior contato com os diretores e avaliarem melhor essa interação em comparação com os estudantes das instituições privadas. Além disso, o papel desempenhado pelo diretor dentro das instituições públicas e privadas de ensino se difere quanto as suas demandas, tarefas e atribuições, o que pode também influenciar na relação estabelecida com os alunos.

No caso das escolas privadas o maior percentual de avaliação "boa/muito boa" sobre as relações interpessoais foi relativo aos professores $(83,7 \%)$, seguido dos colegas de turma $(83,2 \%)$ e dos funcionários da escola $(80,4 \%)$, enquanto a coordenação obteve o maior percentual $(4,3 \%)$ de avaliação "ruim/muito ruim", mas ainda assim pode ser considerado um baixo percentual. Nas escolas públicas, os atores escolares que receberam mais avaliações "boa/muito boa" dos alunos foram os funcionários da escola $(87,5 \%)$, seguidos pelos professores $(80 \%)$ e os colegas de turma $(77,5 \%)$, sendo que esse último também recebeu o maior percentual de avaliações "ruim/muito ruim" (20\%). Podemos perceber que em ambas as escolas as relações com os colegas de turma, professores e funcionários da escola foram as mais bem avaliadas, alterando apenas a ordem entre as instituições.

Por fim, esses resultados nos mostram que, no geral, os jovens participantes da nossa pesquisa avaliam bem as suas relações com os atores escolares. Esse resultado está em consonância com os achados de Vinha et al. (2017) que buscaram aferir a percepção de alunos de $7^{\circ}$ ao $9^{\circ}$ ano de quatro escolas públicas do interior de São Paulo sobre algumas dimensões do clima escolar. Os autores encontraram 
que os alunos se mostraram, em geral, satisfeitos com as relações que tinham com os colegas e com os professores das suas escolas.

A boa percepção dos jovens da nossa pesquisa sobre a dimensão relacional na sua escola traz indicativos importantes tendo em vista a literatura que discute os benefícios da existência de interações de qualidade dentro das instituições, como a maior satisfação dos estudantes com a escola (VINHA et al., 2017; COELHO E DELL'AGLIO, 2019), o melhor desempenho nas avaliações (CASSASUS, 2008), o maior bem-estar no ambiente escolar (ALCANTARA et al., 2019), menor incidência de bullying (COELHO, 2019) e maior autoestima dos alunos (THAPA et al., 2013). Além disso, a literatura sobre juventude e escola discute a importância das relações estabelecidas no espaço escolar para a permanência dos alunos nas instituições (DAYRELL e JESUS, 2015) e para a percepção positiva do espaço escolar (SANTOS, NASCIMENTO e MENEZES, 2012). Sendo assim, saber que tipo de laços e relações os alunos estão construindo dentro do ambiente escolar é de grande valia para pensarmos sobre as trajetórias dos jovens nas instituições educacionais.

\subsection{3.}

\section{A percepção dos jovens sobre o clima acadêmico}

Neste estudo, o clima acadêmico das instituições foi analisado a partir de dois aspectos: o compromisso do professor com a aprendizagem do aluno e o ambiente disciplinar em sala de aula. A percepção dos alunos sobre o compromisso dos professores com sua aprendizagem está associado a percepção dos alunos sobre o apoio e os esforços dos professores em relação a sua aprendizagem, expressos na frequência com que os professores corrigem os deveres de casa, na demonstração de interesse dos professores no aprendizado do aluno, se os professores perguntam aos alunos se tiveram dúvidas, se os professores ajudam todos os alunos que sentem dificuldades na disciplina, se os professores falam como os alunos podem melhorar seu desempenho e se oportunizam momentos de participação e contribuição dos alunos durante as aulas.

Os resultados da nossa pesquisa, apresentados na tabela 14, apontam que os jovens das escolas públicas percebem mais positivamente o compromisso dos seus professores com a aprendizagem se comparado aos alunos das escolas privadas. No entanto, podemos considerar que, no geral, os jovens de ambas os tipos de escola 
têm uma boa percepção sobre o compromisso dos professores com a sua aprendizagem.

Tabela 14 - Percepção dos jovens sobre o compromisso dos professores com a aprendizagem

\begin{tabular}{lcc}
\hline & Escolas Públicas & Escolas Privadas \\
\hline Ruim & $0,0 \%$ & $3,8 \%$ \\
Intermediária & $27,5 \%$ & $29,9 \%$ \\
Boa & $72,5 \%$ & $64,9 \%$ \\
\hline
\end{tabular}

Fonte: Elaboração da autora com base no questionário "Jovens e escolas: quais as relações?"

Esses achados reafirmam os resultados encontrados por Vinha et. al (2017) com alunos de escolas públicas de São Paulo. Na pesquisa dos autores, os alunos também demonstraram ter percepções positivas acerca dos processos de ensino e aprendizagem, expressando a percepção de que a maioria dos professores explicavam de forma clara, davam aulas interessantes, valorização a produção dos alunos e os incentivavam a perguntar várias vezes até entender, assim como encontrado em nossa pesquisa.

Esses resultados são importantes tendo em vista os estudos que apontam o impacto de professores compromissados e que apoiam os alunos na trajetória escolar. Um estudo elaborado pelo Instituto Unibanco em 2015 revelou que os alunos consideram bons professores aqueles docentes que se preocupam com o aprendizado do aluno, incentivam a participação em sala de aula e não desistem daqueles que não aprenderam - ou seja, que tem características que se associam ao compromisso com a aprendizagem - e que a existência de bons professores no ambiente escolar era vista pelos alunos como um motivo para continuar os seus estudos (ABRAMOVAY, CASTRO e WAISELFISZ, 2015). Outros estudos apontam a importância do compromisso dos professores com a aprendizagem para o desempenho dos alunos (DUARTE e OLIVEIRA; MELO e MORAIS, 2019).

Outro aspecto do ambiente acadêmico analisado pela nossa pesquisa foi a disciplina em sala de aula. Uma pesquisa realizada pelo Instituto Lemann em $2014^{15}$ apontou que a indisciplina é o segundo fator mais citado pelos professores como desafio urgente para ser enfrentado no ambiente escolar. Além disso, a Pesquisa Internacional sobre Ensino Aprendizagem (TALIS) de 2013 desenvolvida pela Organização para a Cooperação e Desenvolvimento Econômico (OCDE) apontou

${ }^{15}$ Fonte: https://direcionalescolas.com.br/fundacao-lemann-realiza-pesquisa-inedita-que-mostra-avisao-dos-professores-sobre-a-educacao-no-brasil/. Acessado em: 15 de dezembro de 2020. 
que os docentes brasileiros foram os que mais relataram ter problemas de comportamento em sala de aula e os que perdem mais tempo de aula tentando manter a disciplina dos alunos (OCDE, 2013).

A partir do nosso questionário buscamos saber como os jovens participantes da pesquisa percebem a indisciplina em sala de aula, refletida na existência de desordem e confusão em sala de aula, dificuldade dos alunos escutarem o que os professores dizem e a necessidade dos professores precisarem esperar um longo tempo até a turma ficar em silêncio. Quando comparamos as respostas dos alunos das instituições públicas e privadas, verificamos que os alunos das escolas públicas têm uma percepção mais negativa sobre o clima disciplinar do que os jovens das escolas privadas. Enquanto $60 \%$ dos alunos das escolas públicas avaliaram a disciplina em sala de aula como "ruim", apenas 25\% dos alunos das escolas privadas tiveram essa avaliação. A grande maioria dos jovens das instituições privadas avaliaram a disciplina dos seus pares como "intermediária". A tabela a seguir apresenta os nossos achados.

Tabela 15 - Percepção dos jovens sobre o clima disciplinar da sala de aula

\begin{tabular}{lcc}
\hline & Escolas Públicas & Escolas Privadas \\
\hline Ruim & $60,0 \%$ & $25,0 \%$ \\
Intermediária & $40,0 \%$ & $70,7 \%$ \\
Boa & $0,0 \%$ & $4,3 \%$ \\
\hline
\end{tabular}

Fonte: Elaboração da autora com base no questionário "Jovens e escolas: quais as relações?"

Os resultados obtidos pela nossa pesquisa corroboram os resultados do PISA de 2009 que indicam que escolas com maior percentual de estudantes socioeconomicamente favorecidos, como no caso das escolas privadas de nossa pesquisa, tendem a ter um clima disciplinar melhor (OCDE, 2013). Os resultados também se alinham aos encontrados por Vinha et al. (2017), em que mais da metade dos alunos das escolas públicas por eles pesquisadas afirmaram que os estudantes atrapalhavam em algumas ou todas as aulas e que alguns professores não conseguiam manter a ordem em sala de aula.

Tanto o compromisso dos professores com a aprendizagem dos alunos, como a disciplina em sala de aula são subdimenções do clima acadêmico que medimos nesta pesquisa. A análise dos dados coletados indica que em nossa pequena amostra de escolas públicas e privadas, a percepção dos alunos sobre o 
apoio e interesse dos professores na sua aprendizagem foi mais positiva do que sua avaliação sobre o comportamento dos seus pares em sala de aula.

\subsection{4.}

\section{A percepção dos jovens sobre o bullying e a discriminação no ambiente escolar}

Em nossa revisão bibliográfica, foi possível encontrar um significativo número de estudos que tratam sobre bullying e discriminação no ambiente escolar, o que retrata o crescimento dessa temática nos últimos anos. Grande parte dos estudos buscam compreender quais são os fatores que aumentam a incidência de violência no espaço escolar (CUNHA, 2014; FERRANS, 2014; SILVA; COSTA, 2016) e quais são as consequências do bullying para a trajetória dos jovens (ALCANTARA et al., 2019; MELO; MORAIS, 2019; KLEIN; CORNELL; KONOLD, 2012).

Nos resultados de nossa pesquisa tanto os jovens das escolas públicas como os jovens das escolas privadas relataram maior incidência de bullying do que de discriminação nas instituições. No entanto, a incidência desses dois tipos de práticas foi recorrente em todas as escolas.

No que se refere à discriminação, 40\% dos alunos das escolas públicas reconheceram que já presenciaram situações de discriminação na escola. Nas instituições privadas esse percentual foi de 50,5\%. Quando perguntamos sobre a existência de bullying, 75,8\% dos alunos das escolas públicas disseram que já presenciaram situações de bullying na escola, enquanto entre os alunos das escolas privadas esse percentual foi de $69,50 \%$. 
Gráfico 19 - Eu nunca presenciei situações de discriminação na escola

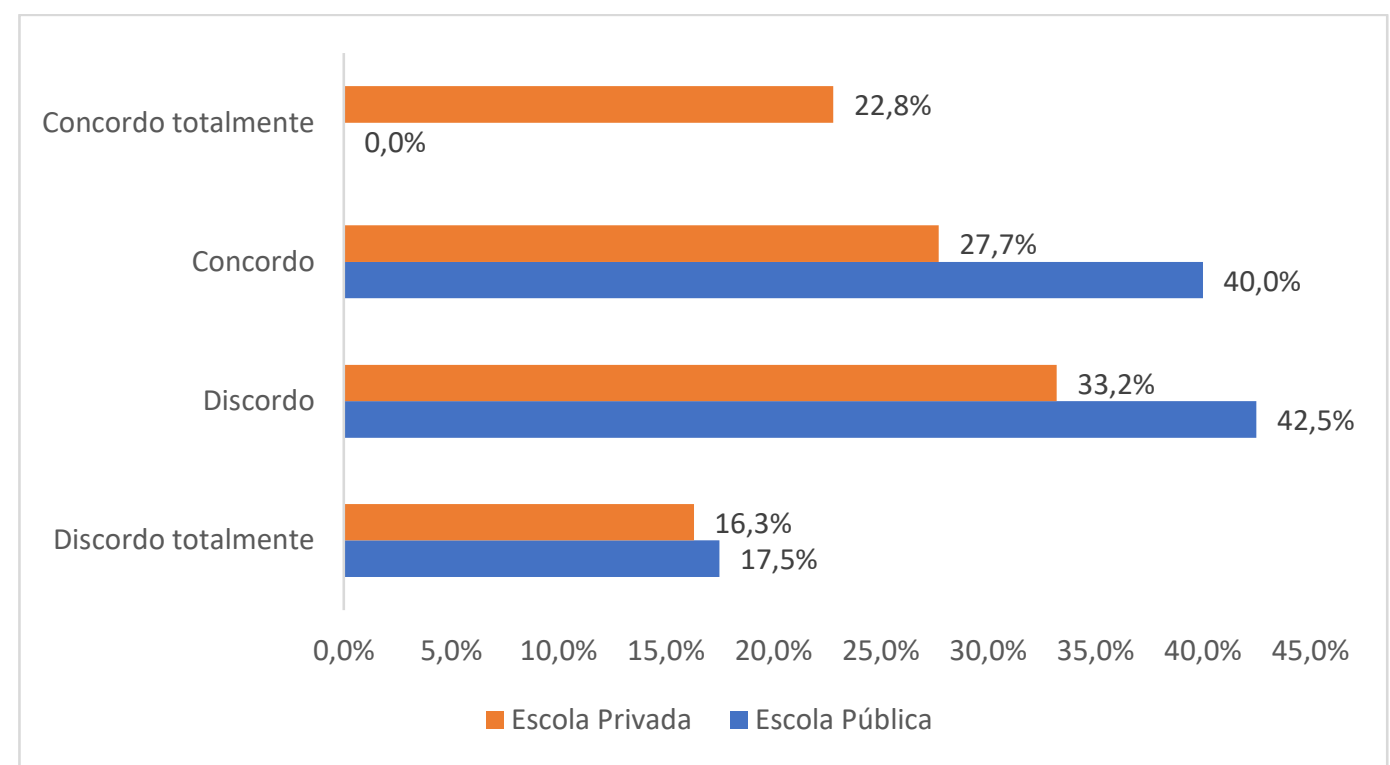

Fonte: Elaboração da autora com base no questionário "Jovens e escolas: quais as relações?"

\section{Gráfico 20 - Eu nunca presenciei situações de bullying na minha escola}

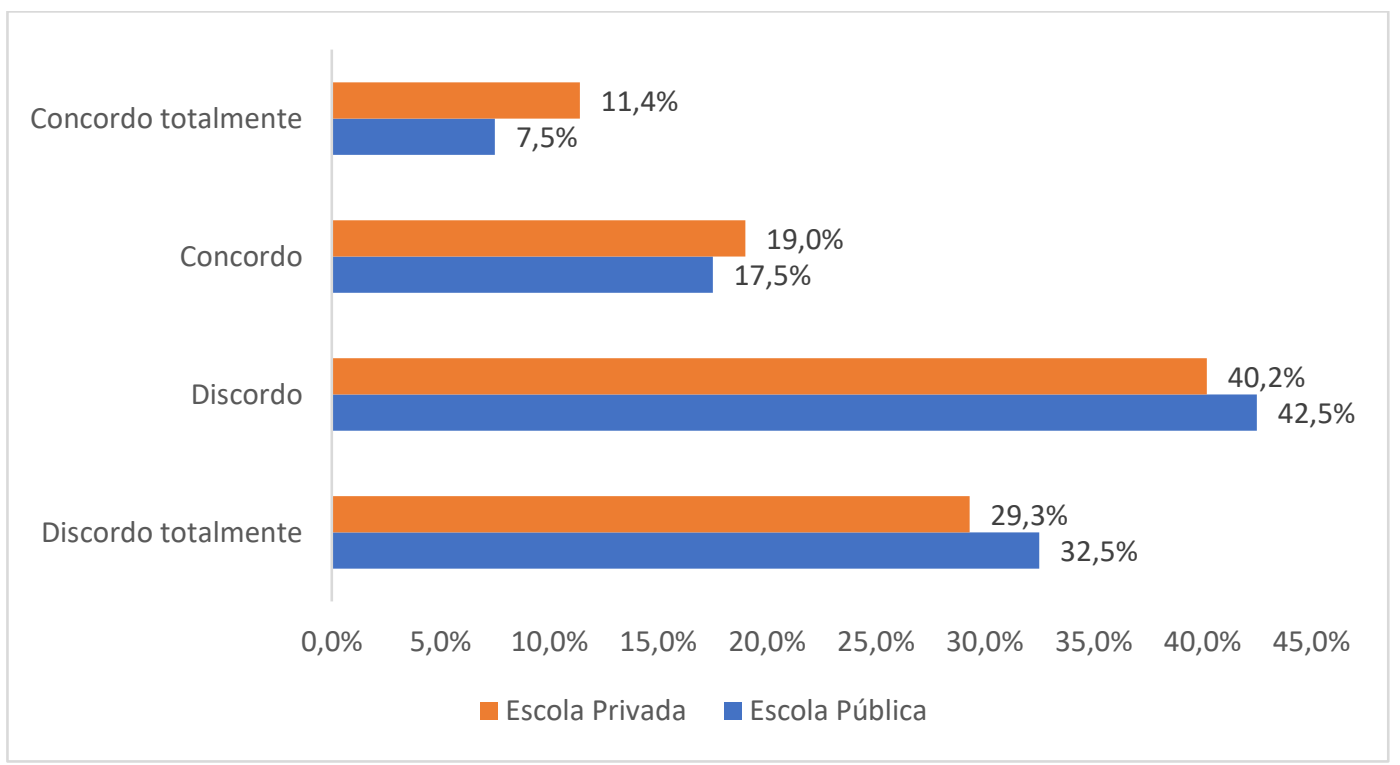

Fonte: Elaboração da autora com base no questionário "Jovens e escolas: quais as relações?

Vinha et al. (2017) encontraram que $87 \%$ dos alunos participantes de sua pesquisa relataram ter percepções positivas sobre a dimensão "situações de intimidação entre alunos", especialmente entre os discentes das escolas públicas analisadas pelos autores. Por outro lado, o resultado da nossa pesquisa converge com os apresentados anteriormente (seção 6.3.2) sobre a qualidade das relações estabelecidas entre os alunos das escolas, já que os estudantes das escolas privadas 
relataram ter melhores relações com os colegas da turma e com outros colegas da escola na comparação com os alunos das escolas públicas.

Estes achados podem trazer indicativos acerca da qualidade do clima das instituições. De acordo com Cunha (2014) e Silva e Costa (2016), quanto melhor a percepção sobre o clima, menores seriam as chances de ocorrer intimidação entre pares na escola e, segundo Silva e Costa (2016, p. 645):

O bullying indica ainda a incapacidade da instituição de promover um ambiente de convívio saudável entre os alunos. Certamente, uma escola com altos índices de bullying possui problemas organizacionais e inter-relacionais, entre os quais o bullying é apenas uma das facetas visíveis.

A pesquisa desenvolvida por Silva e Costa (2016) apontou que algumas dinâmicas das próprias instituições podem ser decisivas para a ocorrência de bullying no espaço escolar, como a insatisfação dos alunos com a instituição, a agressividade no trato dos professores com os alunos, a presença de polícia na escola e a utilização de punições severas para conter conflitos. Vimos nas seções anteriores, que tanto os alunos das escolas públicas como os das escolas privadas da nossa amostra retrataram ter boas relações com os docentes da escola, acreditando, inclusive, no seu compromisso com a aprendizagem discente.

Por fim, a centralidade que as situações de bullying e discriminação têm na vida escolar dos jovens ficou clara a partir dos relatos dos alunos ao final do instrumento, no espaço que pedíamos para que eles registrassem algum comentário ou informação que julgassem importante. Alguns jovens deixaram mensagens relatando o incomodo com a ocorrência de situações desse tipo em suas escolas, como mostram os trechos das mensagens abaixo:

"A minha escola tinha que ser mais política e ter mais palestras e projetos sobre diretos humanos, muitos alunos são preconceituosos e elitistas" (Aluno(a) da escola E-Particular do Rio de Janeiro).

"Vários alunos são muito mimados, preconceituosos e por viver em uma realidade diferente da minha, acabam me tratando diferente" (Aluno(a) da escola E-Particular do Rio de Janeiro).

"Em minha opinião a escola não nos torna pessoas inteligentes e cultas, e muitas pessoas da minha turma são totalmente ignorantes, e preconceituosas" (Aluno(a) da escola B-Particular de São Luís). 
O fato dos alunos discorrerem sobre esses episódios em um momento em que eles poderiam escrever sobre qualquer assunto ou, até mesmo, não escrever nada, mostra o incomodo com as situações de bullying e discriminação que permeiam o ambiente em que estudam.

\subsection{5.}

\section{Percepção dos jovens sobre a regras e sanções da escola}

Tendo em vista o grande número de pesquisas que indicam como a percepção dos alunos sobre as regras e sanções existentes na escola influencia a qualidade do clima nas instituições de ensino (THAPA et. al, 2013; VINHA et al., 2017; CADIAN e RESENDE, 2013a; COELHO e DELL'AGLIO, 2019), nosso questionário busca aferir em que medida os jovens consideravam que as regras e sanções da sua escola eram claras e justas para todos os alunos.

Os resultados indicaram que os alunos das escolas privadas têm uma percepção mais positiva sobre a justiça e clareza das regras das suas instituições em comparação com os alunos das escolas públicas, tendo em vista que nenhum (0\%) dos alunos das escolas públicas alegou ter uma boa percepção sobre o clima normativo das suas escolas e $40 \%$ alegou ter uma percepção ruim sobre esse aspecto. No que se refere às escolas privadas, apenas $4,9 \%$ dos jovens indicou ter uma percepção ruim sobre a justiça e a clareza das regras da escola. Por fim, em ambas as escolas, a maioria dos alunos indicou ter uma percepção intermediária sobre o clima normativo das suas instituições, como mostra a tabela 6 a seguir.

Tabela 16 - Percepção dos jovens sobre a justiça e clareza das regras e sanções

\begin{tabular}{lcc}
\hline & Escolas Públicas & Escolas Privadas \\
\hline Ruim & $40,0 \%$ & $4,9 \%$ \\
Intermediária & $60,0 \%$ & $60,3 \%$ \\
Boa & $0,0 \%$ & $34,8 \%$ \\
\hline Fonte: Elaboraç̃o da autora com
\end{tabular}

Fonte: Elaboração da autora com base no questionário "Jovens e escolas: quais as relações?"

Diferente do nosso estudo, Vinha et al. (2017) encontrou uma boa percepção dos alunos das escolas públicas presentes em sua amostra sobre a dimensão "As regras, as sanções e a segurança na escola”. Na pesquisa dos autores, 67,7\% dos jovens indicaram ter uma boa percepção sobre o clima normativo das instituições. Em que pese nossa limitação quanto a quantidade de respondentes e de escolha das escolas, esses resultados são importantes na medida que o senso de justiça das 
regras e sanções presentes na escola vem sendo associado por várias pesquisas a diversos aspectos da trajetória dos estudantes. As pesquisas desenvolvidas por Candian e Rezende (2013), Melo e Morais (2013) e Duarte e Oliveira (2017) apontaram relações positivas entre o clima normativo da escola e o desempenho dos estudantes em avaliações de larga escala. Além disso, Coelho e Dell'Aglio (2019) identificaram que a dimensão "Justeza das regras e clareza das expectativas" foi uma das que mais se associou à satisfação do aluno no espaço escolar. Com base nessas considerações, podemos inferir que esse aspecto poderia ser mais investigado no futuro.

\subsection{6.}

\section{O sentimento de pertencimento dos jovens em relação ao ambiente escolar}

O sentimento de pertencimento dos jovens em relação às suas escolas foi a última dimensão do clima analisada considerando que "a dimensão do pertencimento, transcende qualquer uma das outras, na medida em que se constrói a partir de todas as demais" (VINHA et al. 2017, p. 166). Assim como para alguns autores o pertencimento se constitui como uma dimensão do clima, ele também pode ser entendido como o resultado da percepção dos atores sobre todas as outras dimensões da escola (relações interpessoais, intimidação entre pares, infraestrutura, clima acadêmico e a justiça e clareza das regras).

A literatura internacional (THAPA et al., 2010; LOUKAS, 2007) utiliza o termo "school conecteness" ou, no português, conexão com a escola, para se referir ao sentimento de pertencimento do aluno em relação ao seu espaço escolar. De acordo com o Centro para Controle e Prevenção de Doenças (2009), school conecteness seria a crença dos alunos de que adultos e colegas da escola se preocupam com seu aprendizado e com eles enquanto indivíduos. No caso desta pesquisa, decidimos utilizar o termo pertencimento, já utilizado por outros autores brasileiros (CANGUÇU, 2015; COELHO; DELL'AGLIO, 2019) como alternativa para aferir em que medida os alunos gostavam da escola em que estudam, se eles se sentiam valorizados e reconhecidos nesse espaço e se tinham orgulho de serem alunos da instituição. De acordo com Thapa et al. (2010), a conexão do aluno com o espaço escolar tem se apresentado como um poderoso preditor associado à saúde 
dos adolescentes e os seus resultados acadêmicos, com a satisfação dos alunos com a escola e como fator protetivo contra violência sexual e uso de drogas.

Para a análise dessa dimensão criamos o índice de pertencimento classificando o sentimento de pertencimento e conexão dos alunos com suas escolas como "alto", "intermediário" e "baixo" de acordo com as medidas de corte estabelecidas e apresentadas no apêndice B.

Como a tabela 17 apresenta, os alunos das escolas privadas possuem um sentimento de pertencimento maior do que os alunos das escolas públicas. Enquanto $43,9 \%$ dos jovens das escolas privadas relataram se sentirem altamente pertencentes ao seu espaço escolar, apenas $10 \%$ dos alunos das escolas públicas relataram o mesmo. A grande maioria dos alunos das escolas públicas que responderam ao nosso questionário se sentem mais ou menos pertencentes a esse espaço.

Tabela 17 - Nível de pertencimento dos alunos em relação às suas escolas

\begin{tabular}{lcc}
\hline & Escolas Públicas & Escolas Privadas \\
\hline Baixo & $10,0 \%$ & $5,4 \%$ \\
Intermediário & $80,0 \%$ & $51,6 \%$ \\
Alto & $10,0 \%$ & $43,9 \%$ \\
\hline
\end{tabular}

Fonte: Elaboração da autora com base no questionário "Jovens e escolas: quais as relações?"

Tendo em vista que o sentimento de pertencimento do aluno é construído a partir da sua percepção sobre outros fatores presentes na escola, o resultado apresentado acima pode estar relacionado com outros já discutidos neste capítulo. Como vimos anteriormente, os alunos das escolas públicas foram os que relataram piores percepções nas dimensões justiça e clareza das regras da escola, bullying e discriminação, disciplina em sala de aula, relação com os alunos da sala e outros colegas da escola e a infraestrutura da instituição escolar. Considerando esses resultados, era esperado que o sentimento de pertencimento dos jovens estudantes das escolas públicas fosse inferior se comparado com os alunos das escolas privadas.

É importante lembrar, contudo, que os efeitos do clima escolar assim como as condições que vão originar o clima podem estar muito conectados, justamente porque o ambiente escolar é dinâmico e as dimensões do clima estão muitas vezes relacionadas umas com as outras (THAPA et al., 2013). Infelizmente, devido aos limites em termos quantitativos e qualitativos da coleta de dados nesse trabalho, 
não será possível identificar as relações de causa e efeito entre as variáveis, ou seja, se a percepção negativa sobre algumas dimensões do clima faz com que os alunos se sintam menos pertencentes a esse lugar ou se pelo fato dos alunos não se sentirem pertencentes a esse espaço, a percepção sobre o clima é pior.

Ainda assim, cabe ressaltar que não verificamos situações completamente antagônicas em relação ao pertencimento, uma vez que os alunos das escolas privadas se dividiram entre as situações de pertencimento alto e intermediário, ao passo que os das escolas públicas se concentraram no nível intermediário. Estes resultados exploratórios no universo limitado da amostra estudada indicam a necessidade de mais estudos sobre o tema. Nossos achados, embora pouco avancem em termos da compreensão do fenômeno, se alinham a outros estudos que apontam o sentimento de pertencimento como uma das dimensões mais explicativas de um clima escolar positivo (CANGUÇU, 2015) e inversamente associada a contextos de violência e vitimização escolar (SILVA; COSTA, 2016).

\section{4. \\ A percepção dos alunos sobre a participação discente no espaço escolar}

A crescente discussão sobre a importância da participação discente no espaço escolar (MARTINS; DAYRELL, 2013; ROMANCI; CASTILHO, 2016; MITRA et al. 2012; THOMPSON, 2009) nos motivou a buscar saber como os jovens presentes em nossa amostra percebiam a sua atuação no espaço escolar. Para isso, perguntamos a eles se a escola em que estudavam possuía grêmio estudantil ou outra forma de organização e participação estudantil, se eles achavam que os alunos deveriam participar das decisões da escola que lhes diziam respeito e como eles avaliavam sua participação no espaço escolar.

Praticamente todos os alunos, 95,1\% dos jovens das escolas privadas e $90 \%$ dos alunos das escolas públicas, acharam que deveriam participar das decisões da escola que lhes dizem respeito. Quando perguntamos como eles avaliavam a sua participação nesse espaço, a maior parte dos alunos das escolas públicas e das escolas privadas ( $40 \%$ e $45,7 \%$, respectivamente) disse que não participava das decisões da escola, mas que gostaria de participar. Esses resultados parecem indicar que os jovens se sentem alijados dos espaços de participação do ambiente escolar, apesar de acreditarem e desejarem contribuir para a tomada de decisões nesses 
espaços. Foi ainda possível perceber que esses sentimentos fazem parte tanto dos jovens que estudam nas instituições públicas como nas privadas presentes em nossa amostra. Os gráficos abaixo mostram com mais detalhes os resultados encontrados.

\section{Gráfico 21 - Os alunos devem participar das decisões da escola que dizem respeito a eles?}

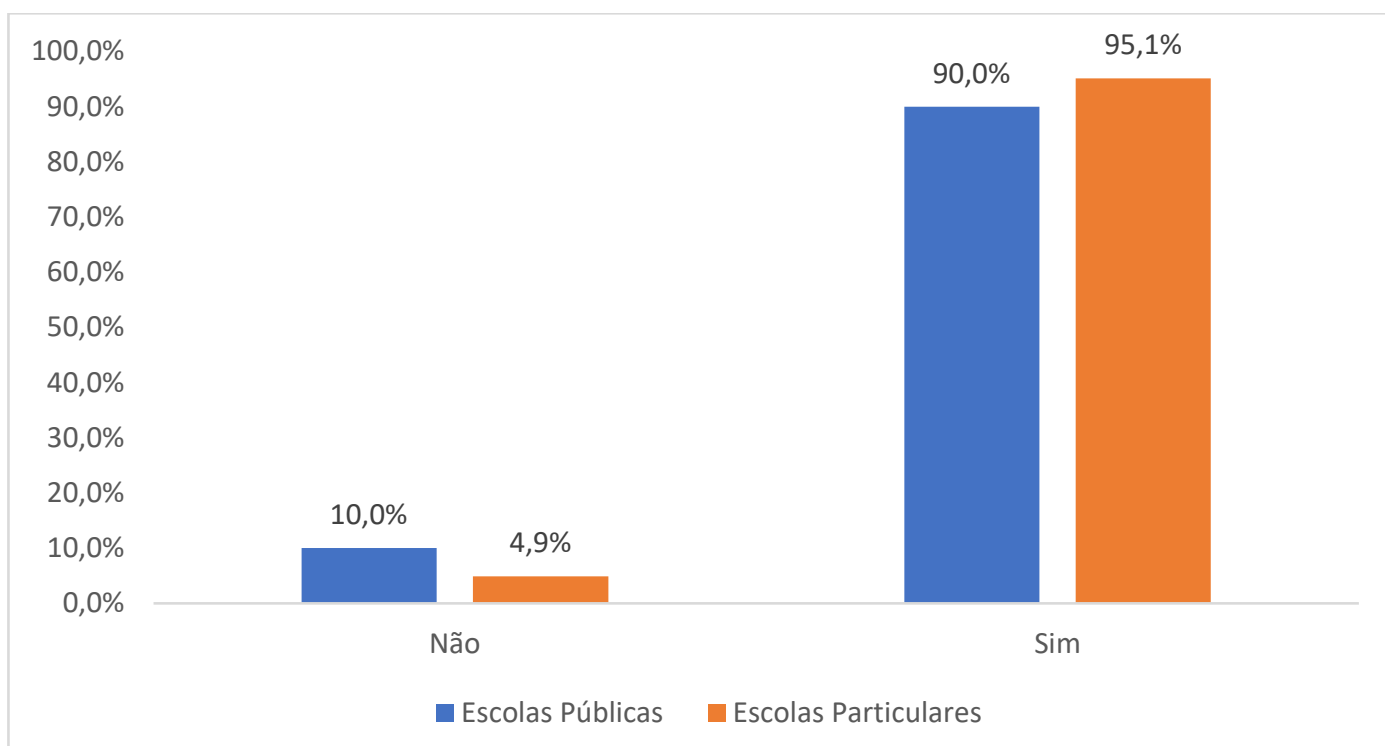

Fonte: Elaboração da autora com base no questionário "Jovens e escolas: quais as relações?" Gráfico 22- Opinião dos jovens sobre o seu nível participação nas decisões da
escola que dizem respeito a eles.

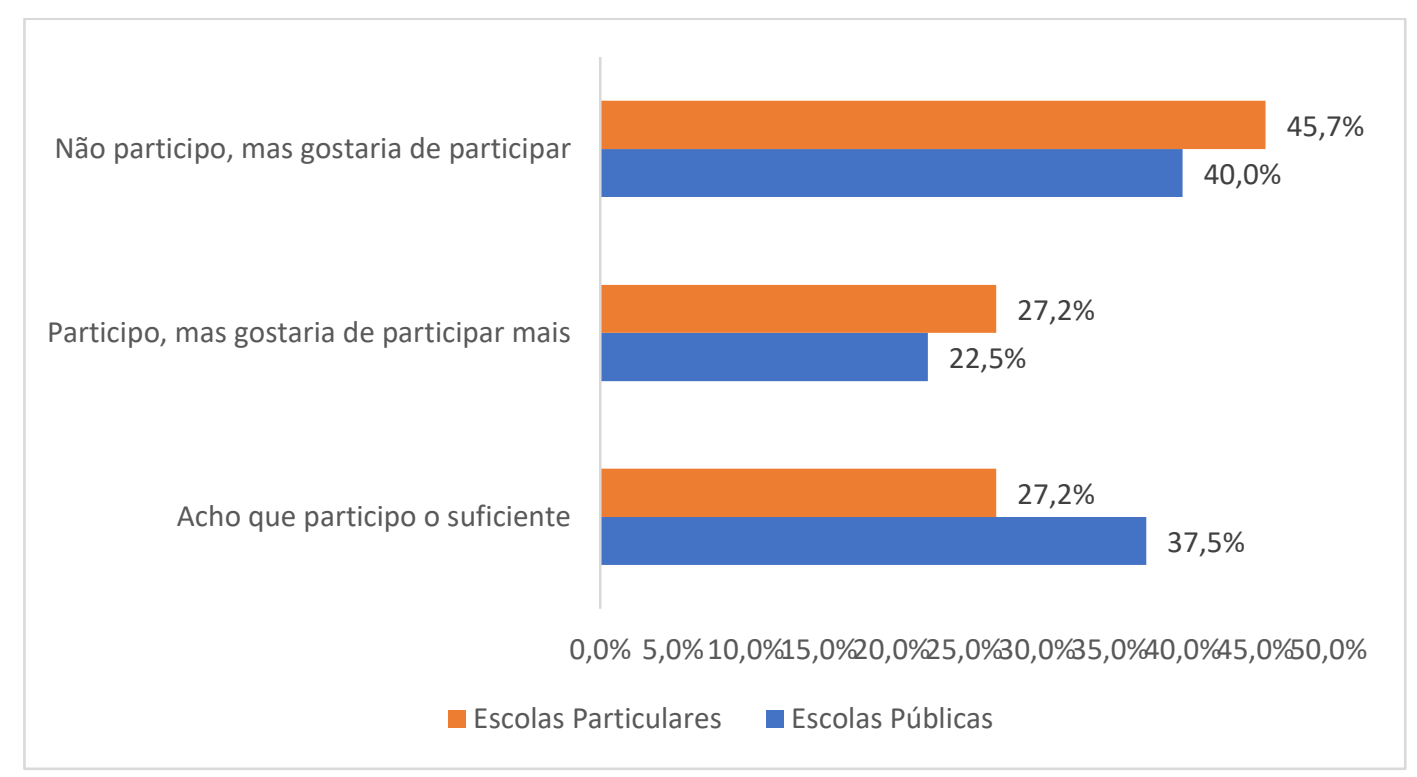

Fonte: Elaboração da autora com base no questionário "Jovens e escolas: quais as relações?"

Também perguntamos aos alunos se havia grêmio estudantil ou outra forma de participação estudantil em suas escolas e, como já mencionado no capítulo 5 
(5.2.1), surgiram algumas dúvidas sobre o que seria um "grêmio estudantil" em duas das escolas privadas presentes em nossa amostra. Esse fato nos faz refletir sobre a possível necessidade de reformular esse item do questionário, bem como sobre a possibilidade desse desconhecimento ser em decorrência da pouca discussão sobre espaços de participação discente nessas instituições privadas. De toda forma, os resultados da nossa pesquisa apontaram que $62 \%$ dos alunos das escolas privadas afirmaram ter grêmio estudantil ou outra forma de participação discente em sua escola e $47 \%$ dos alunos das escolas públicas afirmaram o mesmo.

Gráfico 23 - Existe grêmio estudantil ou outras formas de participação estudantil na sua escola?

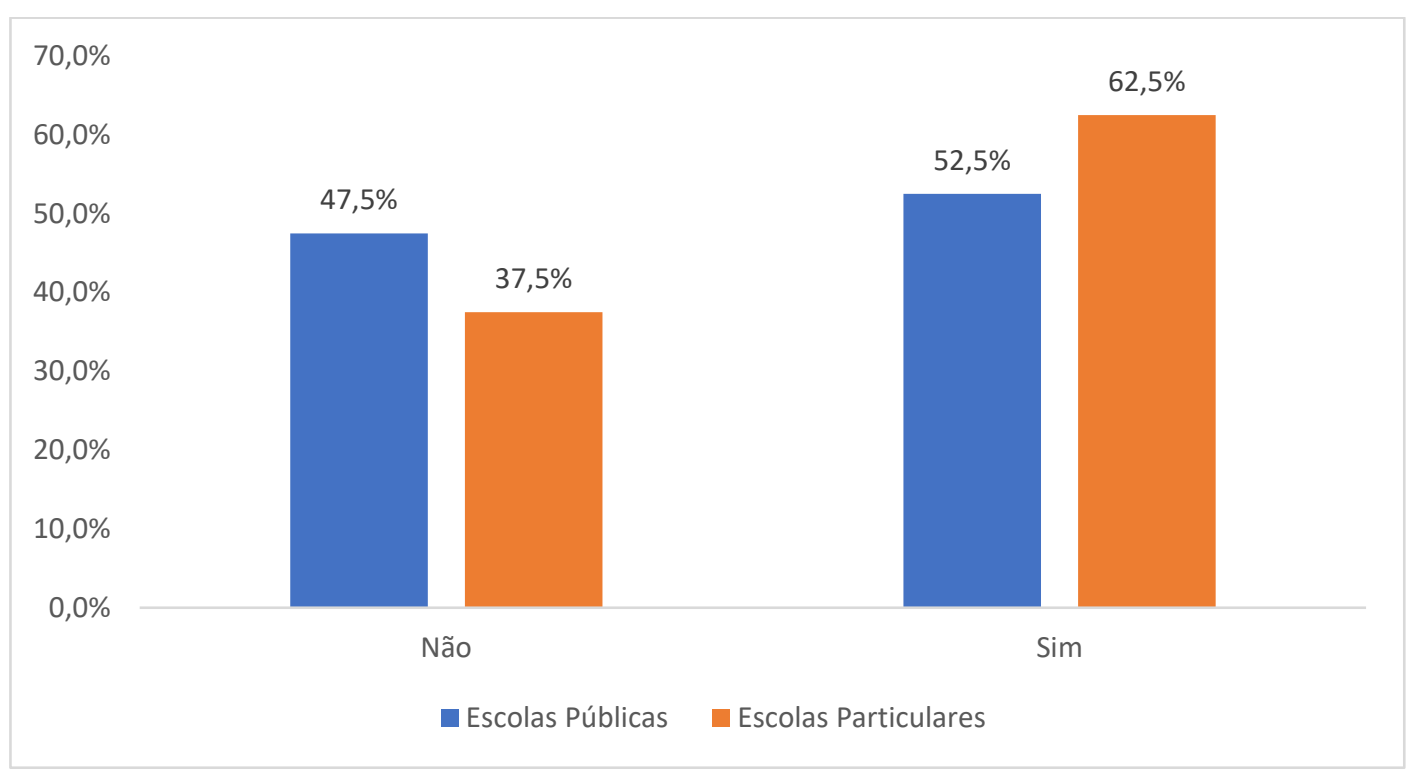

Fonte: Elaboração da autora com base no questionário “Jovens e escolas: quais as relações?”

Outros itens sobre participação presentes em nosso questionário permitiram criar um Índice de percepção dos alunos sobre a participação discente no espaço escolar. Para a criação desse índice, perguntamos aos alunos em que medida eles concordam que certas práticas acontecem em suas escolas: os alunos são convidados a darem as suas opiniões sobre o que é melhor para turma ou para a escola, suas opiniões são ouvidas e consideradas pelos demais atores escolares e os alunos participam da elaboração e da mudança das regras da escola. A partir das respostas dos alunos criamos três categorias de percepção de participação discente "baixa participação", "intermediária participação" e "alta participação" (ver o detalhamento no Apêndice B). 
Como mostra a tabela 18, 30\% dos alunos das escolas públicas consideram que a sua participação no espaço escolar é alta, enquanto apenas $13 \%$ dos alunos das escolas privadas consideram que a participação discente é alta na sua instituição. De forma geral, a maior parte dos alunos das escolas públicas e privadas acreditam que a sua participação no espaço escolar é intermediária.

Tabela 18 - Percepção dos alunos sobre o nível de participação discente na sua escola

\begin{tabular}{lcc}
\hline & Escolas Públicas & Escolas Privadas \\
\hline Baixa & $20,0 \%$ & $21,7 \%$ \\
Intermediária & $47,5 \%$ & $64,1 \%$ \\
Alta & $30,0 \%$ & $13,0 \%$ \\
\hline
\end{tabular}

Fonte: Elaboração da autora com base no questionário "Jovens e escolas: quais as relações?"

Quando comparamos o resultado do índice de percepção dos jovens sobre a participação discente e o resultado do gráfico 23 sobre os espaços de participação na escola, é possível perceber um contraste nas respostas, tendo em vista que os alunos das escolas privadas relataram ter mais espaços de participação na escola, no entanto, não consideram que participam das decisões da vida escolar. Esse contraste de resultados pode indicar que, apesar das escolas privadas terem mais espaços organizados de participação, ainda assim os alunos não se sentem ouvidos ou considerados pelos atores escolares. Esse tipo de situação foi mencionado por outros autores como Robson e Taylor (2013) que atentaram para existência de relações de poder ocultas e explícitas entre os atores escolares e os estudantes mesmo em escolas que buscavam amplificar a voz dos alunos e Jones e Bubb (2020) que identificaram uma alta regulação dos conselhos escolares pelos professores, dando pouca autonomia dos alunos se posicionarem nesse espaço. Em ambas os estudos, os autores identificaram políticas de amplificação das vozes dos alunos nas escolas pesquisadas, no entanto, ainda havia dificuldades para a implementação plena dessas políticas.

A relação desses resultados com os demais encontrados ao longo da nossa pesquisa, como o sentimento de pertencimento dos alunos no espaço escolar e as situações de intimidação entre pares, por exemplo, contrasta com outros estudos desenvolvidos no campo. Vinha et al. (2017) apontaram que a existência de assembleias e momentos de participação discente no espaço escolar favorecia o aumento dos sentimentos de justiça, respeito e pertencimento dos estudantes. No entanto, nossa pesquisa apontou que os alunos das escolas públicas embora tenham 
melhores percepções sobre a sua participação no espaço escolar, também relataram maiores índices de bullying e discriminação e níveis mais baixos de pertencimento.

Outros estudos mostram a importância de ambientes mais participativos para a construção de um clima escolar positivo (VINHA et al., 2016; BASTOS, 2019), o que não se verificou em nossa limitada amostra, tendo em vista que os estudantes das escolas privadas mostraram melhores percepções sobre o clima em quase todas as dimensões apesar de relatarem baixa participação discente na escola. Ainda que as limitações na representatividade de nossos resultados desautorizem um questionamento dos resultados encontrados por estes autores, eles parecem indicar a relevância de aprofundar estudos sobre o tema.

Como vimos no capítulo 3, diferentes estudos identificaram os desafios na construção de um ambiente escolar que possibilite a efetiva participação discente nas decisões da escola. Alguns dos obstáculos mencionados pelos autores como a falta de formação dos professores e incentivo dos gestores (LEEK, 2019), o não reconhecimento por parte dos atores escolares das oportunidades de aprendizagem que podem estar presentes nos espaços de participação (DAYRELL; GOMES; LEÃO, 2010), a dificuldade de rompimento com padrões hierárquicos já estabelecidos e naturalizados no ambiente escolar (MARTINS; DAYRELL, 2013; MILTRA et al., 2012; THOMPSON, 2009; JONES; BUBB, 2020) e, no caso do Brasil, a falta de legislações claras sobre os princípios e obrigações de uma gestão democrática (ARELARO; JACOMI, CARNEIRO, 2016), podem estar presentes nas escolas pesquisadas, fazendo com que, por mais que existam espaços organizados de participação como grêmio estudantil ou outras ações, ainda assim os alunos se sintam pouco ouvidos e considerados pelos atores escolares.

Considerando nossos limites empíricos na pesquisa, apenas podemos concluir que, nas instituições pesquisadas, não houve uma correlação entre maior participação discente e melhores percepções dos alunos sobre o clima escolar.

\section{5.}

\section{Crenças de autoeficácia dos jovens participantes da pesquisa}

As crenças de autoeficácia dos alunos, ou seja, o julgamento pessoal dos jovens acerca das suas capacidades de realizar determinadas tarefas, tem se mostrado como um fator que influencia fortemente a vida dos jovens no âmbito pessoal e acadêmico (DOMÉNECH-BETORET et al., 2017; OLIVEIRA; 
SOARES, 2011; EL ACHKAR et al., 2017; BURGER; SAMUEL, 2017; MAGNANELLI et al., 2015). Em nosso estudo, buscamos medir o quanto os jovens presentes em nossa amostra se sentiam capazes de realizar determinadas tarefas acadêmicas, como concluir o ensino médio, ingressar no ensino superior, obter bons resultados nas avaliações e conseguir um bom emprego no futuro, criando o Índice de autoeficácia acadêmica. Para a mensuração do construto, utilizamos as categorias "alta", "intermediária" e "baixa" para nos referirmos ao nível de autoeficácia dos alunos. Os valores utilizados para a categorizar cada um dos níveis se encontram no apêndice B.

No que se refere à autoeficácia acadêmica, a tabela 19 apresentada a seguir mostra que os alunos das escolas privadas se consideram mais capazes do que os alunos das escolas públicas de realizar as tarefas mencionadas. Enquanto 74,3\% dos alunos das escolas privadas se consideram altamente capazes, apenas 42,5\% dos alunos das escolas públicas também se consideram assim. A maior parte dos jovens das instituições públicas $(47,5 \%)$ se consideram mais ou menos capazes e $10 \%$ se consideram pouco capazes de concluir o ensino médio, ingressar no ensino superior, obter bons resultados nas avaliações e conseguir um bom emprego no futuro.

Tabela 19 - Nível de autoeficácia dos jovens por tipo de instituição

\begin{tabular}{lcc}
\hline & Escolas Públicas & Escolas Privadas \\
\hline Baixa & $10,0 \%$ & $3,3 \%$ \\
Intermediária & $47,5 \%$ & $22,3 \%$ \\
Alta & $42,5 \%$ & $74,3 \%$ \\
\hline
\end{tabular}

Fonte: Elaboração da autora com base no questionário "Jovens e escolas: quais as relações?"

Considerando o perfil dos jovens das escolas públicas e privadas presentes em nossa amostra apresentado no capítulo 6 (6.1), nossos resultados corroboram com os achados de Guerreiro-Casanova, Azzi e Dantas (2011) que encontraram que filhos de pais mais escolarizados tendem a ter crenças mais altas de autoeficácia. Da mesma forma, Melo-Silva e Texeira (2015) encontraram associações significativas entre nível socioeconômico mais alto e maior confiança no ingresso no mercado de trabalho. Por fim, nossos resultados estão de acordo com os achados de Doménech-Betoret et al. (2017) que apontaram associações positivas entre autoeficácia e satisfação com a vida escolar, que é uma faceta importante do sentimento de pertencimento. No caso da nossa amostra, os alunos das escolas 
privadas que mostraram níveis mais altos de pertencimento à escola também apresentaram elevada autoeficácia acadêmica.

Butz e Usher (2015), por outro lado, destacaram a importância dos professores como facilitadores e estimuladores das crenças de autoeficácia, principalmente através do seu apoio quando os alunos tinham dificuldade. Em nosso estudo, no entanto, os alunos das escolas públicas tinham melhores percepções sobre o compromisso de seus professores com sua aprendizagem do que os jovens das escolas privadas e, ainda assim, tiveram os primeiros apresentaram crenças mais baixas de autoeficácia. Embora os autores lembrem a importância de se atentar para a individualidade dos alunos e não pensar que existem fórmulas para o estímulo das crenças de autoeficácia dos alunos, esses contrastes apontam para a necessidades de mais pesquisas sobre o tema tendo o ponto de vista dos alunos como fonte privilegiada de investigação.

Também perguntamos aos jovens o quanto eles se sentiam capazes de pensar em soluções para problemas que estivessem acontecendo na escola para avaliar o que Guerreiro-Casanova, Azzi e Dantas (2011) chamam de "autoeficácia para atuar na vida escolar" e Manganelli et al. (2015) denominam de "autoeficácia cidadã", ou seja, a crença na própria capacidade de contribuir e atuar dentro do espaço escolar. Como mostra o gráfico a seguir, $80,9 \%$ dos alunos das escolas privadas se sentem muito ou razoavelmente capazes de pensar em soluções para problemas que estejam acontecendo na escola, enquanto $65 \%$ dos alunos das escolas públicas pensam o mesmo. 
Gráfico 24 - Percepção dos alunos sobre a sua capacidade de pensar em soluções para os problemas da escola

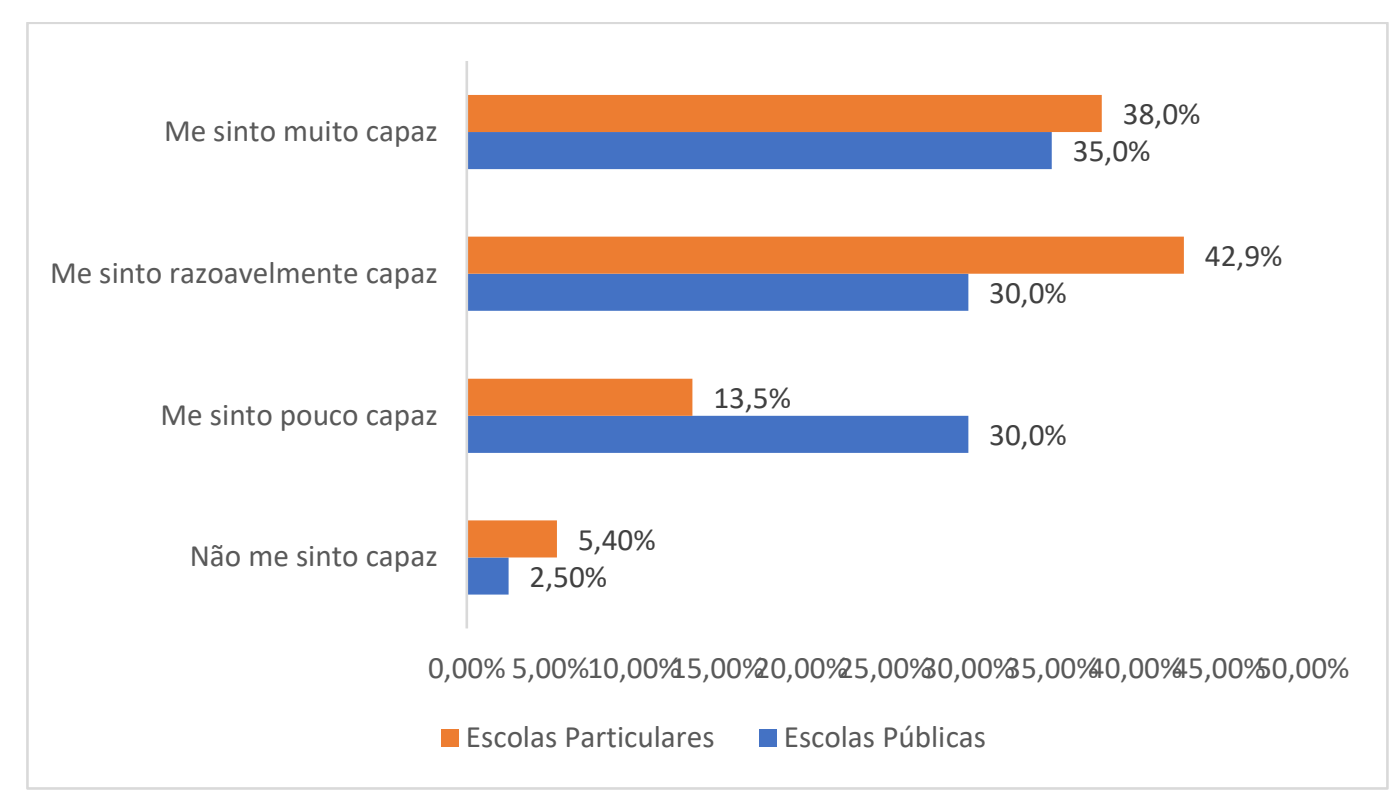

Fonte: Elaboração da autora com base no questionário "Jovens e escolas: quais as relações?"

No estudo de Guerreiro-Casanova, Azzi e Dantas (2011) os alunos mostraram uma percepção baixa de autoeficácia para contribuir com ideias para a melhoria da escola e os autores associaram esse resultado à ausência de ações e estímulos que colocassem o jovem em lugares de protagonismo como agente de mudança no ambiente escolar. Contudo, essa relação não pôde ser aferida em nossa pesquisa, tendo em vista que os alunos das escolas públicas relataram terem mais participação na escola e, ao mesmo tempo, mais baixas taxas de autoeficácia para atuar na vida escolar.

O que podemos concluir a partir das respostas dos alunos no questionário aplicado é que os jovens das escolas privadas pesquisadas se percebem como mais capazes de realizar diferentes tarefas como concluir o ensino médio, ingressar no ensino superior, conseguir uma boa posição no mercado de trabalho, tirar notas boas nas avaliações e pensar em soluções para problemas da escola. Tendo em vista a literatura que discute como as crenças de autoeficácia não apenas afetam a trajetória pessoal e acadêmica dos alunos, mas também são extremamente afetadas pelas experiências vividas nos espaços sociais, como é o caso da escola (MCCOY; BOWEN, 2014; BUTZ; USHER, 2015; MANGANELLI et al., 2015), analisar como os alunos avaliam as suas próprias capacidades de desempenhar determinadas atividades é um importante indicativo não apenas sobre quem são os jovens, mas também sobre as escolas em que estudam. 


\section{7. \\ Considerações Finais}

O objetivo principal deste trabalho foi conhecer as relações que os jovens de escolas públicas e privadas estabelecem com a escola que frequentam. A motivação original para esta pesquisa está relacionada aos índices educacionais que compreendem os anos finais do Ensino Fundamental no país e aos estudos nacionais e internacionais que salientam a importância do estabelecimento de relações saudáveis e positivas entre os alunos e as escolas para o prolongamento com sucesso da trajetória escolar e para o desenvolvimento cognitivo, emocional e social dos jovens.

A revisão de literatura realizada para este trabalho mostrou que a motivação para ir à escola e aprender, a percepção dos alunos sobre o clima escolar, a participação discente nas decisões da escola e a percepção dos jovens sobre as suas capacidades de realizar determinadas tarefas são aspectos importantes que influenciam a forma como os alunos experienciam seu percurso escolar. Tomando como base essa revisão e a constatação da existência de poucos estudos quantitativos que abrangessem todo esse conjunto de questões, construímos um instrumento de pesquisa (questionário) que contemplou itens sobre todos esses aspectos, além de questões sobre hábitos juvenis, trajetória escolar vivida e pretendida e condições sociais e econômicas dos jovens. O instrumento foi aplicado a uma amostra de 224 jovens do $9^{\circ}$ ano do Ensino Fundamental de escolas públicas e privadas localizadas no Rio de Janeiro (RJ) e em São Luís (MA) e, posteriormente, foi validado quanto a sua confiabilidade.

Uma das principais contribuições deste trabalho está justamente na construção de um novo instrumento que busca conhecer a percepção dos jovens sobre as suas respectivas escolas. Como apontam alguns estudos apresentados no capítulo 3 deste trabalho (MITRA; GROSS, 2009; MAGER; NOWAK, 2012; THOMPSON, 2009), dar voz aos jovens e saber o que eles pensam sobre as suas instituições de ensino são importantes mecanismos para melhorar a qualidade e prolongar a trajetória dos estudantes no espaço escolar. Nesse horizonte, a construção do questionário se mostrou como uma possibilidade de escuta e valorização da percepção estudantil sobre o ambiente escolar. A aplicação do instrumento para os alunos do último ano do Ensino Fundamental também se 
configurou uma contribuição relevante do nosso estudo, tendo em vista que grande parte das pesquisas que falam sobre juventude e escola abrangem apenas alunos do Ensino Médio.

Apesar do baixo número de respondentes em nossa pesquisa, a validação empírica do questionário realizada através da técnica de análise fatorial indicou que o instrumento produzido pode ser considerado confiável e eficiente, principalmente para medir os construtos clima escolar (nas dimensões infraestrutura, compromisso do professor com a aprendizagem dos alunos, pertencimento e justiça e clareza das regras da escola), a participação discente e a autoeficácia acadêmica dos alunos. Por outro lado, os índices de mobilização em relação à escola e o índice de percepção sobre a indisciplina em sala de aula foram os que se mostraram menos confiáveis, apresentando valores de Alpha de Cronbach inferiores a 0,7. Esperamos que futuras aplicações do instrumento em amostras maiores e desenhadas de forma mais representativa de diferentes tipos de escola e de grupos sociais poderão testar com mais precisão a eficácia do instrumento, avançar na compreensão das fragilidades encontradas e superá-las.

Outra contribuição deste trabalho pôde ser vista na análise exploratória dos dados, tendo em vista a ainda limitada presença de estudos quantitativos nesse campo. As respostas dos alunos ao questionário evidenciaram que os jovens das escolas públicas e privadas percebem determinados aspectos da sua instituição de forma diferente. Nesse sentido vale destacar que, no geral, os alunos das escolas privadas possuem visões mais positivas sobre a maioria dos aspectos aferidos por nossa pesquisa, como a infraestrutura do espaço escolar, o clima disciplinar, o bullying e a discriminação, a justiça e a clareza das regras e sanções da escola, o sentimento de pertencimento em relação à instituição e, por fim, mostram maior autoeficácia acadêmica. Já os alunos das escolas públicas se mostram mais motivados para irem à escola pelo que esperam aprender, percebem que de forma mais positiva o compromisso dos professores com a sua aprendizagem e acreditam que participam mais das decisões da escola. Ainda que esses dados não sejam representativos de toda a população, podem fornecer indicativos importantes sobre as relações que os jovens de escolas públicas e privadas estabelecem com seu estabelecimento de ensino.

Uma segunda consideração importante pode ser feita quando analisamos o perfil dos jovens que estão presentes em escolas de diferentes dependências 
administrativas. Os alunos das escolas públicas são, em sua maioria, jovens negros e filhos de mães pouco escolarizadas e, também, aqueles que possuem percepções mais negativas sobre a sua escola, o que corrobora outros trabalhos já desenvolvidos internacionalmente que mostram uma correlação entre origem socioeconômica e percepção sobre o clima escolar. Shukla, Konold e Cornell (2016) encontraram que estudantes afro-americanos com pais menos escolarizados tendiam a ter percepções mais negativas sobre o espaço escolar e De Pedro, Gilreath e Bertowitz (2016) apontaram que os estudantes não-brancos percebiam de forma mais negativa o clima de suas escolas. Esse último estudo assinala que esse resultado pode estar relacionado ao fato de grande parte dos estudantes não-brancos estarem em escolas e distritos com recursos financeiros limitados, o que impactaria o clima das instituições. Esta reflexão também pode ser considerada em nosso estudo, tendo em vista que, no Brasil, as escolas públicas tendem a ter condições financeiras e estruturais inferiores às das escolas privadas.

Um terceiro resultado importante a ser considerado foi a percepção dos alunos, tanto de escolas públicas como de escolas privadas, sobre as situações de bullying no espaço escolar. Em ambas os casos, mais de $69 \%$ dos alunos relataram que já haviam presenciado situações desse tipo em sua escola, um número alto e preocupante considerando os estudos que apontam os efeitos de um espaço escolar hostil para a trajetória dos jovens e crianças. Como discutido ao longo deste trabalho, a presença de bullying e situações de violência no espaço escolar pode trazer prejuízos para desempenho acadêmico dos alunos (MELO e MORAIS, 2019), para a percepção dos jovens sobre a sua instituição (CUNHA, 2014) e para o bem-estar do jovem no ambiente escolar (ALCANTARA et al., 2019). Os dados coletados indicam a necessidade de reflexão dos demais atores escolares sobre a forma como os alunos se relacionam dentro do espaço escolar.

De toda forma, entendemos que conhecer a percepção dos jovens é um primeiro passo que possibilita acessar uma gama de informações sobre os aspectos da vida escolar que podem ajudar a orientar esforços para a melhoria das escolas e, consequentemente, para o prolongamento com sucesso da trajetória escolar dos jovens. Ressaltamos, todavia, que uma das limitações desse estudo é a avaliação do espaço escolar apenas pela visão dos alunos. Acreditamos que, futuramente, seria importante aplicar este instrumento em articulação com questionários dirigidos a outros atores escolares (professores, diretores, coordenadores, famílias) com vistas 
a identificar os diferentes olhares sobre os aspectos que compreendem o ambiente e o clima escolar.

Além dessa limitação, desenvolver uma pesquisa em meio à pandemia COVID 19 foi, sem dúvidas, um dos maiores desafios vividos na construção deste trabalho. Inicialmente planejamos aplicar os questionários presencialmente em três tipos de instituições do Rio de Janeiro, uma pública municipal, uma pública federal e uma instituição privada, contudo, o fechamento das unidades escolares em março/2020 nos obrigou a adaptar as estratégias de pesquisa para o contexto da pandemia. Diante desse imprevisto, buscamos ampliar o campo de pesquisa a fim de viabilizar a coleta de mais respostas e possibilitar a validação empírica do instrumento além de desenvolver um estudo com escolas de diferentes dependências administrativas e em diferentes contextos. $\mathrm{O}$ fato das escolas privadas terem continuado o seu trabalho remotamente e de grande parte das escolas públicas das duas redes de ensino terem praticamente paralisado suas atividades durante meses, resultou em um quantitativo discrepante de respostas de alunos dos dois tipos de dependência administrativa, fato que prejudicou algumas das análises pretendidas inicialmente. A baixa participação dos alunos das duas escolas públicas resultou em uma amostra enviesada desse grupo, já que não sabemos se aqueles que se propuseram a responder ao questionário representam o total de estudantes do $9^{\circ}$ ano das instituições.

Apesar de todos estes limites e desafios, o estudo possibilitou a validação interna e empírica de grande parte do instrumento e possibilitou algumas análises exploratórias que contribuíram para validar o instrumento produzido e apontar caminhos para a realização de outras investigações no futuro.

A primeira sugestão para pesquisas futuras seria aplicar o instrumento a um número maior de respondentes e atores escolares selecionados de forma representativa dos diferentes tipos de redes de ensino, de grupos sociais e de contextos geográficos e políticos. Isso possibilitaria aferir outras percepções sobre os mesmos aspectos e buscar correlações entre construtos presentes em nosso instrumento com outros dados educacionais, como o desempenho e a evasão das instituições escolares, não apenas no ensino médio, mas também nas séries finais do ensino fundamental. Isso possibilitará dimensionar com mais segurança de que modo a mobilização do aluno em relação à escola e à aprendizagem, o clima escolar, a participação discente e a autoeficácia, podem estar relacionados a uma melhora 
nos resultados das instituições e no prolongamento da trajetória escolar dos jovens. Além disso, seria também possível testar correlações estatisticamente significativas entre os diferentes construtos presentes em nosso instrumento, como, por exemplo, buscar compreender melhor as associações entre escolas com bom clima escolar, percepção de autoeficácia dos alunos, participação discente e mobilização em relação à aprendizagem.

Por fim, os depoimentos de alguns jovens participantes da pesquisa, em um espaço destinado a comentários gerais e/ou sugestões sobre o instrumento, mostram como os estudantes conferem importância para momentos que oportunizam e valorizam a visão do aluno, como foi proporcionado por nosso estudo.

"Acho importante que queiram saber como está indo a vida escolar para os alunos" (Aluno da escolar E-Particular/RJ).

"Achei interessante este questionário, gostei bastante de poder dar minhas opiniões e respostas" (Aluno da escola C - Pública/SLZ).

"Achei muito interessante e importante também" (Aluno da escola C Pública/SLZ).

"Gostei do formulário, acho extremamente importante a escola se importar sobre a opinião dos alunos" (Aluno da escola B - Particular/SLZ)

Como visto em nossa revisão bibliográfica, o desejo dos estudantes em atuar mais diretamente no espaço escolar foi manifestado nos movimentos estudantis que ocorreram em 2015 no Brasil, quando os jovens protagonizaram uma luta que revelava as suas vontades de estar à frente das decisões escolares que impactariam as suas trajetórias. Ainda que incipiente, este trabalho pretende ser mais uma contribuição para dar mais visibilidade aos estudantes que, como aponta Claro (2013), apesar de não serem os mais importantes dentre todos os atores escolares, são os protagonistas cujos interesses e direitos devem orientar os processos educativos. Acreditamos que estudos que buscam entender e avaliar o ambiente escolar a partir da visão dos estudantes podem ser importantes ferramentas para a criação de políticas e ações que ajudem a escola a cumprir o seu principal objetivo, de ser eficiente no desenvolvimento integral de todos os sujeitos que recebe. 


\section{8. \\ Referências bibliográficas}

ABAD, M. Crítica política das políticas de juventude. In: FREITAS, M. e PAPA, F. (Org.). Políticas públicas: juventude em pauta. São Paulo: Cortez; Ação Educativa Assessoria, Pesquisa e Informação: Fundação Friedrich Ebert, 2003.

ABRAMO, H. W. Condição juvenil no Brasil Contemporâneo. In: ABRAMO, H; BRANCO, P. P. M Branco (orgs.) Retratos da Juventude Brasileira: análises de uma pesquisa nacional. São Paulo: Editora Fundação Perseu Abramo, 2005. p. 55-72

ABRAMO, H. W. Identidades juvenis: estudo, trabalho e conjugalidade em trajetórias reversíveis. In: Pinheiro et al. (Org.). Agenda juventude Brasil: leituras sobre uma década de mudanças. Rio de Janeiro: Unirio, 2016. p. 19-60.

ABRAMOVAY, M.; CASTRO, M. G.; WAISELFISZ, J.J. Juventudes na escola, sentidos e buscas: Por que frequentam? Brasília: MEC, 2015.

AGUERRE, T. F. Clima organizacional en las escuelas: un enfoque comparativo para Méximo y Uruguay. REICE: Revista Iberoamericana sobre Calidad, Eficacia y Cambio en Educación, v. 14, n. 1696-4713, p. 5-157, 2004.

AGUILLERA, F. Projeto de vida e preparação para a carreira de jovens aprendizes: Da realidade a intervenção. 2013. Tese (Doutorado em Psicologia). Faculdade de Filosofia, Ciências e Letras, Universidade de São Paulo, Ribeirão Preto, 2013.

ALCANTARA, S. C. DE et al. Violência entre pares, clima escolar e contextos de desenvolvimento: suas implicações no bem-estar Peer violence, school environment and developmental contexts: its effects on well-being. Ciência e Saúde Coletiva, v. 24, n. 2, p. 509-522, 2019.

ALVES, C. F. et al. Relações Com a Escola E Expectativas Quanto Ao Futuro Em Jovens Brasileiros. Nuances: estudos sobre Educação, v. 26, n. 1, p. 50-65, 2015.

ANDRADE, S. O Que Fazer No Ano Que Vem? Articulações Entre Juventude, Tempo E Escola. Educação em Revista, v. 33, n. 0, p. 1-26, 2017.

ARELARO, L. R. G.; JACOMINI, M. A.; CARNEIRO, S. R. G. Des limites de participation et gestion "démocratique" aux écoles publiques de l'état de são paulo. Educacao e Sociedade, v. 37, n. 137, p. 1143-1158, 2016.

AZZI, R. G.; COUTO GUERREIRO-CASANOVA, D.; DANTAS, M. A. Autoeficácia acadêmica: possibilidade para refletir o Ensino Médio. Ecc, v. 
12, p. 41-67, 2010.

BANDURA, A. Perceived Self-Efficacy in Cognitive Development and FunctioningEducational Psychologist, 1993.

BANDURA, A. Toward a Psychology of Human Agency. Perspectives on psychological science. v. 1, n. 2, p. 164-190, 2006.

BASTOS, C. Z. DE A. Clima escolar: estudo de caso em uma escola democrática do estado de São Paulo. 2019. 99 f. Dissertação (Mestrado em Educação), Faculdade de Filosofia e Ciênciais, Universidade Estadual Paulista, São Paulo, 2019.

BABBIE, Earl. Métodos de Pesquisas de Survey. Belo Horizonte: Editora UFMG, 2001,. $519 \mathrm{p}$.

BECERRA, S.; MUNOZ, F.; RIQUELME, E. School Violence and School Coexistence Management: Unresolved Challenges. Procedia - Social and Behavioral Sciences, v. 190, n. November 2014, p. 156-163, 2015.

BOURDIEU, P. A juventude é apenas uma palavra. In: BOURDIEU, Pierre. Questões de Sociologia. Rio de Janeiro: Marco Zero, 1983.

BRASIL. Ministério da Educação. Instituto Nacional de Estudos e Pesquisas Educacionais Anísio Teixeira - INEP. Relatório SAEB 2017. Brasília: Inep, 2019a. Disponível em: <http://portal.inep.gov.br/informacao-dapublicacao/-/asset_publisher/6JYIsGMAMkW1/document/id/6730262> acesso em 13 de dez. 2019.

Resumo Técnico: Censo da Educação Básica 2018 [recurso eletrônico]. - Brasília: INEP, 2019. 66 p. Disponível em: <http://download.inep.gov.br/educacao_basica/censo_escolar/resumos_te cnicos/resumo_tecnico_censo_educacao_basica_2018.pdf>. Acesso em 10 dez. 2019.

. Inep divulga dados inéditos sobre fluxo escolar na educação básica. MEC/INEP - Censo Escolar, 20 de junho de 2017. Brasília: Inep, 2019b. Disponível em: <http://portal.inep.gov.br/artigo//asset_publisher/B4AQV9zFY7Bv/content/inep-divulga-dados-ineditossobre-fluxo-escolar-na-educacao-basica/21206> acesso em: 29 jun. 2019.

BRASIL. Lei n. ${ }^{\circ} 12.852$, de 5 de agosto de 2013. Institui o Estatuto da Juventude e dispõe sobre os direitos dos jovens, os principios e diretrizes das políticas de juventude e o Sistema Nacional de Juventude- Sinajuve. Diário Oficial da República Federativa do Brasil, Brasília, DF, 5 de agosto de 2013. Disponível em: http://www.planalto.gov.br/ccivil_03/_ato2011-2014/2013/lei/l12852.htm. Acesso em: 19 jul. 2020.

BRENNER, A. K.; CARRANO, P. C. R. Os sentidos da presença dos jovens no Ensino Médio: representações da escola em três filmes de estudantes. 
Educação \& Sociedade, v. 35, n. 129, p. 1223-1240, 2014.

BRUSCHINI,C. Trabalho doméstico: inatividade econômica ou trabalho não-remunerado? Revista brasileira de estudos de população, v. 23, n.2, p. 331-353, 2006.

BUTZ, A. R.; USHER, E. L. Salient sources of early adolescents' selfefficacy in two domains. Contemporary Educational Psychology, v. 42, p. 49-61, 2015.

CAMARANO et al. Os caminhos para a vida adulta: as múltiplas trajetórias dos jovens brasileiros. Instituto de Pesquisa Econômica Aplicada (IPEA), n. 1038, 2004.

CANDIAN, J. F.; REZENDE, W. S. O contexto normativo do clima escolar e o desempenho dos alunos: implicações para o debate sobre gestão escolar. Revista Pesquisa e Debate em Educação, v. 3, n. 2, p. 24-41, 2013.

CANGUÇU, K. L. A. Estudos Da Associação Entre Clima Escolar E O Desempenho Médio De Alunos Do $5^{\circ}$ Ano Do Ensino Fundamental. 2015. 161 f. Tese (Doutorado em Educaçao) - Faculdade de Educação, Universidade Federal de Minas Gerais, Minas Gerais, 2015.

CARRANO, P. C. R. Juventude e participação no Brasil - interdições e possibilidades. Ibase, v. 30, p. 3-5, 2006.

CATINI, C. DE R.; MELLO, G. M. DE C. Écoles De Combat, Éducation Politique. Educacao e Sociedade, v. 37, n. 137, p. 1177-1202, 2016.

CHARLOT, B. Relação com o saber e com a escola entre estudantes da periferia. Cad. Pesq., v. n.97, p. 47-63, 1996.

CHARLOT, B. A violência na escola: como os sociólogos franceses abordam essa questão. Sociologias, n. 8, p. 432-443, 2002.

CHARLOT, B. A pesquisa educacional entre conhecimentos, políticas e práticas: especificidades e desafios de uma área de saber. Revista Brasileira de Educação, v. 11, n. 31, 2006.

CLARO, J. S. Calidad en educación y clima escolar: apuntes generales. Estudios Pedagogicos. v. 39. $n^{\circ}$ 1: 347-359, 2013.

COELHO, C..; DELL' AGLIO, D. Clima escolar e satisfação com a escola entre adolescentes de ensino médio. Psicologia Teoria e Prática, v. 21, n. 1, p. 248-264, 2019.

COHEN, J. et al. School Climate : Research, Policy, Teacher Education and Practice. Teachers College Record, v. 111, p. 180-213, 2009.

CORTI, A. P..; CORROCHANO, M. C.; SILVA, J. A. Occuper et résister: L'insurrection des étudiants à l'état de são paulo-brésil. Educacao e 
Sociedade, v. 37, n. 137, p. 1159-1176, 2016.

COSTA, B. L. D.; SILVA, C. S. E. Opressão nas escolas : o bullying entre estudantes do ensino básico. Cadernos de Pesquisa, v. 46, n. 161, p. 638-633, 2016.

COUPER M.P; MILLER, P.V. Web surveys methods: introduction. Public Opinion Quarterly, v. 72, n. 5, p. 831-835, 2008.

CUNHA, M. B. Possíveis relações entre percepções de violência dos alunos, clima escolar e eficácia coletiva. Educ. Pesq., v. 40, n. 4, p. 10771092, 2014.

CURI, A. Z.; MENEZES-FILHO, N. A. A relação entre educação préprimária, salários, escolaridade e proficiência escolar no Brasil. Estud. Econ., São Paulo, v. 39, n. 4, 2009.

DAYRELL, J. A escola "faz" as juventudes? Reflexões em torno da socialização juvenil. Educacao e Sociedade, v. 28, n. 100, p. 1105-1128, 2007.

DAYRELL, J.; GOMES, N. L.; LEÃO, G. Escola e participação juvenil: é possível esse diálogo? Educar em Revista, n. 38, p. 237-252, 2010.

DAYRELL, J.; JESUS, R.E. Juventude, ensino médio e os processos de exclusão escolar. Educação e Sociedade. v. 37. n. 135, p. 407-423, 2016. DE PEDRO, K. T.; GILREATH, T.; BERKOWITZ, R. A latent class analysis of school climate among middle and high school students in California public schools. Children and Youth Services Review, v. 63, p. 10-15, 2016.

DIAS, L. A.; SOUSA, R. L. Modos de ser da juventude ocidental. Revista Lumen Et Virtus, v. VI, p. 86-114, 2015.

DOMÉNECH-BETORET, F.; ABELLÁN-ROSELLÓ, L.; GÓMEZ-ARTIGA, A. Self-efficacy, satisfaction, and academic achievement: The mediator role of students' expectancy-value beliefs. Frontiers in Psychology, v. 8, n. JUL, p. 1-12, 2017.

DUARTE, N.; OLIVEIRA, M. E. N. Cultura e clima organizacional de uma escola pública estadual com desempenho satisfatório no Enem. Colloquium Humanarum, v. 14, n. 2, p. 60-74, 2017.

DURKHEIM, É. Educação e sociología. 10. ed. São Paulo: Melhoramentos, 1978.

EL ACHKAR, A. M. N. et al. Risco e proteção de estudantes durante os anos finais do ensino fundamental. Psicologia Escolar e Educacional, v. 21, n. 3, p. 417-426, 2017.

FERRÁNS, S. D. Asociación entre los ambientes escolares y las actitudes de apoyo hacia la violencia en estudiantes colombianos. Revista Colombiana de Educación, n.ํ66, p. 175 - 202, 2014). 
FERRETTI, C. J.; ZIBAS, D. M. L.; TARTUCE, G. L. B. P. Protagonismo juvenil na literatura especializada e na reforma do ensino médio. Cadernos de Pesquisa, v. 34, n. 122, p. 411-423, 2004.

FIELDING, M. Beyond the Rhetoric of Student Voice: new departures or new constraints in the transformation of 21st century schooling? Forum, $v$. 43, n. 2, p. 100, 2001.

FIELDING, M. Transformative approaches to student voice: Theoretical underpinnings, recalcitrant realities. British Educational Research Journal, v. 30, n. 2, p. 295-311, 2004.

FREITAS, P. F.; BATISTA, A. A. G.; MELLO, H. D. A. Juventude(s) e ensino médio: relação dos estudantes com a escola, o saber e as expectativas de futuro em territórios de vulnerabilidade social. Cadernos Cenpec | Nova série, v. 6, n. 2, 2017.

GATTI, BERNADETE A. Estudos quantitativos em educação. Educ. Pesqui., São Paulo, v. 30, n.1, p. 11-30, 2004.

A construção metodológica da pesquisa em educação: desafios. RBPAE, v. 28, n. 1, p. 13-23, jan/abril, 2012.

GIL, Antônio Carlos. Métodos e técnicas de pesquisa social. 6. ed. São Paulo: Atlas, 2008.

GROPPO, L. Juventudes e políticas públicas: comentários sobre as concepções sociológicas de juventude. DESIDADES: Revista Electrónica de Divulgación Científica de la Infancia y la Juventud, v. 14, n. 0, p. 917, 2017.

GROPPO, L. A. Sentidos De Juventude Na Sociologia E Nas Políticas Públicas Do Brasil Contemporâneo. Revista Políticas Públicas, v. 20, n. 1, p. 383, 2016.

GUIMARÃES, N. Trabalho: uma categoria-chave no imaginário juvenil? In: ABRAMO, H; BRANCO, P. P. M Branco (orgs.) Retratos da Juventude Brasileira: análises de uma pesquisa nacional. São Paulo: Editora Fundação Perseu Abramo, 2005. p. 323-350.

HERRERA, P. G.; MORENO, E. O. Autoeficacia académica y rendimiento escolar: Un estudio metodológico y correlacional en escolares. ReiDoCrea: Revista electrónica de investigación y docencia creativa, n. 6, p. 156169, 2017

HOLBROOK, A. L.; GREEN, M. C.; KROSNICK, J.A. Telephone versus face to face interviewing of nationals probability samples with long questionaries. Public Opinion Quarterly, v. 67, n.1, p. 79 - 125, 2003.

HUANG, T.; HOCHBEIN, C.; SIMONS, J. The relationship among school contexts, principal time use, school climate, and student achievement. 
Educational Management Administration and Leadership, v. 48, n. 2, p. 305-323, 2020.

IAOCHITE, R. T. et al. Autoeficácia no campo educacional: revisão das publicações em periódicos brasileiros. Psicologia Escolar e Educacional, v. 20, n. 1, p. 45-54, 2016.

IBGE. Instituto Brasileiro de Geografia e Estatística. Pesquisa Nacional por Amostra de Domicílios (PNAD) 2020. Disponível em: https://www.ibge.gov.br/. Acesso em: 09 de janeiro de 2020.

JONES, M. A.; BUBB, S. Student voice to improve schools: Perspectives from students, teachers and leaders in 'perfect' conditions. Improving Schools, n. 2014, p. 1-21, 2020.

KANE, R. G.; CHIMWAYANGE, C. Teacher action research and student voice: Making sense of learning in secondary school. Action Research, v. 12, n. 1, p. 52-77, 2014.

KIRK, C. M. et al. The Empowering Schools Project: Identifying the Classroom and School Characteristics That Lead to Student Empowerment. Youth and Society, v. 49, n. 6, p. 827-847, 2017.

KLEIN, J.; CORNELL, D.; KONOLD, T. Relationships between Bullying School Climate and Student Risk Behaviors. School Psychology Quarterly, v. 3, p. 154-169, 2012.

KRISCHKE, P.J. Questões sobre juventude, cultura política e participação democrática. In: ABRAMO, H; BRANCO, P. P. M Branco (orgs.) Retratos da Juventude Brasileira: análises de uma pesquisa nacional. São Paulo: Editora Fundação Perseu Abramo, 2005. p. 323-350.

LEAL, M. DE S.; MELO-SILVA, L. L.; TEIXEIRA, M. O. Crenças para lidar com tarefas de carreira em estudantes do ensino médio. Avaliacao Psicologica, v. 14, n. 1, p. 125-132, 2015.

LEÃO, G.; DE ARAÚJO SANTOS, T. N. Youth participation in the Brazilian High School: An ongoing field studies. Praxis Educativa, v. 13, n. 3, p. 787-804, 2018.

LEEK, J. Teachers perceptions about supporting youth participation in schools: Experiences from schools in England, Italy and Lithuania. Improving Schools, v. 22, n. 2, p. 173-190, 2019.

LONGO, F. V.; VIEIRA, J. M. Educação de mãe para filho: fatores associados à mobilidade educacional no Brasil. Educ. Soc, v. 38, n. 141, p. $1051-1071,2017$.

MACNEIL, A. J.; PRATER, D. L.; BUSCH, S. International Journal of Leadership in Education: Theory and Practice The effects of school culture and climate on student achievement. International Journal of Leadership 
in Education: Theory and Practice, v. 12, n. December 2014, p. 73-84, 2009.

MAGER, U.; NOWAK, P. Effects of student participation in decision making at school. A systematic review and synthesis of empirical research. Educational Research Review, v. 7, n. 1, p. 38-61, 2012.

MANGANELLI, S.; LUCIDI, F.; ALIVERNINI, F. Italian adolescents' civic engagement and open classroom climate: The mediating role of selfefficacy. Journal of Applied Developmental Psychology, v. 41, p. 8-18, 2015.

MARTINS, F. A. S.; DAYRELL, J. T. Juventude e participação: o grêmio estudantil como espaço educativo. Educação \& Realidade, v. 38, n. 4, p. 1267-1282, 2013.

MATA, L. et al. Emoções em contexto académico: Relações com clima de sala de aula, autoconceito e resultados escolares. Analise Psicologica, v. 33, n. 4, p. 407-424, 2015.

MELO, S. G. DE. Relações entre clima escolar e desempenho acadêmico em escolas públicas de ensino médio representativs de um estado brasileiro. 2017. 260 f. Tese (Doutorado em Educação), Faculdade de Educação - Universidade Estadual Paulista, São Paulo, 2017.

MELO, S. G. DE; MORAIS, A. DE. Clima Escolar Como Fator Protetivo Ao Desempenho Em Condições Socioeconômicas Desfavoráveis. Cadernos de Pesquisa, v. 49, n. 172, p. 10-34, 2019.

MITRA, D. L.; GROSS, S. J. Increasing student voice in high school reform: Building partnerships, improving outcomes. Educational Management Administration and Leadership, v. 37, n. 4, p. 522-543, 2009.

MITRA, D.; SERRIERE, S.; STOICOVY, D. The role of leaders in enabling student voice. Management in Education, v. 26, n. 3, p. 104-112, 2012. NOVAES, R.; VENTURI, G. Introdução. In: PINHEIRO, D. et al. (orgs). Agenda Juventude Brasil. Rio de Janeiro: UniRio, 2016, p. 6-9.

OCDE (Organização para a Cooperação e Desenvolvimento Econômico). Os estudantes alcançam melhores desempenhos nas escolas em que há mais disicplina? Boletim Pisa em Foco, n.32, p. 1-3, 2013. Disponível em: https://www.institutounibanco.org.br/aprendizagem-em foco/4/tablet/index.html. Acesso em: 15 de dezembro de 2020.

OLIVEIRA, M. B.; SOARES, A. B. Auto-eficácia, raciocínio verbal e desempenho escolar em estudantes. Psicologia: Teoria e Pesquisa, v. 27, n. 1, p. 33-39, 2011.

OLIVEIRA, A. C. P. As relações entre Direção, Liderança e Clima Escolar em escolas municipais do Rio de Janeiro. 2015. $284 \mathrm{f}$. Tese (Doutorado em Educação) - Faculdade de Educação, Pontifícia Universidade Católica do Rio de Janeiro, Rio de Janeiro, 2015. 
OLIVEIRA, R. P. DE; ARAUJO, G. C. Qualidade do ensino: uma nova dimensão da luta pelo direito à educação. Revista Brasileira de Educação, n. 28, p. 5-23, 2005.

ORPINAS, P.; RACZYNSKI, K. School Climate Associated with School Dropout Among Tenth Graders. Pensamiento Psicológico, v. 14, n. 1, p. 9-20, 2016.

PAIS, J. M. A construção sociológica da juventude. Alguns contributos. Análise Social, v. XXV, p. 139-165, 1990.

PAIS, J. M. Culturas juvenis. Lisboa: Imprensa Nacional/ Casa da Moeda. 1993.

PEREIRA, B. P.; LOPES, R. E. Por que ir à Escola? Os sentidos atribuídos pelos jovens do ensino médio. Educação \& Realidade, v. 41, n. 1, p. 193216, 2016.

QUIN, J. L. et al. The correlation between leadership, culture, and student achievement. Turkish Online Journal of Educational Technology, v. 2015, n. 2, p. 573-579, 2015.

RAMOS, E. S. DA S.; SALVA, S. Eu não me dava muito bem com a escola: um estudo com jovens do ensino médio - I do not gave very well with school: a study with young middle school. Revista de Gestão e Avaliação Educacional, v. 3, n. 6, p. 17-26, 2014.

REIS, R. R. DOS. Juventude e Conhecimento Escolar: um estudo sobre o (Des)interesse. [s.I.] Pontifícia Universidade Católica de Sao Paulo, 2014.

REZENDE, W. S.; CANDIAN, J. F. Uma Exploração das Relações Entre Clima, Desempenho e Gestão Escolar no Proeb 2010. VII Reunião Abave: Avaliação e Currículo: um diálogo necessário, 2013.

RIBEIRO, E. A. A perspectiva da entrevista na investigação qualitativa. Evidência: Olhares e pesquisas em Saberes Educacionais, n. 4, p. 129148, 2008.

ROBINSON, C.; TAYLOR, C. Theorizing student voice: Values and perspectives. Improving Schools, v. 10, n. 1, p. 5-17, 2007.

ROBINSON, C.; TAYLOR, C. Student voice as a contested practice: Power and participation in two student voice projects. Improving Schools, v. 16, n. 1, p. 32-46, 2013.

ROMANCINI, R.; CASTILHO, F. "Como ocupar uma escola? Pesquiso na Internet!": política participativa nas ocupações de escolas públicas no Brasil. Intercom: Revista Brasileira de Ciências da Comunicação, v. 40, n. 2, p. 93-110, 2017. 
RUTTER, $M$ et al. Fifteen Thousand Hours: Secundary Schools ans their Effects on Children. London: Open Books; Cambridge: Harvard University Press, 1979.

SANTOS, R. M. DOS; NASCIMENTO, M. A.; MENEZES, J. DE A. Os sentidos da escola pública para jovens pobres da cidade do Recife. Revista Latinoamericana de Ciencias Sociales, Niñez y Juventud, v. 10, p. 289300, 2012.

SOARES, J. F. Índice de desenvolvimento da educação de São Paulo IDESP: bases metodológicas. São Paulo em Perspectiva, São Paulo, v. 23, n. 1, p. 29-41, jan./jun. 2009.

SOUZA, A. R. Explorando e construindo um conceito de gestão escolar democrática. Educação em Revista. Belo Horizonte, v.25, n.3, p.123-140, dez. 2009.

SHUKLA, K.; KONOLD, T.; CORNELL, D. Profiles of Student Perceptions of School Climate: Relations with Risk Behaviors and Academic Outcomes. American Journal of Community Psychology, p. 291-307, 2016.

SPOSITO, M. P.; SOUZA, R.; SILVA, F. A. E. A pesquisa sobre jovens no Brasil: traçando novos desafios a partir de dados quantitativos. Educação e Pesquisa, v. 44, n. 0, p. 1-24, 2017.

STOSKI, P.; GELBCKE, V.R. Juventudes e escolas: os distanciamentos e as aproximações entre os jovens e o Ensino Médio. In: SILVA, M.R; OLIVEIRA, R.G. (Orgs.) Juventude e Ensino Médio: sentidos e significados da experiência escolar. Curitiba: UFPR/Setor de Educação, 2016. p. 33-52.

THAPA, A. et al. A Review of School Climate Research. Review of Educational Research, v. 83, n. 3, p. 357-385, 2013.

THOMPSON, P. Consulting secondary school pupils about their learning. Oxford Review of Education, v. 35, n. 6, p. 671-687, 2009.

TOMAZETTI, E. M. et al. Escola, ensino médio e juventude: a massificação de um sistema e a busca de sentido. Educação e Pesquisa, v. 42, n. 2, p. 331-342, 2016.

VENDRAMINI, C. R. et al. Escola, trabalho e perspectiva de futuro de jovens estudantes. Revista ibero-americana de estudos em educação, v. 12, n. 4, p. 2155-2176, 2017.

VINHA, T. P. et al. O clima escolar na perspectiva dos alunos de escolas públicas. Revista Educação e Cultura Contemporânea, v. 15, n. 40, p. 163-186, 2017. 
ZIBAS, D. M. L.; FERRETTI, C. J.; TARTUCE, G. L. B. P. Micropolítica escolar e estratégias para o desenvolvimento do protagonismo juvenil. Cadernos de Pesquisa, v. 36, n. 127, p. 51-85, 2006.

ZULLIG, K. J. et al. School climate: Historical review, instrument development, and school assessment. Journal of Psychoeducational Assessment, v. 28, n. 2, p. 139-152, 2010. 


\section{APÊNDICES}


Apêndice A

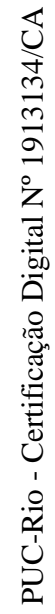


PUC

Prezado/a estudante:

- Você está participando de uma pesquisa para a universidade.

- Este questionário não é uma prova.

- Não existe resposta certa ou errada.

- Responda de acordo com o que você pensa.

- Caso tenha dúvida, você pode perguntar.

1 Nome da Escola:
Pense nos motivos pelos quais você vai à escola. Marque qual é o seu nivel de concordância com cada uma das afir- $\begin{aligned} & \text { Discordo } \\ & \text { totalmente }\end{aligned} \longleftrightarrow \begin{gathered}\text { Concordo } \\ \text { totalmente }\end{gathered}$ mativas abaixo:

4.1. Vou à escola porque sou obrigado.

4.2. Vou à escola porque é meu direito

4.3. Vou à escola porque gosto de aprender.

4.4. Vou à escola porque me interesso por alguma disciplina

4.5. Vou à escola porque gosto dos professores.

4.6. Vou à escola porque acho importante para conseguir um trabalho futuramente.

(1) (2) (3) (4)

(1) (2) (3) (4)

(1) (2) (3) (4)

(1) (2) (3) (4)

(1) (2) (3) (4)

(1) (2) (3) (4)

4.7. Vou à escola para tentar entrar na faculdade/ensino superior.

(1) (2) (3) (4)

4 lou à escola para ter uma melhores condições de vida do

$\varangle$ lue meus pais/responsáveis.

$4 \bigcup 1$ lou à escola para fazer amigos.

$4 \frac{f}{7}$ Vou à escola porque gosto do intervalo/recreio

5 m. sua opinião, qual o grau de importância do que você

rende na escola nos seguintes aspectos da sua vida:

$\mathbf{5}$ Z ara o meu futuro profissional

5.. t.

$5 \cdot \frac{0}{a}$ tara as coisas que faço no dia a dia.

$5, \mathcal{0}$ tara fazer amigos.

5 巳

Jela ciência

5 s tara conviver melhor em sociedade.

6 ' nse na escola em que você estuda. Marque qual é

- seu nivel de concordância com cada uma das afir-

' ativas abaixo:

6 osto de estudar na minha escola.

6.2. A minha escola oferece um ambiente favorável para todos aprenderem.

(1) (2) (3) (4) (1) (2) (3) (4) (1) (2) (3) (4)

Nada
Importante Muito

(1) (2) (3) (4)

(1) (2) (3) (4)

(1) (2) (3) (4)

(1) (2) (3) (4)

(1) (2) (3) (4)

(1) (2) (3) (4)

Discordo
totolmente $\begin{gathered}\text { Concordo } \\ \text { totolmente }\end{gathered}$

(1) (2) (3) (4)

(1) (2) (3) (4)

6.3. Na minha escola, as salas de aula são confortáveis, limpas e conservadas.

6.4. Na minha escola, há uma biblioteca com livros variados.

6.5. Na minha escola, os espaços utilizados durante o intervalo e para a convivência săo adequados.

(1) (2) (3) (4)

(1) (2) (3) (4)

(1) (2) (3) (4)

6.6. Na minha escola, nunca presenciei situações de discriminação.

(1) (2) (3) (4)

6.7. Na minha escola, nunca presenciei situações de bullying

6.8. Na minha escola, os alunos respeitam e valorizam os professores.

(1) (2) (3) (4)

(1) (2) (3) (4)

6.9. Na minha escola, sinto que todos estcóo atentos às minhas necessidades

(1) (2) (3) (4)

6.10. Na minha escola, sinto que sou valorizado por todos.

6.11. Tenho orgulho de ser aluno da minha escola.

(1) (2) (3) (4)

(1) (2) (3) (4)

6.12. Na minha escola, as regras são claras para todos os alunos.

(1) (2) (3) (4)

6.13. Na minha escola, as regras são justas.

(1) (2) (3) (4)

6.14. Na minha escola, as consequências para aqueles que quebram as regras são justas.
Turma:

Data do preenchimento:

7 Marque a opção que melhor expressa como você avalia sua relaçāo com:

7.1. Os professores.

7.2. 0 diretor(a).

7.3. A coordenaçăo

7.4. Os funcionários da escola

7.5. Os colegas de turma.

7.6. Os outros alunos da escola.

8 Considerando a maioria das suas aulas, indique sua escola.

8.1. Os alunos não escutam o que os professores (1) (2) (3) (4) dizem.

(1) (2) (3) (4)

8.2. Há desordem e confusão na sala de aula.

(1) (2) (3) (4) (5) (6)

(1) (2) (3) (4) (5) (6)

(1) (2) (3) (4) (5) (6)

(1) (2) (3) (4) (5) (6)

(1) (2) (3) (4) (5) (6)

(1) (2) (3) (4) (5) (6)

8.3. Os professores precisam esperar um longo tempo para os alunos ficarem em silêncio.

(1) (2) (3) (4)

8.4. Os professores mostram interessenoaprendizado de todos os alunos.

(1) (2) (3) (4)

8.5. Os professores mandam deveres de casa.

(1) (2) (3) (4)

8.6. Os professores corrigem os deveres de casa.

(1) (2) (3) (4)

8.7. Os professores oferecem ajuda extra para todos os alunos com dificuldade de aprender.

(1) (2) (3) (4)

8.8. Os professores fazem perguntas para saber se os (1) (2) (3) (4) alunos entenderam o que foi ensinado.

8.9. Os professores me falam como eu posso melhorar (1) (2) (3) (4) meu desempenho escolar.

8.10. Os professores encorajam os alunos a expressarem a sua opinião sobre os temas (1) (2) (3) (4) estudados.

8.11. Os professores apoiam e incentivam os alunos a (1) (2) (3) (4) participarem ativamente.

9. A sua escola possui grêmio estudantil ou outra forma de representação (1) Não estudantil?

10 Você acha que os alunos devem participar das decisões da escola que (1) Nấo dizem respeito aos estudantes?

11 Em relação à sua participação nas decisões da escola que dizem respeito aos alunos, você..

(1) Acho que participo o suficiente.

(2) Participo, mas gostaria de participar mais.

(3) Não participo, mas gostaria de participar 
12 Indique a frequência com que estas coisas acontecem em sua escola.

Nunca Raramente $\begin{gathered}\text { Algumas } \\ \text { vezes }\end{gathered}$ Frequente-

12.1. Os alunos são convidados a darem as suas opiniöes sobre o que é melhor para a turma ou para a escola

(1)

(1)

(2) (3)

(4)

pelos professores, coordenadores e diretor(a).

12.3. Osalunos sentemque assuas opinióes são consideradas pelos professores, coordenadores e diretor(a).

(1) (2) (3) (4)

(2) (3)

(4)

12.4. Os alunos participam da elaboraçáo e das mudanças das regras da escola.

(1) (2) (3) (4)

12.5. Os alunos são incentivados a participarem de acōes fora da escola (projetos sociais, trabalhos em ONGs, movimentos sociais)

\section{(1)}

(2)

(3)

(4)

\begin{tabular}{|c|c|c|c|c|}
\hline 13 Indique em que medida você se sente capaz de: & $\begin{array}{l}\text { Não me } \\
\text { Sinto } \\
\text { capaz }\end{array}$ & $\begin{array}{l}\text { Me sinto } \\
\text { pouco } \\
\text { capaz }\end{array}$ & $\begin{array}{l}\text { Me sinto } \\
\text { razoa- } \\
\text { velmente } \\
\text { capaz }\end{array}$ & $\begin{array}{c}\text { Me sinto } \\
\text { plena- } \\
\text { mente } \\
\text { capaz }\end{array}$ \\
\hline 13.1. Concluir o Ensino Médio. & (1) & (2) & (3) & (4) \\
\hline 13.2. Ingressar no Ensino Superior. & (1) & (2) & (3) & (4) \\
\hline 13.3. Obter bons resultados nas avaliaçōes. & (1) & (2) & (3) & (4) \\
\hline 13.4. Conseguir um bom emprego no futuro. & (1) & (2) & (3) & (4) \\
\hline $\begin{array}{l}\text { 13.5. Ajudar os colegas quando estáo com dificuldade em } \\
\text { algum conteúdo. }\end{array}$ & (1) & (2) & (3) & (4) \\
\hline 13.6. Contribuir com a harmonia em sala de aula. & (1) & (2) & (3) & (4) \\
\hline $\begin{array}{l}\text { : Pensar em soluçóes para problemas que estejam } \\
\text { acontecendo na escola. }\end{array}$ & (1) & (2) & (3) & (4) \\
\hline
\end{tabular}

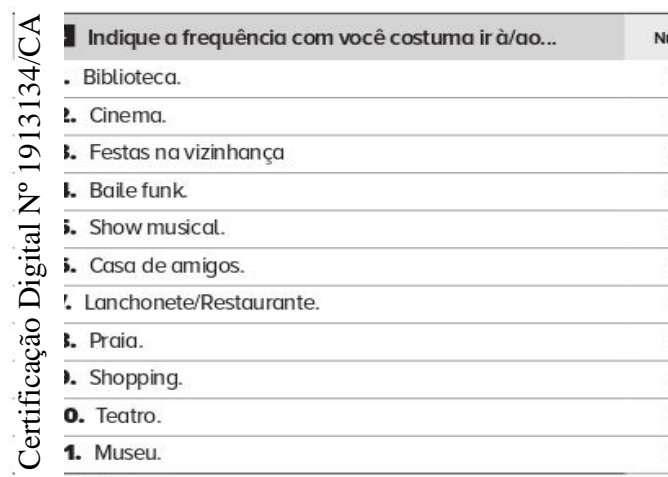

2. Parques.

$\frac{0}{2}$

官

Indique a frequência com que você lê:

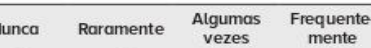

(1) (2) (3)

(1) (2) (3)

(1) (2) (3)

(1) (2) (3)

(1) (2) (3)

(1) (2) (3)

(1) (2) (3)

(1) (2) (3)

(1) (2) (3)

(1) (2) (3)

(1) (2) (3)

(1) (2) (3)

(1) (2)

(2) (3)

Nunca Raramente $\begin{gathered}\text { Algumas } \\ \text { vezes }\end{gathered} \begin{gathered}\text { Frequente- } \\ \text { mente }\end{gathered}$

(1) (2)

(2) (3)

(1) (2) (3)

(1) (2) (3)

(1) (2) (3)

(1)

(2) (3)

(4)

(4)

(4)

(4)

(4)

(4)

(4)

(4)

(4)

(4)

(4)

(4)

(4)

(4)

(4)

(4)

15.4. Notícias sobre esportes

15.5. Livros em geral

(1) $\operatorname{sim}$

(2) Não

26 Qual o seu sexo? um tempo e depois voltou a se matricular?

sua casa

28 Qual a sua cor ou raça?

(1) Branca.

(2) Preta.

(3) Parda.

(4) Amarela.

(5) Indígena.

(6) Prefiro não declarar.
29 Marque os itens que você possui na sua casa Não Sim

29.2. Um quarto só para você

29.3. Um lugar silencioso para estudar.

29.4. Um computador que você pode usar para fazer trabalhos da escola.

29.5. Internet.

29.6. Livros de literatura clássica.
29.1. Uma mesa para estudar.
(1) (2)

(1) (2)

(1) (2)

(1) (2)

(1) (2)

(1) (2)
16 Você participa de:

(marque todas que se aplicam ou nenhuma alternativa)

(1) Organização SociaV Não governamental (ex. ONGs)

(2) Coletivo (feminista, LGBTQ, negro ou outro).

(3) Movimento Estudantil.

(4) Partido político.

(5) Grupo religioso.

17 Em dias de aula, quanto tempo você gasta assistindo TV, navegando na internet ou jogando jogos eletrônicos?

(1) Menos de uma hora.

(2) Entre 1 e 2 horas.

(3) Mais de duas horas, até 3 horas.

(4) Mais de 3 horas.

(5) Não vejo tv, não navego na internet e não jogo jogos eletrônicos.

$18 \mathrm{Em}$ dias de aula, quanto tempo você gasta fazendo trabalhos domésticos? (ex. lavando louça, limpando o quintal, etc.)?

(1) Menos de uma hora.

(2) Entre 1 e 2 horas.

(3) Mais de 2 horas, até 3 horas.

(4) Mais de 3 horas.

(5) Não faço trabalhos domésticos.

19 Atualmente você trabalha fora de casa (recebendo ou (1) Sim não salário)?

(2) Não

20 Quando você terminar o $9^{\circ}$ ano, o que você pretende fazer?

(1) Somente continuar estudando.

(2) Somente trabalhar.

(3) Continuar estudando e trabalhar.

(4) Ainda não sei.

21 Daqui a 5 anos, você se imagina cursando o ensino (1) Sim superior?

(2) Não

22 Quando você começou a ir à escola?

(1) Na creche ( 0 a 3 anos).

(2) Na pré-escola (4 a 5 anos)

(3) Na primeira série ou primeiro ano (6 a 7 anos).

(4) Depois da primeira série ou primeiro ano.

23 A partir do sexto ano, em que tipo de escola você estudou?

(1) Somente escola pública municipal.

(2) Somente escola pública federal.

(3) Somente escola particular.

(4) Em escola pública e em escola particular.

(1) F 27 Informe, por favor, seu mês e ano de aniversário.

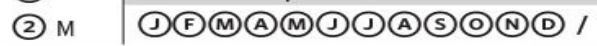

29 Marque os itens que você possui na sua casa Não Sim

29.7. Livros de poesía.

29.8. Trabalhos artísticos (ex. quadros, esculturas)

29.9. Livros que ajudam você nos trabalhos da escola. (1) (2)

29.10. Dicionário. (1) (2)

29.12. Televisão. (1) (2)

29.12 Máquina de lavar roupa. (1) (2)

29.13. Carro. (1) (2) 


\section{GESC}

PESOUISA: JOVENS E ESCOLAS: QUAIS AS RELAÇÕES?

\section{Quantos livros você tem na sua casa?}

(1) 0-10 livros.

(2) 11-25 livros.

(3) $26-100$ livros.

(4) $101-200$ livros.

(5) 201-500 livros

(6) Mais de 500 livros.
31 Até que série sua mãe, ou mulher responsável por você estudou?

(1) Nunca estudou.

(2) Náo completou a $4^{\text {a }}$ série $/ 5^{\circ}$ ano do Ensino Fundamental.

(3) Completou a $8^{\mathrm{a}}$ série $/ 9^{\circ}$ ano do Ensino Fundamental, mas não completou o Ensino Médio.

(4) Completou o Ensino Médio, mas não completou Faculdade.

(5) Completou a faculdade.

(6) Não sei. Até que série seu pai, ou homem responsável por você estudou?

(1) Nunca estudou.

(2) Não completou a $4^{\text {a }}$ série $/ 5^{\circ}$ ano do Ensino Fundamental.

(3) Completou a $8^{\mathrm{a}}$ série $/ 9^{\circ}$ ano do Ensino Fundamental, mas não completou o Ensino Médio.

(4) Completou o Ensino Médio, mas não completou a Faculdade.

(5) Completou a faculdade.

(6) Não sei.

3 3 Nosso questionário chegou ao fim! Agradecemos a sua participação. Caso queira registrar algum comentário sobre este questionário ou acrescentar alguma informação que julgue importante, utilize o espaço abaixo:

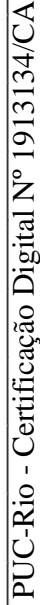




\section{Apêndice B}

1) Índice de percepção dos alunos sobre as relações interpessoais no espaço escolar.

Quadro 8 - Índice de percepção dos alunos sobre as relações interpessoais no espaço escolar.

\begin{tabular}{|l|c|}
\hline \multicolumn{2}{|l|}{ Índice de percepção dos alunos sobre as relações interpessoais } \\
\hline Variável & Carga Fatorial \\
\hline $\begin{array}{l}\text { Pense na escola em que você estuda. Marque qual é o seu nível } \\
\text { de concordância com cada uma das afirmativas abaixo: Na } \\
\text { minha escola, os alunos respeitam e valorizam os professores. }\end{array}$ & 0,349 \\
\hline $\begin{array}{l}\text { Marque a opção que melhor expressa como você avalia sua } \\
\text { relação com... os professores. }\end{array}$ & 0,503 \\
\hline $\begin{array}{l}\text { Marque a opção que melhor expressa como você avalia sua } \\
\text { relação com... o(a) diretor(a). }\end{array}$ & 0,473 \\
\hline $\begin{array}{l}\text { Marque a opção que melhor expressa como você avalia sua } \\
\text { relação com... a coordenação. }\end{array}$ & 0,671 \\
\hline $\begin{array}{l}\text { Marque a opção que melhor expressa como você avalia sua } \\
\text { relação com... os funcionários da escola. }\end{array}$ & 0,291 \\
\hline $\begin{array}{l}\text { Marque a opção que melhor expressa como você avalia sua } \\
\text { relação com... os colegas de turma. }\end{array}$ & 0,548 \\
\hline $\begin{array}{l}\text { Marque a opção que melhor expressa como você avalia sua } \\
\text { relação com... os outros alunos da escola }\end{array}$ & 0,661 \\
\hline Alpha de cronbach: $\mathbf{0 , 5 1 5}$ & \\
\hline KMO: 0, 622 & \\
\hline
\end{tabular}

Nota: Extraído pelo método de Análise de Componentes Principais (PCA). Fonte: Questionário "Jovens e escolas: quais as relações?". Elaborado pela autora.

2) Índice de percepção dos alunos sobre a segurança física e emocional na escola.

Quadro 9 - Índice de percepção dos alunos sobre a segurança física e emocional na escola.

\begin{tabular}{|l|c|}
\hline Índice de percepção dos alunos sobre a segurança física e emocional na escola \\
\hline Variável & Carga Fatorial \\
\hline $\begin{array}{l}\text { Marque a opção que melhor expressa como você avalia sua } \\
\text { relação com... os professores. }\end{array}$ & 0,911 \\
\hline $\begin{array}{l}\text { Marque a opção que melhor expressa como você avalia sua } \\
\text { relação com... o(a) diretor(a). }\end{array}$ & 0,911 \\
\hline Alpha de cronbach: $\mathbf{0 , 7 9 6}$ & \\
\hline KMO: 0,500
\end{tabular}

Nota: Extraído pelo método de Análise de Componentes Principais (PCA). Fonte: Questionário

"Jovens e escolas: quais as relações?". Elaborado pela autora. 


\section{Apêndice C}

Quadro 10: Valores para categorização do Índice de mobilização em relação à escola.

\begin{tabular}{|l|c|c|c|}
\hline & $\begin{array}{c}\text { Baixa } \\
\text { mobilização }\end{array}$ & $\begin{array}{c}\text { Média } \\
\text { mobilização }\end{array}$ & $\begin{array}{c}\text { Alta } \\
\text { mobilização }\end{array}$ \\
\hline $\begin{array}{l}\text { Mobilização } \\
\text { para projetos } \\
\text { futuros }\end{array}$ & 4,00 a 6,00 & 7,00 até 10,00 & 11,00 até 12,00 \\
\hline $\begin{array}{l}\text { Mobilização } \\
\text { para a } \\
\text { Sociabilidade }\end{array}$ & 2,00 a 3,00 & 4,00 a 6,00 & 7,00 a 8,00 \\
\hline
\end{tabular}

Elaboração própria

Quadro 11: Valores para categorização das dimensões do Clima Escolar

\begin{tabular}{|c|c|c|c|}
\hline & Ruim & Intermediária & Boa \\
\hline Infraestrutura & 5,00 a 8,00 & 9,00 a 13,00 & 14,00 a 16,00 \\
\hline $\begin{array}{l}\text { Apoio do } \\
\text { professor }\end{array}$ & 9,00 a 16,00 & 17,00 a 23,00 & 24,00 a 28,00 \\
\hline Indisciplina & 3,00 a 5,00 & 6,00 a 9,00 & 10,00 a 12,00 \\
\hline $\begin{array}{l}\text { Clareza e Justiça } \\
\text { das regras }\end{array}$ & 4,00 a 7,00 & 8,00 a 12,00 & 13,00 a 16,00 \\
\hline & Baixo & Médio & Alto \\
\hline Pertencimento & 4,00 a 7,00 & 8,00 a 12,00 & 13,00 a 16,00 \\
\hline
\end{tabular}

Elaboração própria

Quadro 12: Valores para categorização da percepção dos alunos sobre a participação discente no espaço escolar.

\begin{tabular}{|l|c|c|c|}
\hline & Baixa & Média & Alta \\
\hline Participação & 4,00 a 7,00 & 8,00 até 12,00 & 13,00 até 16,00 \\
\hline
\end{tabular}

Quadro 13: Valores para categorização das crenças de autoeficácia do jovens.

\begin{tabular}{|l|c|c|c|}
\hline & Baixa & Média & Alta \\
\hline Autoeficácia & 6,00 a 9,00 & 10,00 a 13,00 & 14,00 a 16,00 \\
\hline
\end{tabular}




\section{APÊNDICE C}

Quadro 14 - Respostas do item "Na sua opinião qual o grau de importância do que você aprende por dependência administrativa.

\begin{tabular}{|c|c|c|c|c|c|c|c|c|}
\hline \multicolumn{5}{|c|}{ Escolas Públicas } & \multicolumn{4}{|c|}{ Escolas Particulares } \\
\hline & $\begin{array}{c}\text { Nada } \\
\text { importante }\end{array}$ & $\begin{array}{c}\text { Pouco } \\
\text { importante }\end{array}$ & $\begin{array}{c}\text { Mais ou } \\
\text { menos } \\
\text { importante }\end{array}$ & $\begin{array}{c}\text { Muito } \\
\text { importante }\end{array}$ & $\begin{array}{c}\text { Nada } \\
\text { importante }\end{array}$ & $\begin{array}{c}\text { Pouco } \\
\text { importante }\end{array}$ & $\begin{array}{c}\text { Mais ou } \\
\text { menos } \\
\text { importante }\end{array}$ & $\begin{array}{c}\text { Muito } \\
\text { importante }\end{array}$ \\
\hline $\begin{array}{l}\text { Para o meu } \\
\text { futuro } \\
\text { profissional }\end{array}$ & $1,1 \%$ & $2,7 \%$ & $23,4 \%$ & $72,8 \%$ & $0 \%$ & $0 \%$ & $10 \%$ & $90 \%$ \\
\hline $\begin{array}{l}\text { Para } \\
\text { compreender } \\
\text { a realidade do } \\
\text { mundo } \\
\end{array}$ & $2,2 \%$ & $7,6 \%$ & $33,2 \%$ & $57,1 \%$ & $0 \%$ & $0 \%$ & $45 \%$ & $55 \%$ \\
\hline $\begin{array}{l}\text { Para fazer } \\
\text { amigos }\end{array}$ & $7,6 \%$ & $19,0 \%$ & $28,8 \%$ & $44,6 \%$ & $7,50 \%$ & $32,50 \%$ & $45 \%$ & $15 \%$ \\
\hline $\begin{array}{l}\text { Para as coisas } \\
\text { que faço no } \\
\text { dia a dia }\end{array}$ & $12,0 \%$ & $24,5 \%$ & $39,1 \%$ & $24,5 \%$ & $0 \%$ & $20 \%$ & $50 \%$ & $30 \%$ \\
\hline 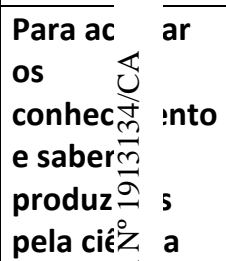 & $2,7 \%$ & $8,2 \%$ & $34,2 \%$ & $54,9 \%$ & $0,00 \%$ & $5,00 \%$ & $22,5 \%$ & $73 \%$ \\
\hline 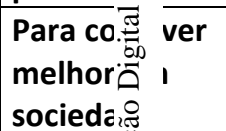 & $5,4 \%$ & $5,4 \%$ & $28,8 \%$ & $60,3 \%$ & $0,00 \%$ & $2,50 \%$ & $33 \%$ & $65 \%$ \\
\hline
\end{tabular}

Elaboração própria 


\section{Apêndice D}

\section{TERMOS DE ASSENTIMENTO E CONSENTIMENTO - PRÉ-TESTE}

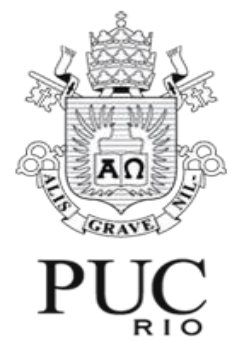

\section{TERMO DE ASSENTIMENTO LIVRE E}

\section{ESCLARECIDO}

Prezado, aluno (a).

Você está sendo convidado(a) como voluntário(a) a participar da pesquisa "Jovens e escolas: quais as relações?"

Neste estudo pretendemos compreender as relações que os jovens estabelecem com a escola e o seu processo de escolarização.

Sua colaboração será necessária na $6^{a}$ etapa dessa pesquisa, quando aplicaremos um questionário que aborda questões acerca da sua escola (sua percepção sobre a instituição, como avalia alguns aspectos desse estabelecimento, qual o nível participação discente, entre outros), sua trajetória escolar (com quantos anos entrou na escola, quais espaços utiliza nesse estabelecimento etc.) e sobre seus hábitos enquanto jovem (o que gosta de fazer, se faz parte de algum coletivo, entre outros). Depois faremos uma entrevista para saber o que achou do questionário. Essa entrevista será coletiva com você e mais 3 ou 4 alunos da sua turma. Será feita na sua escola, com a autorização da sua professora e dos seus pais, terá a minha presença e de mais uma pesquisadora e será gravada em áudio. Garantimos que a sua identidade não será revelada a ninguém e que somente nós, pesquisadores, teremos acesso aos áudios.

A qualquer momento, você poderá tirar dúvidas ou encerrar sua participação na pesquisa. Caso você se sinta incomodado ou envergonhado durante a entrevista, peço que fale comigo para que possamos te ajudar. No entanto, achamos que essa será uma experiência interessante, já que você terá espaço para refletir e dar a sua opinião sobre a sua participação dentro da sua escola.

Lembramos que a sua colaboração é voluntária e se você não quiser participar, não terá nenhuma consequência em casa ou na escola.

Além disso, durante a pesquisa e até um ano após o seu término, você poderá solicitar mais informações sobre o estudo ou cópias dos materiais divulgados, entrando em contato através do e-mail: manuelagrill_@hotmail.com ou através do telefone (21) 98505-4759. O material da pesquisa ficará sob a guarda da pesquisadora (e da orientadora) pelo período mínimo de cinco anos. Caso seja observado algum comportamento julgado antiético ou prejudicial, você tem o direito de expressar suas preocupações para o coordenador responsável pela pesquisa, através dos e-mails: manuelagrill_@hotmail.com e cynthiapaesdecarvalho@puc-rio.br ou telefone (21) 98212-6757, para que se 
tome as medidas julgadas necessárias. Assim como através do Câmara de Ética em Pesquisa da PUC-Rio", no endereço: Rua Marquês de São Vicente, 225, Prédio Kennedy $-2^{\circ}$ andar - Gávea - RJ.

Esperamos poder contar com a sua participação nessa pesquisa. Eu, (nome completo), da turma fui informado(a) dos objetivos do presente estudo de maneira clara e detalhada e esclareci minhas dúvidas. Sei que a qualquer momento poderei pedir novas informações, e que o meu responsável poderá mudar de ideia sobre minha participação nessa pesquisa. Declaro que concordo em participar da pesquisa e que recebi uma cópia desta carta.

Rio de Janeiro, de de 20

\section{Sobre a gravação de áudio:}

Não autorizo a gravação em áudio do que eu disser durante o estudo.

Autorizo a gravação em áudio do que eu disser durante o estudo.

Assinatura do Pesquisador

Manuela Grill Rodrigues
Assinatura do Participante

OBS.: Este termo é assinado em 2 vias, uma do/a voluntário/a e outra para os arquivos dos pesquisadores. 


\section{TERMO DE CONSENTIMENTO LIVRE E ESCLARECIDO| RESPONSÁVEIS}

Prezado/a responsável,

Viemos, por meio deste, pedir a autorização para que seu filho/sua filha participe da pesquisa apresentada a seguir.

Pesquisa: "Jovens e escolas: quais as relações?"

\section{Pesquisadores:}

Mestranda: Manuela Grill Rodrigues (email: manuelagrill_@hotmail.com / telefone: (98) 982049800)

Orientadora: Prof. ${ }^{a}$ Dr. $^{\text {a }}$ Cynthia Paes de Carvalho (email: cynthiapaesdecarvalho@puc-rio.br / telefone: (21) 98212-6757)

Justificativas: A literatura que aborda a relação entre juventude e escola revela a existência de conflitos que permeiam a participação do jovem dentro do ambiente escolar. Aliado a isso, os dados disponibilizados pelo Ministério da Educação (MEC) através do Índice de Desenvolvimento da Educação Básica (Ideb) apontam que o último ano do ensino fundamental $\left(9^{\circ}\right.$ ano) não consegue atingir a meta prevista para o país desde 2013, além de possuir altas taxas de abandono e evasão. Tendo em vista esse cenário, esta pesquisa pretende compreender como as diferentes juventudes enxergam suas respectivas escolas e o seu processo de escolarização. Pesquisas como essas contribuem para aprofundarmos o conhecimento sobre a relação dos jovens com a escola e, futuramente, pensarmos em políticas e ações que favoreçam a trajetória dos alunos no ambiente escolar.

\section{Objetivo:}

Compreender as relações que os jovens estabelecem com a escola ao longo do seu processo de escolarização

Metodologia: Os participantes da pesquisa serão jovens do $9^{\circ}$ ano de escolas públicas e particulares da cidade do Rio de Janeiro.

A proposta de metodologia pode ser dividida em 8 etapas: 1) Ampliação/consolidação da revisão bibliográfica; 2) Análise dos questionários já existentes que tratam da relação entre juventude e escola; 3) Produção do questionário; 4) Análise do questionário por especialistas; 5) Avaliação das escolas selecionadas; 6) Realização de um pré-teste assistido; 7) Aplicação do instrumento revisado; 8) Análise das respostas coletadas.

O seu consentimento está sendo solicitado apenas para a participação na $6^{\mathrm{a}}$ etapa da pesquisa, que será realizada na escola onde seu filho estuda, com mais 4 alunos do 
$9^{\circ}$ ano. Essa etapa contará com a aplicação de um questionário sobre as relações que os jovens estabelecem com a escola e seu processo de escolarização e entrevista sobre o questionário. Ambos serão realizados no horário determinado pela professora e diretora da escola. A entrevista será gravada em áudio para posterior análise. Garantimos a confidencialidade das gravações (apenas a autora e a orientadora da pesquisa terão acesso aos áudios) assim como indenização diante de eventuais danos provocados pela participação na pesquisa.

Riscos e Benefícios Não são previstos riscos físicos ou morais. No entanto, caso seu filho fique de alguma forma incomodado ou constrangido com a situação, conversaremos com ele sobre o ocorrido, sobre como ele se sente e falaremos um pouco mais sobre a pesquisa, até que ele se sinta realmente acolhido e confortável. Além disso, deixaremos claro que será permitido a sua desistência, sem nenhuma consequência. Os benefícios relacionam-se com o fato de o estudante, no momento de preenchimento do questionário, ter a oportunidade refletir sobre a sua relação com a sua escola e o seu nível de participação dentro deste estabelecimento, podendo expressar a sua opinião sobre diversos aspectos que permeiam a sua experiência escolar.

A qualquer momento, durante a pesquisa e até um ano após o seu término, você poderá solicitar mais informações sobre o estudo ou cópias dos materiais divulgados, entrando em contato através do e-mail: manuelagrill_@ hotmail.com ou através do telefone (98) 98204-9800. O material da pesquisa ficará sob a guarda da pesquisadora (e da orientadora) pelo período mínimo de cinco anos. Caso seja observado algum comportamento julgado antiético ou prejudicial, você tem o direito de expressar suas preocupações para o coordenador responsável pela pesquisa, através dos e-mails: manuelagrill_@hotmail.com e cynthiapaesdecarvalho@puc-rio.br ou telefone (21) 98212-6757, para que se tome as medidas julgadas necessárias. Assim como através do Câmara de Ética em Pesquisa da PUC-Rio", no endereço: Rua Marquês de São Vicente, 225, Prédio Kennedy $-2^{\circ}$ andar - Gávea - RJ.

$\mathrm{Eu}$,

, de maneira voluntária, livre e esclarecida, autorizo meu filho/minha

filha

(nome

completo), da turma __ da Escola

a participar desta pesquisa. Estou ciente

dos objetivos do estudo, dos procedimentos metodológicos, dos possíveis desconfortos com o tema, das garantias de confidencialidade e da possibilidade de esclarecimentos permanentes sobre os mesmos. Fui informado(a) de que se trata de pesquisa em andamento no Programa de Pós-Graduação em Educação da PUC-Rio. Estou de acordo com a vídeo-gravação da entrevista coletiva a ser cedida para fins de registros acadêmicos. Estou ciente de que, em qualquer fase da pesquisa, tenho a liberdade de recusar a minha autorização ou retirar meu consentimento, sem 
nenhuma penalização ou prejuízo que possam ser imputados ao meu filho/minha filha.

\section{Sobre a gravação de áudio:}

Não autorizo a gravação em áudio do que meu filho disser durante o estudo.

Autorizo a gravação em áudio do que meu filho disser durante o estudo.

Manuela Grill Rodrigues, Mestranda.

[assinatura do/a responsável]

Nome

completo

E-mail: Identificação (RG): Tel.

Janeiro, de de 2020 .

OBS.: Este termo é assinado em 2 vias, uma do/a responsável e outra para os arquivos dos pesquisadores. 


\section{SEÇÃO E- TERMOS DE ASSENTIMENTO E CONSENTIMENTO - QUESTIONÁRIO}

PONTIFÍCIA UNIVERSIDADE CATÓLICA DO RIO DE JANEIRO Programa de Pós-Graduação em Educação

PUC

\section{TERMO DE CONSENTIMENTO LIVRE E ESCLARECIDO | PAIS E RESPONSÁVEIS}

Prezado/a responsável,

Viemos, por meio deste, pedir a autorização para que seu filho/sua filha participe da pesquisa apresentada a seguir.

Pesquisa: "Jovens e escolas: quais as relações?"

\section{Pesquisadores:}

Mestranda: Manuela Grill Rodrigues (email: manuelagrill_@hotmail.com / telefone: 98-982049800)

Orientadora: Prof. $^{\text {a }}$ Dr. $^{\text {a }}$ Cynthia Paes de Carvalho (email: cynthiapaesdecarvalho@ puc-rio.br / telefone: 98212-6757)

Justificativas: A literatura que aborda a relação entre juventude e escola revela a existência de conflitos que permeiam a participação do jovem dentro do ambiente escolar. Aliado a isso, os dados disponibilizados pelo Ministério da Educação (MEC) através do Índice de Desenvolvimento da Educação Básica (Ideb) apontam que o último ano do ensino fundamental $\left(9^{\circ}\right.$ ano) não consegue atingir a meta prevista para o país desde 2013, além de possuir altas taxas de abandono e evasão. Tendo em vista esse cenário, esta pesquisa pretende compreender como as diferentes juventudes enxergam suas respectivas escolas e o seu processo de escolarização. Pesquisas como essas contribuem para aprofundarmos o conhecimento sobre a relação dos jovens com a escola e, futuramente, pesarmos em políticas e ações que favoreçam a trajetória dos alunos no ambiente escolar.

\section{Objetivo:}

Compreender as relações que os jovens estabelecem com a escola e seu processo de escolarização

Metodologia: Os participantes da pesquisa serão jovens do $9^{\circ}$ ano de escolas públicas e particulares da cidade do Rio de Janeiro.

A proposta de metodologia pode ser dividida em 8 etapas: 1) Ampliação/consolidação da revisão bibliográfica; 2) Análise dos questionários já existentes que tratam da relação entre juventude e escola; 3) Produção de um novo questionário; 4) Análise do questionário por especialistas; 5) Análise das escolas selecionada; 6) Realização de um pré-teste assistido; 7) Aplicação do instrumento construído; 8) Análise das respostas coletadas. 
O seu consentimento está sendo solicitado apenas para a participação na $7^{\mathrm{a}}$ etapa da pesquisa, que será realizada na escola onde seu filho estuda. Essa etapa contará com a aplicação de um questionário sobre a relação que os jovens estabelecem com a escola e seu processo de escolarização. A aplicação será realizada no horário determinado pela professora e diretora da escola. Garantimos a confidencialidade das respostas (apenas a autora e a orientadora da pesquisa terão acesso aos áudios) assim como indenização diante de eventuais danos provocados pela participação na pesquisa.

Riscos e Benefícios Não são previstos riscos físicos ou morais. No entanto, caso seu filho fique de alguma forma incomodado ou constrangido com a situação, conversaremos com ele sobre o ocorrido, sobre como ele se sente e falaremos um pouco mais sobre a pesquisa, até que ele se sinta realmente acolhido e confortável. Além disso, deixaremos claro que será permitido a sua desistência, sem nenhuma consequência. Os benefícios relacionam-se com o fato de o estudante, no momento de preenchimento do questionário, ter a oportunidade refletir sobre a sua relação com a sua escola e o seu nível de participação dentro deste estabelecimento, podendo expressar a sua opinião sobre diversos aspectos que permeiam a sua experiência escolar.

A qualquer momento, durante a pesquisa e até um ano após o seu término, você poderá solicitar mais informações sobre o estudo ou cópias dos materiais divulgados, entrando em contato através do e-mail: manuelagrill_@hotmail.com ou através do telefone (98) 98204-9800. O material da pesquisa ficará sob a guarda da pesquisadora (e da orientadora) pelo período mínimo de cinco anos. Caso seja observado algum comportamento julgado antiético ou prejudicial, você tem o direito de expressar suas preocupações para o coordenador responsável pela pesquisa, através dos e-mails: manuelagrill_@hotmail.com e cynthiapaesdecarvalho@puc-rio.br ou telefone (21) 98212-6757, para que se tome as medidas julgadas necessárias. Assim como através do Câmara de Ética em Pesquisa da PUC-Rio", no endereço: Rua Marquês de São Vicente, 225, Prédio Kennedy $-2^{\circ}$ andar - Gávea - RJ.

$\mathrm{Eu}$,

, de maneira voluntária, livre e esclarecida, autorizo meu filho/minha

filha

(nome

completo), da turma __ da Escola

a participar desta pesquisa. Estou ciente

dos objetivos do estudo, dos procedimentos metodológicos, dos possíveis desconfortos com o tema, das garantias de confidencialidade e da possibilidade de esclarecimentos permanentes sobre os mesmos. Fui informado(a) de que se trata de pesquisa em andamento no Programa de Pós-Graduação em Educação da PUC-Rio. Estou de acordo com a vídeo-gravação da entrevista coletiva a ser cedida para fins de registros acadêmicos. Estou ciente de que, em qualquer fase da pesquisa, tenho a liberdade de recusar a minha autorização ou retirar meu consentimento, sem 
nenhuma penalização ou prejuízo que possam ser imputados ao meu filho/minha filha.

Manuela Grill Rodrigues, mestranda.

[assinatura do/a responsável]

Nome

completo:

E-mail: Tel.

Identificação (RG):

de 2020.

| Rio de Janeiro, de

OBS.: Este termo é assinado em 2 vias, uma do/a responsável e outra para os arquivos dos pesquisadores. 


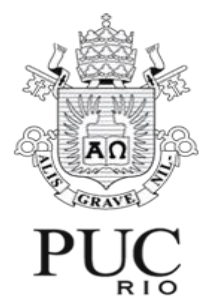

\section{TERMO DE ASSENTIMENTO LIVRE E ESCLARECIDO}

Prezado, aluno (a).

Você está sendo convidado(a) como voluntário(a) a participar da pesquisa "Jovens e escolas: quais as relações?"

Neste estudo pretendemos compreender as relações que os jovens estabelecem com a escola e o seu processo de escolarização.

Sua colaboração será necessária na $7^{\mathrm{a}}$ etapa dessa pesquisa, quando aplicaremos um questionário que aborda questões acerca da sua escola (sua percepção sobre a instituição, como avalia alguns aspectos desse estabelecimento, qual o nível participação discente, entre outros), sua trajetória escolar (com quantos anos entrou na escola, quais espaços utiliza nesse estabelecimento etc.) e sobre seus hábitos enquanto jovem (o que gosta de fazer, se faz parte de algum coletivo, entre outros). A aplicação do questionário será feita na sua escola, com a autorização da sua professora e dos seus pais, terá a minha presença e de mais uma pesquisadora. $\mathrm{O}$ questionário será respondido individualmente.

A qualquer momento, você poderá tirar dúvidas ou encerrar sua participação na pesquisa. Caso você se sinta incomodado ou envergonhado durante a atividade, peço que fale comigo para que possamos te ajudar. No entanto, achamos que essa será uma experiência interessante, já que você terá espaço para refletir e dar a sua opinião sobre a sua participação dentro da sua escola.

Lembramos que a sua colaboração é voluntária e se você não quiser participar, não terá nenhuma consequência em casa ou na escola.

Garantimos que sua identidade não será revelada a ninguém e que somente nós, pesquisadores, teremos acesso às respostas do questionário.

Além disso, durante a pesquisa e até um ano após o seu término, você poderá solicitar mais informações sobre o estudo ou cópias dos materiais divulgados, entrando em contato através do e-mail: manuelagrill_@hotmail.com ou através do telefone (98) 98204-9800. O material da pesquisa ficará sob a guarda da pesquisadora (e da orientadora) pelo período mínimo de cinco anos. Caso seja observado algum comportamento julgado antiético ou prejudicial, você tem o direito de expressar suas preocupações para o coordenador responsável pela pesquisa, através dos e-mails: manuelagrill_@hotmail.com e cynthiapaesdecarvalho@puc-rio.br ou telefone (21) 98212-6757, para que se tome as medidas julgadas necessárias. Assim como através do Câmara de Ética em Pesquisa da PUC-Rio", no endereço: Rua Marquês de São Vicente, 225, Prédio Kennedy $-2^{\circ}$ andar - Gávea - RJ.

Esperamos poder contar com a sua participação nessa pesquisa. Eu, (nome completo), da turma da Escola fui informado(a) dos objetivos do presente estudo de maneira clara e detalhada e esclareci minhas dúvidas. Sei que a qualquer momento poderei pedir novas informações, e que o meu 
responsável poderá mudar de ideia sobre minha participação nessa pesquisa. Declaro que concordo em participar da pesquisa e que recebi uma cópia desta carta.

Rio de Janeiro,

de de 20
Assinatura do Participante
Assinatura do Pesquisador

Manuela Grill Rodrigues
OBS.: Este termo é assinado em 2 vias, uma do/a responsável e outra para 